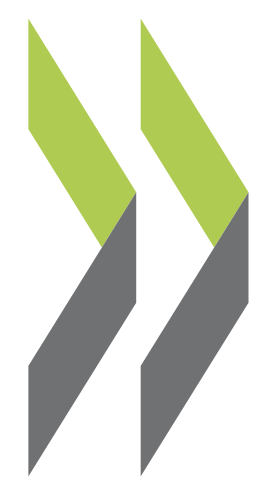

OECD Economics Department Working Papers No. 769

Health Care Systems: Efficiency and Institutions
Isabelle Joumard,

Christophe André,

Chantal Nicq 
Organisation de Coopération et de Développement Économiques

Organisation for Economic Co-operation and Development

19-May-2010

ECONOMICS DEPARTMENT

English - Or. English

HEALTH CARE SYSTEMS: EFFICIENCY AND INSTITUTIONS

ECONOMICS DEPARTMENT WORKING PAPERS No. 769

by Isabelle Joumard, Christophe André and Chantal Nicq

All Economics Department Working Papers are available through OECD's Internet website at www.oecd.org/eco/Workingpapers

JT03283813

Document complet disponible sur OLIS dans son format d'origine

Complete document available on OLIS in its original format 


\section{ABSTRACT/RÉSUMÉ \\ Health care systems: efficiency and institutions}

This paper presents a set of indicators to assess health care system performance. It also presents new comparative data on health care policies and institutions for OECD countries. This set of indicators allows the empirical characterisation of health care systems and the identification of groups of countries sharing similar health institutions. It also helps to uncover strengths and weaknesses of each country's health care system and assessing the scope for improving value-for-money. The empirical analysis suggests that there is room in all countries surveyed to improve the effectiveness of health care spending; there is no health care system that performs systematically better in delivering cost-effective health care big-bang reforms are therefore not warranted; increasing the coherence of policy settings, by adopting best policy practices within a similar system and borrowing the most appropriate elements from other systems will likely be more practical and effective to raise health care spending efficiency.

JEL classification codes: I11; I12; I18; H51; H21

Key words: health care system; efficiency; public spending; health institutions and policies

$* * * * * * * *$

\section{Systèmes de santé : efficacité et institutions}

Ce document présente un ensemble d'indicateurs afin d'évaluer la performance des systèmes de santé. Il présente aussi de nouvelles données comparatives sur les politiques et les institutions dans le domaine de la santé pour les différents pays de l'OCDE. Cet ensemble d'indicateurs permet de caractériser empiriquement les systèmes de santé en identifiant des groupes de pays ayant des politiques et institutions comparables. Il permet aussi de mettre en valeur les forces et les faiblesses du système de santé de chaque pays et de déterminer les gains potentiels d'efficacité. L'analyse empirique montre que dans chacun des pays étudiés l'efficacité des dépenses de santé peut être améliorée; qu'il n'existe pas de système qui, pour un coût donné, produit systématiquement des meilleurs résultats - des réformes radicales en faveur d'un système de santé ne sont donc pas nécessaires ; accroitre la cohérence des politiques en matière de santé en adoptant les politiques les plus performantes à l'intérieur d'un système similaire et en empruntant les éléments les plus appropriés aux autres systèmes s'avérera vraisemblablement plus réaliste et plus efficace pour améliorer l'efficacité de la dépense en matière de santé.

Classification JEL : I11 ; I12 ; I18 ; H51 ; H21

Mots-clés : système de santé ; efficacité ; dépense publique ; institutions et politiques de santé

Copyright OECD, 2010

Application for permission to reproduce or translate all, or part of, this material should be made to: Head of Publications Service, OECD, rue André Pascal, 75775 Paris CEDEX 16, France. 


\section{TABLE OF CONTENTS}

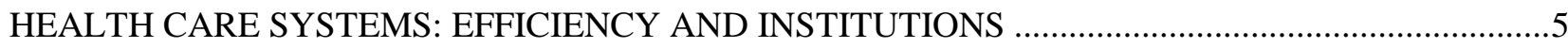

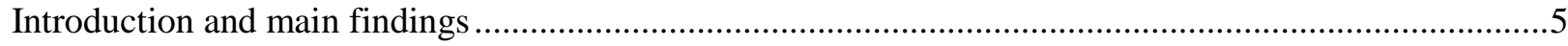

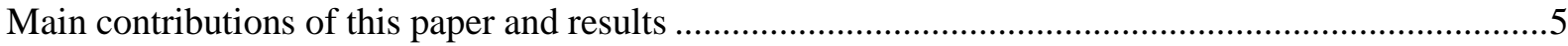

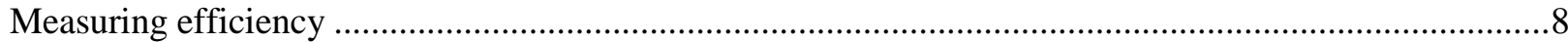

The objectives against which performance will be measured ..............................................................10

Adopting an outcome and system-level approach to measure performance …….................................12

Deriving outcome efficiency measures for health care systems ......................................................15

Complementing aggregate efficiency indicators by "intermediate" performance indicators.................19

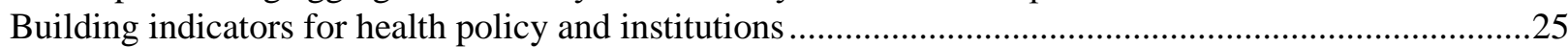

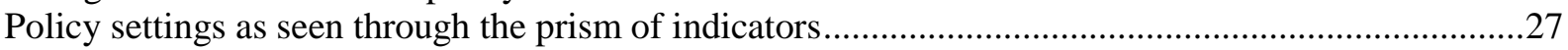

Steering the demand and supply of health care: indicators on market mechanisms and regulations .....27

Mitigating inequalities in health care access: indicators on health care coverage .................................37

Containing public spending: indicators on budget and management approaches ................................39

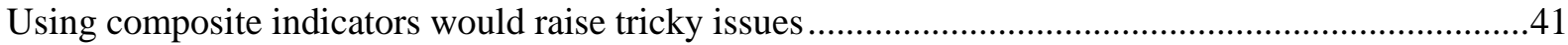

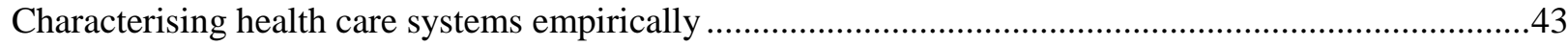

Identifying institutional patterns using principal component analysis ..............................................45

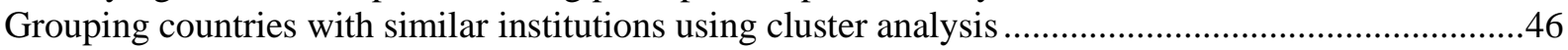

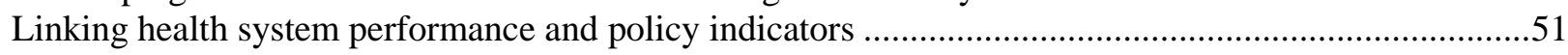

Efficiency across and within groups of countries sharing similar institutional characteristics ...............51

Drawing comparisons and identifying weaknesses from a "within-group" analysis .............................53

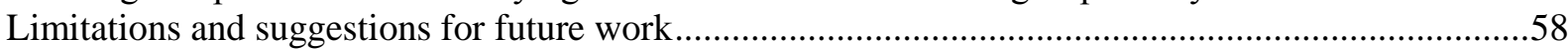

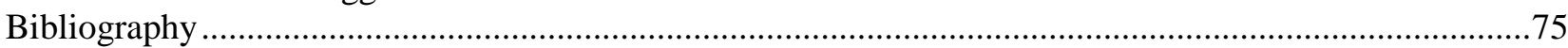

Annex 1. The World Health Organisation study on the effectiveness of health care systems ......................81

Annex 2. Additional information on health care outcomes, spending and efficiency .................................83

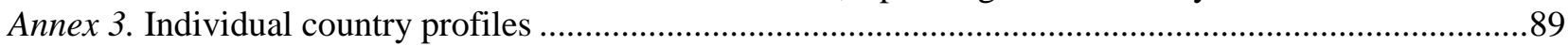

Annex 4. Market failures and imperfections in health care systems and government interventions ...........122

Annex 5. Principal component and cluster analysis............................................................................... 125

Annex 6. Principal component analysis on budget and management approaches to control public

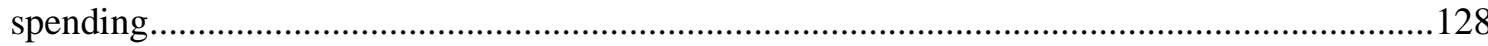

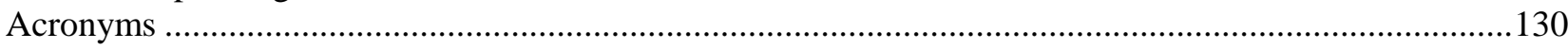

\section{Boxes}

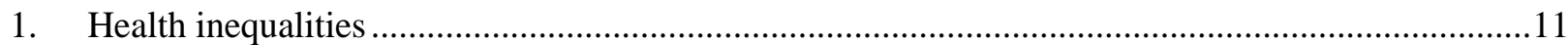

2. Health care outcome data: amenable mortality and health care quality .........................................16

3. Health care systems: a wide variety of frameworks and the OECD typology .................................44

\section{Tables}

1. Groups of countries sharing broadly similar institutions.............................................................

2. Contributions of main explanatory variables to changes in health status ........................................17

3. Contributions of main explanatory variables to cross-country differences in life expectancy at birth ...... 
4. Overview of the indicators on health policies and institutions

5. Reliance on market mechanisms and regulations to steer the demand and supply of health care:

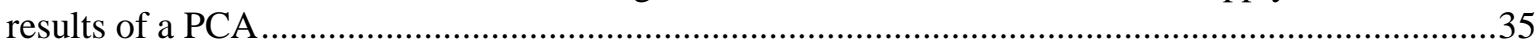

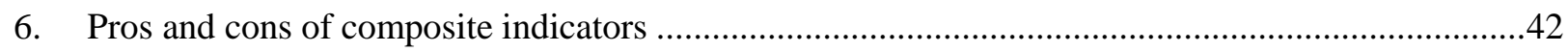

7. Results of a PCA on the full set of indicators on health policy and institutions .............................45

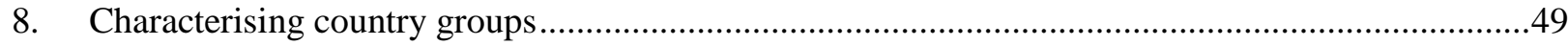

9. DEA efficiency scores: means and variances within and across country groups ............................52

10. Main characteristics emerging from within-group comparisons .....................................................60

\section{Figures}

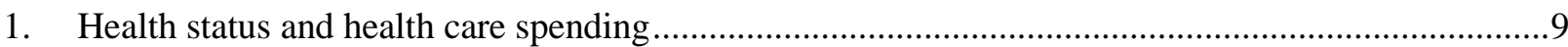

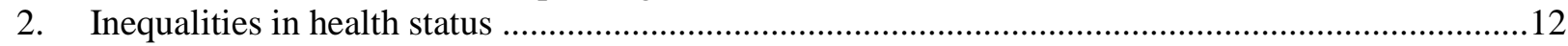

3. From health care inputs to outputs and outcomes ........................................................................13

4. Amenable mortality: international comparison using two different lists .....................................16

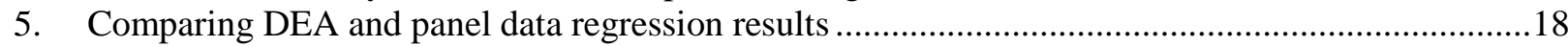

6. DEA efficiency scores are fairly robust to changes in specification .............................................20

7. International comparisons based on a selection of efficiency measures based on outputs................22

8. International comparisons based on a selection of health care quality indicators ..........................26

9. The tree structure for the indicators on health policies and institutions ........................................28

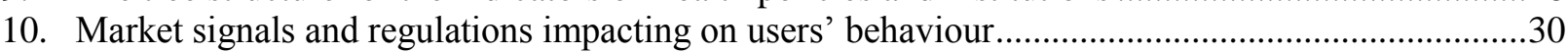

11. Market signals and regulations impacting on providers' behaviour................................................3

12. Market signals and regulations impacting on insurers' behaviour .................................................34

13. Reliance on market mechanisms and regulations to steer the demand and supply of health care......36

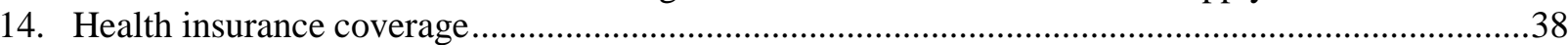

15. Budget and management approaches - Setting and sharing the spending envelope ..........................39

16. Budget and management approaches - Decentralisation and delegation ..........................................41

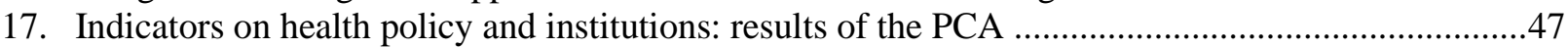

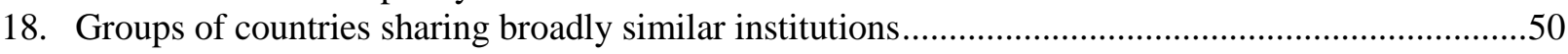

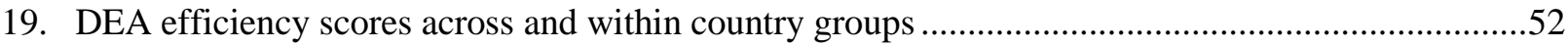

20. Health outcomes and spending levels across and within country groups ........................................54

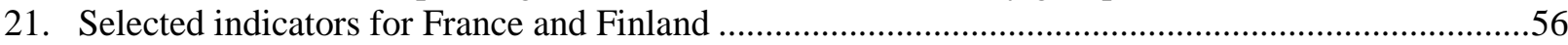


ECO/WKP(2010)25

\title{
HEALTH CARE SYSTEMS: EFFICIENCY AND INSTITUTIONS
}

\author{
By Isabelle Joumard, Christophe André and Chantal Nicq ${ }^{1}$
}

\section{Introduction and main findings}

1. A key policy challenge in most OECD countries is to improve outcomes of the health care system while containing cost pressures. The recent economic and financial crisis has weighed heavily on fiscal positions - with gross government debt projected to exceed 100\% of GDP in the OECD area by 2011 - and reinforced the need to improve public spending efficiency. Public spending on health care is one of the largest government spending items, representing on average 6\% of GDP. Furthermore, health care costs are rising rapidly, driven by population ageing, rising relative prices and costly developments in medical technology. Public health care spending is projected to increase by 3.5 to 6 percentage points of GDP by 2050 in the OECD area. Against this background, exploiting efficiency gains in health care will be crucial to meet rapidly growing health care demand, without putting the public finances on an unsustainable path.

2. The first section of this paper presents an approach to derive cross-country comparisons of health care spending efficiency, based on health care outcomes measured at a system level. It updates and upgrades results presented in Joumard et al. (2008) and complements these outcome-based efficiency estimates with output-based efficiency indicators for hospitals and indicators on the quality of preventive and out-patient care. The second section provides a brief overview of the main health policy instruments and institutional features which may affect health care system efficiency and presents corresponding indicators built on the basis of a questionnaire completed by 29 OECD countries (Paris et al., 2010). ${ }^{2}$ The third section identifies how different aspects of health policies are combined within countries and characterises a number of health care models. The last section investigates the links between policy settings and health care system efficiency.

\section{Main contributions of this paper and results}

\section{Measuring performance: efficiency estimates and their link with other performance indicators}

3. One way of gauging the efficiency of health care spending is by estimating the contribution of health care spending to life expectancy, taking into account lifestyle and socio-economic factors. Indeed, life expectancy has increased by more than one year every four years on average since the early 1990s. True, it is only a partial indicator since it does not reflect morbidity or the quality of life. Nevertheless, life

1. The authors are greatly indebted to Peter Hoeller who supervised this work, to Thai-Thanh Dang, Marion Devaux and Lihan Wei for their help in building health indicators, to Jørgen Elmeskov, Howard Oxley, Valérie Paris, Mark Pearson, Jean-Luc Schneider and other colleagues for their useful comments, to Susan Gascard for excellent secretarial assistance and to some health professionals who are doing an outstanding, though difficult, job, for their advice.

2. As of April 2010, the United States had not responded to this questionnaire. 
expectancy is highly correlated with other indicators of health status. Furthermore, the impact of changes in lifestyles and socio-economic factors on life expectancy can be accounted for. Estimates for health care spending efficiency have been derived using two different methods - panel data regressions and data envelopment analysis (DEA) - and different assumptions and the results are robust. They suggest that:

- Life expectancy at birth could be raised by more than two years on average, holding health care spending constant, if all countries were to become as efficient as the best performers. By way of comparison, a $10 \%$ increase in health care spending would increase life expectancy by only three to four months if the extent of inefficiency remained unchanged. Despite the limitations inherent in macro-level approaches, results from panel regressions and DEA are rather similar and robust to changes in specification.

- Although estimates of health care spending efficiency should not be taken at face value, they suggest that Australia, Korea, Japan and Switzerland perform best in transforming money into health outcomes. Margins for improving outcomes while keeping spending constant are the largest in Denmark, Hungary, the Slovak Republic and the United States.

- There is generally no trade-off between efficiency and equity in health status. Data would even signal a weak complementarity: the countries with the lowest inequalities in health status also tend to enjoy the highest average health status.

- Correlations between overall system (outcome-based) efficiency estimates and (output-based) efficiency indicators often used for hospitals (e.g. average length of stays and occupancy rate for hospital acute care beds) are very low. This suggests that medical outputs can be produced very efficiently in one sub-sector but still have only a limited impact on the population health status, or that high performance in the in-patient care sector is offset by inefficiencies in other sub-sectors of the health care system or that co-ordination problems exist across sub-sectors.

- Estimates of overall system efficiency are better correlated with quality of care indicators (such as avoidable admission rates in the in-patient care sector), even though the quality of care indicators still do not have wide coverage to make solid cross-country comparisons.

\section{Building indicators for health policies and institutions}

4. To assess the influence of health policies and institutions on health care system efficiency, a unique set of information on health policies and institutions has been gathered from OECD countries - the United States was the only country which did not respond to the survey. This dataset covers incentives and regulations affecting the behaviour of producers, users and insurers, insurance coverage as well as the degree of decentralisation and approaches to contain spending. It reveals that:

- The basic insurance coverage - measured by the population covered, services included and the degree of cost-sharing - is substantial and fairly similar across OECD countries. Mexico, Turkey and the United States are the exceptions, with still a large share of the population not covered in 2009 .

- Some OECD countries rely heavily on centralised command-and-control systems to steer the demand and supply of health care services while in a few countries regulated market mechanisms, such as fee-for-services, competition driven by user choice and private insurance, play a dominant role. But more and more countries rely on a mix of the two. 
- While market-based and regulatory approaches are often presented as two distinct models, in practice incentives and regulations are more often combined than used in isolation.

- Some policy levers tend to be implemented simultaneously, signalling potential complementarities across them. For example, those countries relying extensively on private providers to deliver health care services also tend to implement activity-based compensation schemes for providers and offer users a choice among providers.

- In contrast, some policy instruments are used independently of the other regulatory and market features. The degree of reliance on out-of-pocket payments provides an example. This suggests that, when setting user fees, political economy, fiscal and equity considerations play a greater role than willingness to ensure consistency in policy settings.

\section{Identifying health care models}

5. A key contribution of this paper is to provide an empirical characterisation of health care systems, which goes beyond classifications based on a few institutional features and recognises the complexity of health institutions and complementarities across them.

- Using cluster analysis, six groups of countries sharing broadly similar institutions have been identified (Table 1): one group of countries relies extensively on market mechanisms in regulating both insurance coverage and service provision; two groups are characterised by public basic insurance coverage and extensive market mechanisms in regulating provision, but differentiated by the use of gate-keeping arrangements and the degree of reliance on private health insurance to cover expenses beyond the basic package; a group where the rules provide patients with choice among providers, with no gate-keeping but extremely limited private supply; and two groups of heavily regulated public systems, separated by differing degrees of the stringency of gate-keeping arrangements and of the budget constraint. Sensitivity analysis shows that the clusters identified are fairly robust.

Table 1. Groups of countries sharing broadly similar institutions

\begin{tabular}{l|l}
\hline Group 1 & Germany, Netherlands, Slovak Republic, Switzerland \\
Group 2 & Australia, Belgium, Canada, France \\
Group 3 & Austria, Czech Republic, Greece, Japan, Korea, Luxembourg \\
Group 4 & Iceland, Sweden, Turkey \\
Group 5 & Denmark, Finland, Mexico, Portugal, Spain \\
Group 6 & Hungary, Ireland, Italy, New Zealand, Norway, Poland, United Kingdom \\
\hline
\end{tabular}

\section{Linking efficiency and policies}

6. Efficiency estimates vary more within country groups sharing similar institutional characteristics than between groups. This suggests that no broad type of health care system performs systematically better than another in improving the population health status in a cost-effective manner. Still, within-group comparisons allow the spotting of strengths and weaknesses for each country and identifying areas where achieving greater consistency in policy settings could yield efficiency gains. Key results are as follows:

- Some suggestions for policy reform apply to many countries, independently of their group. In particular, better priority setting, improved consistency of responsibility assignment across levels of government, better user information on quality and prices of health care services and better 
balanced provider payment schemes would be reform options to consider in many OECD countries.

- For some policy instruments, a "one-size-fits-all" approach to reform is not advisable as increasing consistency in policy settings entails implementing different, and even seemingly opposite, approaches. As an example, regulations concerning the hospital workforce and equipment may need to be softened in some countries and hardened in others.

- Administrative costs tend to be higher in most of those countries relying on market mechanisms to deliver a basic insurance package (Germany, Netherlands and Switzerland). However, they also exceed the average level by a considerable margin in a few others (Belgium, France, Luxembourg, Mexico and New Zealand), signalling a potential for reducing spending.

- Inequalities in health status tend to be lower in three of the four countries with a private insurance-based system - Germany, Netherlands and Switzerland-, indicating that regulation and equalisation schemes can help mitigating cream-skimming and the effects of other market mechanisms which can raise equity concerns.

\section{Measuring efficiency}

7. Health care spending has continued to increase in all OECD countries over the past decade, despite the many measures to restrain it (Figure 1, Panel A). In 2007, total spending on health care absorbed about 9\% of GDP on average in the OECD. The cross-country variation is wide, however, ranging from less than $6 \%$ in Mexico and Turkey to $16 \%$ in the United States. ${ }^{3}$ Health care spending is projected to continue to rise swiftly, driven by technological and income developments, as well as demographic factors (Oliveira Martins and de la Maisonneuve, 2006). Against this background, improving value for money in the health care sector is an important objective in many OECD countries.

8. The increase in health care spending has been accompanied by improvements in the population health status (Figure 1, Panel B). Still, the countries that spend most are not necessarily the ones that fare best in terms of health status indicators and quality of care, which suggests that there is scope to improve the cost-effectiveness of spending in many countries (Figure 1, Panel C).

9. The main objective of this section is to provide cross-country comparisons of health care system efficiency. It first reviews policy objectives, specifies the objectives against which performance will be measured and provides the reasons for choosing an outcome and system-level approach to measure performance, rather than an output, sub-sector or disease-based approach. It then describes the methodology to derive efficiency measures - by relating health care outcomes to total (public and private) health care resources while controlling for socio-economic, lifestyle and environmental variables - and presents efficiency estimates for all OECD countries. These efficiency measures are complemented by more specific, but partial, efficiency indicators based on health care outputs and by indicators of the quality of health care services (mainly out-patient and preventive care) that can help in identifying policy recommendations. ${ }^{4}$

3. Spending on long-term care is included in total health care spending.

4. While this paper assesses whether resources devoted to the health care system are spent efficiently, it does not assess whether more money should be spent to increase the population health status and, if so, how public money should be allocated across different public spending programmes (health care, education, infrastructure, etc.). These issues largely hinge on societal preferences. 
Figure 1. Health status and health care spending

Panel A. Increase in health spending per capita in real terms, 1995-2007

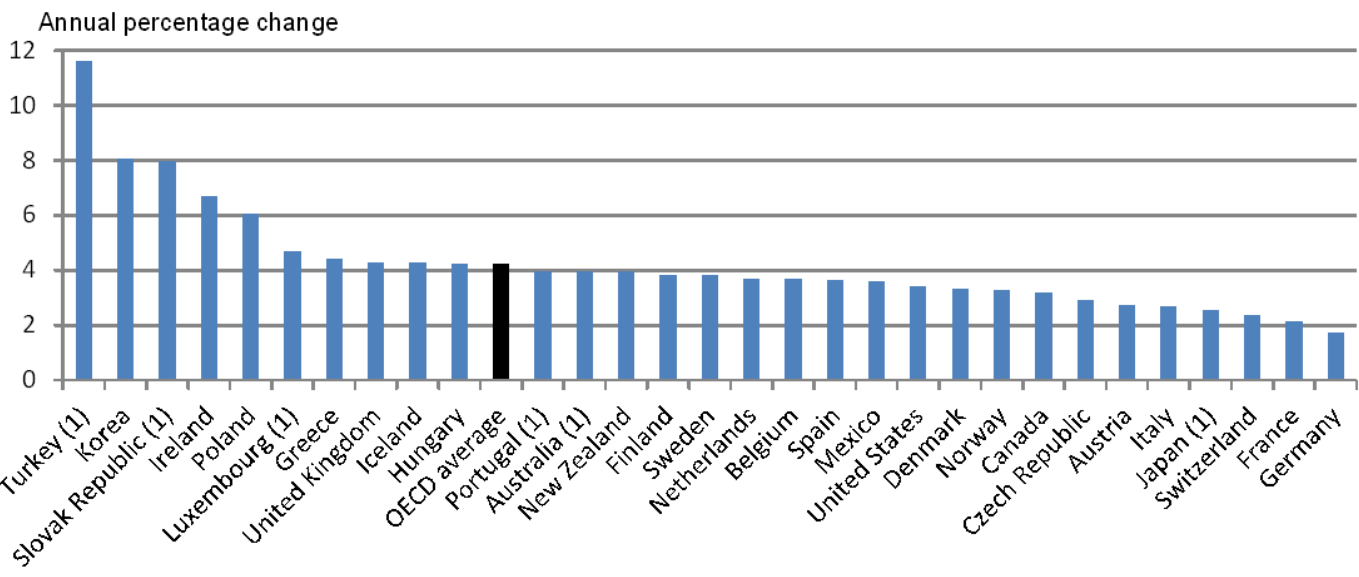

Panel B. Gains in life expectancy at birth, 1995-2007

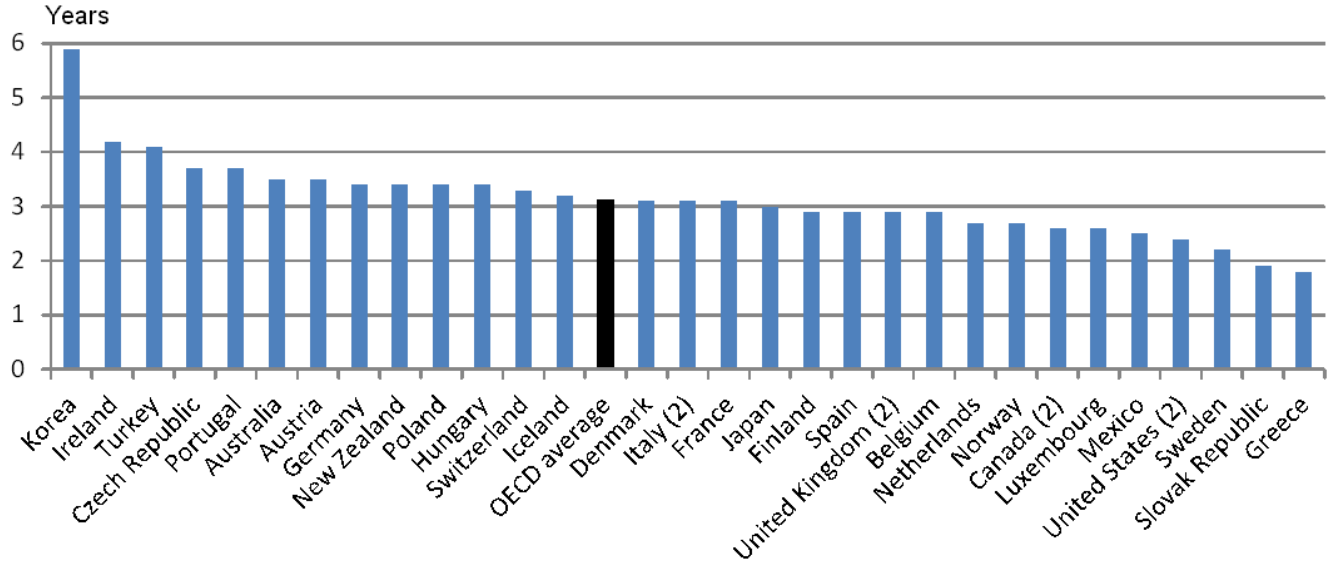

Panel C. Large differences in health status and spending across OECD countries persist, $2007^{3}$

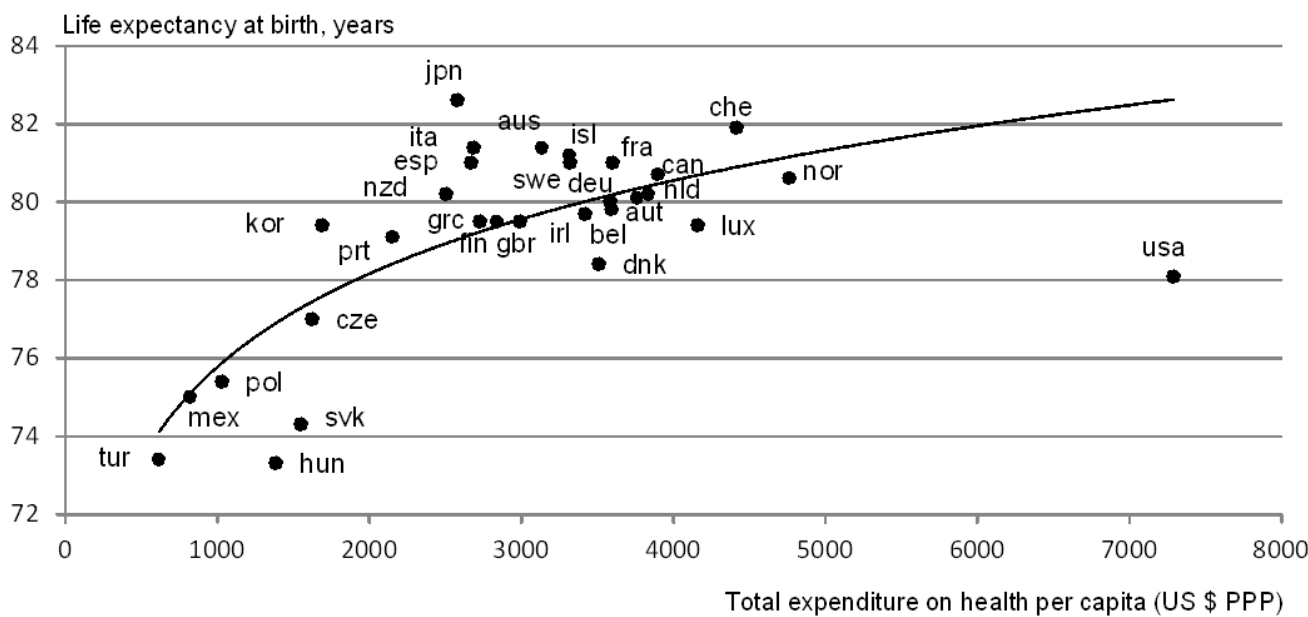

1. 1995-2005 for Turkey; 1995-2006 for Australia, Japan, Luxembourg and Portugal; 1997-2007 for the Slovak Republic. 


\section{The objectives against which performance will be measured}

10. OECD governments pursue many health care objectives, including: health care acceptability, accessibility, effectiveness, (cost) efficiency, equity, public satisfaction, quality of treatment, responsiveness to individuals' preferences, safety, sustainability and timeliness. ${ }^{5}$ Although all these are important and legitimate goals, their fulfilment is not always easy to measure and some of them are closely related. Furthermore, some of these objectives, such as accessibility, are a means to an end and are intermediate rather than final goals (WHO, 2000).

11. This paper focuses on two main objectives - raising the health status of the population and improving equity in access. Achieving these objectives critically depends on the available health care resources. However, there are limits to the resources that can be deployed as these objectives are pursued under a budget constraint: governments need to contain public spending on health care so as to avoid crowding out other public spending or raising taxes. Still, countries may not place the same relative weight on each of these objectives. And constraints and priorities may have changed over time (Cutler, 2002; Diderichsen, 1995). Most countries first focused on improving equity in access, creating National Health Services or social security systems, often in the aftermath of the Second World War. This has served to raise financial protection. In the 1970s and up to the 1990s, cost containment gained importance as health care costs were increasing rapidly, and many countries opted for restraining public spending on health care, often via regulations. Since the 1990s, many governments have progressively turned away from relying on rationing and price controls to adopt incentive-based reforms, with the objective of steering demand and supply for health care services better and thus improving micro-efficiency. In particular, countries have often increased cost-sharing to curb demand, reformed compensation systems for providers so as to boost productivity and some have raised competition at the provider level and/or at the level of insurers. In some cases, however, reforms that have sharpened incentives to provide high-quality services have made it more difficult to control public spending on health. ${ }^{6}$

12. While equity aspects are very important in policy-making, incorporating this dimension fully into the analysis is challenging. The lack of comparable cross-country data on equity in access is a main constraint. Some proxies for inequality in health status can be built for a majority, though not all, OECD countries (Box 1). They suggest that there are no obvious trade-offs between objectives. Those countries that have a better health status of the population also tend to have low health inequalities. ${ }^{7}$ Also, work carried out recently by the OECD concludes that socio-economic factors often play a key role in shaping inequality in health status. Further arguing against the direct inclusion of the equity dimension into the

5. Kelley and Hurst (2006) provide details on most of these dimensions and their definition across four OECD countries and three international organisations. As an illustration, "acceptability" is defined as "conformity to the realistic wishes, desires and expectations of health care users and their families. Since a person's health care experiences have a powerful effect on their future utilisation of and response to health care, responsiveness or patient-centeredness and acceptability are fundamental dimensions to effectiveness and other dimensions."

6. As an illustration, activity-based payment systems for providers (such as case-mix systems for hospitals and fee-for-services for physicians) are widely recognised to boost productivity and increase responsiveness to patient needs - they have often contributed to reduce waiting times for elective surgeries. However, they imply a loss of control over activity, and hence total public spending. In Sweden, activitybased funding introduced in the 1990s raised output significantly, helping to reduce waiting lists. The rise in output, however, led to budget over-runs. Stockholm County responded by imposing budget caps and cutting DRG prices while most other counties have also capped spending (OECD, 2005c; Diderichsen, 1995).

7. It should be recognised, however, that some policy levers may entail a trade-off when taken individually. In particular, deciding upon the appropriate level of user charges is not easy (Smith, 2008b). 
assessment of health care system performance are the difficulties arising when aggregating multiple objectives. ${ }^{8}$

\section{Box 1. Health inequalities}

Equity is often a key policy objective and this is also the case in health policy. This box reviews existing data on health inequalities, their limitations as well as their relevance and potential for incorporating health inequalities into the framework for assessing health system performance. ${ }^{1}$

Inequalities in health status: no apparent trade-off with the average health status of the population

Health inequalities can be proxied by the dispersion in the age of death among individuals (Edwards and Tuljapurkar, 2005; OECD, 2006c). ${ }^{2}$ Simplicity and the availability of data for most (26) OECD countries are the main advantages of this indicator. One key drawback is that this indicator fails to reflect inequalities in morbidity. Data on the dispersion in longevity indicators adjusted for morbidity or disability (DALE, DFLE and HALE) are however not available on a consistent basis for many OECD countries.

In 2006, the dispersion in the age of death was highest in the United States, followed by Hungary and Poland, and lowest in the Netherlands, Sweden and Iceland. Figure 2 (Panel A) suggests that there is no trade-off between increasing the average health status of the population (as measured by life expectancy at birth) and reducing the dispersion in health status (health inequalities). There may even be complementarity. ${ }^{3}$ This would be consistent with declining returns to scale of health care spending: concentrating spending on a small population group yields lower additional years of life for society than having a more equitable distribution of spending. Not covering part of the population with health insurance could lead to that group suffering from severe health problems which may eventually be treated, but at a high cost.

Inequalities in health status: partial evidence suggests that the health system does not play the key role

Most OECD countries have achieved nearly universal coverage of the population for a core basket of health goods and services, thus mitigating inequality in access. Inequality in access may still originate from differences in availability of medical resources across regions. The very weak correlation, if any, between the dispersion in ageadjusted mortality rates and in the number of practicing physicians per capita across regions (Figure 2, Panel B) suggests that inequality in access plays a minor role in explaining inequalities in health status.

Rather than the health care system, socio-economic factors are important in shaping inequalities in health status. Many studies conclude that those with a lower income, less education or employment in a less prestigious occupation tend to have a higher prevalence of illness and die at a younger age. Health inequality measures focusing on socioeconomic disadvantages have been developed in some countries. Still, gathering comparable data is difficult since, in many countries, mortality registries collect little or no information that can be used to determine the socio-economic background (De Looper and Lafortune, 2009). Indicators of socio-economic inequalities in health status and health care access that could easily be gathered regularly by the OECD are those for self-rated health status, self-rated disability and measures of unmet care needs. There are serious limitations, however, in using self-reported health status measures in cross-country comparisons.

Overall, the available data suggest that inequalities in health status differ significantly across countries. However, there is no obvious trade-off between raising the average health status of the population and improving equity, though the scarcity of available indicators makes it difficult to draw a definitive conclusion. The health care literature further concludes that health inequalities are largely driven by socio-economic factors and thus determined outside the health care sector.

1. Health inequalities or disparities can be defined as the apparent differences in health status (i.e. mortality/longevity and the prevalence of morbidity). Health inequities are defined as those health inequalities which are avoidable and are considered to be "unfair" according to some social norm (which may vary across countries).

2. The dispersion in the age at death is measured as the standard deviation of all deaths above the age of 10 for each age bracket, weighted by the number of observed deaths in each age bracket.

3. In the education sector also, those countries with the highest average PISA scores - measuring 15-year old pupils' aptitudes tend to be characterised by low disparities in PISA scores across pupils (Sutherland et al., 2007).

8. A few years ago, the World Health Organisation (WHO, 2000) analysed the effectiveness of health care systems recognising the multiplicity of objectives. The attainment of five individual goals was combined into a single composite indicator that was used as the outcome in the analysis of the overall effectiveness of the health care system (Annex 1). Reliance on composite indicators of health care system outcomes has been criticised on several grounds (Smith, 2002). In particular, the weighting scheme for objectives has been a contentious issue. 
Panel A. No trade-off between the average health status and its dispersion among individuals

Life expectancy (years), 2007

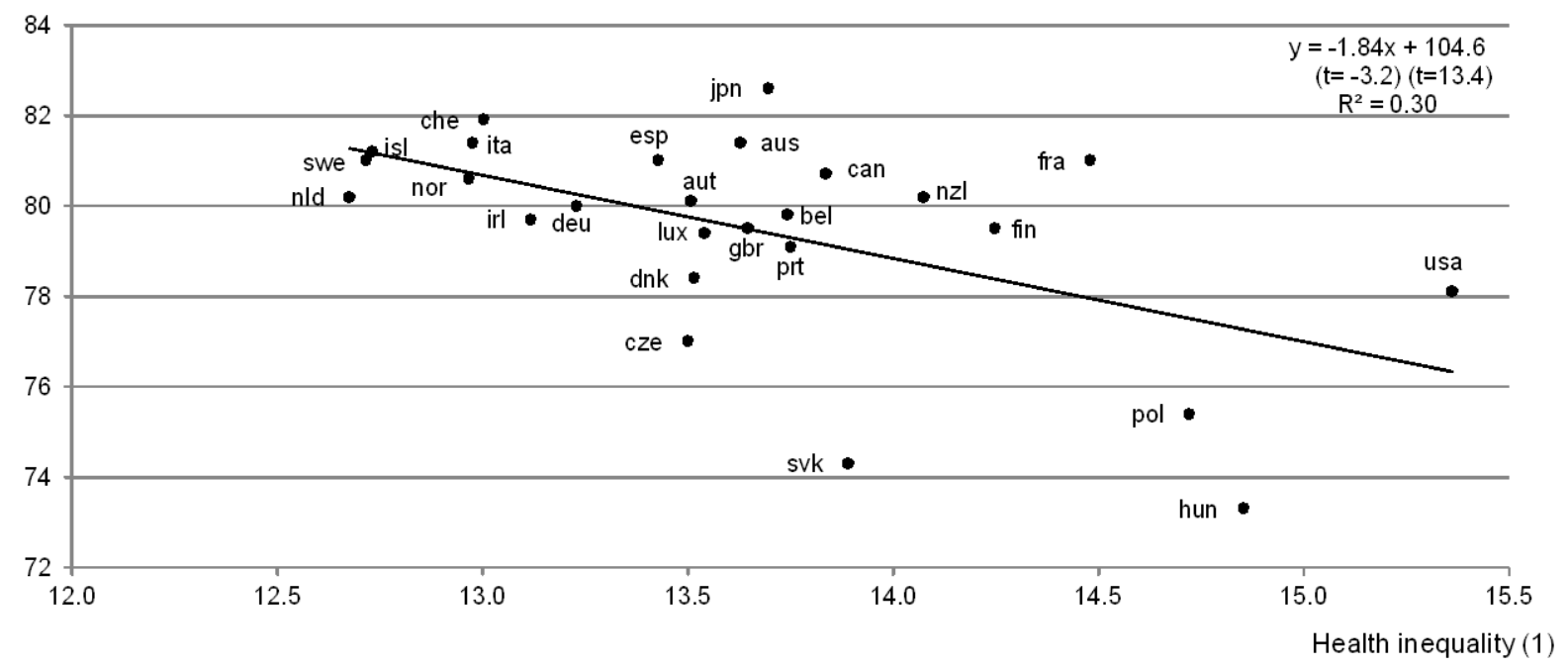

Panel B. Weak correlation with the regional dispersion of physicians

Dispersion in age-adjusted mortality rates across regions $(2)$

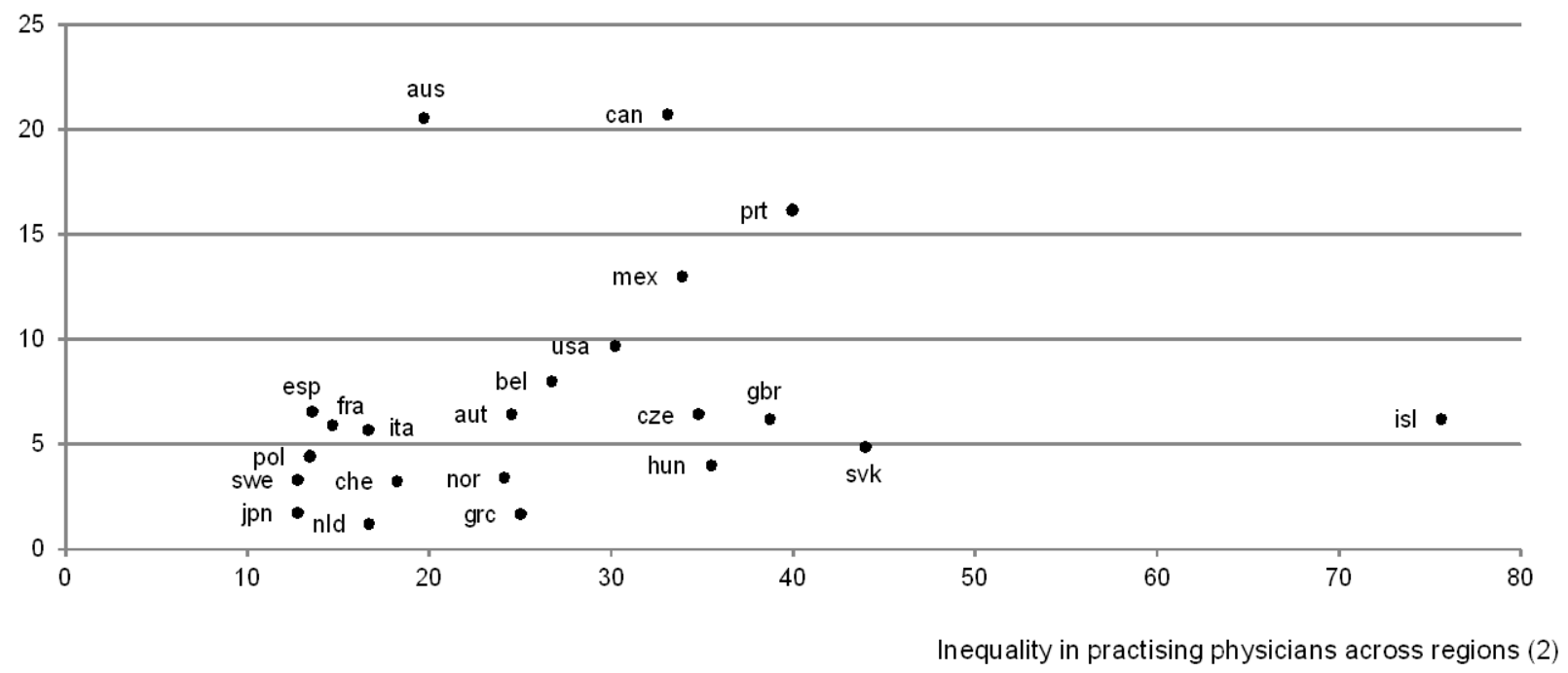

1. Measured by the standard deviation in mortality ages for population older than 10. Calculations are based on 2007 data or latest data available.

2. Inequality across regions is proxied by the dispersion of regional mortality rates expressed as a percentage of national mortality rates. In the same

way inequality in practising physicians across regions is derived from the number of physicians per capita in each region expressed as a

percentage of the number of physicians per capita at the national level. Data concen the year 2004.

Source: Human Mortality Database (HMD); OECD Health Data 2009; OECD Regions at a Glance, 2007.

\section{Adopting an outcome and system-level approach to measure performance}

13. The efficiency measure used in this paper focuses on health care outcomes rather than on outputs. Over the past years, several statistical offices and the OECD undertook work to develop output-based measures for health services in the national accounts so as to better measure productivity growth in the health care sector (Schreyer et al., 2010). ${ }^{9}$ In this context, health care outputs are mainly measured by the

9. In the National Accounts, health and education services have traditionally been measured by inputs (i.e. basically costs) - a major obstacle to the proper measurement of productivity growth. 
number of medical treatments and activities (e.g. surgical procedures and doctor consultations), adjusted when possible for their quality. This paper does not adopt this approach for two main reasons. First, this approach is not yet fully and consistently implemented across OECD countries. Second, and conceptually more importantly, individual medical outputs may be produced efficiently, but still have only a very limited impact on the health status of the population if they are not allocated adequately. This paper thus focuses on health care outcomes, defined as those gains in the population's health status which can be attributed to health care spending. This approach is challenging because it requires disentangling the impact of health care from other factors (e.g. socio-economic environment and lifestyle) on the health status (Figure 3). In addition, gains in health status due to health care consist not only in increased longevity (for which data are readily available) but also in a better quality of life (e.g. less morbidity and associated disabilities). ${ }^{10}$

Figure 3. From health care inputs to outputs and outcomes

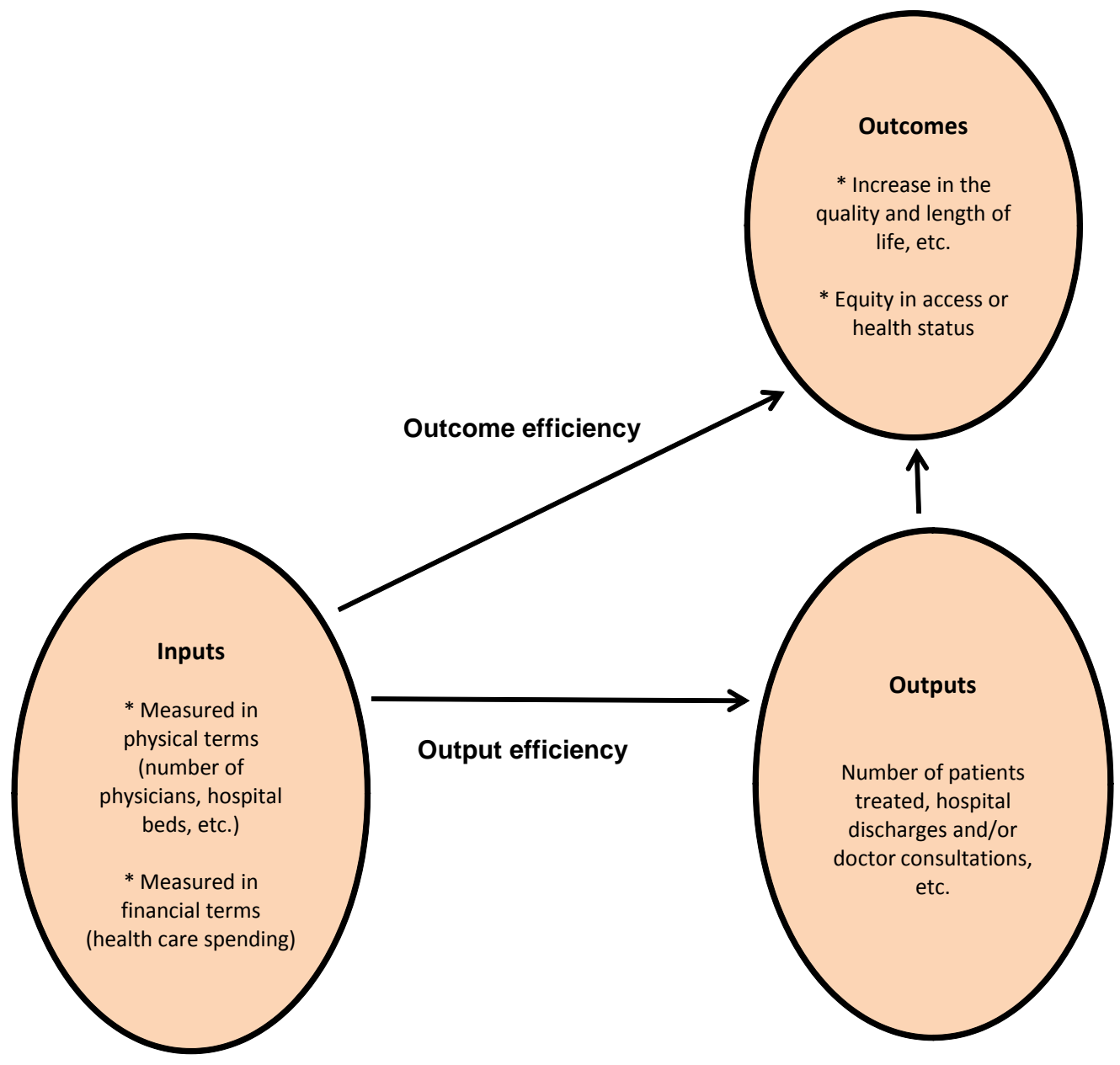

10. Although longevity indicators adjusted for morbidity or disability are better health status indicators, timeseries are often lacking. The available data however suggest that the cross-country correlation between life expectancy and Health Adjusted Life Expectancy (HALE) - the number of years expected to be lived in what might be termed the equivalent of "full health" - is both very high and significant (see Annex 2, Table A2.2) 
14. Three main options exist to draw cross-country comparisons of efficiency: a sub-sector approach, a disease-based approach and a system-level approach (Häkkinen and Joumard, 2007). Each has pros and cons.

15. The sub-sector approach (in-patient care, out-patient care, pharmaceuticals, long-term care) has the advantage of focusing on more homogeneous activities and lends itself to drawing sector-specific policy recommendations. Patient mobility and the increasing use of activity-based payment systems for hospitals has created a new impetus for cross-country comparisons, at least for in-patient care (Busse et al., 2008; Erlandsen, 2007; Hollingsworth, 2007). In approaches focusing on sub-sectors, performance is most often measured on the basis of outputs (e.g. number of consultations and surgical procedures). Treatment may, however, be provided by different sub-sectors and this could lead to biased cross-country comparisons. ${ }^{11}$ Moreover, outcome measures at the sub-sector level are seldom available because health gains are often the result of a mix of out-patient care, in-patient care and pharmaceuticals, whose respective impact is impossible to disentangle. A sub-sector approach would also not take into account the co-ordination of care within the health system (e.g. between long-term and in-patient care) which has been identified as a key element affecting effectiveness (Hofmarcher et al., 2007). In addition, data on subsector inputs are sparse. Assessing health care spending efficiency with a sub-sector approach is thus difficult.

16. A disease-based approach is conceptually attractive because it focuses on health gains due to specific treatments (e.g. in terms of survival rates after a medical treatment or additional quality-adjusted life years, QALYs). International comparisons may help identifying country-specific weaknesses and thus areas where policy reforms may be most rewarding. As an example, breaking down data on amenable mortality - those deaths that should not occur in the presence of timely and effective health care - by disease group shows that Japan performs very well in international comparison in most domains with the main exception of respiratory diseases (Annex 3, country profile for Japan, Panel B). Similarly, Korea, Mexico, Portugal and the United States underperform in the treatment of infectious diseases. In practice, however, except for the preliminary data on amenable mortality recently developed at the OECD, comparable cross-country data on outcomes by disease are seldom available. ${ }^{12}$ Measuring inputs and costs per disease also faces obstacles (Heijink and Renaud, 2009) as the lack of information on ambulatory care practices and pharmaceutical consumption makes it difficult to fully document a care episode. Deriving cross-country efficiency estimates at the disease level, except for a few specific illnesses, is thus currently not possible.

17. A system-level approach takes into account the interactions between different parts of the health care system and resource allocation across them. One key concern with the sub-sector and disease-based approaches is that individual activities and/or treatments can be very efficient but if the allocation of resources across them is inappropriate, the overall system may still be inefficient. This calls for carrying out the analysis of health care efficiency at the system-level while recognising that performance information at the sub-sector and disease levels could be useful complements. A wide range of input data

11. Efficiency gains have partly been achieved by relying more on out-patient care as technological progress shortened the length and invasiveness of some surgical interventions. Cataract surgery is a case in point. The most efficient countries are likely to be those relying more on (less costly) out-patient care. Drawing cross-country comparisons for these interventions at the hospital level will thus likely lead to biased conclusions since, in the most efficient countries, only the more difficult cases are treated in hospitals and may thus be, legitimately, more costly.

12. Disease-based approaches have been adopted at the OECD. The OECD Ageing-Related Diseases study carried out in the late 1990s aimed at assessing how institutional structures influence variations in diagnoses, treatment, costs and health outcomes, focusing on ischaemic heart disease, breast cancer and stroke (Jacobzone et al., 2002). 
at the system level is available for cross-country comparisons (most notably from the OECD Health Database). Outcome measures - consisting mainly of mortality and longevity indicators - are widely available, although they remain imperfect measures of the health status of the population. In particular, they fail to reflect the full incidence of morbidity, notably in terms of quality of life. In addition, they are influenced by factors outside the health care system that affect the health status of the population. Recent work has aimed to control for such factors (Joumard et al., 2008), allowing the identification of the contribution of health care spending to health outcomes and the degree of efficiency in using available resources. This work also shows that the relative position of countries does not change much when using raw longevity, mortality data adjusted for external causes (e.g. suicides, assaults and transport accidents) as well as health-adjusted life expectancy data - all these health status measures are highly correlated (Annex 2, Tables A2.1 and A2.2). Better data on health care outcomes at the system level are being developed by the OECD, in particular on amenable mortality and health care quality (Box 2). Because their coverage is still limited, these data cannot replace health status indicators when assessing health care efficiency, but they can complement them.

\section{Deriving outcome efficiency measures for health care systems}

\section{Identifying the health gains associated with health care spending}

18. Two methods have been used to derive estimates of countries' relative efficiency in transforming health care resources into longevity. First, panel data regressions have been run to shed light on the contribution of health care and other determinants to the health status of the population (Joumard et al., 2008). This empirical work suggested that changes in health care spending, lifestyle factors (smoking and alcohol consumption as well as diet), education, pollution and income have been important factors behind improvements in health status. In particular, a gain in life expectancy at birth of slightly more than one year for both females and males over the period 1991-2003 could be attributed to the increase in health care spending per capita which amounted to more than 50\% in real terms over the same period (Table 2). It also suggested that health care spending is the single most important factor explaining differences in health status across countries, though other factors also play important roles (Table 3). Panel data regressions can also shed light on performance in transforming health care resources into health status across countries if it is assumed that unexplained differences in health status indicators across countries reflect efficiency differences in the use of inputs. ${ }^{13}$

13. This approach is similar to the one frequently used in growth accounting, where the total factor productivity is derived as the residual of an aggregate production function. The implicit assumption is that all the unexplained country-specific effects and residuals reflect inefficiency, and not measurement errors, omitted variables and other factors. Supporting this assumption are the very low correlations, if any, between the unexplained differences in health status indicators and recent values of key variables which could not be included in panel regressions because cross-country comparable time series were not available - in particular income dispersion (as measured by Gini coefficient), obesity and population density. 


\section{Box 2 . Health care outcome data: amenable mortality and health care quality}

\section{Amenable mortality}

Amenable mortality is defined as those deaths that are potentially preventable by timely and effective medical care. It is measured by age-specific mortality rates for selected causes of death (e.g. asthma below age 45). There is no universal definition, however, as the selection of death causes and age-limits often vary from one study to another. Nolte and McKee (2008) as well as Tobias and Yeh (2009) have proposed different lists of death causes and agelimits. "The OECD has compiled data for these two lists for as many countries as possible, with the results being broadly similar (Figure 4).

\section{Figure 4. Amenable mortality: international comparison using two different lists} All causes, 2006 or latest year available

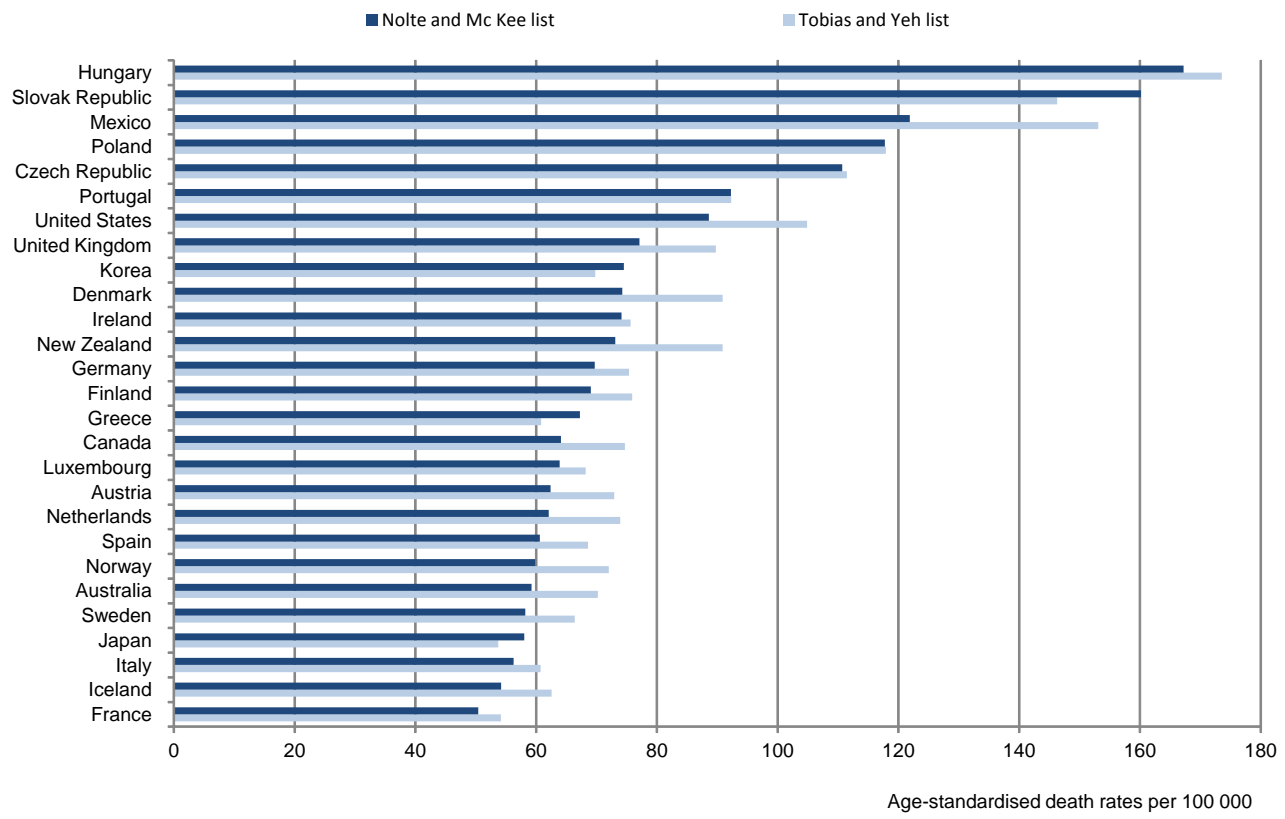

\footnotetext{
1. Amenable mortality lists specify both causes of death and age-specific limits for each cause. Various lists exist, of which those developed by Nolte and Mc Kee (2008) and by Tobias and Yeh (2009).

Source: Preliminary $O E C D$ work.
}

In this paper, the data on amenable mortality, based on the list developed by Nolte and McKee (2008), have been used as an alternative to the crude mortality/longevity data when deriving efficiency estimates (see below). Still, relying on these data raises a number of issues. First, data are not available for Switzerland and Turkey, as well as for Belgium after 1999. Second, the definition of the causes of death that can be considered amenable to health care and associated age limits not only vary across studies, it may also vary over time. Third, the measure is sensitive to differences in diagnostic patterns, death certification and coding of causes of death. This may weaken cross-country comparability. Fourth, amenable mortality, like longevity indicators, does not account for health care interventions aimed at improving the quality of life without prolonging it (e.g. pain relief therapies and mental care).

\section{Health care quality indicators}

Many OECD countries report quality indicators but the availability of internationally comparable data remains limited. To reduce this data gap, the OECD's Health Care Quality Indicators (HCQI) project, that started in 2001, is developing a set of indicators (Garcia Armesto et al., 2007; Kelley et al., 2007; Mattke et al., 2006). The 2009 edition of Health at a Glance presents a selection of $23 \mathrm{HCQIs}$, including screening, survival and mortality rates for selected cancers, vaccination rates and avoidable in-patient admission rates for several chronic conditions. However, differences in definitions, sources and methods could blur international comparisons. In addition, data for many of these indicators are still lacking for a third or more OECD countries. As an illustration, data on survival rates for selected cancers are available for the same year for, at best, 11 countries. As cancer survival rates have increased rapidly over the last decade, drawing cross-country comparisons with such data may introduce significant biases.

* According to the study by Nolte and McKee (2008), which covers 19 OECD countries, amenable mortality constitutes an important proportion of total mortality under age 75 : it ranged from $15 \%$ for French males up to $36 \%$ for Greek and Portuguese females. 
ECO/WKP(2010)25

Table 2. Contributions of main explanatory variables to changes in health status

1991-2003

\begin{tabular}{|c|c|c|c|c|c|c|}
\hline & \multicolumn{4}{|c|}{ Gains in life expectancy } & \multirow{3}{*}{$\begin{array}{l}\text { Decline in infant } \\
\text { mortality rate }\end{array}$} & \multirow{3}{*}{$\begin{array}{l}\text { Memorandum item: } \\
\text { 1991-2003 changes }\end{array}$} \\
\hline & \multicolumn{2}{|c|}{ At birth } & \multicolumn{2}{|c|}{ At 65} & & \\
\hline & Female & Male & Female & Male & & \\
\hline Explained by ${ }^{1}$ : & \multicolumn{4}{|c|}{ Years } & Deaths/1000 live births & Per cent \\
\hline Health care spending & 1.14 & 1.34 & 0.38 & 0.37 & -2.53 & 51.7 \\
\hline Smoking & 0.00 & 0.12 & 0.09 & 0.21 & - 0.21 & -22.6 \\
\hline Alcohol & 0.06 & 0.07 & 0.02 & 0.00 & -0.24 & -6.7 \\
\hline Diet & 0.02 & 0.02 & 0.02 & 0.03 & 0.03 & 7.4 \\
\hline Pollution & 0.15 & 0.29 & 0.15 & 0.22 & -0.75 & - 19.7 \\
\hline Education & 0.50 & 0.49 & 0.26 & 0.14 & - 0.89 & 24.8 \\
\hline GDP & 0.11 & 0.63 & 0.20 & 0.39 & -1.01 & 28.5 \\
\hline \multicolumn{7}{|l|}{ Memorandum item: } \\
\hline Observed changes & 2.49 & 3.45 & 1.40 & 1.63 & -4.67 & \\
\hline
\end{tabular}

1. Contributions of health status determinants are calculated using coefficients estimated by the model (panel data regressions on a sample of countries for which data were available). Observed changes in health status are calculated for the OECD area. The sum of identified contributions may thus differ from the actual change in health status measures.

Source: OECD calculations.

Table 3. Contributions of main explanatory variables to cross-country differences in life expectancy at birth Differences between countries and the OECD average for each variable expressed in years, 2003

\begin{tabular}{|c|c|c|c|c|c|c|c|c|c|}
\hline & \multirow{2}{*}{$\begin{array}{c}\text { Life } \\
\text { expectancy at } \\
\text { birth }\end{array}$} & \multicolumn{8}{|c|}{ Determinants } \\
\hline & & Spending & Education & Tobacco & Alcohol & Diet & Pollution & GDP & $\begin{array}{c}\text { Country- } \\
\text { specific } \\
\text { effect }^{1}\end{array}$ \\
\hline Australia & 2.2 & 0.7 & -0.3 & 0.1 & -0.1 & 0.0 & -0.9 & 0.2 & 2.5 \\
\hline Austria & 0.8 & 1.0 & 0.2 & 0.0 & -0.2 & 0.0 & 0.1 & 0.3 & -0.7 \\
\hline Belgium & 0.8 & 0.8 & -0.3 & 0.0 & -0.2 & 0.0 & 0.1 & 0.2 & 0.2 \\
\hline Canada & 1.8 & 0.9 & 0.4 & 0.1 & 0.1 & 0.0 & -0.8 & 0.3 & 0.9 \\
\hline Czech Republic & -2.7 & -1.8 & 0.5 & -0.1 & -0.3 & -0.1 & 0.0 & -0.6 & -0.3 \\
\hline Denmark & -0.5 & 0.7 & 0.3 & 0.0 & -0.2 & 0.0 & -0.2 & 0.3 & -1.5 \\
\hline Finland & 0.5 & -0.2 & 0.1 & 0.2 & 0.0 & -0.1 & -0.3 & 0.2 & 0.5 \\
\hline France & 1.3 & 0.9 & -0.2 & 0.0 & -0.3 & 0.0 & 0.4 & 0.2 & 0.4 \\
\hline Germany & 0.6 & 0.8 & 0.4 & -0.1 & -0.1 & 0.0 & 0.5 & 0.1 & -1.0 \\
\hline Greece & 0.9 & 0.3 & -0.7 & -0.2 & 0.0 & 0.2 & 0.0 & 0.0 & 1.3 \\
\hline Hungary & -5.6 & -2.0 & 0.1 & 0.0 & -0.3 & 0.0 & 0.5 & -0.8 & -3.1 \\
\hline Iceland & 3.1 & 1.1 & -0.2 & 0.0 & 0.3 & -0.1 & -1.0 & 0.3 & 2.6 \\
\hline Ireland & 0.3 & 0.3 & -0.3 & 0.0 & -0.4 & 0.0 & 0.1 & 0.4 & 0.2 \\
\hline Korea & -0.6 & -2.4 & 0.1 & 0.0 & 0.0 & 0.1 & 0.3 & -0.4 & 1.7 \\
\hline Netherlands & 0.6 & 0.6 & -0.2 & -0.1 & -0.1 & 0.0 & 0.3 & 0.3 & -0.3 \\
\hline New Zealand & 1.5 & -0.6 & 0.2 & 0.1 & 0.0 & 0.0 & -0.5 & -0.1 & 2.3 \\
\hline Norway & 1.5 & 1.8 & 0.5 & 0.1 & 0.3 & 0.0 & -0.3 & 0.7 & -1.5 \\
\hline Poland & -3.4 & -3.5 & 0.3 & 0.0 & 0.1 & -0.1 & 0.4 & -1.1 & 0.5 \\
\hline Sweden & 2.1 & 0.6 & 0.3 & 0.0 & 0.2 & 0.0 & 0.3 & 0.2 & 0.5 \\
\hline Switzerland & 2.5 & 1.5 & 0.4 & -0.1 & -0.2 & 0.0 & 0.9 & 0.3 & -0.4 \\
\hline Turkey & -7.4 & -4.5 & -2.3 & -0.1 & 1.5 & 0.1 & 0.7 & -1.9 & -1.0 \\
\hline $\begin{array}{l}\text { United Kingdom } \\
\text { United States }\end{array}$ & $\begin{array}{r}0.5 \\
-0.5\end{array}$ & $\begin{array}{r}-0.1 \\
2.9\end{array}$ & $\begin{array}{l}0.4 \\
0.5\end{array}$ & $\begin{array}{l}0.1 \\
0.0\end{array}$ & $\begin{array}{r}-0.2 \\
0.0\end{array}$ & $\begin{array}{l}0.0 \\
0.0\end{array}$ & $\begin{array}{r}0.1 \\
-0.6\end{array}$ & $\begin{array}{l}0.2 \\
0.6\end{array}$ & $\begin{array}{r}0.0 \\
-4.0\end{array}$ \\
\hline \multicolumn{10}{|c|}{ Memorandum items: } \\
\hline Maximum range & 10.5 & 7.4 & 2.8 & 0.4 & 1.8 & 0.3 & 1.8 & 2.5 & 6.6 \\
\hline Estimated coeffici & & 0.041 & 0.030 & -0.004 & -0.011 & 0.004 & -0.012 & 0.019 & \\
\hline
\end{tabular}

1. The country-specific effect is calculated as the sum of the country fixed-effect plus the residual of the equation.

Source: OECD calculations. 
19. Second, a Data Envelopment Analysis (DEA) was carried out for the year 2003, with a more limited data set than the panel regressions and thus less explanatory variables. ${ }^{14}$ Three variables were taken into account as inputs in explaining cross-country differences in health status: health care spending per capita, a proxy for the economic, social and cultural status derived from the OECD PISA Survey and a lifestyle variable (diet). The DEA and panel regression results are remarkably consistent in suggesting that population health status could be improved significantly, while keeping inputs constant, in most OECD countries (Figure 5). Potential efficiency gains in the health care sector might be large enough to raise life expectancy at birth by more than two years on average across the OECD (holding all inputs constant) while a $10 \%$ increase in health care spending per capita would increase life expectancy by only three to four months. ${ }^{15}$

\section{Figure 5. Comparing DEA and panel data regression results} Potential gains in life expectancy at birth ${ }^{1}$

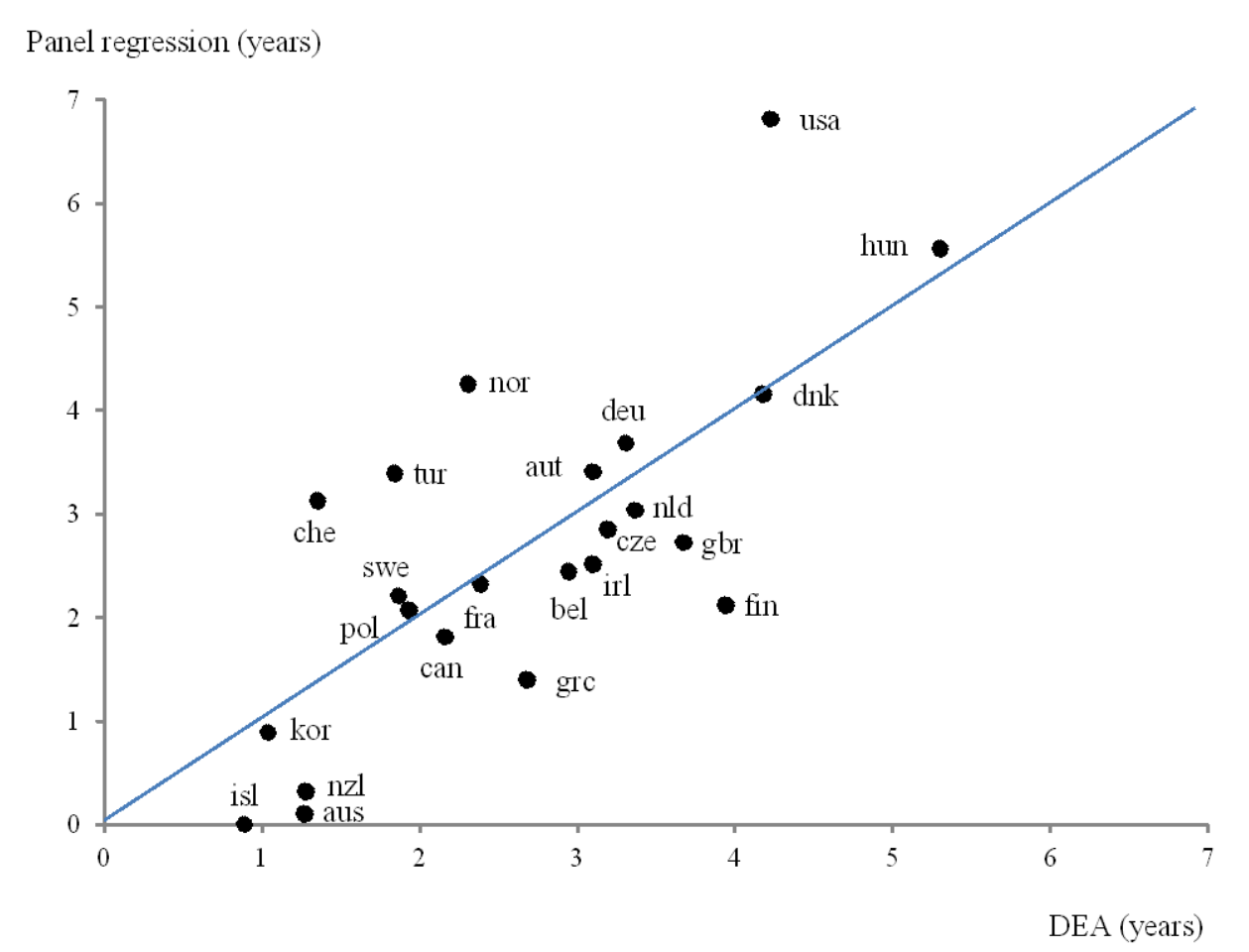

1. Potential gains are measured as the number of years of life that could be saved if efficiency in country $i$ were to be raised to the level implied by the estimated efficiency frontier (DEA) or were equal to the level calculated for the best performing country (panel regressions).

Source: OECD calculations.

14. The small size of the sample restricts the number of inputs which can be included in the DEA Methodological issues raised by implementation of the DEA for health care are presented in Hollingsworth (2007), Jacobs et al. (2006), Box 4 in Joumard et al. (2008) and Spinks and Hollingsworth (2009).

15. It should be further recognised that potential efficiency gains may be vastly underestimated. A similar approach for the primary and education sector carried out at both the national and school levels (Sutherland et al., 2006) showed that potential efficiency gains are much larger when the unit of analysis is the school level. Performance analyses carried out at the hospital level also reveal significant variations in costs within individual countries for the same procedure. In a study on hip replacement costs in nine European countries, Stargardt (2008) noted that "for most countries, within-country cost variations seemed to be greater than between-country cost variations". 


\section{Testing the robustness of the efficiency measures}

20. The efficiency estimates have been updated and upgraded. Updating panel regression results would produce estimates for the period average, as opposed to the end of the time period, which is of interest here. Preference was thus given to the DEA approach, using data for 2007 (i.e. the latest year for which data are available). ${ }^{16}$ The specification of the DEA has been further improved by taking into account a broader range of socio-economic and lifestyle factors and alternative specifications have been tested to assess the robustness of the DEA results. In particular, three alternative outcome measures have been used: life expectancy at birth and at 65 as well as amenable mortality - amenable mortality more closely reflects the performance of the health care sector but data are lacking for three countries and end in 2003 for several others. The DEA has also been upgraded on the input side. First, a 17-year lag was introduced for alcohol and tobacco consumption. Second, the DEA has been performed with different input combinations: health care resources measured either by the level of spending per capita or by the number of health care professionals, and the socio-economic environment and lifestyle factors measured either by a composite indicator or through various combinations of two variables (air pollution, alcohol consumption, tobacco consumption and an index of economic, social and cultural status).

21. Overall, the DEA results appear to be quite robust to changes in specification. ${ }^{17}$ Using a better measure of health care system performance (amenable mortality, instead of life expectancy) would improve the relative position of some countries, most notably France, Greece and Italy (Figure 6, Panel A). It also suggests a less favourable position for some others (in particular the Czech Republic, Hungary and Portugal). Measuring health care resources in volume terms (number of health professionals) also makes some difference (Figure 6, Panel B), in particular for those countries where compensation is rather low by OECD standards (e.g. the Czech Republic, Hungary and the Slovak Republic). However, the overall picture does not change much. DEA results are also rather close to those obtained for 2003, with the main changes reflecting revisions to the data on life expectancy (notably for Italy, Luxembourg and Turkey).

22. While efficiency estimates derived from both panel regressions and the DEA provide a useful indication on potential efficiency gains, they should not be taken at face value for a variety of reasons. Given the lack of consistent data accounting for morbidity and disability, efficiency assessment can fail to account for cross-country differences in the contribution of health care to relieve symptoms and improve quality of life. On the input side, although the approach is common and has been designed to include as many of the factors influencing the health status as possible, some determinants may be missing, such as those related to physical exercise, health and safety regulations, income dispersion and housing conditions. Still, the correlation between efficiency estimates and data (in most cases very fragmented) for some of these dimensions - e.g. Gini coefficients, obesity and population density - remain very low, if existent at all.

\section{Complementing aggregate efficiency indicators by "intermediate" performance indicators}

23. Outcome-based efficiency measures at the system level can be complemented by efficiency measures based on outputs, by indicators on the quality of care and by information on the share of resources devoted to administration as opposed to actual care. Each of these "intermediate" performance indicators is partial, and as a result potentially misleading if considered in isolation. Still, they can provide indications of country specificities and point to areas in need of reform.

16. The institutional indicators largely reflect the situation in 2008 , but health institutions tend to change only very slowly over time (Kotzian, 2007).

17. DEA results are sensitive to measurement errors and statistical noise. Confidence intervals, generated by a bootstrapping method, are shown in Annex 2, Figure A2.1. 


\section{Figure 6. DEA efficiency scores are fairly robust to changes in specification}

Panel A. Sensitivity of DEA efficiency scores to the definition of outcomes ${ }^{1}$

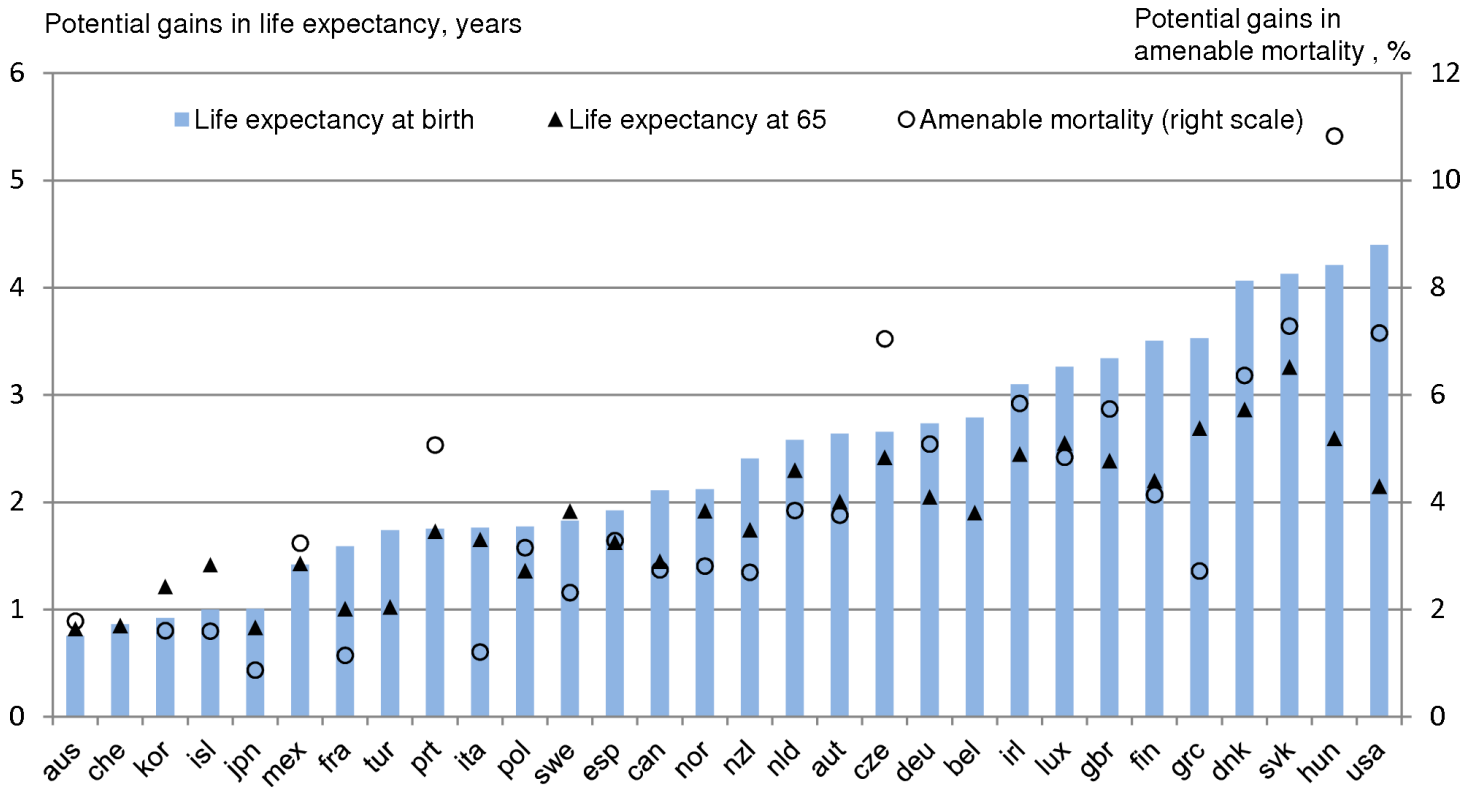

Panel B. Sensitivity of DEA efficiency scores to the inclusion of different inputs ${ }^{2}$

Potential gains in life expectancy, years

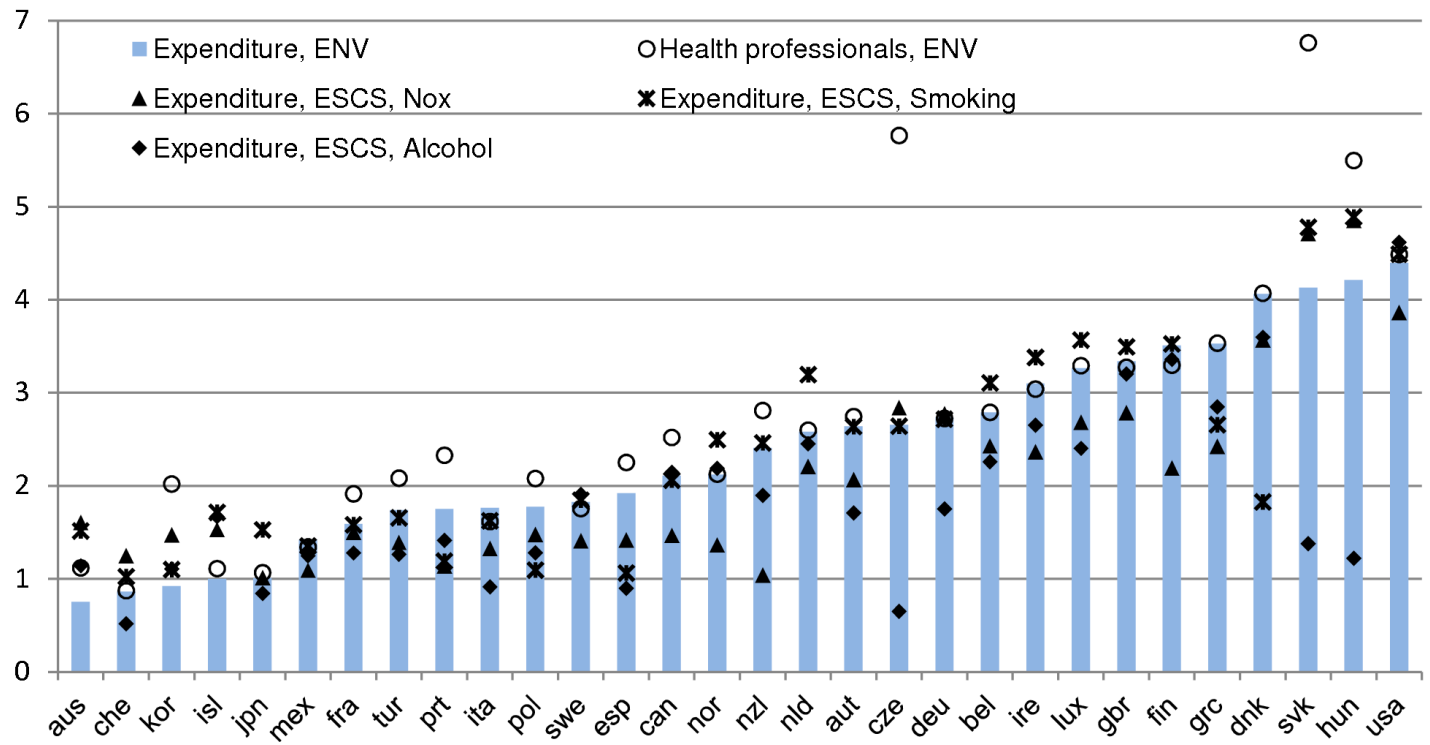

Note: Potential gains are measured either by the number of years of life that could be saved if efficiency in country i were to be raised to the level implied by the estimated efficiency frontier or by the proportion by which amenable mortality could be reduced while holding inputs constant and under the assumption of non-increasing returns to scale.

1. In this panel, all DEAs were performed with 2 inputs: health care spending per capita and a variable referred in Panel B as ENV. ENV is a composite indicator of the socio-economic environment (GDP per capita, educational attainment) and lifestyle factors (nitrogen oxide emissions, consumption of fruits and vegetables, lagged consumption of alcohol and tobacco - 1990 data). All DEAs refer to 2007 except in the case where amenable mortality rates were taken as the outcome since these are only available until 2003 and for 27 countries.

2. In this panel, all DEAs were performed with life expectancy at birth as the outcome. ESCS is an index of economic, social and cultural status derived from PISA 2006. Nox represents nitrogen oxide emissions per capita. All data refer to 2007 except in the case of alcohol and smoking, for which 1990 data were used, and for Nox, which is only available until 2005.

Source: OECD calculations; Health Data 2009. 
Efficiency measures based on outputs are poor proxies for aggregate performance but help identifying reform priorities

24. Efficiency measures linking health care outputs - instead of outcomes - and resources are often used and mainly focus on hospital care (Hussey et al., 2009), largely reflecting data availability. The OECD Health Data contain information which can be used to derive proxies for efficiency in resource utilisation in the in-patient care sector. The average length of stay (ALOS) in hospitals is one of them. All other things being equal, a shorter stay will reduce the cost per discharge and shift care from in-patient to less expensive post-acute settings.

25. The ALOS for total in-patient care displays significant cross-country variation (Figure 7), partly reflecting differences in the degree of reliance on in-patient care for the elderly. As an illustration, in Japan, where hospitals play an important role in providing long-term care, the ALOS in in-patient care is about four times the OECD average. ${ }^{18}$ Focusing on disease-specific ALOSs can remove some of the heterogeneity arising from in-patient conditions across countries. ${ }^{19}$ Disease-specific ALOSs thus likely reflect the impact of financial incentives embodied in hospital payment methods as well as other institutional factors better (such as the availability of beds for convalescent patients in rehabilitation centres). In Ireland for instance, where hospitals are partly paid on a per-diem basis, disease-specific ALOSs tend to be above the OECD average. Two other indicators are often considered to be relevant for assessing efficiency in the use of existing medical facilities: the turnover rate - the number of cases per available acute care bed - and the occupancy rate for acute care beds. ${ }^{20}$

18. In Japan, moving away from a per diem payment scheme for hospitals toward a DRG scheme has been considered as a priority to reduce the ALOS for acute care (OECD, 2009b). Data on disease-specific ALOS for Japan are, however, not available in OECD Health Data.

19. Data on ALOS are available in OECD Health Data for about 130 diagnostic categories. To select a reasonable number of categories for in-depth analysis, the following criteria have been used: the diseases are frequent, well-recognised and/or rarely associated with other diagnostic categories (so as to limit the risk of differences in categorisation across countries). The following disease-specific ALOSs have been selected: three categories of cancers (trachea, bronchus and lung; breast; colon, rectum and anus); acute myocardial infarction (AMI); tuberculosis; and femur fractures.

20. The number of exams per high-tech equipment (e.g. MRIs and scanners) could also provide useful information but data are lacking for many countries in OECD Health Data. 


\section{ECO/WKP(2010)25}

Figure 7. International comparisons based on a selection of efficiency measures based on outputs

2007 or latest available year

Average length of stay (ALOS): in-patient care

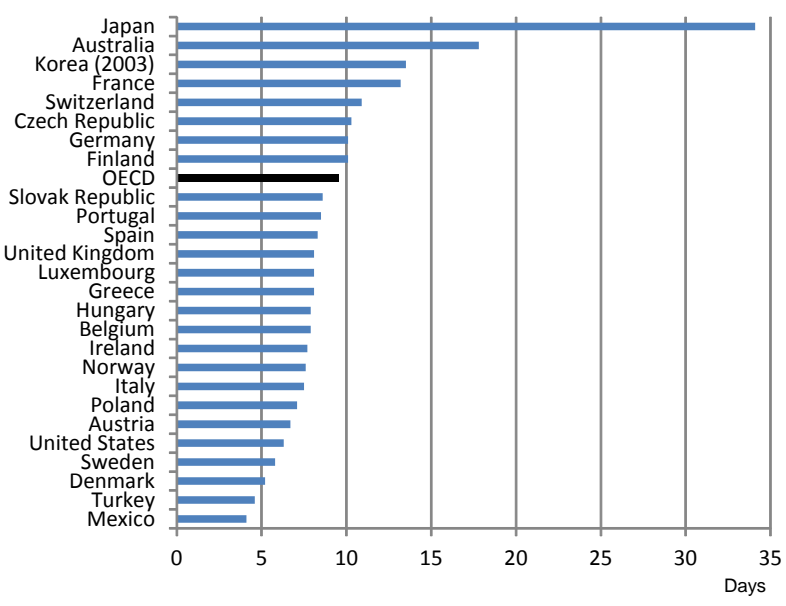

ALOS following lung cancer

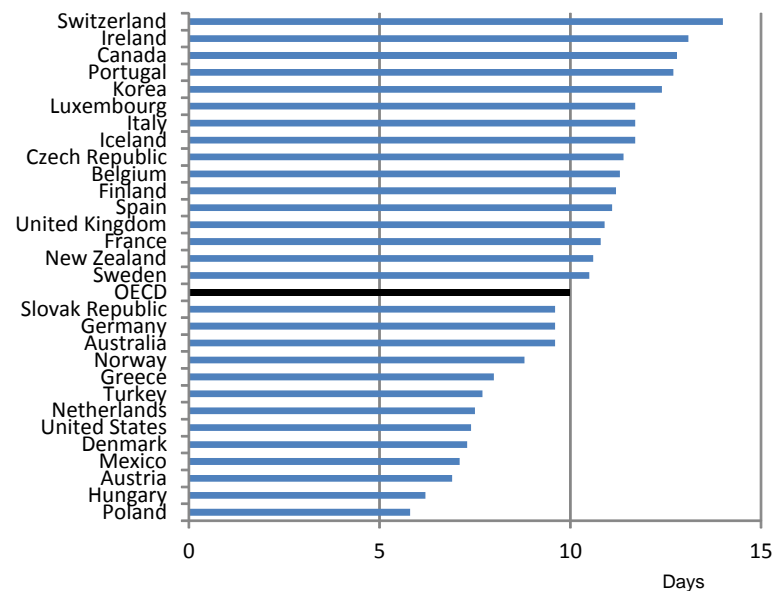

Occupancy rate of acute care beds

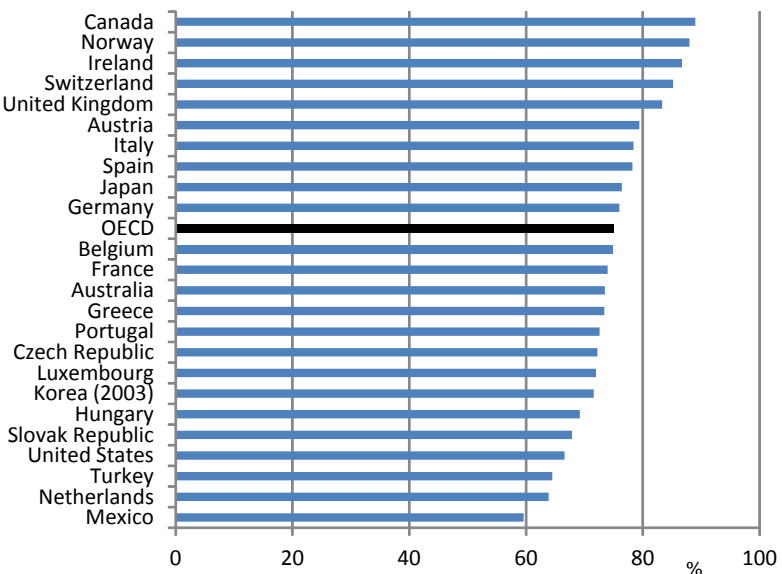

Source: OECD Health Data 2009
ALOS following acute myocardial infarction (AMI)

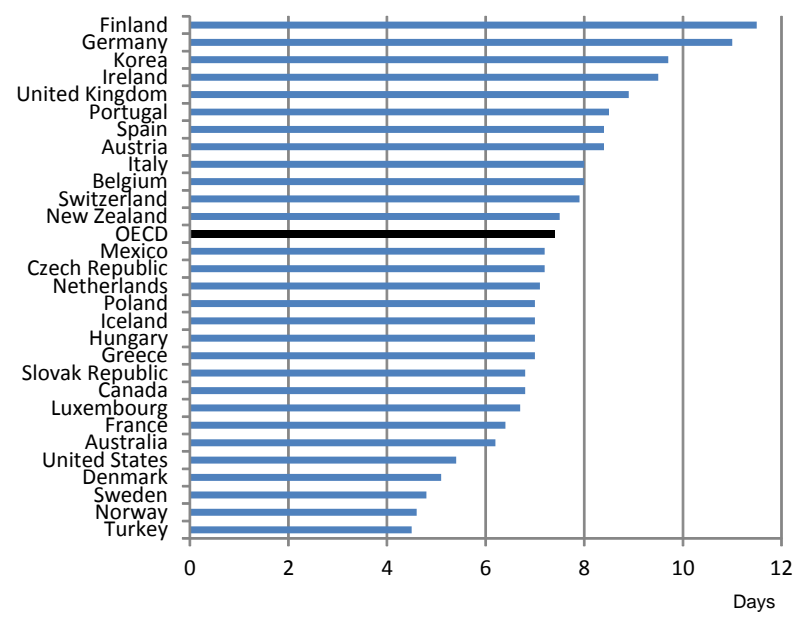

Turnover rate for acute care beds

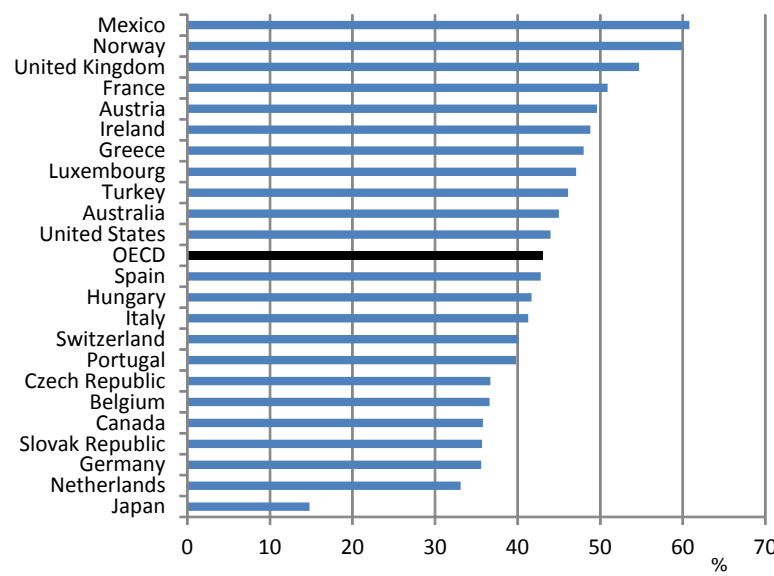

Number of consultations per doctor

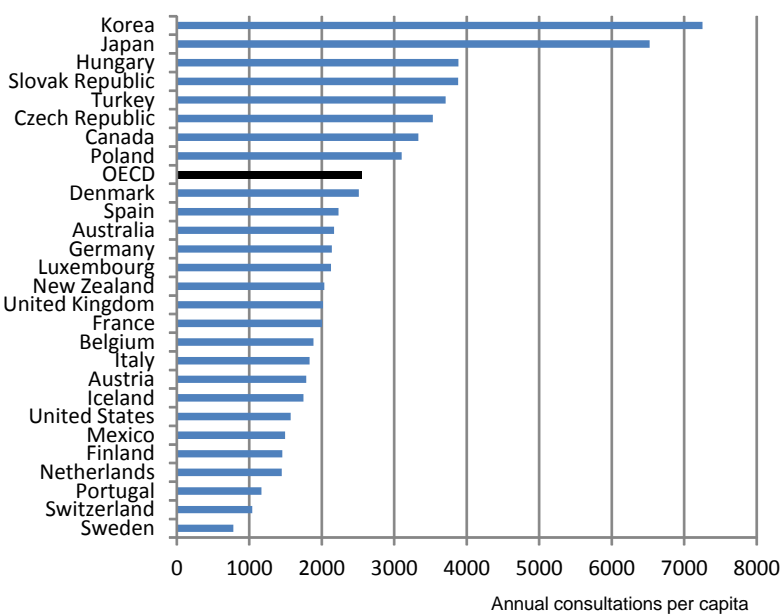


26. Although very close in essence, efficiency indicators for in-patient care are not always highly correlated (Annex 2, Table A2.3). There are some correlations across disease-specific ALOS, but they are far from being systematic - for instance, the ALOS for patients with tuberculosis seems to be largely unrelated to the ALOS for other diseases. This suggests that countries can be efficient in treating some diseases but not others. Furthermore, efficiency indicators for in-patient care should be interpreted with care. A high occupancy rate (usually considered as an efficient use of resources) can either reflect long ALOS (usually considered as an inefficient use of resources) or a high turnover rate. ${ }^{21}$ In addition, crosscountry correlations between these in-patient care efficiency measures and outcome efficiency scores derived from the DEA are either not significant or even wrongly signed. The significant and positive correlations between the DEA efficiency scores and both the aggregate ALOS and the ALOS for two types of cancers are particularly puzzling. This could be explained if too short in-patient stays create a serious risk of medically-induced patient re-admissions or cost-shifting from acute care to other care settings (Kondo et al., 2009). No internationally comparable data on re-admission rates are available to adjust ALOS data. However, various empirical studies on US and German hospitals conclude that the implementation of case management systems and/or payment per case systems for hospitals led to a reduction in the length of stay without affecting treatment quality (e.g. Kainzinger et al., 2009). Shorter ALOSs also reduce the risk of hospital-acquired infection.

27. The number of consultations per doctor is sometimes used as an indicator of efficiency for the out-patient care sector. There is huge cross-country variation in the number of consultations per doctor, ranging from above 6500 in Korea and Japan per year to less than 1500 in Finland, Mexico, the Netherlands, Portugal and Sweden. However, the number of consultations per doctor may not be a good indicator of efficiency for at least two reasons. First, the nature and content of consultations likely vary significantly across countries. In particular, aggregating consultations by general practitioners and specialists may not be warranted and their split is not available. Second, too short consultations may be of poor quality and/or cost inefficient. ${ }^{22}$ Moreover, there is no significant correlation between this indicator and the DEA (outcome) efficiency scores.

28. The level of administrative costs is sometimes seen as a relevant element in assessing health care system efficiency - high administrative costs would represent a diversion of resources away from productive use. In 2007, these costs amounted to less than $2 \%$ of total current expenditure in Denmark, Hungary, Italy, Norway and Portugal but to $7 \%$ or more in Belgium, France, Luxembourg, Mexico, New Zealand and the United States. High administrative costs may, however, not be inefficient if they allow a better use of existing medical resources. Woolhandler et al. (2003) suggest that a system with multiple insurers and market-based competition at the provider level may be intrinsically costlier. In practice, crosscountry correlations between administrative costs and output-based efficiency indicators are either not significant or do not go in the expected direction. There is, in addition, no significant correlation between high administrative costs and outcome-based (DEA) efficiency scores.

29. Overall, output-focused efficiency indicators raise a number of problems if they are used as proxies for overall system efficiency. First, they do not deliver a consistent message. Using them to assess efficiency in the health care sector would require choosing among them or designing a method to aggregate them, both of which suffer from severe drawbacks. Second, indicators based on currently available data focus almost exclusively on the in-patient care sector while some medical interventions and surgical

21. The formula linking the occupancy rate (OR), turnover rate (TR) and ALOS is as follows: $\mathrm{OR}=\mathrm{ALOS} * \mathrm{TR} / 365$. Definitions and methods for collecting data may not be fully consistent and this relationship does not always hold exactly.

22. In Japan, one common complaint is that patients spend three hours waiting for a consultation of only three minutes with the doctor. To mitigate this problem, the government reduced reimbursement of medical consultations of less than five minutes (OECD, 2009b). 
procedures are increasingly performed on a day care basis at a reduced cost. Cataract surgery is an example. Available data reveal that the share of cataract surgeries carried out on a day care basis varies significantly across countries, from above $97 \%$ in Canada, Finland, the Netherlands, and Sweden to below $65 \%$ in the Czech Republic, Hungary, Luxembourg and Poland. Third, measuring efficiency in the outpatient care sector is far from obvious as the heterogeneity of cases is large and largely undocumented. Designing a relevant efficiency indicator for the pharmaceutical sector would be even more difficult. Fourth, differences in the quality of medical output should be accounted for.

30. While efficiency measures focusing on health care outputs cannot be an alternative to efficiency measures focused on outcomes, they can offer a complement and help identifying country specificities and reform priorities. Among the countries with below-average outcome efficiency scores (DEA), many tend to have above-average disease-specific ALOSs, including Belgium, the Czech Republic, Finland, Ireland, Luxembourg and the United Kingdom. Most other countries with below-average outcome efficiency scores are characterised by a low occupancy rate of acute care beds, including Greece, Hungary, the Netherlands, the Slovak Republic and the United States. Scope for improvement can also be identified for countries with relatively high DEA scores. As an illustration, Australia, France, Japan, Korea and Switzerland are all characterised by longer lengths of stay for in-patient care, partly reflecting a heavy reliance on hospitals for long-term care. The share of resources devoted to administration is also high in France, and to a lesser extent in Switzerland.

Quality indicators are useful but need to be developed further

31. In assessing health care system performance, the quality of health care outputs needs to be taken into account. Constrained by data availability, the analysis in this paper was restricted to a small number of Health Care Quality Indicators (HCQIs):

- Three outcome measures on care for chronic conditions - avoidable hospital admission rates for asthma, for chronic obstructive pulmonary diseases (COPD) and for congestive heart failures (CHF) - with the assumption that high admission rates may be an indication of poor quality of care because in most cases these conditions could be prevented and/or handled without hospitalisation;

- Two outcome measures on care for acute exacerbations of chronic conditions - in-hospital case fatality rates within 30 days after admission for acute myocardial infarction (AMI) and for ischemic stroke. Coronary artery disease remains the leading cause of death in most OECD countries but much of the reduction in mortality rates since the 1970s can be attributed to lower mortality from AMI (OECD, 2009a). Given the variety of services and system devices that need to be mobilised to provide care for this illness, the AMI case-fatality rate is regarded as a good outcome measure of acute care quality. Likewise, ischemic stroke is an important cause of death and stroke case-fatality rates have been used for hospital benchmarking within and between countries.

- Three process measures on prevention - rates of (childhood) vaccination for measles and for diphtheria, tetanus and pertussis (DTP) and rate of influenza vaccination for elderly people. While these are more process or output than outcome indicators, they have some advantages. In particular, they are more readily available and can be used to derive policy recommendations. ${ }^{23}$

23. Process measures do not measure outcomes but have some advantages when there is good evidence that links the care process to desirable outcomes. They are often more reliable and can be obtained on a regular basis. They also directly indicate the actions needed to improve care (Crombie and Davies, 1998). Smith (2002) further considers that process measures are often more likely to offer a more satisfactory 
32. These indicators provide very useful information on some of the weaknesses and strengths of each country's health care system. There are wide cross-country variations for each of these indicators but no unique "ranking" - most countries are good in some areas but less so in others (Figure 8). As an example, Italy scores very well on avoidable admissions for both asthma and COPD, but compares less favourably on avoidable admissions for CHF. Likewise, Korea performed best on in-hospital case-fatality rates for AMI, but also the worse for ischemic stroke in 2007. In addition, these indicators are not all significantly correlated with life expectancy at birth and amenable mortality (Annex Table A2.2). Indicators on the quality of care for chronic diseases (i.e. avoidable admission rates) are reasonably well associated with life expectancy, equity in longevity and also efficiency scores derived from the DEA. The relations between vaccination rates and other HCQIs, as well as health outcome measures, are far less clear cut. Overall, a close look at HCQIs helps identifying country specificities and reform priorities, while keeping in mind that these indicators should be treated with care for at least two reasons: data comparability problems are in some cases important and these indicators remain partial. As an example, while Austria scores relatively well on most output-efficiency measures focused on the in-patient care sector, indicators of the quality of care are less favourable (Annex 3). In particular, avoidable in-patient admissions for COPD and CHF seem high and vaccination rates low, possibly signalling weaknesses in preventive care and/or in the out-patient care sector.

\section{Building indicators for health policy and institutions}

33. A key objective of this paper is to assess how the design of institutions can affect the efficiency of health care systems. Data on health policies and institutions had long been missing. A dataset on health institutions and policies has been developed, based on a questionnaire. Responses from 29 countries were received by early April 2010 (the United States did not respond). The wide-ranging dataset (269 mainly qualitative variables) was transformed into 20 indicators on health policies and institutions to take values ranging from 0 to 6 . In most cases, these indicators reflect the existence of regulations and/or incentives (e.g. whether or not a cap on health care spending was imposed via the budget process). Some indicators were, however, built directly from the (quantitative) Health Data, with the implicit assumption that these captured well a policy dimension. ${ }^{24}$

34. This section links the indicators to the health policy objectives. It discusses the potential impact of policies and institutional features and provides a snapshot of OECD countries' scores for each indicator. It also provides a Principal Component Analysis to assess empirically how the various institutional features are combined in practice.

measure of contemporary system performance than contemporary health status measures which reflect years of population exposure to the health care system and external influences (pollution, socioeconomic factors, etc.).

24. As an example, the degree of price signals imposed on users was built from data on out-of-pocket payments as a share of total health care spending. 


\section{$\mathrm{ECO} / \mathrm{WKP}(2010) 25$}

\section{Figure 8. International comparisons based on a selection of health care quality indicators}

2007 or latest available year

Avoidable admissions: chronic obstructive pulmonary diseases

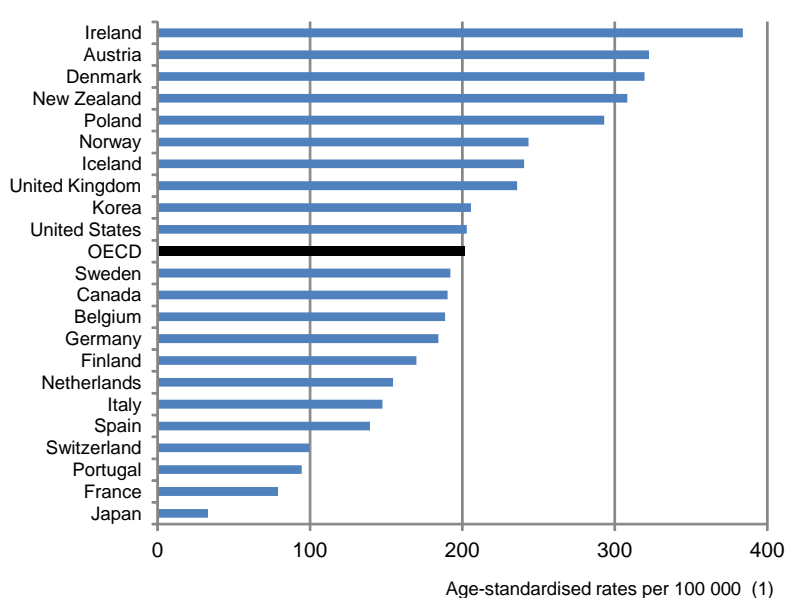

Avoidable admissions: asthma

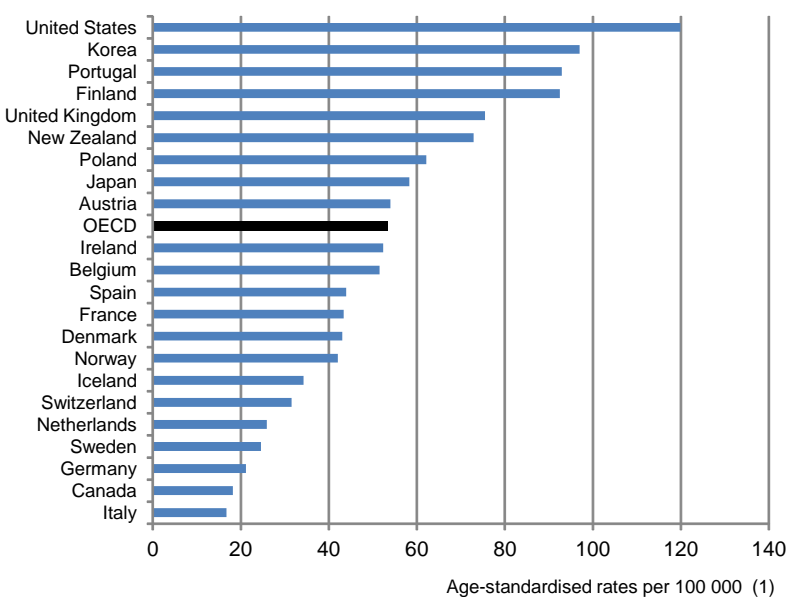

Avoidable admissions: congestive heart failure

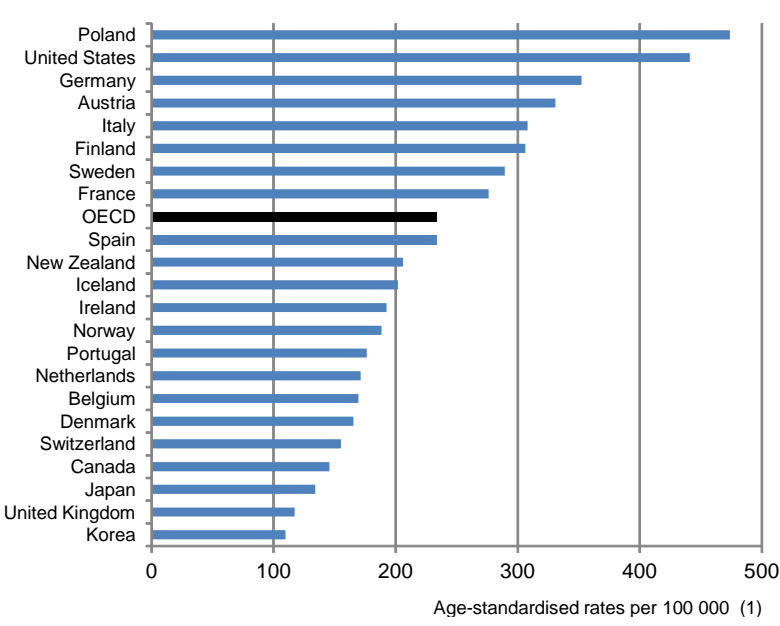

Vaccination rates for diphtheria, tetanus, and pertussis (DTP)

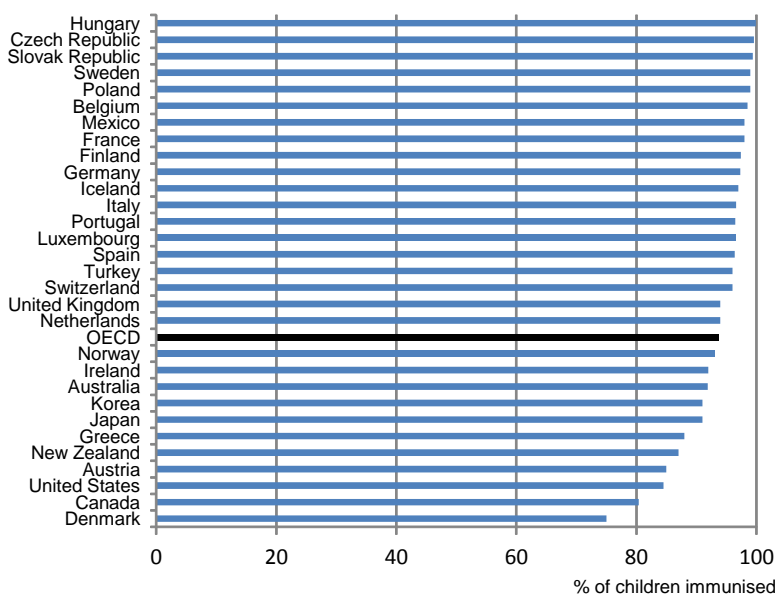

Vaccination rates for measles

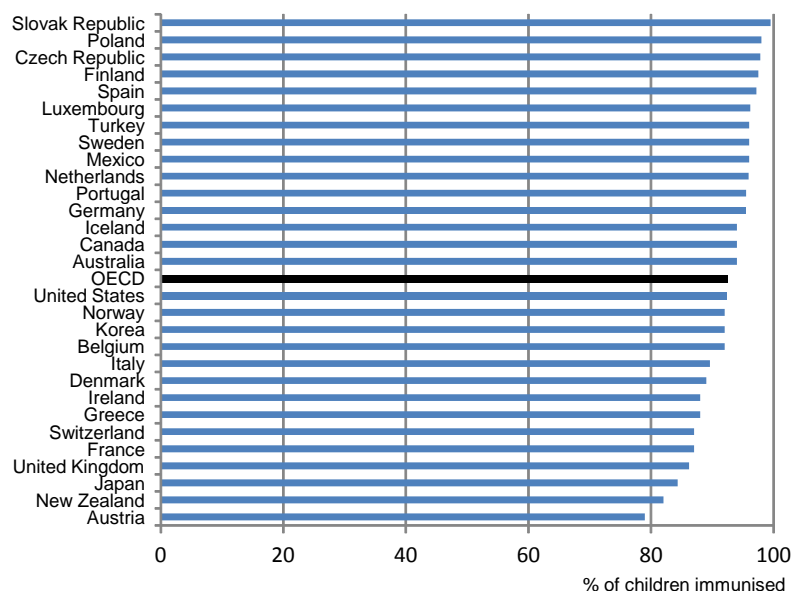

Vaccination rates for influenza

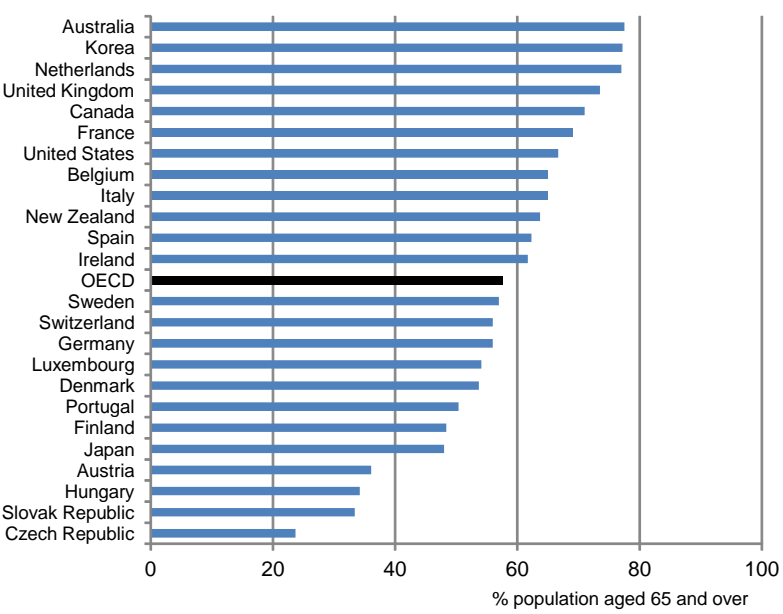

1. Population aged 15 and over Source: OECD Health Data 2009 


\section{Policy settings as seen through the prism of indicators}

35. In pursuing the two core policy objectives under a budget constraint, OECD countries have relied on various instruments (Figure 9 and Table 4). The main considerations which have shaped the tree structure for the indicators are as follows:

- The main policies and institutions affecting the health status of the population are those governing the behaviour of providers, payers and users. Policy approaches differ considerably across countries. Some countries have relied on a command-and-control approach while others have given market signals a more prominent role to steer the demand and supply of health care services. However, given the market failures in the health care sector, market-orientation and regulation are often complementary (Smith, 2008a). In practice, many countries that typically relied mainly on a command-and-control approach have gradually introduced market mechanisms. And the United States, where market mechanisms for health insurance have been prevalent, is now considering tightening regulations. ${ }^{25}$

- The level of basic health insurance coverage is a key determinant in promoting equity in access. While a vast majority of OECD countries have reached almost universal coverage, there are still some differences in the scope of goods and services covered, as well as the level and distribution of out-of-pocket payments.

- In controlling public spending, approaches to set and share the spending envelope and the allocation of responsibilities across levels of government play a key role. Also the regulation of prices paid by third-party payers and of the workforce and equipment is important.

\section{Steering the demand and supply of health care: indicators on market mechanisms and regulations}

36. In regulating the demand for, and supply of, health care services, countries have relied on command-and-control approaches and market mechanisms or a mix of the two. Command-and-control approaches, including public delivery of health care services and controls on health care employment and prices, have contributed to keep public spending under control but have often had adverse side effects, including low productivity, long waiting times and dissatisfaction with health care systems. On the other hand, the pervasiveness of serious market failures (Annex 4) in the health care sector means that markets alone cannot produce efficient outcomes (Arrow, 1963; Docteur and Oxley, 2003; Ennis, 2006; Hsiao and Heller, 2007). As indicated by the Survey on Health System Characteristics, the actual mix between command-and-control approaches and market mechanisms differs significantly across countries. Also, countries relying intensively on market mechanisms tend to implement simultaneously various regulations to steer the demand and supply of health care services.

25. Both of the 2009 Health Reform bills passed by the Senate and House of Representatives included provisions that limit insurance companies' ability to charge premiums based on individuals' characteristics and prohibit them refusing to sell or renew insurance contracts due to an individual's health status. 
Figure 9. The tree structure for the indicators on health policies and institutions

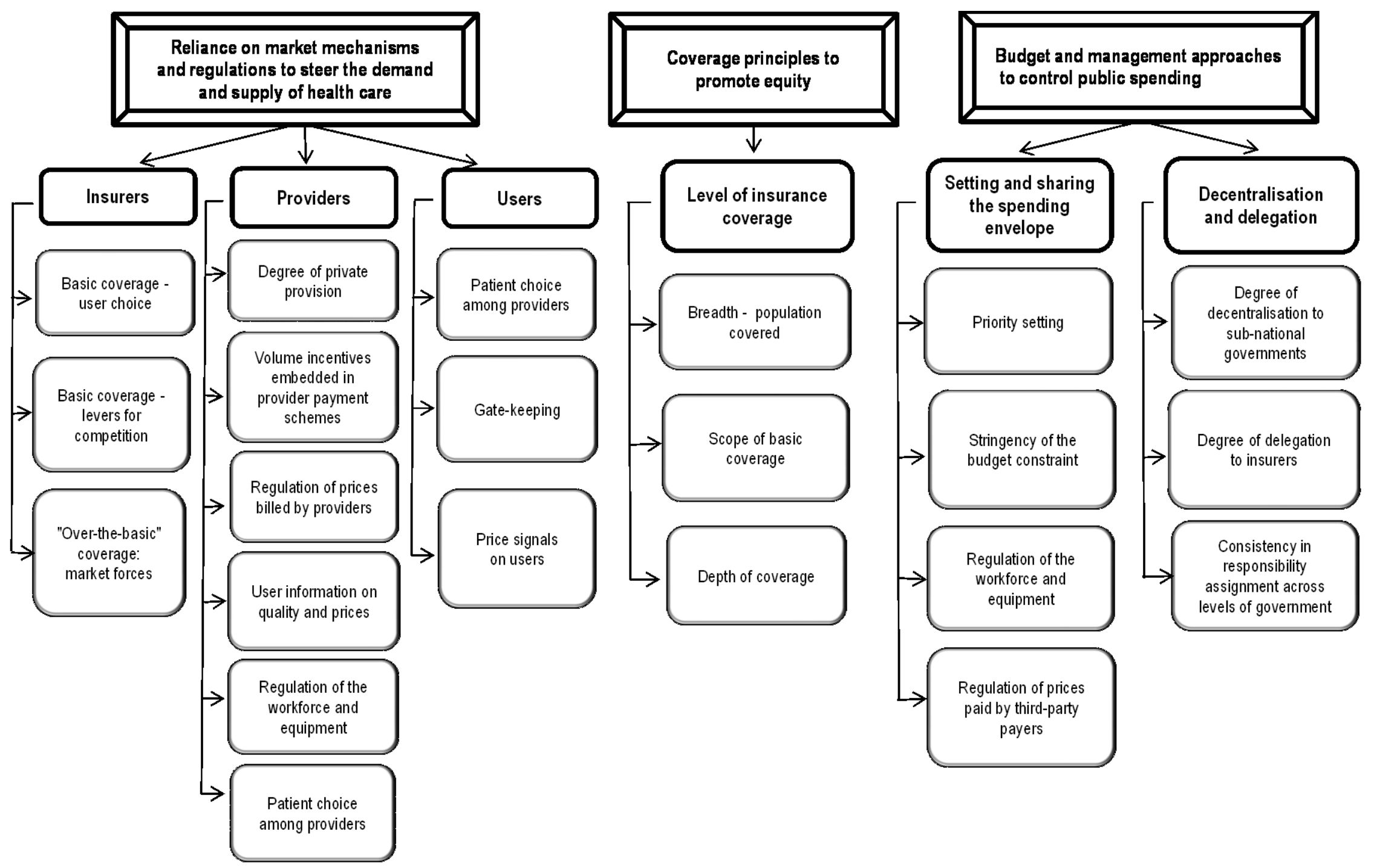


Table 4. Overview of the indicators on health policies and institutions

\begin{tabular}{|c|c|}
\hline $\begin{array}{l}\text { Reliance on market mechanisms and regulations to steer } \\
\text { the demand and supply of health care }\end{array}$ & Main criteria taken into account \\
\hline \multicolumn{2}{|l|}{ 1. Insurers } \\
\hline 1.1 Basic coverage - user choice & $\begin{array}{l}\text { Type of coverage (single national or local schemes, multiple insurers). In case of multiple insurers, number of insurers, market shares and ability of } \\
\text { people to choose their insurer. }\end{array}$ \\
\hline 1.2 Basic coverage - levers for competition & $\begin{array}{l}\text { Insurers' ability to modulate the benefit basket, the level of coverage or premiums and to contract with providers. Existence of a risk-equalisation } \\
\text { scheme. Availability of information for consumers on premiums/coverage and on insurers' performance. }\end{array}$ \\
\hline 1.3 "Over the basic" coverage: market forces & $\begin{array}{l}\text { Share of population covered by non-primary insurance (duplicate, complementary or supplementary private health insurance) - share of health care } \\
\text { expenditures financed out of private health insurance and degree of market concentration. }\end{array}$ \\
\hline \multicolumn{2}{|l|}{ 2. Providers } \\
\hline 2.1 Degree of private provision & Breakdown of physicians and hospital services according to their nature (public or private). \\
\hline 2.2 Volume incentives embedded in provider payment schemes & Physician and hospital payment modes scored according to incentives to generate volume of services. \\
\hline 2.3 Regulation of prices billed by providers & Regulation of drug prices and of prices billed by physicians and hospitals. \\
\hline 2.4 User information on quality and prices & User information on quality and prices of various health care services. \\
\hline 2.5 Regulation of the workforce and equipment & $\begin{array}{l}\text { Quotas for total number of medical students and by speciality; regulation of practice location; policies to address perceived shortages; regulation of } \\
\text { hospital high-tech equipment and activities (number of hospitals, number of beds, specific services, high cost medical equipment) and control of } \\
\text { recruitment and remuneration of hospital staff. }\end{array}$ \\
\hline 2.6 Patient choice among providers & Degree of freedom in choosing among primary care physicians, specialists and hospitals. \\
\hline \multicolumn{2}{|l|}{ 3. Users } \\
\hline 3.1 Patient choice among providers & Degree of freedom in choosing among primary care physicians, specialists and hospitals. \\
\hline 3.2 Gate-keeping & Obligation or incentive to register to a GP and/or to get referrals to access secondary care. \\
\hline 3.3 Price signals on users & Extent to which patients face out-of-pocket expenses (cost-sharing and "over-the-counter"). \\
\hline \multicolumn{2}{|l|}{ Coverage principles to promote equity } \\
\hline \multicolumn{2}{|l|}{ 4. Level of insurance coverage } \\
\hline 4.1 Breadth - population covered & Proportion of the population covered by basic health insurance. \\
\hline 4.2 Scope of basic coverage & Range of goods and services covered by basic health insurance. \\
\hline 4.3 Depth of coverage & $\begin{array}{l}\text { Level of the costs covered for key goods and services included in the basic benefit package, actual level of coverage by health insurance (including } \\
\text { PHIs) and out-of-pocket payments for essential care. }\end{array}$ \\
\hline \multicolumn{2}{|l|}{$\begin{array}{c}\text { Budget and management approaches to control public } \\
\text { spending }\end{array}$} \\
\hline \multicolumn{2}{|l|}{ 5. Setting and sharing the spending envelope } \\
\hline 5.1 Priority setting & $\begin{array}{l}\text { Definition of the health benefit basket; criteria taken into account in defining it; effective use of health technology assessments (HTA); definition and } \\
\text { monitoring of public health objectives. }\end{array}$ \\
\hline 5.2 Stringency of the budget constraint & Rules and/or targets to fix the health budget and its allocation across sub-sectors and/or regions. \\
\hline 5.3 Regulation of the workforce and equipment & $\begin{array}{l}\text { Quotas for total number of medical students and by speciality; regulation of practice location; policies to address perceived shortages; regulation of } \\
\text { hospital high-tech equipment and activities (number of hospitals, number of beds, specific services, high cost medical equipment) and control of } \\
\text { recruitment and remuneration of hospital staff. }\end{array}$ \\
\hline 5.4 Regulation of prices paid by third-party payers & Regulations of prices paid by third-party payers for primary care physicians, specialists, hospital services and drugs. \\
\hline \multicolumn{2}{|l|}{ 6. Decentralisation and delegation } \\
\hline 6.1 Degree of decentralisation to sub-national governments & Number of key decisions taken at a sub-national government level. \\
\hline 6.2 Degree of delegation to insurers & Number of key decisions taken at the insurer level. \\
\hline 6.3 Consistency in responsibility as & Number of decisions falling under the responsibility of more than one \\
\hline
\end{tabular}




\section{Market signals and regulations affecting users}

37. Some countries have relied extensively on price signals for users, i.e. requiring patients to pay for a significant share of the costs through out-of-pocket payments. However, increasing out-of-pocket payments can lower demand not only for health care services of limited value, but also for necessary services, reducing the chance of early diagnoses and risking higher future care costs (OECD, 2004). Inequity has also been a cause of concern as at least some disadvantaged patients will suffer catastrophic financial or health effects if charges are not capped (Smith, 2008b).${ }^{26}$ Out-of-pocket payments accounted for over 30\% of total health care spending in Greece, Korea, Mexico and Switzerland and less than 7\% in France, Luxembourg and the Netherlands (Figure 10, Panel A).

Figure 10. Market signals and regulations impacting on users' behaviour
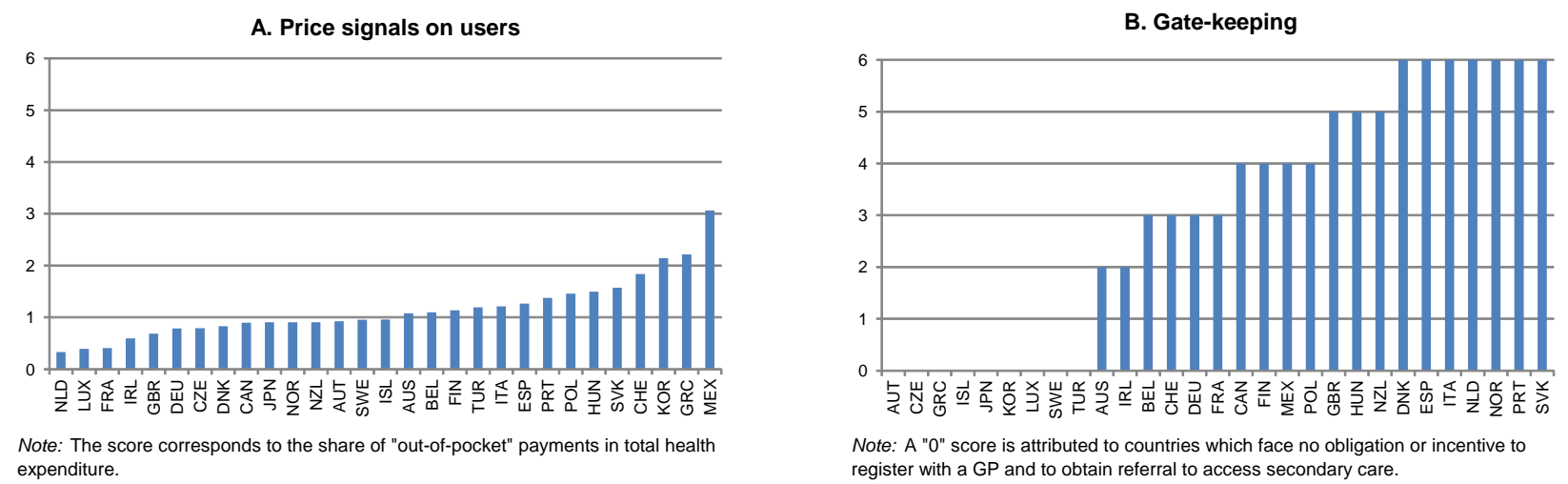

C. Patient choice among providers

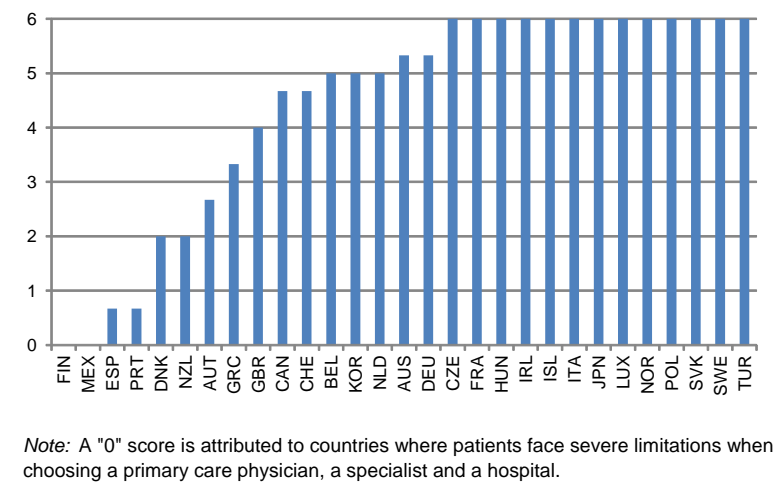

Source: OECD Survey on Health Systems Characteristics 2008-2009; OECD Health Data 2009.

38. To steer patient demand, many countries have also relied on gate-keeping - patients are required, or face incentives, to register with a general practitioner (GP) and/or they need a GP's referral to access specialist care - and/or limited patient choice among providers. Figure 10 (Panel B and C) reveals that most countries restrain user choice (e.g. to providers settled in a given geographical area and/or a network

26. The RAND experiment studied health care costs, utilisation and outcomes in the United States between 1974 and 1982. It randomly assigned 5809 persons to insurance plans that either had no cost-sharing, 25\%, $50 \%$ or $95 \%$, with a maximum cap of USD 1000 ; and 1149 persons to a HMO with no cost-sharing. The experiment showed that cost-sharing reduced "appropriate or needed" medical care as well as "inappropriate or unnecessary" medical care. The reduction in use harmed the health status of those who were both poor and sick (Manning et al., 1988). 
of providers) and/or have gate-keeping arrangements - the Czech Republic, Iceland, Japan, Luxembourg, Sweden and Turkey are the exceptions. ${ }^{27}$

\section{Market mechanisms and regulations affecting providers}

39. Enhancing competitive pressures on providers can have a number of positive impacts, such as increasing productivity, reducing costs of providing care and improving the quality of care. There are potentially adverse effects as well, reflecting market imperfections, including the risk of promoting services that are unnecessary and of losing control over public spending. The approaches followed i.e. the mix of market mechanisms and regulations - are very diverse:

- Volume incentives embedded in provider payment schemes have long varied significantly across countries (Simoens and Hurst, 2006). There has been some convergence in policy settings in recent years, as many countries have adopted payment per case for hospitals (Busse et al., 2006) and/or have moved to a mixed physician payment system (combination of fee-for-services and capitation). Still, the Survey reveals that payment schemes for providers embody few incentives to respond to demand for health care services in some countries, including Iceland, Portugal, Spain and Turkey (Figure 11, Panel A). Paying physicians through salaries and hospitals on the basis of a prospective global budget is expected to make providers less responsive to demand than fee-for-services. For out-patient care, the countries relying mostly on wages to compensate both primary and specialist physicians (including Finland, Mexico, Portugal and Sweden) are also among those with the lowest number of consultations per capita. In contrast, reliance on feefor-services and payment per procedure is widespread in Belgium, Canada, France, Germany, Japan and Switzerland, creating strong incentives for providers to adjust to demand, though with a risk of "supply-induced demand" (Delattre and Dormont, 2003; Grignon et al., 2002; OECD, 2004; Shafrin, 2009). ${ }^{28}$

- The regulations of prices billed by providers also shape provider incentives. On the one hand, low prices may trigger a substitution effect and lower the volume of health services as treating patients becomes less lucrative. On the other hand, an income effect may result in more care as physicians attempt to compensate for the income loss. In practice, fee changes in Norway have had little income effect (Grytten, 2008), while in Japan, strict regulation of physician fees has been accompanied by very short and repeated physician consultations (OECD, 2009b). The Survey suggests a wide cross-country variation in the stringency of price and fee regulations (Figure 11, Panel B), with little regulation of providers' prices in Australia, Germany and Mexico and frequent under-the-table payments, which are by definition unregulated, in Greece and Hungary.

- Regulations of the health workforce and equipment have been used intensively in some countries. The Survey reveals that many governments cap the number of medical students and their mix by specialty, regulate practice location or the opening of new hospitals, while addressing perceived shortages and regional imbalances. Canada, Italy and Turkey intervene most while Iceland and Korea are located at the other extreme (Figure 11, Panel C). It should be noted, however, that there is only a weak correlation between the degree of regulation of the physician workforce and

27. In the absence of regulatory constraint, user choice may still be restricted de facto by geographical constraints - in those regions where the distance to alternative providers is long - and/or by the limited number of providers.

28. The so-called physician-induced demand arises when patients are poorly informed and do not know how much health care they need while doctors have an incentive to push patients to consume more to boost their incomes. 
either the number of physicians per capita or the growth in the number of physicians over recent years.

- By increasing rivalry among suppliers, the degree of private provision in both the inpatient and outpatient care sectors strengthens competitive pressures, potentially reducing costs of provision, improving quality and fostering innovation (OECD, 2006b; Ennis, 2006). In the presence of market failures, however, such positive developments may not materialise. The Survey shows that the share of private hospital beds in the total number of acute care beds varies greatly across countries. It is virtually non-existent in some countries (including Canada, Denmark, Iceland, Norway, Poland, Sweden and the United Kingdom) and is above 50\% in Belgium, Germany, Japan, Korea and the Netherlands. The indicator on the degree of private provision combines this information with information on the predominant mode of provision for different types of physician services (Figure 11, Panel D).

- Providing patient choice among providers enhances consumer empowerment and stimulates competition. It thus strengthens incentives to improve quality and/or contain prices. Many countries have recently increased patient choice over where and by whom they will be treated (including Norway, Sweden and the United Kingdom). Still, the Survey reveals that patient choice among providers is very limited, if existing at all, in several countries, including Finland, Mexico, Portugal and Spain (Figure 11, Panel E).

- Improved user information on the quality and prices of health care services should reinforce competitive pressures by helping users to choose the most effective providers and thus motivate performance improvements. ${ }^{29}$ Ample information may also be important where user choice is limited because purchasers and users can benchmark providers and push for an improvement in case of poor performance - i.e. yardstick competition. The difficulty in understanding the information may, however, limit its use, as seems to have been the case in the United States (Hurst, 2002; Hanoch et al., 2009). Overall, the Survey suggests that user information on prices is still limited in some of the countries where providers do not apply the same price (including Belgium, the Netherlands, New Zealand and Turkey). Also, there is virtually no information on the quality of services of individual providers in the majority of OECD countries (Figure 11, Panel F).

\section{Market signals and incentives affecting insurers}

40. The availability of several publicly or privately financed options for basic health coverage increases consumer choice and thus competitive pressures. The higher the degree of user choice for basic coverage, the higher the pressures to adapt to consumer preferences (Colombo and Tapay, 2004) and to adopt new medical technologies (Dormont et al., 2007). But multi-payer systems may also come with costs compared with an integrated system of financing (OECD, 2004): they may entail a loss of monopsonistic power for payers when negotiating with providers; ${ }^{30}$ they may result in higher administrative costs (Woolhandler et al., 2003); they may generate frustration among people when choice becomes overly complex (Hanoch et al., 2009); and they may make it difficult to maintain equity in access and in financing. These have been important reasons for the Integration Reform in Korea which merged a large number of insurance companies into a single payer in July 2000 (OECD, 2003). In addition, individual

29. In the United Kingdom, Primary Care Trusts have been obliged to offer most patients a choice among hospitals. To help patients make effective choice, "NHS Choices" is a website that facilitates comparisons by providing information on items, such as waiting times, re-admission rates, as well as comments and ratings by patients $(\mathrm{OECD}, 2009 c)$.

30. In the United States, however, private health insurers have been quite active in negotiating with providers, in particular in the context of managed care initiatives (OECD, 2004). 
switching among insurers has often been limited by high transaction costs, a lack of portability of coverage and the absence of comparative information on insurers' performance.

Figure 11. Market signals and regulations impacting on providers' behaviour

A. Providers' incentive to raise the volume of care

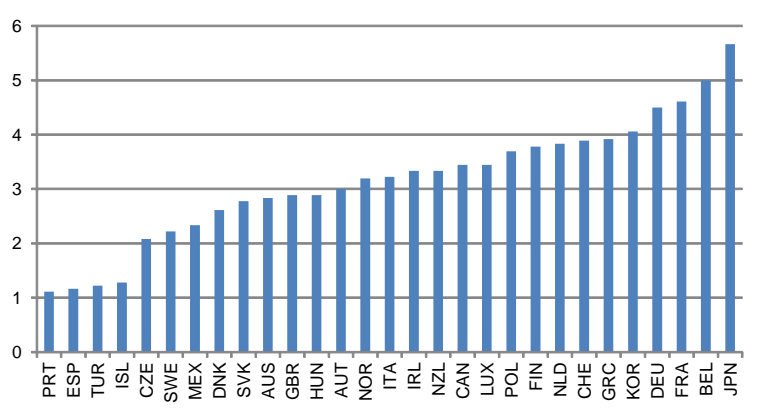

Note: A low score indicates that compensation systems for providers create few incentives to increase volumes of care (e.g. wages for physicians and global budget for hospitals).

C. Regulations of health workforce and equipment

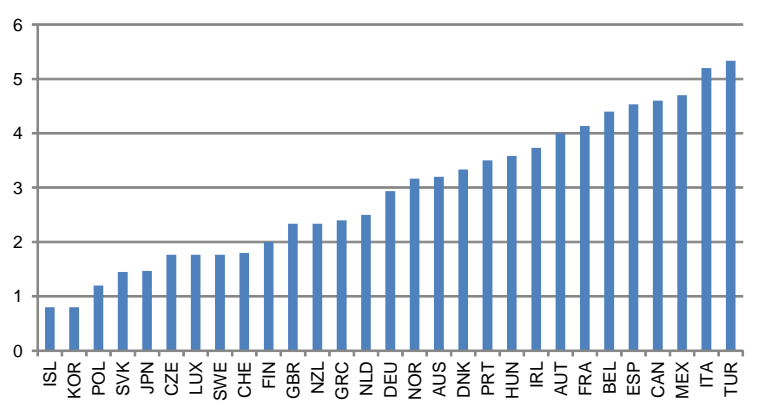

Note: A low score reflects low levels of regulation on in-patient high-tech equipment, activities and staff as well as out-patient physicians.

E. Patient choice among providers

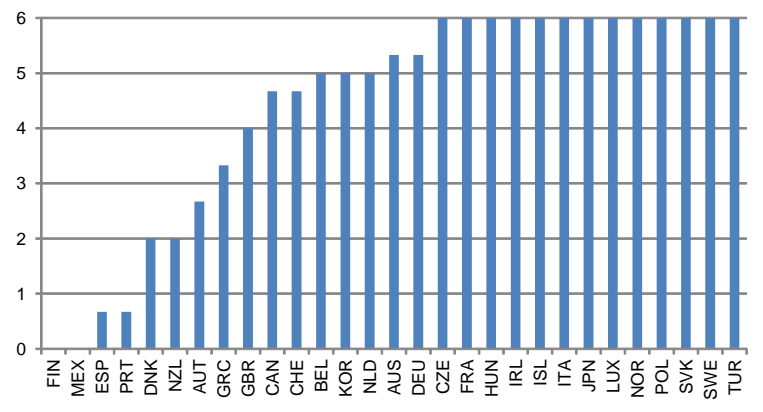

Note: A "0" score is attributed to countries where patients face severe limitations when choosing a primary care physician, a specialist and a hospital.

Source: OECD Survey on Health Systems Characteristics 2008-2009.
B. Regulation of prices billed by providers

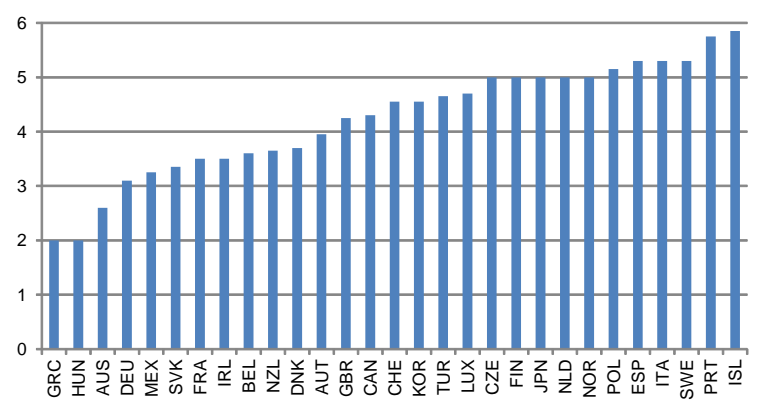

Note: A low score is attributed to countries with few regulations on drug prices and prices billed by physicians and hospitals.

D. Degree of private provision

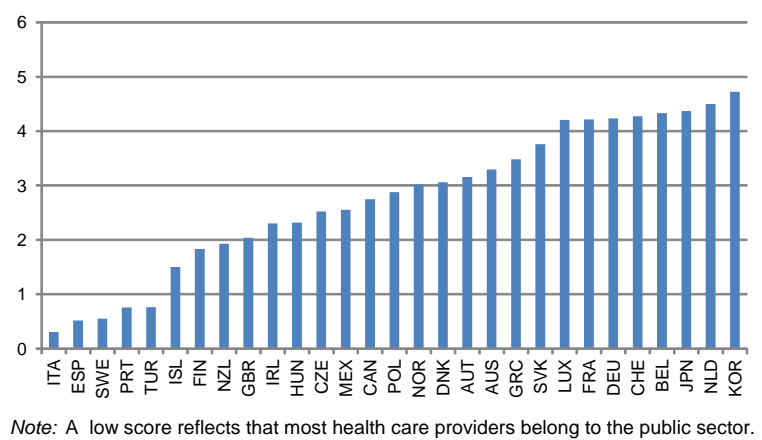

F. User information on quality and prices

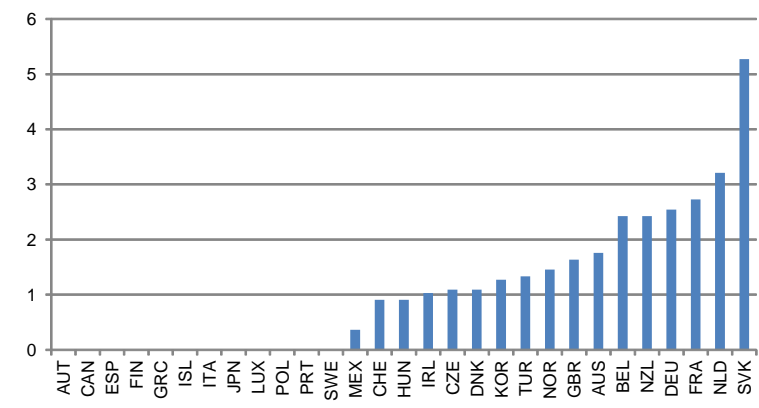

Note: A "0" score is attributed to countries where information on the quality of care and on prices allows patients and/or purchasers to discriminate among providers.

41. Some countries have introduced user choice for basic insurance coverage or strengthened competition across insurers since the early 1990s. The Czech Republic, Germany, the Netherlands, the Slovak Republic and Switzerland are clear cases. ${ }^{31}$ Still, the Survey shows (Figure 12, Panel A) that in most OECD countries, competition is virtually inexistent, as citizens have no choice among insurers for

31. In Switzerland, free choice of insurer and open enrolment were introduced in 1996. In 2007, the Parliament decided to refine the risk equalisation scheme. This amendment will come into force in 2012. 
basic coverage (e.g. NHS countries and countries with a unique social insurance system). In some countries (e.g. France, Greece, Japan and Spain), the basic health coverage is linked to employment status or set at the regional/local level and, although there is no formal market, yardstick competition may arise.

42. Those countries with wide user choice have, in addition, relied on levers for competition on basic insurance to varying degrees. Competition tends to be stronger if insurers can adjust the benefit basket, depth of coverage and/or premia and can negotiate and contract with providers. In the Netherlands, for instance, the selective contracting clause, which allows health insurers to select health care providers and negotiate with hospitals and pharmaceutical companies, is considered as a central pillar of the recent market-oriented health reform (RIVM, 2008; Leu and Matter, 2009). In those countries where there is competition in the basic insurance market, fair competition is underpinned by risk-adjustment schemes between insurance pools with a low risk and a high risk population, and competition is strengthened by the availability of information on insurance packages. The Survey confirms that levers for competition in the insurance market for basic coverage are virtually inexistent in most OECD countries (Figure 12, Panel B).

43. The share of both the population and spending covered by private insurers, over and above the "basic" insurance package - "over-the-basic" coverage - affects the intensity of market pressures in the health insurance market. Canada and France stand out in this respect, with more than two thirds of the population covered, private health insurance spending accounting for over $10 \%$ of total health expenditure and a rather low degree of market concentration (Figure 12, Panel C).

Figure 12. Market signals and regulations impacting on insurers' behaviour

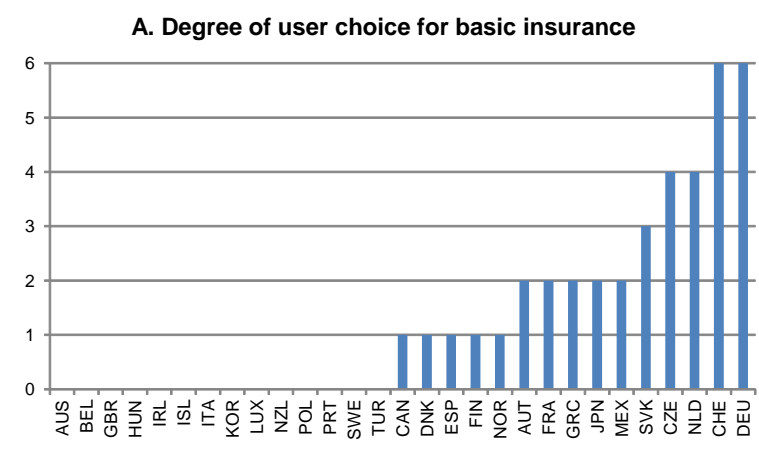

Note: A "0" score is attributed to countries with a single national scheme (NHS or single-payer system).
B. Levers for competition on basic insurance

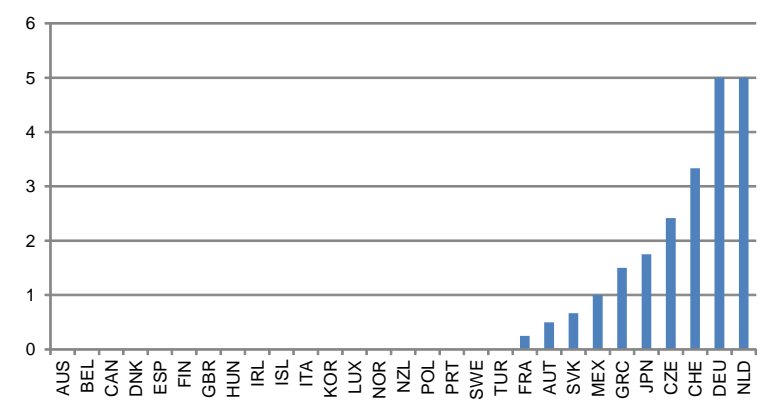

Note: A "0" score is attributed to countries with a single national scheme (NHS or single-payer system) or to countries with multiple schemes but no degree of freedom to change the scope, premium, etc. for the basic insurance package.

C. "Over the basic" coverage: market forces

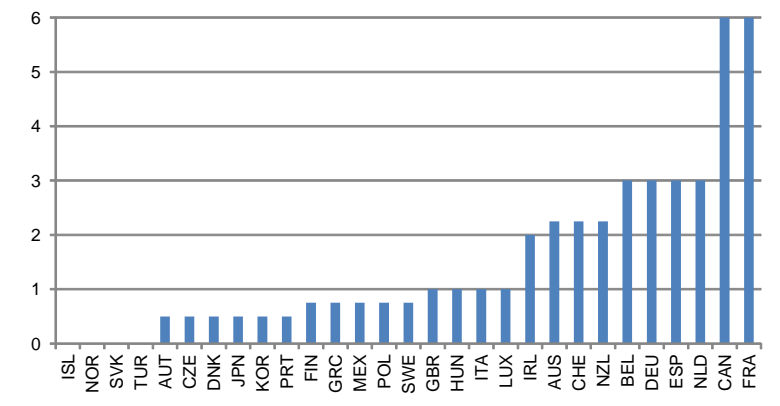

Note: Countries are given a higher score when the share of $\mathrm{PHI}$ in total expenditure is high, when the share of the population covered by a PHI is high and when the degree of market concentration is low.

Source: OECD Health Data 2009; Survey on Health Systems Characteristics 2008-2009. 


\section{Overall, countries rely on different mixes of regulations and market instruments}

44. To assess how regulations and market mechanisms steering the demand and supply of health care services are combined within countries and to identify those which most differentiate countries, a principal component analysis (PCA) has been conducted (Annex 5 provides technical details on the PCA). The PCA reveals that the main dimension differentiating countries is the degree of reliance on regulations, which corresponds to the horizontal axis (Figure 13, Panel A). Gate-keeping arrangements and regulations of health care resources and prices have the highest weights for the first principal component, while the degree of user choice among providers appears with a high but negative weight (Table 5) - those countries relying most on regulation tend to offer users little choice among providers. Countries which lie on the right side of Figure 13 (Panel B) are those with a high intensity of regulation - Portugal and Spain appear as highly regulated countries with very limited or no choice of providers.

Table 5. Reliance on market mechanisms and regulations to steer the demand and supply of health care: results of a PCA

\section{Eigenvalue}

Share of the variance explained (\%)

Cumulative share of the variance explained (\%)

Eigenvectors

Choice of insurers

Insurer levers

Over-the-basic coverage

Private provision

Volume incentives

Regulation of provider prices

User information

Regulation of the workforce and equipment

Choice among providers

Gate-keeping

Price signal on users

\begin{tabular}{crrrr}
\multicolumn{5}{c}{ Principal components } \\
\hline 7.7 & 2 & 3 & \multicolumn{1}{c}{4} & \multicolumn{1}{c}{5} \\
29.8 & 6.6 & 3.6 & 2.7 & 1.9 \\
29.8 & 25.5 & 14.1 & 10.5 & 7.2 \\
& 55.4 & 69.5 & 80.0 & 87.2 \\
-0.24 & 0.53 & -0.40 & -0.09 & 0.31 \\
-0.22 & 0.40 & -0.28 & -0.11 & 0.28 \\
0.01 & 0.31 & 0.27 & 0.68 & 0.17 \\
-0.28 & 0.28 & 0.01 & 0.09 & -0.51 \\
-0.18 & 0.19 & 0.09 & 0.18 & -0.38 \\
0.04 & -0.12 & -0.06 & -0.22 & 0.34 \\
-0.05 & 0.31 & 0.24 & -0.18 & -0.21 \\
0.23 & 0.03 & 0.15 & 0.44 & 0.36 \\
-0.51 & -0.02 & 0.70 & -0.28 & 0.30 \\
0.68 & 0.48 & 0.30 & -0.35 & -0.04 \\
0.03 & -0.02 & -0.13 & -0.01 & -0.11 \\
\hline
\end{tabular}

Source: OECD calculations

45. The degree of reliance on market mechanisms to steer the behaviour of insurers and health care providers is the second main dimension differentiating countries. The second principal component (corresponding to the vertical axis) is mainly driven by the degree of competition in insurance markets (choice of insurers and insurance levers for the basic coverage package as well as market forces on the "over the basic" segment) and in provider markets (degree of private provision, volume incentives for providers and user information). The PCA thus suggests that countries most often combine various market instruments. Countries which lie in the upper part of Figure 13 (Panel B) are those with a high intensity of market forces on the provider and insurance markets. France, Germany, the Netherlands, the Slovak Republic and Switzerland are clear examples. 
Figure 13. Reliance on market mechanisms and regulations to steer the demand and supply of health care Results of a principal component analysis

\section{Panel A. Correlation circle ${ }^{1}$}

Reliance on market mechanisms

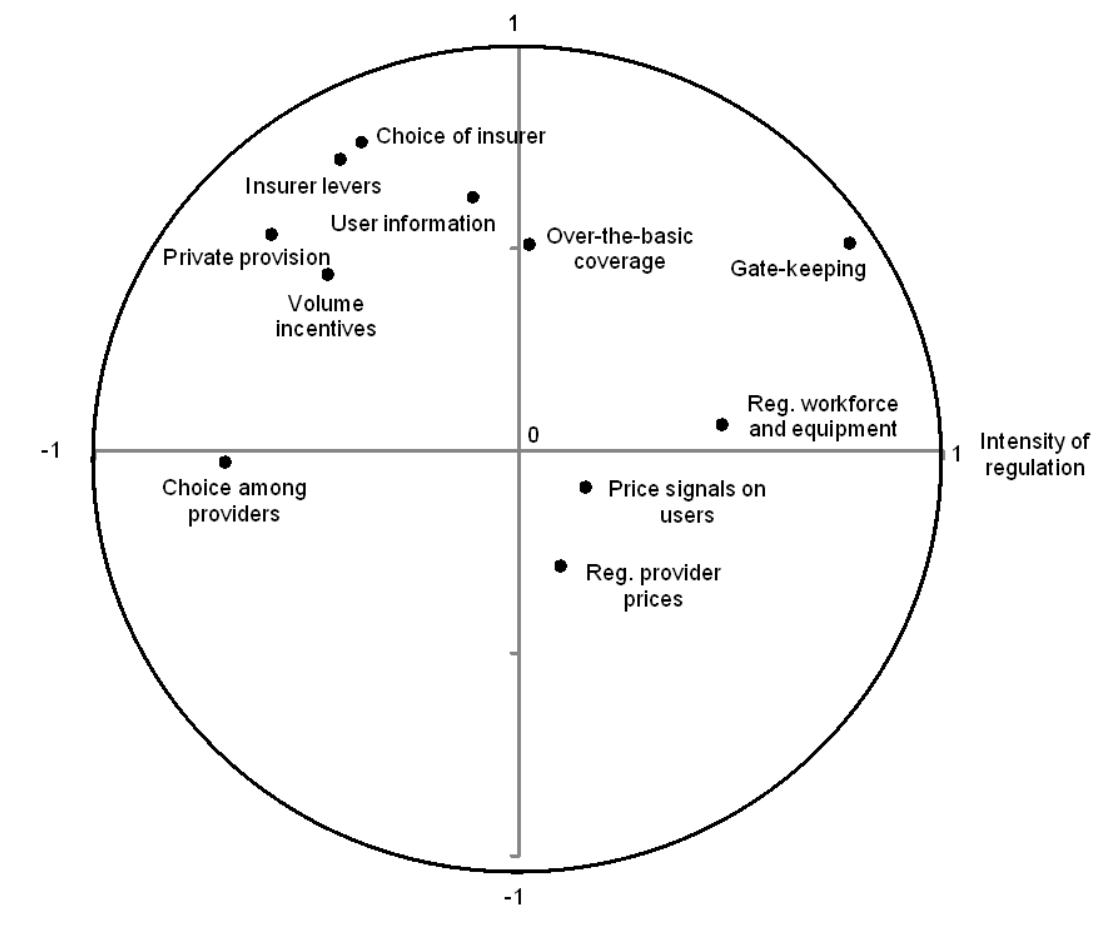

Panel B. Country relative position ${ }^{2}$

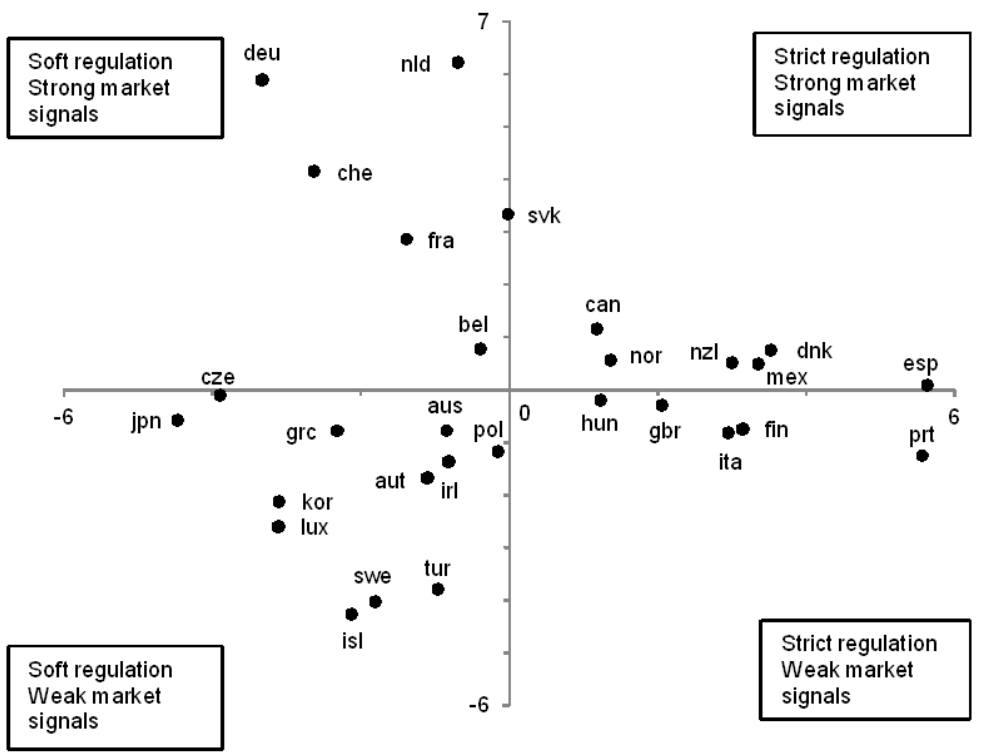

1. The axes of the chart correspond to the first two factors of the PCA, i.e. those that explain the greatest part of the cross-country variance of the policy instruments. The values on the horizontal (resp. vertical) axis correspond to the correlation coefficients with the first (resp. second) factor of the PCA.

2. The values on the horizontal axis (resp. vertical) comespond to weighted averages of the policy instruments, the weights being determined by the eigenvector associated with the first (resp. second) factor of the PCA. Source: OECD Survey on Health Systems Characteristics 2008-09. 
46. The PCA also suggests that the degree of reliance on price signals for users hardly helps differentiating countries when due account is taken of other regulatory and market approaches. The variable is located very close to the centre of the circle (Figure 13, Panel A), signalling very weak correlations with the first two principal components which account for more than half of the variance. ${ }^{32}$ And its weights on the next three main principal components are very low (Table 5). In practice, the level of out-pocket payments is low in many countries giving extensive choice to users, e.g. the Czech Republic, France, Germany and Luxembourg but high in several others (including Korea, the Slovak Republic and Switzerland). Put differently, market mechanisms to discipline providers (including user choice, private provision and compensation systems which create incentives to increase volume of care) are not systematically accompanied by market mechanisms to discipline demand (price signals on users) or gatekeeping arrangements. This may suggest that, when setting user fees, political economy, fiscal and/or equity considerations play a greater role than willingness to ensure consistency in policy settings.

47. While market-based and regulatory approaches are often presented as two distinct models, in practice they are more often combined than used in isolation. Some of the countries relying intensively on regulation also use market instruments to steer the demand and supply of health care services. Still, the mix of market instruments and regulations displays significant cross-country variation:

- Germany, the Netherlands and Switzerland all rely intensively on market mechanisms for managing both the basic coverage package and the supply of services. But the Netherlands regulates prices billed by providers more tightly than the others.

- Canada and France also rely heavily on market mechanisms in managing the supply of health care services and health insurance, but only for the "over-the-basic" coverage, and rely on regulations simultaneously, though more for the health workforce and equipment than for provider prices.

- In Iceland, Sweden, and Turkey, competitive pressures are weak - private provision and incentives for providers to respond to the demand are rather limited. Users are given an extensive choice among providers but regulation of provider prices is strict.

- Denmark, Finland, Mexico, Portugal and Spain are countries characterised by a monolithic, command-and-control, approach - little private provision, no choice of providers, little incentive for providers to respond to demand and strict gate-keeping.

- The other countries rely on a mix of relatively soft regulation and low competitive pressures for providers.

\section{Mitigating inequalities in health care access: indicators on health care coverage}

48. Adequate access to essential health care services has long been a health policy goal in virtually all OECD countries. The comprehensiveness of insurance coverage is a key factor shaping access to health care services by disadvantaged groups. It largely depends on three key dimensions:

- The breadth of basic insurance coverage. OECD countries have now achieved close to universal coverage of the population for a core set of health services. Among the 29 OECD countries which responded to the Survey, Mexico and Turkey are exceptions (Figure 14, Panel A). ${ }^{33}$

32. Changing the coding system for the variable price signals on users - so as to magnify its dispersion by giving the maximum score of 6 to the country with the highest out-of-pocket payment to spending ratio and adjusting the other country scores consistently - does not alter this result.

33. Turkey has been moving towards universal, contributory social health insurance for many years and has now achieved that goal in legislation passed in April 2008 (OECD, 2008). 
- The scope of basic coverage. In virtually all the 29 countries covered, acute in-patient care, consultations for out-patient general practitioners and specialists, clinical laboratory tests as well as diagnostic imaging are included in the basic insurance package - Ireland is the exception as visits to GPs in the out-patient care sector are not covered by the basic package. Several countries exclude eyeglasses, dental care and dental prostheses from the basic coverage (Australia, Canada, Ireland, New Zealand and Norway) or some of these (Denmark, Finland, Italy, Japan, Korea, Mexico, Netherlands, Spain, Sweden, Switzerland and the United Kingdom). Overall, however, eyeglasses, dental care and dental prostheses account for a rather small share of total health care spending and the data suggest that there is very limited variation in the scope of basic coverage across OECD countries (Figure 14, Panel B).

- The depth of insurance coverage. Costs of in-patient and out-patient care are fully covered by the basic package in 11 countries while in several others out-patient care costs are covered at between 51 and $75 \%$. Coverage by complementary, supplementary and/or duplicative insurance further contributes to reducing the level of out-of-pocket payments in several countries (in particular Canada, France, Ireland and Switzerland) ${ }^{34}$ Overall, the depth of insurance coverage is lowest in Greece, Korea, Mexico, Switzerland and Turkey and highest in Germany, the Netherlands and the United Kingdom (Figure 14, Panel C).

Figure 14. Health insurance coverage

A. Breadth

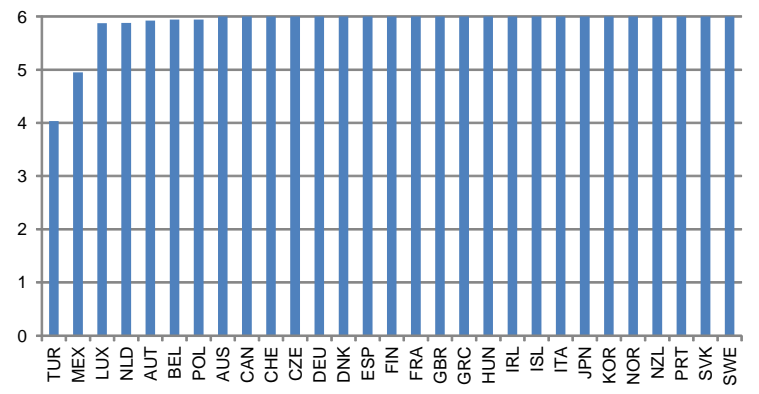

Note: The breadth of coverage reflects the proportion of the population covered by basic health insurance.
B. Scope of basic coverage

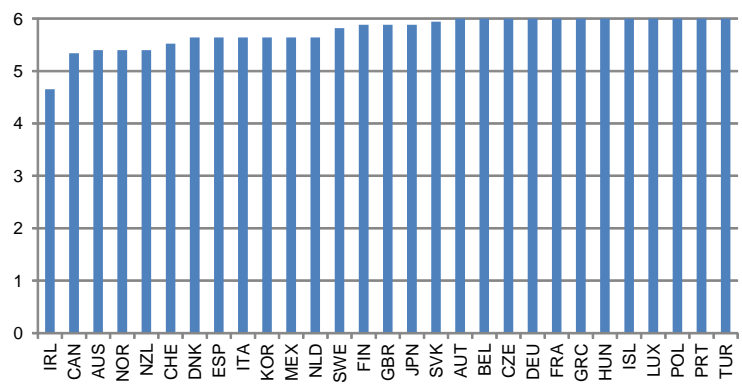

Note: The scope of basic coverage represents the range of goods and services covered by basic insurance.

C. Depth

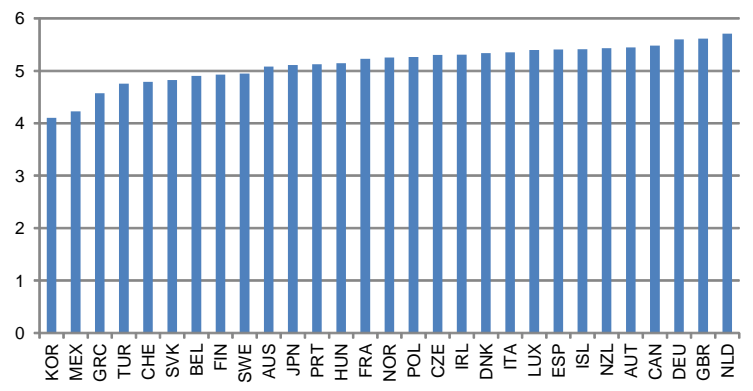

Note: The depth of coverage represents the level of the costs covered for key goods and services included in the basic benefit package, the actual level of coverage by health insurance (public and private) and out-of pocket payments for essential care.

Source: OECD Survey on Health Systems Characteristics 2008-2009.

34. Almost $90 \%$ of the French population benefits from a complementary private health insurance to cover cost-sharing in the social security system and private insurances finance more than $13 \%$ of total health expenditure. The Netherlands and Canada have a large supplementary insurance market whereby private insurance pays for items that are not included in the basic coverage. Duplicative insurance provides faster access to medical services where there are waiting times in public systems. These markets are largest in Ireland, Australia and New Zealand (OECD, 2009a). 


\section{Containing public spending: indicators on budget and management approaches}

49. The sustainability of public spending on health care has become, and continues to be, a pressing policy issue in most countries. The following indicators cover two key aspects, the features for the setting and sharing of the spending envelope and the degree of decentralisation and delegation of decision-making.

Setting the budget envelope, prices and volumes

50. To contain spending pressures, countries have adopted a variety of instruments. Some have tightened the stringency of the budget constraint, imposing caps on health spending either overall or by sector. The Survey shows that budgetary caps and controls have been widely used, in particular in countries where health care delivery is mainly a public sector responsibility (for instance, in New Zealand, Norway, Poland, Portugal, Sweden and the United Kingdom). In contrast, Austria, Japan, Korea and Switzerland do not impose a constraint on public spending on health via the budget process (Figure 15, Panel A). Regulations of prices paid by third-party payers and of the health workforce and equipment have also been used (Figure 15, Panels C and D). As an example, Belgium has set an aggregate budget cap since the mid1990s to determine the global budget, complemented by budgetary targets for sub-sectors. Corrective measures - such as adjustment of fees and reimbursement rates - are taken when there is a risk of overrun (OECD, 2005b). Another, and sometimes complementary, approach has been to reinforce the setting of priorities (Figure 15, Panel B) - in particular through an effective use of health assessment technologies and well-defined criteria for the scope of the benefit basket.

Figure 15. Budget and management approaches - Setting and sharing the spending envelope

A. Stringency of the budget constraint

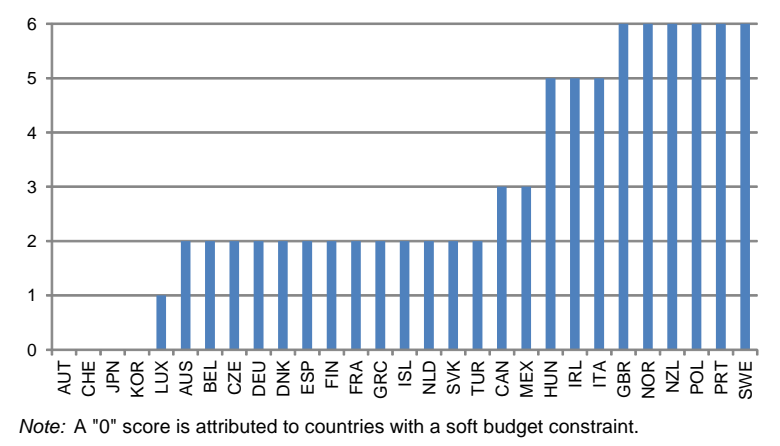

C. Regulation of health workforce and equipment

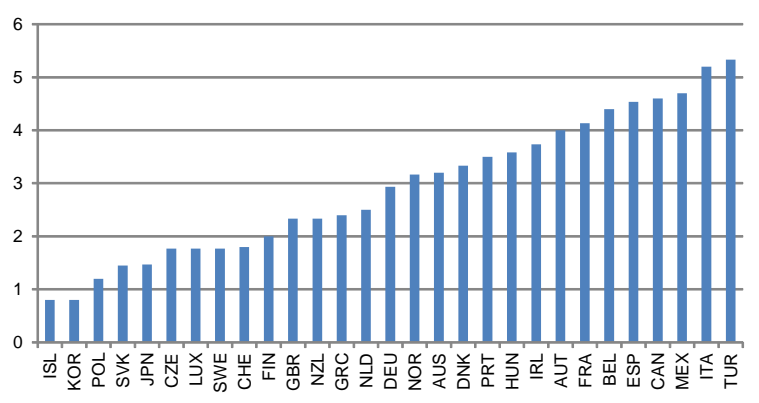

Note: A low score reflects low levels of regulation on in-patient high-tech equipment, activities and staff as well as out-patient physicians.
B. Setting of priorities

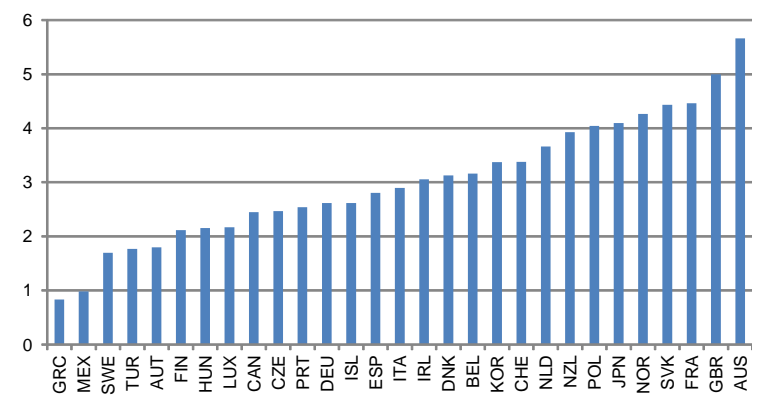

Note: The scores reflect whether a health benefit basket is defined, the criteria taken into account to define it, the definiton and monitoring of public health objectives.

D. Regulation of prices paid by third-party payers

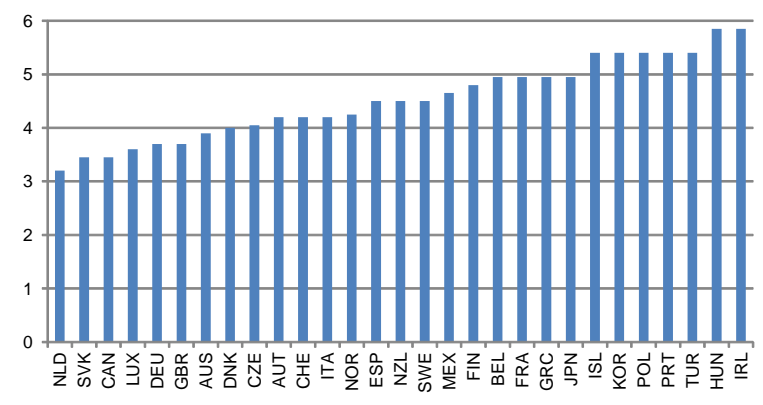

Note: A low score is attributed to countries with few regulations on prices paid by thirdparty payers for primary care physicians, specialists and hospital services. 


\section{The distribution of responsibilities across levels of government or bodies}

51. The allocation of health care responsibilities across government levels and/or to insurers shapes the degree of control over public spending on health care. Decentralisation could raise the responsiveness of the health care system to local needs, stimulate competition across jurisdictions and promote experimentation. ${ }^{35}$ On the other hand, decentralisation might also result in undue institutional complexity, waste through duplication, lax control over spending when responsibilities overlap and insufficient exploitation of economies of scale (Diderichsen, 1995; Joumard and Kongsrud, 2003). ${ }^{36}$ A few countries have recently transferred some responsibilities to sub-national governments (e.g. Italy and Spain) but many others (including Denmark, Ireland, Norway and Poland) have recentralised health care responsibilities (Bach et al., 2009; Saltman, 2008).

52. The degree of decentralisation/delegation in decision-making over key health policy issues is shown in Figure 16 (Panel A). It reflects the actual decision autonomy of sub-national governments on key health care spending issues (including setting remuneration methods for providers and financing new health care facilities). It is the highest in Canada, Finland, Spain, Sweden and Switzerland. ${ }^{37}$ Highly decentralised countries also tend to delegate little decision autonomy to insurers, Switzerland being the main exception (Figure 16, Panel B). The indicator on the degree of consistency in responsibility assignment across levels of governments measures the extent to which responsibilities are clearly defined, allocated consistently and with a minimal degree of overlap (Figure 16, Panel C). The degree of consistency in responsibility assignment declines when several levels of government are involved in key health care decisions (as it is for example the case for financing high-cost equipment in Australia, Canada, the Czech Republic, Denmark, Italy, Japan, Mexico, New Zealand, Poland, Portugal, Sweden, Switzerland and the United Kingdom). It also declines when the assignment of different responsibilities may create inappropriate incentives (e.g. the financing of new hospitals at one government level and the maintenance of existing hospitals at another level, potentially resulting in duplication and/or under-provision and blameshifting).

53. Overall, the stringency of the budget constraint and the degree of decentralisation are the two policy variables that most differentiate countries' budget and management approaches in controlling public spending. The PCA carried out on the subset of variables depicting budget and management approaches further suggests that consistency in responsibility assignment across levels of government tend to be lower in the most decentralised countries - Finland and Spain are exceptions - and that the delegation of responsibilities to health insurers is higher in centralised countries. ${ }^{38}$

35. In Sweden, county councils have significant responsibilities for managing the health care system. They manage hospitals, control the establishment of private practices and set the fees that must be adhered to by private providers to be reimbursed by the social insurance system. Decentralisation is considered to have raised the flexibility of the health care system and made it more innovative (OECD, 2005c).

36. Fragmented decision making and funding arrangements often create cost- and blame-shifting between government levels. The OECD Economic Surveys for Australia and Norway provide examples (OECD, 2006a; OECD, 2002).

37. In most cross-country empirical studies, the degree of decentralisation is measured by the share of public spending of sub-central governments. However, a large spending share may not coincide with true spending autonomy since sub-central government spending may be influenced by central government regulations (Bach et al., 2009). For health care, however, sub-central government spending shares are closely related with the actual decision autonomy of sub-central governments as defined by the Survey.

38. The main results of the PCA are presented in Annex 6. 
Figure 16. Budget and management approaches - Decentralisation and delegation

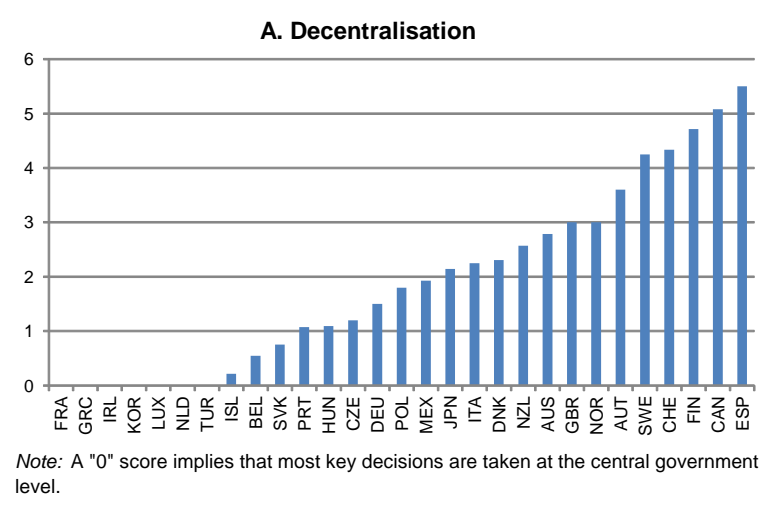

B. Delegation to insurers

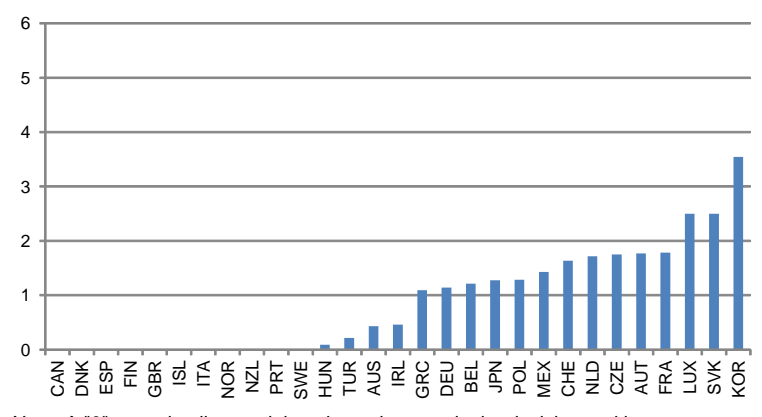

Note: A "0" score implies no delegation to insurers in the decision-making process.

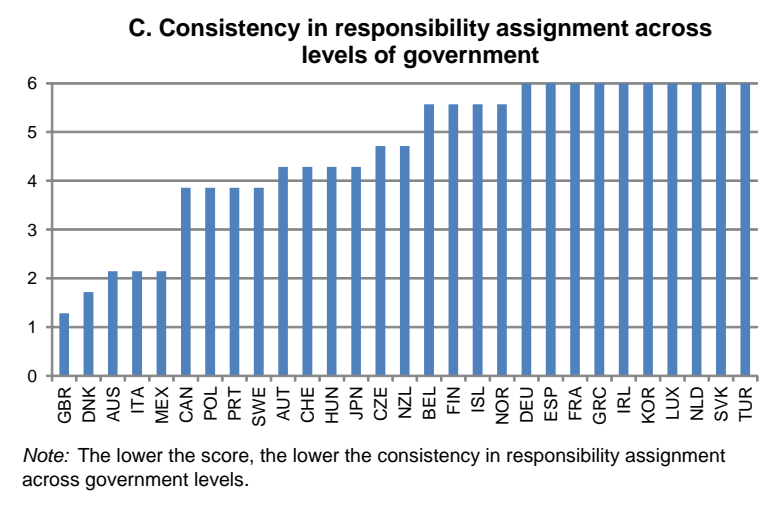

Source: OECD Survey on Health Systems Characteristics 2008-2009.

\section{Using composite indicators would raise tricky issues}

54. Composite indicators can be used to summarise complex and multidimensional issues, a very attractive feature given the richness of the information now gathered on health policies and institutions. But composite indicators also have weaknesses and there are pros and cons for using them, especially for assessing policy issues (Table 6). A limitation of composite indicators is that aggregation methods may have a non-negligible impact on results. This problem can partly be addressed by providing sensitivity analysis.

55. More importantly, additive aggregation implies compensability - poor performance in some indicators can be compensated by sufficiently high values for other indicators (OECD, 2005a). Most composite indicators are built by adding various low-level indicators assuming some substitutability/compensability across them. ${ }^{39}$ In the presence of complementarities across policy instruments, however, there may be no compensation and the impact of a specific institutional feature or policy ultimately depends on scores for other institutional features. In the context of analysing health institutions, the compensability assumption would imply for instance that countries implementing very tight regulations on the number of health care practitioners and very loose regulations on the fees for their services would get, all else equal, a similar score as countries with a more balanced approach in regulating the delivery of health care services. Tight regulations on prices are assumed to compensate (or be a

39. The institutional indicators on education built by the OECD (Gonand et al., 2007) are among the exceptions: the additive approach contains conditionalities and an alternative multiplicative approach has been implemented. 
substitute) for very loose regulations on volumes. This implicit assumption of compensability needs to be challenged: policy instruments interact with each other and cannot be analysed in isolation.

Table 6. Pros and cons of composite indicators

\begin{tabular}{l|l}
\hline \multicolumn{1}{c|}{ Pros } & \multicolumn{1}{c}{ Cons } \\
\hline $\begin{array}{l}\text { - Summarise complex or multidimensional issues in } \\
\text { view of supporting decision-making }\end{array}$ & $\begin{array}{l}\text { May disguise serious failings in some dimensions } \\
\text { and increase the difficulty of identifying remedial } \\
\text { action }\end{array}$ \\
$\begin{array}{l}\text { Are easier to interpret than many separate } \\
\text { indicators }\end{array}$ & $\begin{array}{l}\text { May send misleading policy messages, be } \\
\text { misinterpreted or misused, e.g. to support a } \\
\text { desired policy, if they are poorly constructed or } \\
\text { lack transparency }\end{array}$ \\
$\begin{array}{l}\text { - } \begin{array}{l}\text { Macilitate the task of benchmarking countries } \\
\text { complex issues }\end{array} \\
\begin{array}{l}\text { Place issues of country performance and progress } \\
\text { at the centre of the policy debate } \\
\text { Facilitate communication with the general public } \\
\text { (i.e. citizens, media, etc.) and promote } \\
\text { accountability }\end{array}\end{array}$ & $\begin{array}{l}\text { Invite simplistic policy conclusions and may lead to } \\
\text { inappropriate policies if dimensions of performance } \\
\text { that are difficult to measure are ignored or poorly } \\
\text { represented }\end{array}$ \\
& $\begin{array}{l}\text { The selection of indicators and weights is not } \\
\text { straightforward and could be subject to political } \\
\text { pressures }\end{array}$ \\
& $\begin{array}{l}\text { May make it difficult to account for } \\
\text { complementarities across policies }\end{array}$ \\
\hline
\end{tabular}

Source: Saisana and Tarantola (2002); Smith (2002).

56. An increasing number of studies concludes that a specific institutional feature is not good or bad in itself but should be assessed within a broader institutional context. ${ }^{40}$ As an example of potential complementarities across health institutions, giving users a choice among providers will likely have a different impact on competition depending on whether information on the quality and prices of services is made publicly available. Provider incentives to respond to user needs and preferences will also be higher if the money follows the user, with fees for services being better in this respect than wages. However, in the absence of mechanisms to steer demand (such as gate-keeping and/or out-of-pocket payments), giving users a choice and implementing activity-based payment systems for providers may result in a much higher level of activity, with users "shopping around". It could thus create strong cost pressures with limited effects on health outcomes. ${ }^{41}$

57. While complementarities across institutions are increasingly recognised, they have seldom been systematically identified and analysed. In explaining differences in health system performance across countries, most empirical analyses have focused on one institutional feature - the share of health care

40. On the interactions between institutions in health systems, see Eggleston (2009), Hurst (2002) and Wagstaff (2009). On complementarities and interactions in other economic policy areas, see Braga de Macedo et al. (2009) and Bassanini and Duval (2009) on the labour market.

41. To explain higher efficiency (DEA) scores of German compared with Swiss hospitals, Steinmann et al. (2004) note that "patients in Switzerland, in particular those covered by supplementary health insurance, have a larger choice of hospital without being exposed to cost differences. To the extent that inputs are valued by patients as relevant dimensions of quality, Swiss hospitals must provide them, resulting in excess inputs for a given output." 
spending financed publicly being the feature most often used empirically, though with highly contrasting conclusions. $^{42}$

\section{Characterising health care systems empirically}

58. Various "health care system models", consisting of a set of consistent institutional features, have been identified in the literature (Box 3) but few attempts have been made to produce an empirical characterisation of them - the lack of consistent cross-country data on health care institutions has been an important constraint. ${ }^{43}$ An additional complication is that different features of the various models can coexist (Burau and Blank, 2006), even if one form is dominant. And health systems have evolved over time. Social insurance systems have tended to incorporate features guaranteeing universal coverage, while public-integrated systems have often incorporated some market mechanisms.

59. A key contribution of this paper is to provide an empirical characterisation of health care systems, based on the new and rich OECD dataset on health institutions and policies. This dataset assembles information on incentives and regulations affecting the behaviour of producers, users and insurers and also covers some dimensions often neglected in most other frameworks and typologies, such as the degree of decentralisation in health care policies as well as the comprehensiveness and nature of health insurance coverage. It thus allows going beyond the traditional health care system typologies most often based on financing criteria, such as the public/private funding mix, or the insurance model (Bismarck, Beveridge and private insurance). In terms of methods used, the PCA helps assessing how policy instruments are combined across countries. The cluster analysis then allows identifying groups of countries with comparable policy settings, i.e. characterised by a specific combination of policy instruments. $^{44}$

42. Or (2000) found that the larger the share of health care which is publicly financed, the lower the rates of prenatal and infant mortality. Other characteristics of the health care system, such as the compensation system for health professionals and hospitals, or referral practices, appear to be less important. In contrast, Berger and Messer (2002) found that increases in the publicly-financed share of health care expenditure are associated with higher mortality rates, while Filmer and Pritchett (1997) estimated that the impact of the public spending share is small and insignificant. In an earlier study covering 17 western European countries, Elola et al. (1995) found that countries with a national health service had lower infant mortality rates than countries with a system based on social security.

43. Kotzian (2006), Pommer et al. (2004) and Nixon (2000) are the main exceptions. It should be noted, however, that some work has been carried out to characterise empirically welfare systems - see for instance Bambra (2007) as well as Arts and Gelissen (2002). OECD (2006d) carried out a Principal Component Analysis to derive a synthetic measure of labour market policy settings and performance in OECD countries in the early 2000 s.

44. Wendt (2009) follows a similar approach. Relying on a cluster analysis carried out on 2001 data for 15 European countries for 2001, he identifies three groups of countries plus two outliers (Greece and the Netherlands). Institutional indicators included in the analysis are: the remuneration mode of GPs (with three categories: fee-for-service, capitation, salary), GP registration (two categories reflecting whether or not patients have to sign onto the list of a certain GP), gate-keeping arrangements (four categories), and out-of-pocket payments. 
ECO/WKP(2010)25

\section{Box 3. Health care systems: a wide variety of frameworks and the OECD typology}

As noted by Shakarishvili (2009), "to date, there has been a proliferation of multiple approaches to thinking about health systems". They vary in particular in their focus, scope and taxonomy. ${ }^{1}$ The World Health Organisation (WHO) identified three main goals of health systems in the 2000 World Health Report (WHR): better health, fairness in financial protection and responsiveness to people's expectations (WHO, 2000; Evans, 2002). The Report also focused on four main functions which contribute to attaining these goals: delivering services (provision), financing (collecting, pooling and purchasing), creating resources (investment and training) and stewardship (oversight). The WHO's framework for action (WHO, 2007) proposes a framework with six building blocks: service delivery; health workforce; information; medical products; vaccines and technologies; financing; and leadership and governance (stewardship). The World Bank Institute's Flagship Programme on Health Sector Reform focuses on reform strategies, bundled into five health system "control knobs": financing; payment; organisation; regulation and behaviour. Other approaches, including by the OECD, focus more on actors and interactions between them.

Focusing on relations across providers, payers and users, Docteur and Oxley (2003) and OECD (2004) identified three main "models" of health systems:

1. The public-integrated model combines budget financing of health-care provision with hospital providers that are part of the government sector. ${ }^{2}$ The insurance and provision functions are merged and the system is organised and managed like a government department. The employees are generally salaried (although, in some cases, doctors can have private patients as well) and are most often public-sector employees. Ambulatory doctors and other health-care professionals can be either public employees or private contractors to the health-care authority, with a range of remuneration packages. Ensuring complete population coverage is particularly easy under such systems, and as they face a budget constraint, the growth of overall costs has been contained more easily. However, they have weak incentives to adapt output to demand, improve efficiency, or raise quality and responsiveness to patient needs. This may be less the case in the ambulatory sector, where payment systems are more often linked to provider output.

2. In the public-contract model, public payers contract with private health-care providers. The payers can be either a state agency or social security fund. ${ }^{3}$ Single-payers have a stronger negotiating position vis-à-vis providers (as in the public integrated model) and tend to have lower administrative costs than do multiple payer systems. In many public-contract systems, the private hospitals and clinics operate on a non-profit basis. Independent private contractors generally supply ambulatory care. In the past, payment of providers has been often on an ex post basis, although contract arrangements have been evolving. These systems are generally considered to be more responsive to patient needs than public-integrated arrangements, but less successful in containing health-care costs, requiring additional regulation and control by the public authorities.

3. A private insurance/provider model uses private insurance combined with private (often for-profit) providers. In Switzerland, the insurers have to be not for-profit for compulsory insurance and are for-profit for supplementary insurance; private providers can be for-profit or not for-profit. In the United States, insurance is voluntary and may not be affordable for some individuals. Payment methods have traditionally been activity based, and the systems have featured a high degree of choice and responsiveness to patient needs, but cost control has been weak. In response, managed care plans, which provide incentives for volume and price control, expanded rapidly in the United States during the 1990s. Under these arrangements, insurers selectively contract with competing providers and restrict patient choice of providers and services.

1. Wendt et al. (2009) provide a review of the literature on health care system typologies and propose their own typology with 27 possible models, characterised by three dimensions - financing, provision and regulation of health care - and three categories of actors - the state, non-governmental organisations and private actors.

2. Broadly speaking, public-integrated systems exist in the Nordic countries, Australia (public hospitals), Italy, Greece and Portugal and, before reforms of the early 1990s, the United Kingdom. New Zealand introduced a purchaser-provider split in the 1990s similar to developments in the United Kingdom, but it has since moved closer to an integrated model following reforms in 2000.

3. Canada, most of the remaining continental European countries, Japan, and, now, the United Kingdom and, to some extent, New Zealand, belong to the public-contract category. 


\section{Identifying institutional patterns using principal component analysis}

60. Carrying out a principal component analysis on the full set of indicators on health policies and institutions confirms that the degree of reliance on market mechanisms and regulations to steer the demand and supply of health services is key to characterise health care systems. Adding the indicators depicting budget and management approaches and coverage principles to those on market mechanisms and regulations affecting users, providers and insurers does not change the results of the PCA much (Table 7). ${ }^{45}$ Some variables are strongly correlated with one of the axis identified in the first PCA (e.g. the budget constraint with the regulatory axis). Several indicators vary little across countries (e.g. the scope, breadth and depth of coverage all have a low weight on both axes) and thus provide little information for differentiating countries. Others are largely uncorrelated with all other indicators (e.g. priority setting); they increase the overall variance but do not allow identifying clearly any additional institutional patterns.

\section{Table 7. Results of a PCA on the full set of indicators on health policy and institutions}

\begin{tabular}{|c|c|c|c|c|c|c|}
\hline & \multicolumn{6}{|c|}{ Principal components } \\
\hline & 1 & 2 & 3 & 4 & 5 & 6 \\
\hline Eigenvalue & 11.0 & 7.1 & 5.4 & 3.0 & 2.9 & 2.3 \\
\hline Share of the variance explained (\%) & 28.6 & 18.4 & 14.1 & 7.7 & 7.4 & 6.0 \\
\hline Cumulative share of the variance explained (\%) & 28.6 & 46.9 & 61.1 & 68.8 & 76.2 & 82.2 \\
\hline \multicolumn{7}{|l|}{ Eigenvectors } \\
\hline Private provision & -0.30 & 0.21 & 0.08 & 0.04 & -0.08 & -0.35 \\
\hline Volume incentives & -0.16 & 0.14 & 0.09 & 0.19 & 0.00 & -0.23 \\
\hline Regulation of provider prices & 0.05 & -0.09 & -0.05 & -0.07 & 0.26 & 0.10 \\
\hline User information & -0.09 & 0.27 & 0.29 & -0.14 & -0.17 & -0.09 \\
\hline Regulation of the workforce and equipment & 0.16 & 0.07 & -0.05 & 0.33 & -0.36 & 0.30 \\
\hline Choice among providers & -0.31 & -0.16 & 0.63 & 0.22 & 0.36 & 0.18 \\
\hline Gate-keeping & 0.50 & 0.58 & 0.22 & -0.22 & -0.13 & -0.09 \\
\hline Price signals on users & 0.01 & -0.02 & -0.10 & -0.11 & -0.07 & -0.06 \\
\hline Choice of insurer & -0.27 & 0.45 & -0.18 & -0.19 & 0.27 & 0.32 \\
\hline Insurer levers & -0.23 & 0.33 & -0.06 & -0.21 & 0.21 & 0.34 \\
\hline Over-the-basic coverage & -0.02 & 0.30 & 0.06 & 0.68 & -0.19 & 0.18 \\
\hline Priority setting & 0.01 & 0.15 & 0.28 & 0.09 & 0.16 & -0.39 \\
\hline Budget constraint & 0.46 & -0.11 & 0.43 & -0.12 & 0.17 & 0.28 \\
\hline Regulation of prices paid by third-party payers & 0.02 & -0.16 & 0.02 & -0.03 & -0.16 & 0.04 \\
\hline Decentralisation & 0.24 & 0.14 & -0.36 & 0.36 & 0.51 & -0.08 \\
\hline Delegation & -0.22 & 0.05 & 0.00 & -0.11 & -0.09 & -0.18 \\
\hline Consistency & -0.24 & 0.00 & 0.06 & -0.08 & -0.33 & 0.36 \\
\hline Breadth & 0.00 & 0.04 & 0.03 & 0.03 & 0.07 & -0.08 \\
\hline Scope of coverage & -0.02 & -0.02 & -0.02 & -0.05 & 0.00 & 0.00 \\
\hline Depth & 0.02 & 0.04 & 0.04 & 0.05 & 0.07 & 0.06 \\
\hline
\end{tabular}

Source: OECD calculations

45. The correlations between the country co-ordinates with respect to the first two axes of the PCA using the full set of indicators and those of the PCA based only on market mechanisms and regulation stand at above 0.9 . 
61. Incorporating all the policy indicators into the PCA still provides interesting insights into the structure of health systems. In particular:

- The variables related to the level of coverage do not play an important role in differentiating countries, as most of the 29 OECD countries which responded to the Survey have now achieved close to universal coverage for a core set of health services, the exceptions being Mexico and Turkey. These variables are located near to the centre of the circle (Figure 17, Panel A).

- Those countries relying mainly on command-and-control approaches to steer the demand and supply of health care services - strict regulations on workforce and equipment, mostly public providers, little user choice among providers - also tend to impose limits on public health care spending via the budget process (e.g. through expenditure targets or norms).

- Most decentralised countries tend to regulate health care resources and/or prices more than the OECD average. ${ }^{46}$ A high degree of decentralisation is often associated with a relatively weak consistency of responsibility assignments across levels of governments, suggesting that overlap in responsibilities for health care management tends to be present in decentralised systems.

- Among the countries that are close to the centre of Figure 17 (Australia, Ireland and two of the four Eastern European countries), results should be interpreted with special care. The relative position of Australia and Ireland partly reflects the heterogeneous nature of their health care system. ${ }^{47}$ The relative position of Eastern European countries also could, to some extent, reflect an ongoing reform process (Medved et al., 2005).

\section{Grouping countries with similar institutions using cluster analysis}

62. Cluster analysis can be used to identify groups of countries with similar institutions. While there is always some judgement needed to define the optimal number of clusters because of the trade-off between the number of groups and the degree of heterogeneity within groups, the cluster analysis suggests that OECD countries can reasonably be grouped into six clusters. ${ }^{48}$ These country clusters display the following key institutional features (Figure 18 and Table 8):

- Germany, the Netherlands, the Slovak Republic and Switzerland rely extensively on market mechanisms in regulating the basic insurance coverage. Private providers play an important role

46. Decentralisation is often seen as introducing some form of competitive pressures. Citizens can observe differences in the quality of public services and associated taxes across jurisdictions and "vote with their feet" (Tiebout model) and/or put pressures on their government to improve the effectiveness of the health care system.

47. Wendt (2009) also notes that due to its heterogeneous structure, the Irish health system is difficult to classify.

48. With six groups, the ratio of the between-cluster variance to the total variance is over $50 \%$, as indicated on the horizontal axis (R-squared) of the dendogramme (see Annex 5, Figure A5.1). Increasing the ratio significantly would require a much larger number of groups. Reducing the number of groups to less than six would result in highly heterogeneous clusters. A more formal assessment of the robustness of the cluster analysis can be done by looking at the approximately unbiased (AU) p-values which indicate the confidence level associated with each cluster (Annex 5 provides more detail on cluster analysis and pvalues). All the six country clusters which have been identified show p-values above $80 \%$. 
Figure 17. Indicators on health policy and institutions: results of the PCA

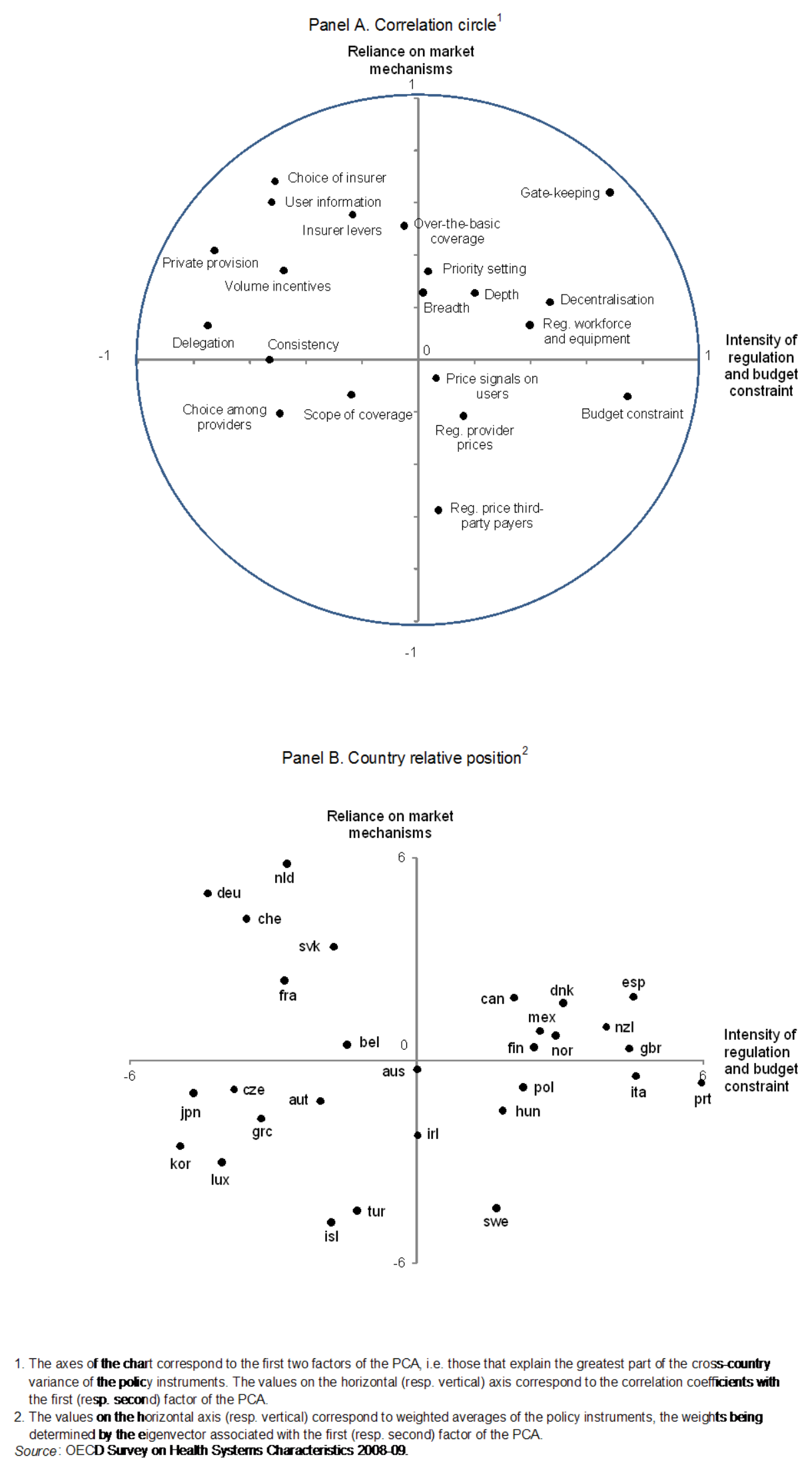


and are mostly paid through fee-for-service schemes. Users are offered ample choice among providers but gate-keeping arrangements are in place. There is no strict spending rule and little reliance on regulation of prices paid by third-party payers to control public spending growth. These countries still differ significantly in the degree of decentralisation: sub-national governments have extensive autonomy in managing health care services in Switzerland, while the Netherlands is at the opposite side of the spectrum.

- A second group of countries - Australia, Belgium, Canada and France - features public basic insurance coverage combined with heavy reliance on market mechanisms at the provider level: users are given a wide choice among providers; private provision of both in-patient and outpatient care is relatively abundant; incentives for providers to produce high volumes of services tend to be important, and user information on quality and prices may act as a disciplining factor. Over-the-basic insurance coverage plays a significant role in these countries. In France and to a lesser extent in Belgium, the basic coverage package imposes significant cost-sharing on users, which is largely covered by complementary insurance. Canada has a large supplementary market (67\% of the population) whereby private insurance pays for prescription drugs and dental care that are not publicly reimbursed. In Australia, over-the-basic coverage both takes the form of supplementary and duplicative private insurance. In this group of countries, cost control generally takes the form of moderate gate-keeping arrangements and strict priority setting arrangements (benefit basket defined at the central government level by a positive list and/or effective use of health technology assessment in determining which goods and services should be included in the basic coverage package).

- The third group - which includes Austria, the Czech Republic, Greece, Japan, Korea and Luxembourg - is also characterised by extensive private provision of care and wide patient choice. But there is no gate-keeping system in place. And the available information on quality and prices is scarce, creating little competitive pressures on providers. Over-the-basic coverage is limited. The budget constraint tends to be less stringent than in other country groups.

- The health care systems of Iceland, Sweden and Turkey offer free choice of provider to patients in all three areas of care - primary, specialist and hospital care - with no gate-keeping. ${ }^{49}$ However, private provision is very limited, suppliers have few incentives to increase volumes and their prices tend to be tightly regulated. The budget constraint is weak, except in Sweden, where it is very strict.

- In the group consisting of Denmark, Finland, Mexico, Portugal and Spain, health care is mainly provided by a heavily regulated public system. Patients' choice among providers is extremely limited and the role of gate-keeping is important. There is a public spending target for health care but no strict budget constraint, except in Portugal. Among these countries, Spain and Finland are clearly more decentralised than the OECD average.

- The last group also consists of heavily regulated public systems - Hungary, Ireland, Italy, New Zealand, Norway, Poland and the United Kingdom. The budget constraint is more stringent than in most other OECD countries. Compared with the previous group, the possibility for patients of choosing between providers tends to be large and sub-national government autonomy tends to be lower. Over-the-basic coverage is very limited, except in Ireland and New Zealand, where duplicative coverage is significant and provides faster private-sector access to medical services.

49. In Iceland and Turkey, user choice among providers may be de facto constrained by geographical factors and/or by the actual number of providers (in Iceland in particular). 
Table 8. Characterising country groups

\begin{tabular}{|c|c|c|c|c|c|c|c|c|c|c|c|c|c|c|c|c|c|c|c|c|}
\hline & $\begin{array}{l}\text { User } \\
\text { choice of } \\
\text { insurer }\end{array}$ & $\begin{array}{l}\text { Insurer } \\
\text { levers }\end{array}$ & $\begin{array}{c}\text { Over-the- } \\
\text { basic }\end{array}$ & $\begin{array}{c}\text { Private } \\
\text { provision }\end{array}$ & $\begin{array}{l}\text { Provider } \\
\text { incentives }\end{array}$ & $\begin{array}{l}\text { Reg. } \\
\text { provider } \\
\text { prices }\end{array}$ & $\begin{array}{c}\text { User } \\
\text { information }\end{array}$ & $\begin{array}{c}\text { Reg. } \\
\text { workforce } \\
\text { and } \\
\text { equipment }\end{array}$ & $\begin{array}{c}\text { Choice } \\
\text { among } \\
\text { providers }\end{array}$ & $\begin{array}{c}\text { Gate- } \\
\text { keeping }\end{array}$ & $\begin{array}{c}\text { User } \\
\text { prices }\end{array}$ & $\begin{array}{l}\text { Priority } \\
\text { setting }\end{array}$ & $\begin{array}{l}\text { Budget } \\
\text { constraint }\end{array}$ & $\begin{array}{l}\text { Reg. price } \\
\text { paid by } \\
\text { third-party } \\
\text { payer }\end{array}$ & $\begin{array}{l}\text { Decentra- } \\
\text { lisation }\end{array}$ & $\begin{array}{c}\text { Dele- } \\
\text { gation }\end{array}$ & $\begin{array}{c}\text { Consis- } \\
\text { tency }\end{array}$ & Breadth & $\begin{array}{l}\text { Scope of } \\
\text { coverage }\end{array}$ & Depth \\
\hline Germany & 6.0 & 5.0 & 3.0 & 4.2 & 4.5 & 3.1 & 2.5 & 2.9 & 5.3 & 3.0 & 0.8 & 2.6 & 2.0 & 3.7 & 1.5 & 1.1 & 6.0 & 6.0 & 6.0 & 5.6 \\
\hline Netherlands & 4.0 & 5.0 & 3.0 & 4.5 & 3.8 & 5.0 & 3.2 & 2.5 & 5.0 & 6.0 & 0.3 & 3.7 & 2.0 & 3.2 & 0.0 & 1.7 & 6.0 & 5.9 & 5.6 & 5.7 \\
\hline Slovak Republic & 3.0 & 0.7 & 0.0 & 3.8 & 2.8 & 3.4 & 5.3 & 1.5 & 6.0 & 6.0 & 1.6 & 4.4 & 2.0 & 3.5 & 0.8 & 2.5 & 6.0 & 6.0 & 5.9 & 4.8 \\
\hline Switzerland & 6.0 & 3.3 & 2.3 & 4.3 & 3.9 & 4.6 & 0.9 & 1.8 & 4.7 & 3.0 & 1.8 & 3.4 & 0.0 & 4.2 & 4.3 & 1.6 & 4.3 & 6.0 & 5.5 & 4.8 \\
\hline Average - Group 1 & 4.8 & 3.5 & 2.1 & 4.2 & 3.8 & 4.0 & 3.0 & 2.2 & 5.3 & 4.5 & 1.1 & 3.5 & 1.5 & 3.6 & 1.6 & 1.7 & 5.6 & 6.0 & 5.8 & 5.2 \\
\hline Australia & 0.0 & 0.0 & 2.3 & 3.3 & 2.8 & 2.6 & 1.8 & 3.2 & 5.3 & 2.0 & 1.1 & 5.7 & 2.0 & 3.9 & 2.8 & 0.4 & 2.1 & 6.0 & 5.4 & 5.1 \\
\hline Belgium & 0.0 & 0.0 & 3.0 & 4.3 & 5.0 & 3.6 & 2.4 & 4.4 & 5.0 & 3.0 & 1.1 & 3.2 & 2.0 & 5.0 & 0.5 & 1.2 & 5.6 & 5.9 & 6.0 & 4.9 \\
\hline Canada & 1.0 & 0.0 & 6.0 & 2.8 & 3.4 & 4.3 & 0.0 & 4.6 & 4.7 & 4.0 & 0.9 & 2.4 & 3.0 & 3.5 & 5.1 & 0.0 & 3.9 & 6.0 & 5.3 & 5.5 \\
\hline France & 2.0 & 0.3 & 6.0 & 4.2 & 4.6 & 3.5 & 2.7 & 4.1 & 6.0 & 3.0 & 0.4 & 4.5 & 2.0 & 5.0 & 0.0 & 1.8 & 6.0 & 6.0 & 6.0 & 5.2 \\
\hline Average - Group 2 & 0.8 & 0.1 & 4.3 & 3.6 & 4.0 & 3.5 & 1.7 & 4.1 & 5.3 & 3.0 & 0.9 & 3.9 & 2.3 & 4.3 & 2.1 & 0.9 & 4.4 & 6.0 & 5.7 & 5.2 \\
\hline Czech Republic & 4.0 & 2.4 & 0.5 & 2.5 & 2.1 & 5.0 & 1.1 & 1.8 & 6.0 & 0.0 & 0.8 & 2.5 & 2.0 & 4.1 & 1.2 & 1.8 & 4.7 & 6.0 & 6.0 & 5.3 \\
\hline Greece & 2.0 & 1.5 & 0.8 & 3.5 & 3.9 & 2.0 & 0.0 & 2.4 & 3.3 & 0.0 & 2.2 & 0.8 & 2.0 & 5.0 & 0.0 & 1.1 & 6.0 & 6.0 & 6.0 & 4.6 \\
\hline Japan & 2.0 & 1.8 & 0.5 & 4.4 & 5.7 & 5.0 & 0.0 & 1.5 & 6.0 & 0.0 & 0.9 & 4.1 & 0.0 & 5.0 & 2.1 & 1.3 & 4.3 & 6.0 & 5.9 & 5.1 \\
\hline Korea & 0.0 & 0.0 & 0.5 & 4.7 & 4.1 & 4.6 & 1.3 & 0.8 & 5.0 & 0.0 & 2.1 & 3.4 & 0.0 & 5.4 & 0.0 & 3.5 & 6.0 & 6.0 & 5.6 & 4.1 \\
\hline Luxembourg & 0.0 & 0.0 & 1.0 & 4.2 & 3.4 & 4.7 & 0.0 & 1.8 & 6.0 & 0.0 & 0.4 & 2.2 & 1.0 & 3.6 & 0.0 & 2.5 & 6.0 & 5.9 & 6.0 & 5.4 \\
\hline Average - Group 3 & 1.7 & 1.0 & 0.6 & 3.7 & 3.7 & 4.2 & 0.4 & 2.0 & 4.8 & 0.0 & 1.2 & 2.5 & 0.8 & 4.5 & 1.2 & 2.0 & 5.2 & 6.0 & 5.9 & 5.0 \\
\hline Iceland & 0.0 & 0.0 & 0.0 & 1.5 & 1.3 & 5.9 & 0.0 & 0.8 & 6.0 & 0.0 & 1.0 & 2.6 & 2.0 & 5.4 & 0.2 & 0.0 & 5.6 & 6.0 & 6.0 & 5.4 \\
\hline Sweden & 0.0 & 0.0 & 0.8 & 0.6 & 2.2 & 5.3 & 0.0 & 1.8 & 6.0 & 0.0 & 1.0 & 1.7 & 6.0 & 4.5 & 4.3 & 0.0 & 3.9 & 6.0 & 5.8 & 4.9 \\
\hline Turkey & 0.0 & 0.0 & $\begin{array}{l}.0 \\
0.0\end{array}$ & $\begin{array}{l}0.6 \\
0.8\end{array}$ & 1.2 & $\begin{array}{l}.3 \\
4.7\end{array}$ & $\begin{array}{l}.0 \\
1.3\end{array}$ & $\begin{array}{l}1.0 \\
5.3\end{array}$ & $\begin{array}{l}0.0 \\
6.0\end{array}$ & 0.0 & $\begin{array}{l}1.0 \\
1.2\end{array}$ & 1.8 & $\begin{array}{l}0.0 \\
2.0\end{array}$ & $\begin{array}{l}4.5 \\
5.4\end{array}$ & $\begin{array}{l}4.3 \\
0.0\end{array}$ & 0.2 & $\begin{array}{l}.5 \\
6.0\end{array}$ & 4.0 & $\begin{array}{l}5.0 \\
6.0\end{array}$ & $\begin{array}{l}4.9 \\
4.8\end{array}$ \\
\hline Average - Group 4 & 0.0 & 0.0 & 0.3 & $\begin{array}{l}0.9 \\
0.9\end{array}$ & 1.6 & $\begin{array}{l}4.1 \\
5.3\end{array}$ & $\begin{array}{ll}1.5 \\
0.4\end{array}$ & $\begin{array}{l}.3 \\
\mathbf{2 . 6}\end{array}$ & $\begin{array}{l}6.0 \\
6.0\end{array}$ & 0.0 & 1.0 & $\begin{array}{l}1.0 \\
2.0\end{array}$ & 3.3 & $\begin{array}{l}5.4 \\
5.1\end{array}$ & $\begin{array}{ll}0.5 \\
1.5\end{array}$ & 0.1 & 5.1 & $\begin{array}{l}4.0 \\
5.3\end{array}$ & $\begin{array}{l}0.0 \\
5.9\end{array}$ & $\begin{array}{l}4.0 \\
5.0\end{array}$ \\
\hline$\frac{\text { A verage - Group } 4}{\text { Denmark }}$ & $\frac{0.0}{1.0}$ & 0.0 & 0.35 & $\frac{0.9}{3.1}$ & $\frac{1.6}{2.6}$ & $\begin{array}{l}3.3 \\
3.7\end{array}$ & $\begin{array}{c}.4 \\
1.1\end{array}$ & 3.6 & $\frac{0.0}{2.0}$ & $\frac{.0}{6.0}$ & 0.8 & 3.1 & $\frac{3.3}{2.0}$ & $\frac{5.1}{4.0}$ & $\frac{1.5}{2.3}$ & $\frac{0.1}{0.0}$ & $\frac{5.1}{1.7}$ & $\frac{.3}{6.0}$ & 5.6 & 5.0 \\
\hline $\begin{array}{l}\text { Denmank } \\
\text { Finland }\end{array}$ & 1.0 & 0.0 & $\begin{array}{l}.5 \\
0.8\end{array}$ & $\begin{array}{l}3.1 \\
1.8\end{array}$ & $\begin{array}{l}2.6 \\
3.8\end{array}$ & 5.0 & 0.0 & $\begin{array}{l}3.3 \\
2.0\end{array}$ & 0.0 & $\begin{array}{l}.0 \\
4.0\end{array}$ & $\begin{array}{l}.8 \\
1.1\end{array}$ & $\begin{array}{l}3.1 \\
2.1\end{array}$ & $\begin{array}{l}2.0 \\
2.0\end{array}$ & $\begin{array}{l}4.0 \\
4.8\end{array}$ & 4.7 & 0.0 & 5.6 & $\begin{array}{l}.0 \\
6.0\end{array}$ & $\begin{array}{l}5.6 \\
5.9\end{array}$ & $\begin{array}{l}.3 \\
4.9\end{array}$ \\
\hline Mexico & 2.0 & 1.0 & $\begin{array}{l}0.8 \\
0.8\end{array}$ & $\begin{array}{l}1.8 \\
2.6\end{array}$ & $\begin{array}{l}3.8 \\
2.3\end{array}$ & $\begin{array}{l}3.0 \\
3.3\end{array}$ & 0.4 & $\begin{array}{l}2.0 \\
4.7\end{array}$ & 0.0 & $\begin{array}{l}4.0 \\
4.0\end{array}$ & 3.1 & $\begin{array}{l}2.1 \\
1.0\end{array}$ & $\begin{array}{l}2.0 \\
3.0\end{array}$ & $\begin{array}{l}4.8 \\
4.7\end{array}$ & $\begin{array}{l}4.9 \\
1.9\end{array}$ & $\begin{array}{l}.0 \\
1.4\end{array}$ & $\begin{array}{l}3.6 \\
2.1\end{array}$ & $\begin{array}{l}.00 \\
5.0\end{array}$ & $\begin{array}{l}5.9 \\
5.6\end{array}$ & $\begin{array}{l}4.9 \\
4.2\end{array}$ \\
\hline $\begin{array}{l}\text { Mexico } \\
\text { Portugal }\end{array}$ & $\begin{array}{l}2.0 \\
0.0\end{array}$ & 0.0 & $\begin{array}{l}0.8 \\
0.5\end{array}$ & $\begin{array}{l}2.6 \\
0.8\end{array}$ & $\begin{array}{l}2.3 \\
1.1\end{array}$ & $\begin{array}{l}3.3 \\
5.8\end{array}$ & $\begin{array}{l}0.4 \\
0.0\end{array}$ & $\begin{array}{l}4.1 \\
3.5\end{array}$ & 0.7 & $\begin{array}{l}4.0 \\
6.0\end{array}$ & $\begin{array}{l}3.1 \\
1.4\end{array}$ & 2.5 & $\begin{array}{l}3.0 \\
6.0\end{array}$ & $\begin{array}{l}4.1 \\
5.4\end{array}$ & $\begin{array}{l}1.9 \\
1.1\end{array}$ & $\begin{array}{l}1.4 \\
0.0\end{array}$ & $\begin{array}{l}2.1 \\
3.9\end{array}$ & $\begin{array}{l}3.0 \\
6.0\end{array}$ & $\begin{array}{l}3.6 \\
6.0\end{array}$ & $\begin{array}{l}4.2 \\
5.1\end{array}$ \\
\hline $\begin{array}{l}\text { Average - Group 5 } \\
\text { Hungary }\end{array}$ & 0.0 & 0.2 & $\frac{1.1}{1.0}$ & $\frac{1.1}{2.3}$ & $\frac{2.2}{2.9}$ & $\frac{4.6}{2.0}$ & 0.3 & 3.6 & $\frac{0.1}{6.0}$ & $\frac{5.2}{5.0}$ & $\begin{array}{l}1.5 \\
1.5\end{array}$ & $\frac{2.3}{2.2}$ & 3.0 & $\frac{4.1}{5.9}$ & $\frac{3.1}{1.1}$ & 0.3 & $\begin{array}{l}3.9 \\
.3\end{array}$ & $\frac{5.8}{6.0}$ & $\frac{5.8}{6.0}$ & 5.0 \\
\hline Ireland & 0.0 & 0.0 & 2.0 & 2.3 & 3.3 & 3.5 & 1.0 & 3.7 & 6.0 & 2.0 & 0.6 & 3.1 & 5.0 & 5.9 & 0.0 & 0.5 & 6.0 & 6.0 & 4.7 & 5.1 \\
\hline Italy & 0.0 & 0.0 & 1.0 & 0.3 & 3.2 & 5.3 & 0.0 & 5.2 & 6.0 & 6.0 & 1.2 & 2.9 & 5.0 & 4.2 & 2.3 & 0.0 & 2.1 & 6.0 & 5.6 & 5.4 \\
\hline $\begin{array}{l}\text { Italy } \\
\text { New Zealand }\end{array}$ & $\begin{array}{l}0.0 \\
0.0\end{array}$ & $\begin{array}{l}.0 \\
0.0\end{array}$ & $\begin{array}{l}1.0 \\
2.3\end{array}$ & $\begin{array}{l}0.3 \\
1.9\end{array}$ & $\begin{array}{l}3.2 \\
3.3\end{array}$ & $\begin{array}{l}5.3 \\
3.7\end{array}$ & $\begin{array}{l}.0 \\
2.4\end{array}$ & $\begin{array}{l}5.2 \\
2.3\end{array}$ & $\begin{array}{l}6.0 \\
2.0\end{array}$ & $\begin{array}{l}6.0 \\
5.0\end{array}$ & $\begin{array}{l}1.2 \\
0.9\end{array}$ & $\begin{array}{l}2.9 \\
3.9\end{array}$ & $\begin{array}{l}5.0 \\
6.0\end{array}$ & $\begin{array}{l}4.2 \\
4.5\end{array}$ & $\begin{array}{l}2.3 \\
2.6\end{array}$ & $\begin{array}{l}0.0 \\
0.0\end{array}$ & $\begin{array}{l}2.1 \\
4.7\end{array}$ & $\begin{array}{l}6.0 \\
6.0\end{array}$ & $\begin{array}{l}5.6 \\
5.4\end{array}$ & $\begin{array}{l}5.4 \\
5.4\end{array}$ \\
\hline Norway & $\begin{array}{l}0.0 \\
1.0\end{array}$ & 0.0 & $\begin{array}{l}2.3 \\
0.0\end{array}$ & 3.0 & $\begin{array}{l}3.3 \\
3.2\end{array}$ & 5.0 & $\begin{array}{l}.2 .4 \\
1.5\end{array}$ & $\begin{array}{l}.3 \\
3.2\end{array}$ & 6.0 & 6.0 & 0.9 & 4.3 & 6.0 & 4.3 & 3.0 & 0.0 & 5.6 & 6.0 & $\begin{array}{l}.44 \\
5.4\end{array}$ & 5.3 \\
\hline $\begin{array}{l}\text { Noland } \\
\text { Poland }\end{array}$ & 0.0 & 0.0 & 0.8 & $\begin{array}{l}3.0 \\
2.9\end{array}$ & $\begin{array}{l}3.2 \\
3.7\end{array}$ & $\begin{array}{l}5.0 \\
5.2\end{array}$ & $\begin{array}{l}1.5 \\
0.0\end{array}$ & $\begin{array}{l}3.2 \\
1.2\end{array}$ & $\begin{array}{l}0.0 \\
6.0\end{array}$ & 4.0 & 1.5 & 4.0 & 6.0 & 5.4 & 1.8 & 1.3 & 3.9 & 5.9 & 6.0 & 5.3 \\
\hline United Kingdom & 0.0 & 0.0 & 1.0 & 2.0 & 2.9 & 4.3 & 1.6 & 2.3 & 4.0 & 5.0 & 0.7 & 5.0 & 6.0 & 3.7 & 3.0 & 0.0 & 1.3 & 6.0 & 5.9 & 5.6 \\
\hline Average - Group 6 & 0.1 & 0.0 & 1.1 & 2.1 & 3.2 & 4.1 & 1.1 & 3.1 & 5.1 & 4.7 & 1.0 & 3.6 & 5.6 & 4.8 & 2.0 & 0.3 & 4.0 & 6.0 & 5.6 & 5.3 \\
\hline Sample average & 1.3 & 0.7 & 1.5 & 2.8 & 3.1 & 4.2 & 1.1 & 2.9 & 4.4 & 3.1 & 1.2 & 3.0 & 2.9 & 4.5 & 1.9 & 0.9 & 4.6 & 5.9 & 5.8 & 5.1 \\
\hline
\end{tabular}

Note: Country groups shown here are derived from a cluster analysis carried out on the 20 indicators representing health policies and institution
Source: $O E C D$ calculations. 
Figure 18. Groups of countries sharing broadly similar institutions

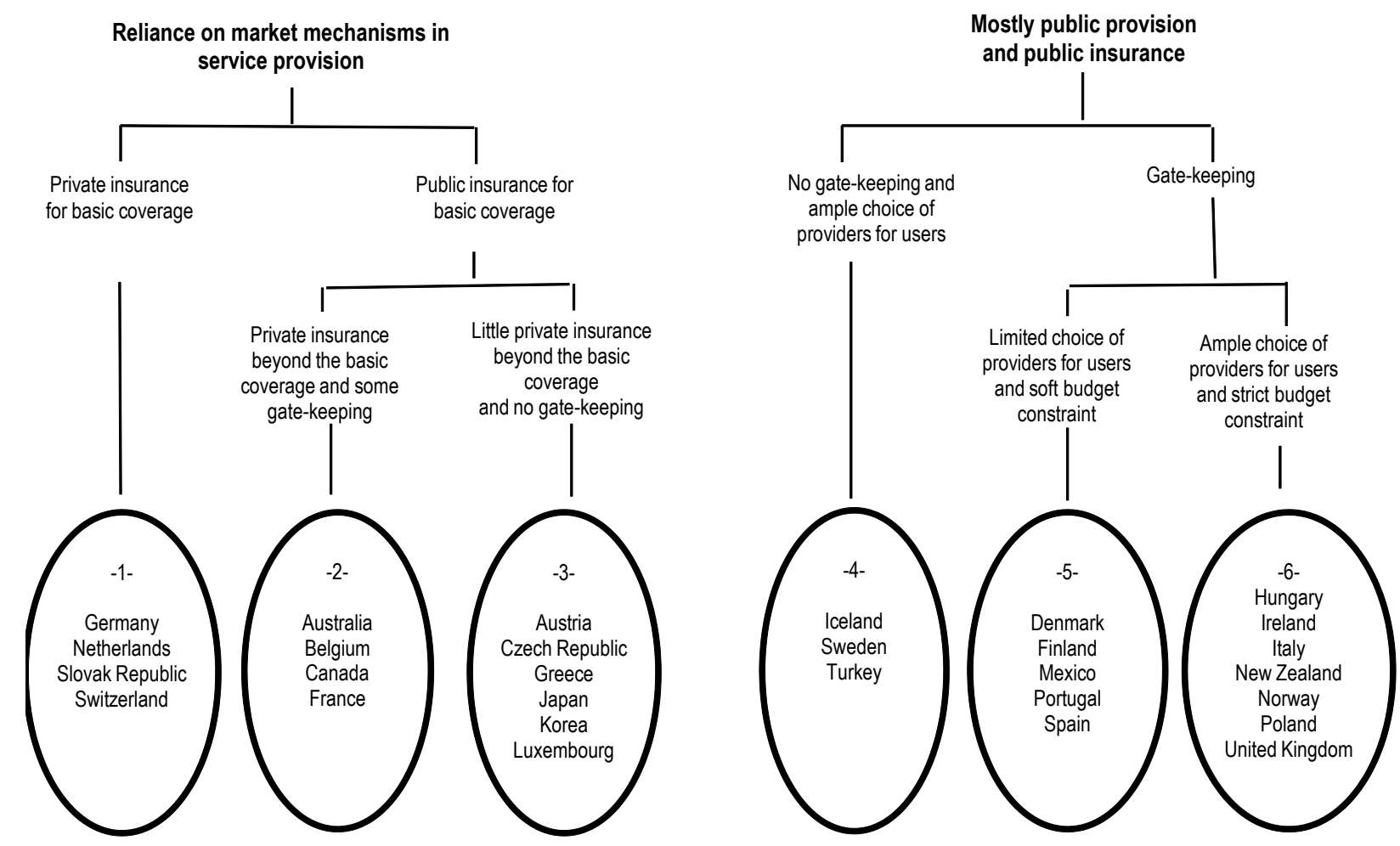




\section{Linking health system performance and policy indicators}

63. Identifying the institutional features conducive to a well performing health care sector is a key objective of this paper. The approach proposed in this section is to compare performance across and within groups of countries sharing similar institutional characteristics and to identify policies which could contribute to differences in performance. This section also suggests how the policy indicators in conjunction with the other indicators contained in the Health Database can be used as a starting point for an in-depth analysis of health care systems.

\section{Efficiency across and within groups of countries sharing similar institutional characteristics}

64. Efficiency levels, as derived from the DEA, vary more within groups of countries sharing similar institutional characteristics than between groups (Figure 19 and Table 9). Thus, there is no indication that one health care system would systematically outperform another. On the contrary, countries performing well can be found in all institutional groups. Countries doing poorly are also present in most groups. The analysis focusing on the efficiency of health care systems can be summarised as follows:

- In the group of the four countries relying extensively on market mechanisms in regulating insurance coverage, efficiency is close to the OECD average but there are large differences between countries. Switzerland is one the best OECD performer; the performance of Germany and the Netherlands is close to the OECD average while the Slovak Republic is performing poorly. These results should be interpreted with caution since, in addition to the uncertainties surrounding efficiency estimates, recent health care system reforms in Germany, the Netherlands and the Slovak Republic might not have had their full impact on efficiency yet.

- In the second group, which is characterised by public basic insurance coverage, heavy reliance on market mechanisms at the provider level and gate-keeping arrangements, average efficiency is slightly above the OECD average.

- The third group, also characterised by an extensive use of market mechanisms at the provider level but less over-the-basic coverage and no gate-keeping, is split into two in terms of efficiency. The two Asian countries - Japan and Korea - are performing very well, whereas the results of the others are close to or below average.

- Efficiency is high in all countries in the group consisting of Iceland, Sweden and Turkey. In this group, users are given ample choice of providers but private supply is very limited and prices are tightly regulated.

- The fifth group, that includes the countries with heavily regulated public systems and with no choice of providers for the users and heavy gate-keeping, is heterogeneous. Mexico, Portugal and Spain are performing fairly well, while the efficiency of the Danish and Finnish systems is low.

- In the last group, consisting of countries with heavily regulated public systems and a stringent budget constraint, performance varies considerably. Italy, Norway, Poland and Portugal are doing quite well. Ireland, New Zealand and the United Kingdom are less efficient though performance scores should be interpreted with particular care in the case of New Zealand and the United Kingdom because recent reforms and increases in spending might require time to fully translate into better health outcomes. Finally, Hungary has been performing poorly. 
Figure 19. DEA efficiency scores across and within country groups

Potential gains in life expectancy (years, DEA)

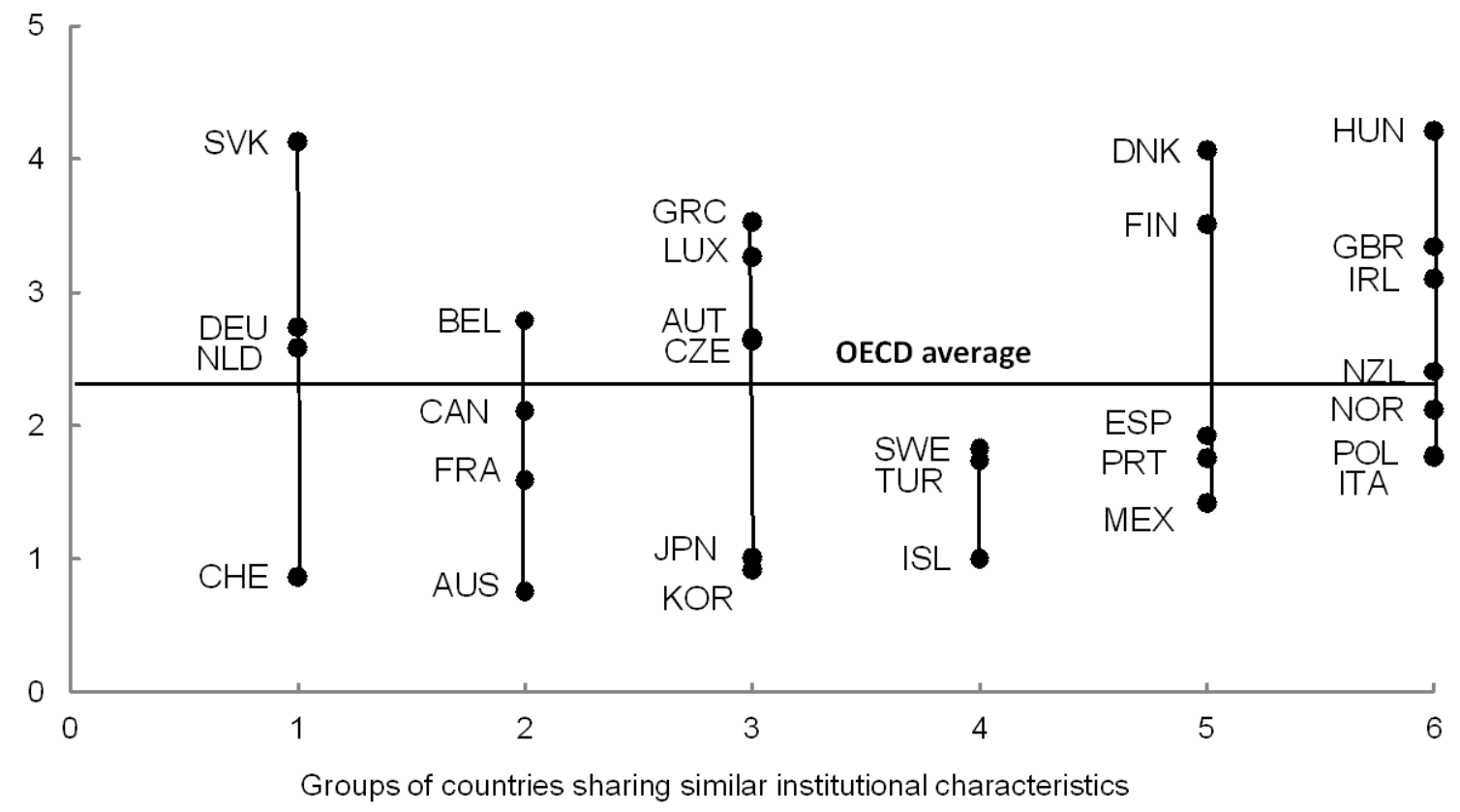

Note: Potential gains in life expectancy are derived from an output oriented DEA with per capita health care spending and a composite indicator of socio-economic environment and lifestyle factors as inputs for 2007.

To facilitate the interpretation, the efficiency scores have been converted into potential gains in life expectancy, i.e. the gains

that a country could achieve for a given level of spending if it were as efficient as the best performing country.

Source: OECD calculations.

Table 9. DEA efficiency scores: means and variances within and across country groups

\begin{tabular}{|c|c|c|c|}
\hline \multicolumn{2}{|c|}{ Country groups } & \multicolumn{2}{|c|}{$\begin{array}{c}\text { Potential gains in life } \\
\text { expectancy, years }\end{array}$} \\
\hline & & \multirow{2}{*}{$\begin{array}{c}\text { Mean } \\
2.6\end{array}$} & \multirow{2}{*}{$\frac{\text { Variance }}{1.34}$} \\
\hline Group 1: & Germany, Netherlands, Slovak Republic, Switzerland & & \\
\hline Group 2: & Australia, Belgium, Canada, France & 1.8 & 0.55 \\
\hline Group 3: & Austria, Czech Republic, Greece, Japan, Korea, Luxembourg & 2.3 & 1.04 \\
\hline Group 4: & Iceland, Sweden, Turkey & 1.5 & 0.14 \\
\hline Group 5: & Denmark, Finland, Mexico, Portugal, Spain & 2.5 & 1.10 \\
\hline Group 6: & Hungary, Ireland, Italy, New Zealand, Norway, Poland, United Kingdom & 2.7 & 0.71 \\
\hline \multicolumn{2}{|l|}{$\begin{array}{l}\text { Total } \\
\text { of which }\end{array}$} & 2.3 & 1.00 \\
\hline \multirow{2}{*}{\multicolumn{2}{|c|}{$\begin{array}{l}\text { Intra-group } \\
\text { Inter-group }\end{array}$}} & - & 0.85 \\
\hline & & - & 0.15 \\
\hline
\end{tabular}

Source: OECD calculations. 
65. Going beyond comparisons of DEA efficiency scores, differences in outcome and spending levels across groups are worth noting:

- There is no clear pattern in life expectancy at birth across country groups and there are significant variations within-group (Figure 20, Panel A).

- Inequalities in health status (Figure 20, Panel B) tend to be lower in countries relying most on private insurance for the basic coverage (group 1), with the exception of the Slovak Republic. This should be interpreted with care, since Germany, the Netherlands and Switzerland have introduced equalisation mechanisms and regulations to mitigate the potential adverse impacts of insurance markets on equity. It should also be recognised that health inequalities are largely driven by socio-economic factors and thus determined outside the health care sector.

- $\quad$ Spending levels per capita (Figure 20, Panel C) tend to be high in countries relying extensively on market mechanisms in managing the basic insurance coverage (group 1) and in countries where private health insurance plays an important role for providing additional coverage (group 2).

- Administrative costs also tend to be higher in those countries relying most on private insurance (groups 1 and 2). At the other extreme, countries relying more on regulations and public providers tend to spend less on administration (Figure 20, Panel D). ${ }^{50}$ Within some groups, however, differences in administrative costs are significant. In particular, the very large administrative costs in Belgium, France, Luxembourg, Mexico and New Zealand may well signal inefficiencies.

\section{Drawing comparisons and identifying weaknesses from a "within-group" analysis}

66. The above analysis suggests that a "big bang" approach may not deliver much in terms of efficiency gains since no "model" is clearly superior in delivering gains in health status for a given level of spending and socio-economic factors. The rest of this section points to areas where achieving greater consistency in policy settings could potentially yield efficiency gains. As the emphasis is put on withingroup comparisons, it is impossible to pursue an econometric approach because of the very small sample size. The analysis relies on the information on performance and policies presented above, as well as other data on health care resources, funding, activity and prices extracted from the OECD Health Database, to spot how each country differs from its peers and whether policy levers exist to improve consistency and thus efficiency (Table 10 and Annex 3). ${ }^{51}$ This wide-ranging set of indicators allows identifying weaknesses and strengths for both high and low performers and should serve as the starting point for an indepth analysis of health care systems. To provide an illustration on how this set can be used, the cases of France and Finland are examined.

50. For those countries financing health care spending mainly via tax revenues, the data may be slightly biased if tax collection costs are not included.

51. The information summarised in the table is shown in more detail in the individual country profiles presented in Annex 3. 
Figure 20. Health outcomes and spending levels across and within country groups

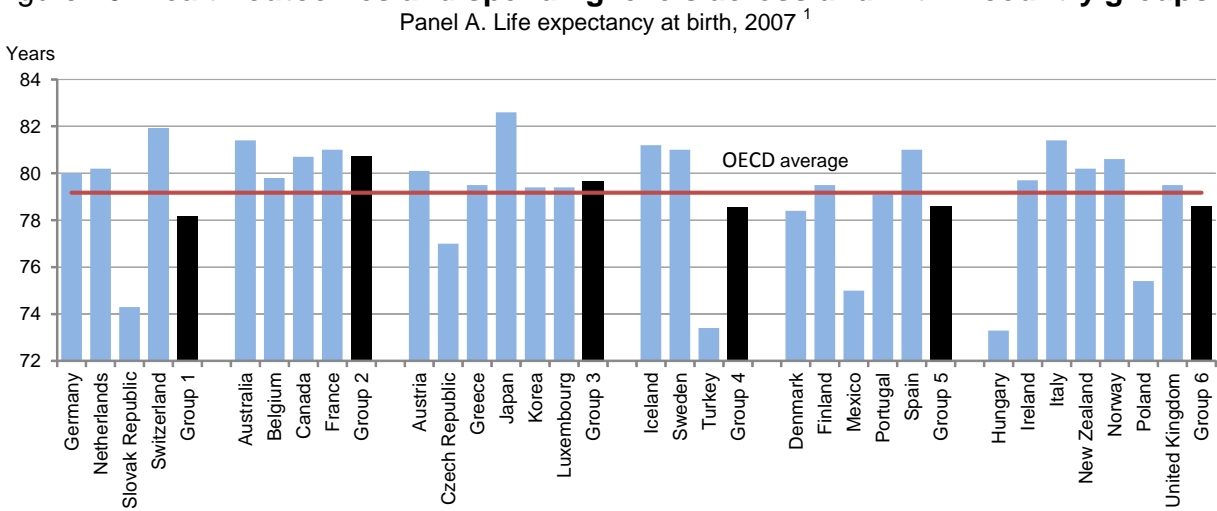

Panel B. Inequalities in health status, $2006^{1,2}$

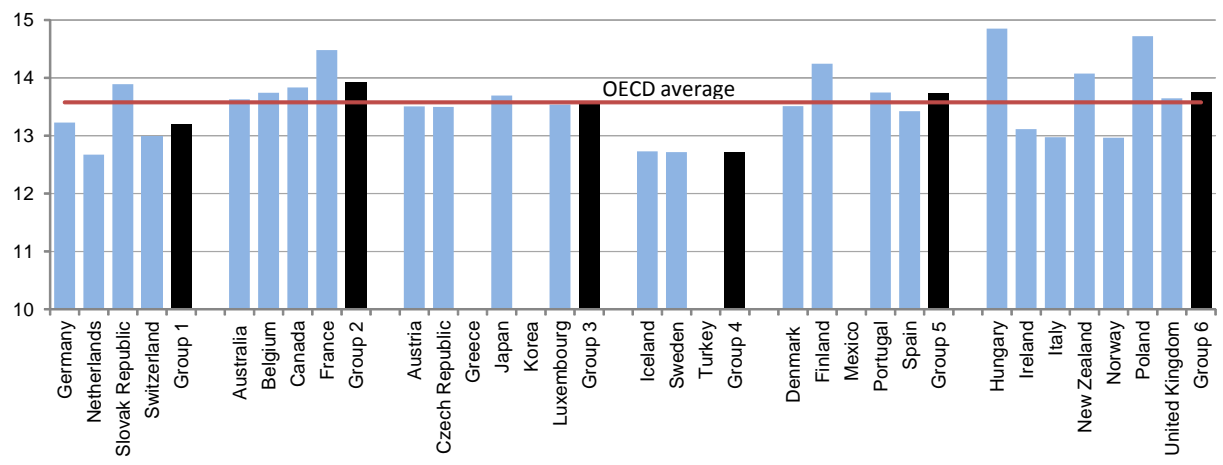

Panel C. Total expenditure on health per capita, $2007^{1}$

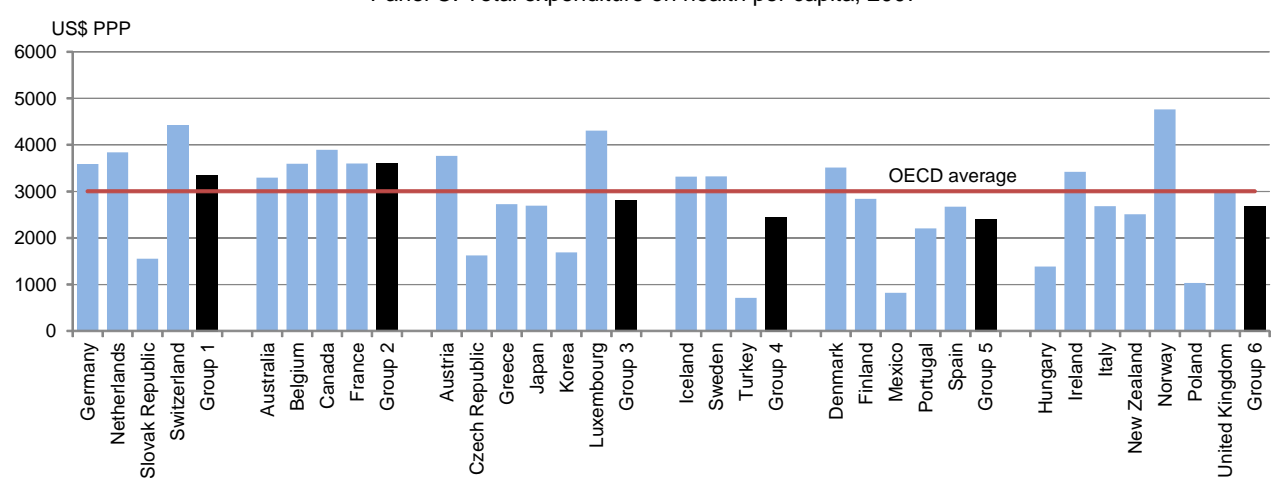

Panel D. Spending on health administration, $2007^{1}$

Per cent total health expenditure

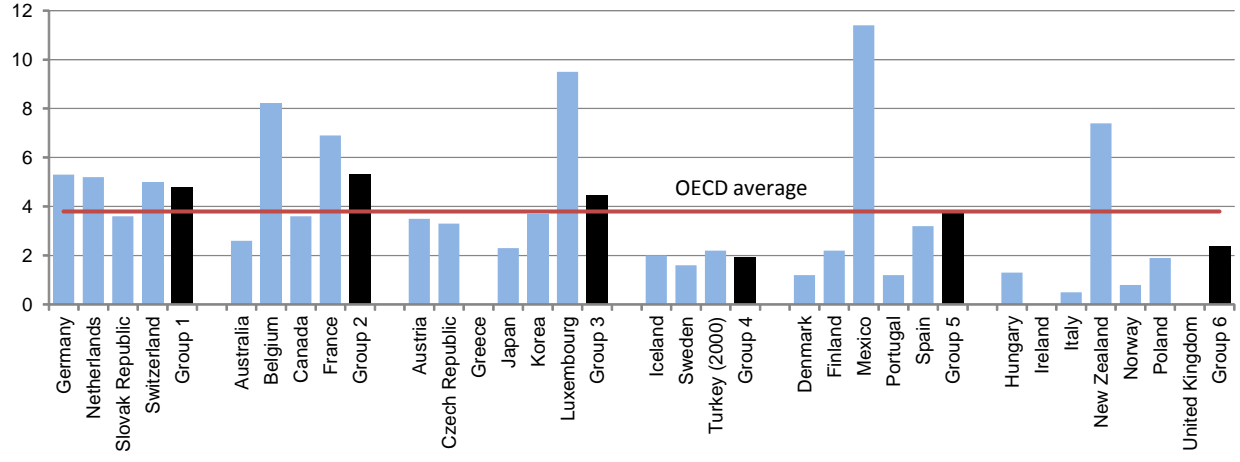

1. Or latest year available.

2. Measured by the standard deviation in mortality ages for population older than 10 .

Source: OECD Health Data 2009; Human Mortality Database (HMD). 
67. France is in the group of countries - together with Australia, Belgium and Canada - where the basic coverage is provided by public insurers and which rely heavily on market mechanisms at the provider level, with a large share of private provision and strong incentives for providers to produce high volumes of services. The average performance of this group of countries is slightly above the OECD average. Within this group, France is characterised by a high efficiency at the system level (as derived by the DEA), a high quality of out-patient and preventive care, and an efficiency level in the acute care sector - as measured by the turnover rate for acute care beds as well as disease-specific ALOSs - that is slightly above the group average (Figure 21, Panel A). Still, the rather long ALOS in the in-patient sector and high share of cataract surgeries performed in the in-patient care sector points to a lack of co-ordination or misallocation of resources between the in- and out-patient care sectors. And inequalities in health status and administrative costs are very high both compared to the group and the OECD average.

68. Looking at the indicators of policies and institutions (Figure 21, Panel B), France stands out for relying heavily on complementary private health insurance as well as for the multiplicity of insurance funds providing the basic coverage. Hence, the role of both specificities in shaping health inequalities and leading to high administrative costs should be assessed. ${ }^{52}$ On the demand side, France offers users more choice among providers while out-of-pocket payments are very low. This may make it difficult to contain excessive demand for health care services though the recently introduced gate-keeping should help in this respect. In the hospital sector, global budgeting has been gradually replaced by an activity-based payment system, which should prompt hospitals to seek efficiency gains and be more responsive to demand. However, the hospital workforce and equipment have remained heavily regulated, which is an issue worth examining, because it may hamper the re-allocation of resources and thus limit the ability of hospitals to exploit efficiency gains.

69. The Finnish health care system, which differs significantly from the French, has been chosen as the second country example. Finland is in the group of countries (with Denmark, Mexico, Portugal and Spain) with a heavily regulated public system, strict gate-keeping and very little choice among providers offered to users. For this group, health care system performance - as measured by the DEA efficiency score and more specific indicators on in-patient efficiency and quality in out-patient care - is slightly below the OECD average. Finland, on the positive side, stands out for its low administrative costs and for a low in-hospital case-fatality rate for stroke, both by OECD standards and compared with the group average. Still, it does not perform as well as the other countries of the group in several respects. The DEA efficiency score is lower and inequalities in health status are higher. Indicators on the quality of out-patient care deliver a mixed picture. In particular, the avoidable hospital admission rate for chronic obstructive pulmonary diseases falls slightly below the OECD and group average. But Finland is also characterised by high rates of avoidable hospital admission rates for asthma and heart failures (Figure 21, Panel C). And patients tend to stay longer in in-patient care for most of the specific diseases included in the set of indicators.

52. The very low level of price signals on users by OECD standards largely reflects the wide coverage by (complementary) PHI. In 2006, PHI covered a large basket of medical goods and services for $88 \%$ of the population. However, out-of-pocket payments may still be high, and thus create difficulties in access, for those not covered by private health insurance (mutuelles). 
Figure 21. Selected indicators for France and Finland

\section{France}

\section{A. Efficiency and quality}

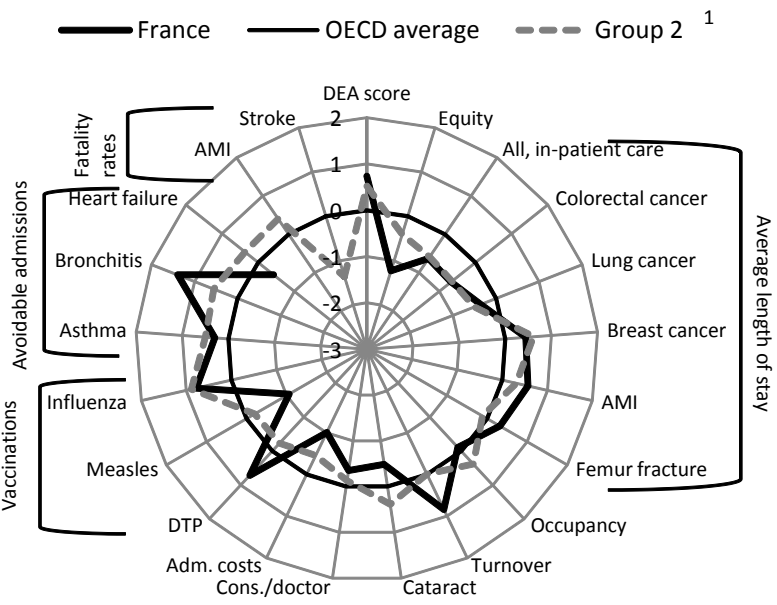

B. Policy and institutions

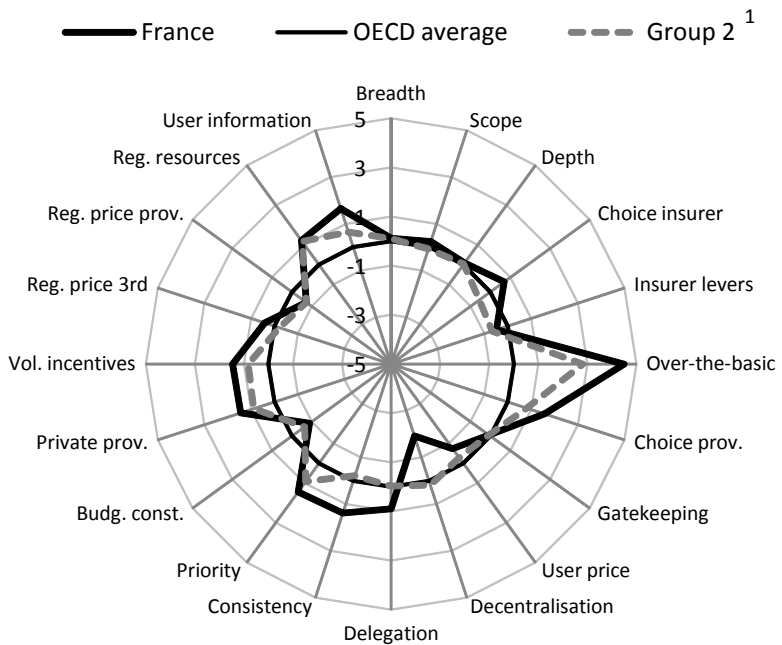

\section{Finland}

C. Efficiency and quality

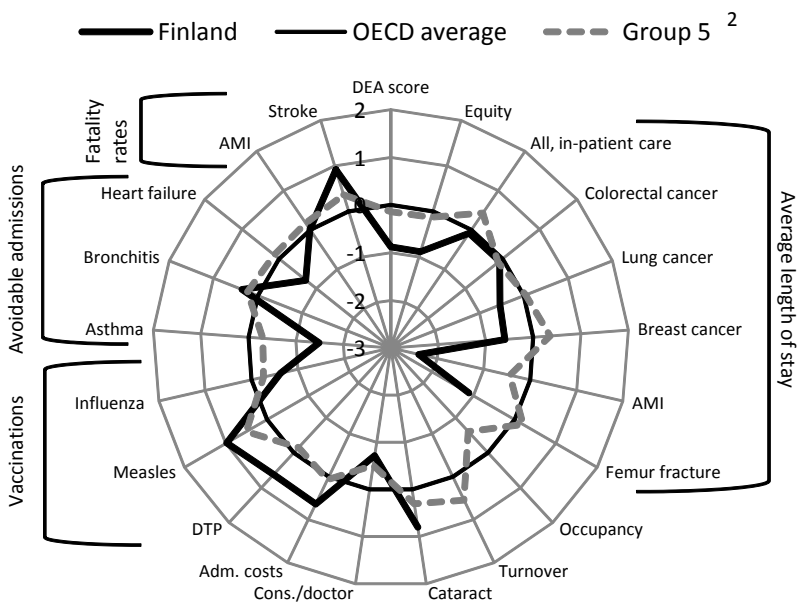

D. Policy and institutions

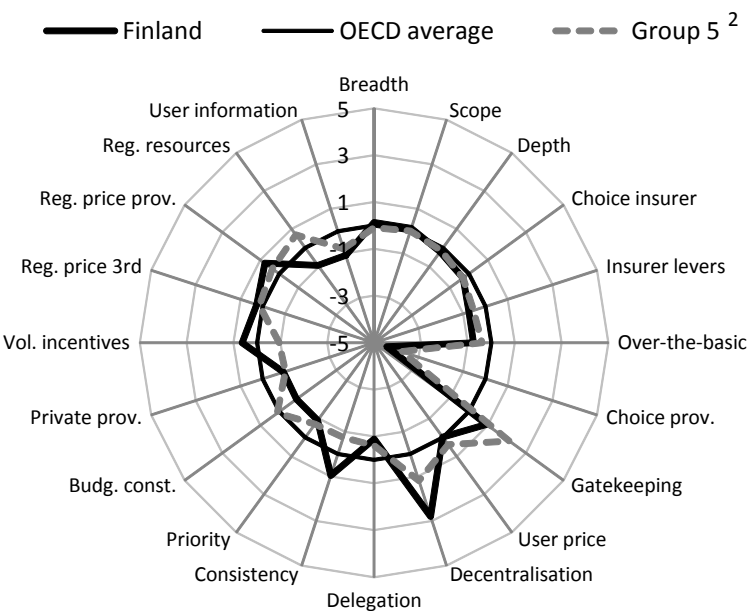

Note: Country groups have been determined by a cluster analysis performed on policy and institutional indicators. In Panels $\mathrm{A}$ and $\mathrm{C}$, data points outside the average circle indicate that the group or the country under scrutiny performs better than the OECD average. In Panels B and D, data points outside the average circle indicate that the level of the variable for the group or the country under scrutiny is higher than the average OECD country. In Panels A and C, data represent the deviation from the OECD average and are expressed in number of standard deviations. In Panels B and $D$, data shown are simple deviations from the OECD average. Each indicator is defined in Annex 3 .

1. Group 2: Australia, Belgium, Canada, France

2. Group 5: Denmark, Finland, Mexico, Portugal, Spain 
70. Finland's health institutions and policies deviate from its peer countries in a number of domains. And some of these specificities could contribute to create a bias in favour of the more expensive in-patient care sector. First, users are offered very limited choice among providers (Figure 21, Panel D). With doctors mostly paid on a salary basis and a very low relative income level for health professionals compared with the OECD and group average, incentives to deliver high quality services in the out-patient care sector are probably low. ${ }^{53}$ Second, gate-keeping arrangements are less well developed than in the other countries in the group. These two specificities may contribute to the large number of hospital discharges per capita. Third, incentives to increase the volume of activity in the hospital sector are higher than in the peer countries; the activity-based compensation system for hospitals (DRG system) creates incentives to respond to demand which may not have been catered for in the out-patient care sector. Fourth, regulations of the hospital workforce and equipment are soft compared to those in the peer countries and do not restrain the size of the hospital sector. ${ }^{54}$ In practice, the in-patient care sector absorbs a very high share of total health care spending (as shown in the full set of indicators for Finland, Annex 3).

71. The above analysis suggests that a "one-size-fits-all" approach to reform is not advisable, at least for some policy instruments: recommendations are clearly system-dependent. In particular, the analysis for Finland and France suggests that increasing consistency in policy settings may entail implementing different, and even seemingly opposite, approaches. The appropriate strength of regulations on hospital workforce and equipment provides an example. Some of the countries where recently reformed hospital payment systems are now mainly based on activity have maintained rather tight regulations of hospital employment and equipment compared to their country peers. These regulations likely reduce flexibility to respond to the new set of incentives and may need to be relaxed (e.g. Belgium, France and Ireland). In contrast, regulation of the hospital workforce and equipment may need to be strengthened in some countries characterised by little use of market mechanisms for service providers, and an above-average supply of hospital facilities (e.g. Finland and Iceland).

72. Some suggestions for policy improvements apply to several countries, independently of their group (Annex 3). Within groups, the most efficient countries tend to be those with the most rigorous priority setting. Hence, better priority setting should be envisaged in those countries where there is no precise definition of the health benefit basket, no effective health technology assessment and clear definition and monitoring of public health objectives. ${ }^{55}$ The consistency of responsibility assignment could be reinforced in many countries to avoid duplication and ensure proper coordination across levels of government involved in health care management. This should be an area for investigation in Austria, Australia, Canada, Denmark, Italy, Mexico, Poland, Sweden, Switzerland and the United Kingdom.

53. The average working time of doctors is also low in Finland (Fujisawa and Lafortune, 2008).

54. The 2003 Economic Survey for Finland noted that the lack of division between purchasing and providing roles was a source of inefficiency, with municipalities acquiring services from hospital districts they were themselves managing. It also recognised that the role of hospitals as large local employers influenced their relationship with municipalities, with hospitals facing a relatively soft budget constraint.

55. Countries have different approaches to priority setting. Some only outline principles to guide prioritisation of health care provision. Others explicitly recommend the services which should be provided, sometimes setting up special bodies to establish priorities and monitor outcomes (e.g. the National Institute for Health and Clinical Excellence [NICE] in the United Kingdom). While there is little evidence that establishing principles has significant effects on health care practice, priority setting bodies with decision making power seem to have been quite successful in some countries (Sabik et al., 2008). In the United Kingdom and the Slovak Republic, rigorous priority setting is not matched by a high level of efficiency. This may reflect fairly recent improvements in priority setting, which were undertaken as a response to unsatisfactory performance. 
Gate-keeping could be introduced or reinforced in some countries to reduce the large number of consultations (e.g. in the Czech Republic, Japan and Korea) or to contain spending in the in-patient sector (e.g. Belgium and Iceland). Price signals on users could be increased where they are low and wide patient choice among providers might induce excessive activity, notably in the Czech Republic and Luxembourg. More information on quality and prices should be provided to users in many countries. In countries where abundant choice of treatment is available, it would enhance competitive pressures. In those where less choice is available, it would allow benchmarking providers and thus help spread best practices.

73. The merits of reforming provider payment schemes should be investigated in many countries, both in the in-patient and out-patient sector. In some of the countries where physicians are compensated mainly through fee-for-services, the level of activity is high in international comparison. Introducing an element of capitation could help reducing the number of consultations and improving the quality of preventive care (Japan, Korea and Germany are examples). In contrast, an activity-based component could be introduced or strengthened in some of the countries relying mainly on salaries (e.g. Greece, Iceland and Sweden) or capitation (Ireland, Poland and the Slovak Republic). Adjusting the relative income level of health practitioners may be warranted - they tend to be low in some eastern European and Nordic countries and are particularly high in the United Kingdom and the United States. Reinforcing the activity-based component and/or adjusting the relative income level of health practitioners would also reduce incentives for informal payments (e.g. Hungary). Likewise, the introduction of a DRG system in countries where it is absent may be an option to improve efficiency in the in-patient sector - notably in Greece, Iceland, Luxembourg, Portugal and Turkey.

74. Inequalities in health status are high in several countries. The reasons for such inequalities vary across countries and result from the health care system or from other socio-economic conditions. In any case, the factors behind health inequalities should be investigated, in order to devise the appropriate policy response. Mexico and Turkey should move further towards achieving universal coverage. It would also be useful to assess whether extensive reliance on over-the-basic coverage (Canada and France) and/or high out-of-pocket payments (Finland, Hungary, Poland and Slovak Republic) create inequities in access and hence inequalities in health status.

\section{Limitations and suggestions for future work}

75. Although conclusions drawn from the analysis above are often largely in line with those from an in-depth assessment contained in recent individual OECD Country Surveys, they should be interpreted with care for a number of reasons:

- Measuring performance remains challenging, and controversial, especially in a context of multiple objectives. A wide uncertainty margin surrounds the DEA efficiency estimates, in particular for those countries with atypical levels of health care inputs. It is thus important to complement the overall efficiency estimates by a broader set of performance indicators efficiency measures based on hospital outputs and quality of care indicators. It should also be recognised that cross-country comparisons allow identifying best practice but may underestimate the full potential efficiency gains as the best performers may not be fully efficient.

- Recent health care reforms may not have yet delivered their full impact on efficiency - the comprehensive health care reform in the Netherlands is a case in point.

- While policy indicators measure the existence of market mechanisms and/or regulations, they hardly reflect their intensity. For instance, the indicator on the stringency of the budget constraint reflects the existence of spending limits embodied in the budget process, but not their levels and whether limits are complied with. 
- The set of institutional and policy indicators does not currently allow a solid analysis of at least three domains often identified as priorities in the OECD Economic Surveys and Reviews of Health Systems, namely the pharmaceutical sector (e.g. incentives for using generics), co-ordination of care (e.g. across in-patient, acute and long-term care settings) and sick leaves. In addition, the existing indicators may need to be refined in a number of areas, including the nature of health insurance markets (e.g. individual versus collective contracts) and the design of out-ofpocket payments.

These limitations clearly call for further work in regularly updating and developing the set of institutional and policy indicators and for complementing the work on indicators by an in-depth assessment of individual country health care systems. 


\begin{tabular}{|c|c|c|c|c|c|c|}
\hline & $\begin{array}{l}\text { Efficiency and } \\
\text { quality }\end{array}$ & $\begin{array}{l}\text { Prices and physical } \\
\text { resources }\end{array}$ & $\begin{array}{l}\text { Activity and } \\
\text { consumption }\end{array}$ & $\begin{array}{l}\text { Financing and } \\
\text { spending mix }\end{array}$ & Policies and institutions & $\begin{array}{l}\text { Weaknesses and policy inconsistencies } \\
\text { emerging from the set of indicators }\end{array}$ \\
\hline GROUP 1: & \multicolumn{6}{|c|}{ Extensive reliance on market mechanisms in regulating both basic and "over-the-basic" insurance coverage and abundant private provision of health care. } \\
\hline \multirow[t]{4}{*}{ Germany } & $\begin{array}{l}\text { About group- } \\
\text { average DEA score }\end{array}$ & & & $\begin{array}{l}\text { Large publicly funded } \\
\text { share and lower out-of- } \\
\text { pocket share }\end{array}$ & $\begin{array}{l}\text { More competitive pressures in } \\
\text { the insurance market }\end{array}$ & \\
\hline & $\begin{array}{l}\text { Mixed scores on } \\
\text { output/hospital } \\
\text { efficiency }\end{array}$ & $\begin{array}{l}\text { More acute care } \\
\text { beds per capita }\end{array}$ & $\begin{array}{l}\text { More hospital } \\
\text { discharges per } \\
\text { capita }\end{array}$ & & $\begin{array}{l}\text { More choice among providers } \\
\text { and less price signals on users }\end{array}$ & $\begin{array}{l}\text { Assess the best balance between extensive user } \\
\text { choice and low out-of-pocket payments in case } \\
\text { clear signs of excessive demand for health care } \\
\text { services emerge }\end{array}$ \\
\hline & $\begin{array}{l}\text { Mixed scores on the } \\
\text { quality of out-patient } \\
\text { and preventive care }\end{array}$ & & & & $\begin{array}{l}\text { More provider incentives and } \\
\text { more regulation on resources }\end{array}$ & $\begin{array}{l}\text { Consider whether reforming provider payment } \\
\text { systems could help avoiding excessive activity, } \\
\text { e.g. by combining existing fee-for-services for } \\
\text { physicians with a capitation and/or salary element }\end{array}$ \\
\hline & $\begin{array}{l}\text { Administrative costs } \\
\text { are broadly in line } \\
\text { with the group } \\
\text { average }\end{array}$ & $\begin{array}{l}\text { High relative income } \\
\text { level of GPs and } \\
\text { nurses }\end{array}$ & & & & \\
\hline \multirow[t]{4}{*}{ Netherlands } & $\begin{array}{l}\text { About group- } \\
\text { average DEA score } \\
\text { but lower inequalities } \\
\text { in health status }\end{array}$ & & & $\begin{array}{l}\text { More reliance on social } \\
\text { insurance financing and } \\
\text { less on out-of-pocket } \\
\text { payments }\end{array}$ & $\begin{array}{l}\text { Market mechanisms in } \\
\text { delivering basic insurance } \\
\text { coverage play an important } \\
\text { role but the insurance market } \\
\text { remains more concentrated } \\
\text { than in the peer countries }\end{array}$ & $\begin{array}{l}\text { Ensure that competitive pressures in the insurance } \\
\text { market are strong enough }\end{array}$ \\
\hline & $\begin{array}{l}\text { Mixed scores on } \\
\text { output/acute hospital } \\
\text { care efficiency }\end{array}$ & $\begin{array}{l}\text { Less high-tech } \\
\text { equipment and acute } \\
\text { care beds per capita }\end{array}$ & $\begin{array}{l}\text { Low number of } \\
\text { hospital } \\
\text { discharges and } \\
\text { consumption of } \\
\text { pharmaceuticals } \\
\text { per capita }\end{array}$ & & $\begin{array}{l}\text { Less volume incentives, in } \\
\text { particular at the hospital level }\end{array}$ & $\begin{array}{l}\text { Examine the relatively low activity levels of } \\
\text { hospitals and whether reforming hospital payment } \\
\text { systems could improve hospital incentives to better } \\
\text { respond to needs }\end{array}$ \\
\hline & $\begin{array}{l}\text { High quality of out- } \\
\text { patient and } \\
\text { preventive care }\end{array}$ & $\begin{array}{l}\text { More doctors and } \\
\text { medical students }\end{array}$ & & Lower out-patient share & $\begin{array}{l}\text { Less choice among providers } \\
\text { and more gate-keeping }\end{array}$ & \\
\hline & $\begin{array}{l}\text { Administrative costs } \\
\text { are broadly in line } \\
\text { with the group } \\
\text { average }\end{array}$ & $\begin{array}{l}\text { Higher relative } \\
\text { income level of } \\
\text { specialists and GPs }\end{array}$ & & & $\begin{array}{l}\text { Less decentralisation, } \\
\text { consistent responsibility } \\
\text { assignment }\end{array}$ & \\
\hline
\end{tabular}


ECO/WKP(2010)25

\begin{tabular}{|c|c|c|c|c|c|c|}
\hline & $\begin{array}{l}\text { Efficiency and } \\
\text { quality }\end{array}$ & $\begin{array}{l}\text { Prices and physical } \\
\text { resources }\end{array}$ & $\begin{array}{l}\text { Activity and } \\
\text { consumption }\end{array}$ & $\begin{array}{l}\text { Financing and } \\
\text { spending mix }\end{array}$ & Policies and institutions & $\begin{array}{l}\text { Weaknesses and policy inconsistencies } \\
\text { emerging from the set of indicators }\end{array}$ \\
\hline \multirow[t]{4}{*}{$\begin{array}{l}\text { Slovak } \\
\text { Republic }\end{array}$} & $\begin{array}{l}\text { Low DEA score and } \\
\text { high amenable } \\
\text { mortality rate }\end{array}$ & & & $\begin{array}{l}\text { Lower public spending } \\
\text { share and higher out-of- } \\
\text { pocket payments }\end{array}$ & $\begin{array}{l}\text { No market for the "over-the } \\
\text { basic" coverage }\end{array}$ & $\begin{array}{l}\text { The Slovak health care system seems in transition } \\
\text { with private provision and market instruments } \\
\text { (payment per case for hospitals and user fees) } \\
\text { introduced or increased recently }\end{array}$ \\
\hline & $\begin{array}{l}\text { Mixed scores on } \\
\text { output/hospital } \\
\text { efficiency }\end{array}$ & $\begin{array}{l}\text { Less nurses and } \\
\text { high-tech equipment, } \\
\text { but more acute care } \\
\text { beds }\end{array}$ & $\begin{array}{l}\text { More hospital } \\
\text { discharges per } \\
\text { capita }\end{array}$ & Low in-patient share & $\begin{array}{l}\text { Less choice of providers. More } \\
\text { gate-keeping and price signals } \\
\text { on users. }\end{array}$ & \\
\hline & $\begin{array}{l}\text { Mixed signals on } \\
\text { quality of out-patient } \\
\text { preventive care }\end{array}$ & $\begin{array}{l}\text { Very low relative } \\
\text { income level of GPs } \\
\text { and nurses }\end{array}$ & $\begin{array}{l}\text { More doctor } \\
\text { consultations per } \\
\text { capita }\end{array}$ & Very high drug share & $\begin{array}{l}\text { Less volume incentives } \\
\text { (physicians are paid on } \\
\text { capitation and/or salary) and } \\
\text { less regulation on resources }\end{array}$ & $\begin{array}{l}\text { Reconsidering the payment system and, possibly, } \\
\text { the level of income of health care practitioners } \\
\text { could reinforce providers' incentives to respond to } \\
\text { the need for higher quality health care services }\end{array}$ \\
\hline & $\begin{array}{l}\text { About average } \\
\text { administrative costs }\end{array}$ & & & & & \\
\hline \multirow[t]{4}{*}{ Switzerland } & $\begin{array}{l}\text { High DEA score and } \\
\text { low inequalities in } \\
\text { health status }\end{array}$ & $\begin{array}{l}\text { High health care } \\
\text { spending per capita } \\
\text { and as a share of } \\
\text { GDP }\end{array}$ & & $\begin{array}{l}\text { Large share of out-of- } \\
\text { pocket payments }\end{array}$ & $\begin{array}{l}\text { Less levers for competition for } \\
\text { insurers offering basic } \\
\text { insurance cover as they are } \\
\text { not allowed to contract } \\
\text { selectively with providers }\end{array}$ & $\begin{array}{l}\text { Assess the potential merits of selective contracting } \\
\text { clauses }\end{array}$ \\
\hline & $\begin{array}{l}\text { Mixed scores on } \\
\text { output/hospital } \\
\text { efficiency }\end{array}$ & $\begin{array}{l}\text { More high-tech } \\
\text { equipment and less } \\
\text { acute care beds }\end{array}$ & & Higher in-patient share & $\begin{array}{l}\text { Less information for users on } \\
\text { the quality and prices of } \\
\text { services }\end{array}$ & $\begin{array}{l}\text { More information on the quality and prices of } \\
\text { services could raise competition and contain health } \\
\text { care prices }\end{array}$ \\
\hline & $\begin{array}{l}\text { High quality of out- } \\
\text { patient and } \\
\text { preventive care }\end{array}$ & $\begin{array}{l}\text { More doctors and } \\
\text { nurses per capita }\end{array}$ & $\begin{array}{l}\text { Less doctor } \\
\text { consultations per } \\
\text { capita }\end{array}$ & Low drug share & $\begin{array}{l}\text { Less gate-keeping and more } \\
\text { out-of-pocket payments }\end{array}$ & $\begin{array}{l}\text { The balance between gate-keeping and out-of- } \\
\text { pocket payments, as mechanisms to avoid } \\
\text { excessive demand, could be examined }\end{array}$ \\
\hline & $\begin{array}{l}\text { Administrative costs } \\
\text { are broadly in line } \\
\text { with the group } \\
\text { average }\end{array}$ & $\begin{array}{l}\text { High health care } \\
\text { prices }\end{array}$ & & & $\begin{array}{l}\text { More decentralisation but less } \\
\text { consistency in responsibility } \\
\text { assignment across levels of } \\
\text { governments }\end{array}$ & $\begin{array}{l}\text { Improved consistency in the allocation of } \\
\text { responsibilities across levels of government could } \\
\text { help exploiting efficiency gains }\end{array}$ \\
\hline
\end{tabular}


ECO/WKP(2010)25

\begin{tabular}{|c|c|c|c|c|c|c|}
\hline & $\begin{array}{l}\text { Efficiency and } \\
\text { quality }\end{array}$ & $\begin{array}{l}\text { Prices and physical } \\
\text { resources }\end{array}$ & $\begin{array}{l}\text { Activity and } \\
\text { consumption }\end{array}$ & $\begin{array}{l}\text { Financing and } \\
\text { spending mix }\end{array}$ & Policies and institutions & $\begin{array}{l}\text { Weaknesses and policy inconsistencies } \\
\text { emerging from the set of indicators }\end{array}$ \\
\hline GROUP 2: & \multicolumn{6}{|c|}{$\begin{array}{l}\text { Public basic insurance coverage combined with private insurance beyond the basic coverage. Heavy reliance on market mechanisms at the provider level, with wide patient choice among } \\
\text { providers and fairly large incentives to produce high volumes of services contained by gate-keeping arrangements. }\end{array}$} \\
\hline \multirow[t]{4}{*}{ Australia } & High DEA score & $\begin{array}{l}\text { Less doctors per } \\
\text { capita }\end{array}$ & & Lower public share & & \\
\hline & $\begin{array}{l}\text { Rather high output } \\
\text { efficiency in the } \\
\text { acute care sector but } \\
\text { long stays in the in- } \\
\text { patient care sector }\end{array}$ & & $\begin{array}{l}\text { Less hospital } \\
\text { discharges }\end{array}$ & & $\begin{array}{l}\text { Less volume incentives, in } \\
\text { particular in the in-patient care } \\
\text { sector }\end{array}$ & $\begin{array}{l}\text { Examine the reasons behind the long stays in the } \\
\text { in-patient (non-acute) care sector }\end{array}$ \\
\hline & $\begin{array}{l}\text { Data missing on } \\
\text { quality of care }\end{array}$ & $\begin{array}{l}\text { Lower income level } \\
\text { for GPs }\end{array}$ & & $\begin{array}{l}\text { Higher out-patient } \\
\text { share; lower drug share }\end{array}$ & Less gate-keeping & $\begin{array}{l}\text { Improve availability of internationally comparable } \\
\text { data on quality of care }\end{array}$ \\
\hline & $\begin{array}{l}\text { Low administrative } \\
\text { costs }\end{array}$ & & & & $\begin{array}{l}\text { More decentralisation, less } \\
\text { consistency, more priority setting, } \\
\text { less regulation of resources }\end{array}$ & $\begin{array}{l}\text { Improved consistency in the allocation of } \\
\text { responsibilities across levels of government could } \\
\text { generate efficiency gains }\end{array}$ \\
\hline \multirow[t]{4}{*}{ Belgium } & $\begin{array}{l}\text { Below group- } \\
\text { average DEA score }\end{array}$ & & & $\begin{array}{l}\text { Higher social security } \\
\text { share }\end{array}$ & & \\
\hline & $\begin{array}{l}\text { Lower scores on } \\
\text { output/acute care } \\
\text { efficiency }\end{array}$ & $\begin{array}{l}\text { More doctors, } \\
\text { nurses, high-tech } \\
\text { equipment and acute } \\
\text { care beds per capita }\end{array}$ & & $\begin{array}{l}\text { Higher in-patient care } \\
\text { share }\end{array}$ & $\begin{array}{l}\text { Less gate-keeping but more user } \\
\text { information on quality and prices } \\
\text { of services }\end{array}$ & $\begin{array}{l}\text { Assess the merits of stricter gate-keeping } \\
\text { arrangements in containing the number of doctor } \\
\text { consultations per capita }\end{array}$ \\
\hline & $\begin{array}{l}\text { Below group- } \\
\text { average quality of } \\
\text { out-patient care (but } \\
\text { still above OECD } \\
\text { average) }\end{array}$ & $\begin{array}{l}\text { Higher income level } \\
\text { of specialists and } \\
\text { salaried nurses }\end{array}$ & $\begin{array}{l}\text { More doctor } \\
\text { consultations per } \\
\text { capita }\end{array}$ & & $\begin{array}{l}\text { More provider incentives and } \\
\text { private provision. More regulation } \\
\text { of prices paid by third-party } \\
\text { payers, and of physician } \\
\text { workforce, hospital equipment } \\
\text { and compensation levels }\end{array}$ & $\begin{array}{l}\text { Reconsider government controls on labour, } \\
\text { equipment and compensation levels, which may } \\
\text { undermine hospital performance }\end{array}$ \\
\hline & $\begin{array}{l}\text { Very high } \\
\text { administrative costs }\end{array}$ & & & & $\begin{array}{l}\text { Less decentralisation and less } \\
\text { priority setting }\end{array}$ & $\begin{array}{l}\text { Explore options to reduce administrative costs. } \\
\text { Improved priority setting could help delivering } \\
\text { efficiency gains }\end{array}$ \\
\hline
\end{tabular}


ECO/WKP(2010)25

\begin{tabular}{|c|c|c|c|c|c|c|}
\hline & $\begin{array}{l}\text { Efficiency and } \\
\text { quality }\end{array}$ & $\begin{array}{l}\text { Prices and physical } \\
\text { resources }\end{array}$ & $\begin{array}{l}\text { Activity and } \\
\text { consumption }\end{array}$ & $\begin{array}{l}\text { Financing and } \\
\text { spending mix }\end{array}$ & Policies and institutions & $\begin{array}{l}\text { Weaknesses and policy inconsistencies } \\
\text { emerging from the set of indicators }\end{array}$ \\
\hline \multirow[t]{4}{*}{ Canada } & $\begin{array}{l}\text { High DEA score but } \\
\text { slightly higher } \\
\text { inequalities in health } \\
\text { status. Low rate of } \\
\text { amenable mortality }\end{array}$ & & & Higher PHI share & $\begin{array}{l}\text { Lower scope of basic insurance } \\
\text { coverage and heavy reliance on } \\
\text { (supplementary) PHls }\end{array}$ & $\begin{array}{l}\text { Assess the main causes of the inequalities in } \\
\text { health status and, in particular, the role of the } \\
\text { insurance system and of the scope of the basic } \\
\text { insurance package }\end{array}$ \\
\hline & $\begin{array}{l}\text { Mixed signals on } \\
\text { output/hospital } \\
\text { efficiency }\end{array}$ & $\begin{array}{l}\text { Less high-tech } \\
\text { equipment and acute } \\
\text { care beds }\end{array}$ & $\begin{array}{l}\text { Less hospital } \\
\text { discharges per } \\
\text { capita }\end{array}$ & Lower in-patient share & $\begin{array}{l}\text { Less choice among providers and } \\
\text { more gate-keeping }\end{array}$ & \\
\hline & $\begin{array}{l}\text { High quality of out- } \\
\text { patient and preventive } \\
\text { care }\end{array}$ & $\begin{array}{l}\text { Less doctors and } \\
\text { medical students }\end{array}$ & $\begin{array}{l}\text { Less } \\
\text { consultations of } \\
\text { doctors per } \\
\text { capita }\end{array}$ & & $\begin{array}{l}\text { Less private provision and volume } \\
\text { incentives. More regulation on } \\
\text { provider prices and on workforce } \\
\text { and equipment }\end{array}$ & $\begin{array}{l}\text { Regulations on hospital employment and } \\
\text { equipment may need to be softened if hospitals are } \\
\text { increasingly paid on the basis of their activity }\end{array}$ \\
\hline & $\begin{array}{l}\text { Lower administrative } \\
\text { costs }\end{array}$ & $\begin{array}{l}\text { Higher relative } \\
\text { income level of GPs }\end{array}$ & & & $\begin{array}{l}\text { Less regulation on prices paid by } \\
\text { third-party payers. Higher } \\
\text { decentralisation but less } \\
\text { consistency in responsibility } \\
\text { assignment. Less priority setting }\end{array}$ & $\begin{array}{l}\text { Higher consistency in the allocation of } \\
\text { responsibilities across levels of government could } \\
\text { deliver efficiency gains }\end{array}$ \\
\hline \multirow[t]{4}{*}{ France } & $\begin{array}{l}\text { High DEA score and } \\
\text { OECD best performer } \\
\text { on amenable mortality } \\
\text { but high inequities in } \\
\text { health status }\end{array}$ & $\begin{array}{l}\text { Higher health care } \\
\text { spending as a share } \\
\text { of GDP }\end{array}$ & & $\begin{array}{l}\text { Higher public, social } \\
\text { security and PHI } \\
\text { shares; less out-of- } \\
\text { pocket payments }\end{array}$ & $\begin{array}{l}\text { More reliance on market forces in } \\
\text { the insurance sector }\end{array}$ & $\begin{array}{l}\text { Explore the main causes for high inequities in } \\
\text { health status, and in particular the role of over-the- } \\
\text { basic coverage (assurances complémentaires) }\end{array}$ \\
\hline & $\begin{array}{l}\text { Mixed scores on } \\
\text { output/hospital } \\
\text { efficiency }\end{array}$ & $\begin{array}{l}\text { Less nurses and } \\
\text { high-tech equipment }\end{array}$ & $\begin{array}{l}\text { More hospital } \\
\text { discharges }\end{array}$ & Higher in-patient share & $\begin{array}{l}\text { More choice among providers, } \\
\text { less price signals }\end{array}$ & \\
\hline & $\begin{array}{l}\text { Rather high quality of } \\
\text { (out-patient) care }\end{array}$ & $\begin{array}{l}\text { Less medical } \\
\text { students }\end{array}$ & & Lower out-patient share & $\begin{array}{l}\text { More private provision and } \\
\text { incentives to increase volumes. } \\
\text { More regulation of workforce and } \\
\text { equipment, in particular in the } \\
\text { hospital sector, and of prices paid } \\
\text { by third-party payers. }\end{array}$ & $\begin{array}{l}\text { Reconsider government controls on labour and } \\
\text { equipment in the in-patient care sector (the reform } \\
\text { of the hospital payment system may require more } \\
\text { flexibility on labour and equipment for hospitals to } \\
\text { adjust to the new set of incentives) }\end{array}$ \\
\hline & $\begin{array}{l}\text { Very high } \\
\text { administrative costs }\end{array}$ & & & & Less decentralisation & $\begin{array}{l}\text { Explore options to reduce administrative costs, } \\
\text { including the consolidation of social security funds }\end{array}$ \\
\hline
\end{tabular}




\begin{tabular}{|c|c|c|c|c|c|c|}
\hline & $\begin{array}{l}\text { Efficiency and } \\
\text { quality }\end{array}$ & $\begin{array}{l}\text { Prices and physical } \\
\text { resources }\end{array}$ & $\begin{array}{l}\text { Activity and } \\
\text { consumption }\end{array}$ & $\begin{array}{l}\text { Financing and } \\
\text { spending mix }\end{array}$ & Policies and institutions & $\begin{array}{l}\text { Weaknesses and policy inconsistencies emerging } \\
\text { from the set of indicators }\end{array}$ \\
\hline GROUP 3: & \multicolumn{6}{|c|}{$\begin{array}{l}\text { Public basic insurance coverage with little private insurance beyond the basic coverage. Extensive private provision of care, with wide patient choice among providers and fairly large } \\
\text { incentives to produce high volumes of services. No gate-keeping and soft budget constraint. Limited information on quality and prices to stimulate competition. }\end{array}$} \\
\hline \multirow[t]{4}{*}{ Austria } & $\begin{array}{l}\text { About average DEA } \\
\text { score; low rates of } \\
\text { amenable mortality }\end{array}$ & $\begin{array}{l}\text { Higher health care } \\
\text { spending per capita } \\
\text { and as a share of } \\
\text { GDP }\end{array}$ & $\begin{array}{l}\text { More hospital } \\
\text { discharges per } \\
\text { capita }\end{array}$ & Lower out-of-pocket share & $\begin{array}{l}\text { More generous insurance } \\
\text { coverage }\end{array}$ & $\begin{array}{l}\text { Consider whether rebalancing resources from the in- } \\
\text { patient to the out-patient care sector could contribute } \\
\text { to increasing health spending efficiency. Introducing } \\
\text { gate-keeping arrangements and/or restricting the use } \\
\text { of retrospective payment of costs for hospitals could } \\
\text { be options to avoid excessive in-patient activity. } \\
\text { Reforms should also aim at increasing the quality of } \\
\text { out-patient/preventive care }\end{array}$ \\
\hline & $\begin{array}{l}\text { Rather high hospital } \\
\text { (output) efficiency }\end{array}$ & $\begin{array}{l}\text { More acute care } \\
\text { beds per capita than } \\
\text { the OECD average }\end{array}$ & & Higher in-patient share & Less choice of provider & \\
\hline & $\begin{array}{l}\text { Below average } \\
\text { scores on the quality } \\
\text { of out-patient } \\
\text { preventive care }\end{array}$ & $\begin{array}{l}\text { More doctors and } \\
\text { students per capita. } \\
\text { Higher relative } \\
\text { income level of } \\
\text { specialists and GPs }\end{array}$ & & Lower drug share & $\begin{array}{l}\text { Less private provision and } \\
\text { volume incentives and more } \\
\text { regulation of resources }\end{array}$ & \\
\hline & & & & & $\begin{array}{l}\text { More decentralisation and less } \\
\text { consistency. Less priority } \\
\text { setting and little constraint put } \\
\text { on health care spending via } \\
\text { the budget process }\end{array}$ & $\begin{array}{l}\text { Enhanced priority setting, more choice among } \\
\text { providers and information on the quality and prices of } \\
\text { services could help. Improve consistency in the } \\
\text { allocation of responsibilities across levels of } \\
\text { government as decision-making and financing are still } \\
\text { often divided among different levels of government }\end{array}$ \\
\hline \multirow[t]{4}{*}{$\begin{array}{l}\text { Czech } \\
\text { Republic }\end{array}$} & $\begin{array}{l}\text { Below average DEA } \\
\text { score and higher } \\
\text { rate of amenable } \\
\text { mortality }\end{array}$ & $\begin{array}{l}\text { Lower health care } \\
\text { spending per capita } \\
\text { and as a share of } \\
\text { GDP }\end{array}$ & $\begin{array}{l}\text { More hospital } \\
\text { discharges per } \\
\text { capita }\end{array}$ & $\begin{array}{l}\text { Higher publicly funded } \\
\text { share. Lower out-of-pocket } \\
\text { payments }\end{array}$ & $\begin{array}{l}\text { More market orientation of the } \\
\text { basic insurance segment }\end{array}$ & $\begin{array}{l}\text { The Czech health care system seems in transition } \\
\text { with private provision and market instruments (global } \\
\text { budget plus payment per case and per procedure for } \\
\text { hospitals and user fees) introduced or increased } \\
\text { recently }\end{array}$ \\
\hline & $\begin{array}{l}\text { Rather low acute } \\
\text { care (output) } \\
\text { efficiency }\end{array}$ & $\begin{array}{l}\text { More acute care } \\
\text { beds than the OECD } \\
\text { average and less } \\
\text { high-tech equipment }\end{array}$ & & & $\begin{array}{l}\text { More choice of providers, no } \\
\text { gate-keeping and low price } \\
\text { signals on users }\end{array}$ & $\begin{array}{l}\text { Increasing co-payments, which are currently relatively } \\
\text { low, and/or introducing some gate-keeping could be } \\
\text { envisaged. This would help containing the rather high } \\
\text { level of health activity and consumption and balance } \\
\text { the high degree of provider choice given to users }\end{array}$ \\
\hline & $\begin{array}{l}\text { Few data on the } \\
\text { quality of out-patient } \\
\text { and preventive care }\end{array}$ & $\begin{array}{l}\text { More doctors per } \\
\text { capita. Very low } \\
\text { relative income level } \\
\text { of health } \\
\text { practitioners }\end{array}$ & $\begin{array}{l}\text { More doctor } \\
\text { consultations per } \\
\text { capita }\end{array}$ & $\begin{array}{l}\text { Lower out-patient share. } \\
\text { Higher drug share }\end{array}$ & $\begin{array}{l}\text { Less private provision and } \\
\text { volume incentives but more } \\
\text { regulation of provider prices }\end{array}$ & $\begin{array}{l}\text { Assess whether the current compensation system for } \\
\text { out-patient care (fee-for-services combined with } \\
\text { capitation) should not be reformed so as to reduce the } \\
\text { very high number of consultations per capita and to } \\
\text { promote high quality of care }\end{array}$ \\
\hline & $\begin{array}{l}\text { Low administrative } \\
\text { costs }\end{array}$ & & & & & $\begin{array}{l}\text { Improve availability of internationally comparable data } \\
\text { on the quality of care }\end{array}$ \\
\hline
\end{tabular}




\begin{tabular}{|c|c|c|c|c|c|c|}
\hline & $\begin{array}{l}\text { Efficiency and } \\
\text { quality }\end{array}$ & $\begin{array}{l}\text { Prices and physical } \\
\text { resources }\end{array}$ & $\begin{array}{l}\text { Activity and } \\
\text { consumption }\end{array}$ & $\begin{array}{l}\text { Financing and } \\
\text { spending mix }\end{array}$ & Policies and institutions & $\begin{array}{l}\text { Weaknesses and policy inconsistencies } \\
\text { emerging from the set of indicators }\end{array}$ \\
\hline \multirow[t]{4}{*}{ Greece } & $\begin{array}{l}\text { Lower DEA score. } \\
\text { About average } \\
\text { amenable mortality } \\
\text { rate }\end{array}$ & & $\begin{array}{l}\text { Higher level of } \\
\text { health care } \\
\text { spending to GDP } \\
\text { ratio }\end{array}$ & $\begin{array}{l}\text { Lower public funding } \\
\text { share. Higher out-of- } \\
\text { pocket payments }\end{array}$ & Rather low depth of coverage & $\begin{array}{l}\text { The Greek health care system is difficult to assess } \\
\text { with the existing set of indicators, given its very } \\
\text { fragmented nature (including the rather large } \\
\text { parallel system). Internationally comparable data } \\
\text { are also often missing, in particular on the } \\
\text { allocation of spending across sub-sectors and on } \\
\text { the quality of care }\end{array}$ \\
\hline & $\begin{array}{l}\text { Mixed signals on } \\
\text { acute care (output) } \\
\text { efficiency }\end{array}$ & & & & $\begin{array}{l}\text { Less choice of provider and } \\
\text { more price signals on users } \\
\text { (often in the form of informal } \\
\text { payments) }\end{array}$ & Improve information on prices for users \\
\hline & & $\begin{array}{l}\text { More doctors and } \\
\text { students per capita, } \\
\text { less nurses }\end{array}$ & & & $\begin{array}{l}\text { Regulation of provider prices } \\
\text { are often not fully complied } \\
\text { with }\end{array}$ & $\begin{array}{l}\text { Introducing a hybrid compensation system for } \\
\text { physicians (capitation payments and fee-for- } \\
\text { services) should be considered. For hospitals, } \\
\text { moving from a per-diem and retrospective payment } \\
\text { approach to a DRG system could be an option to } \\
\text { promote value for money }\end{array}$ \\
\hline & & $\begin{array}{l}\text { Higher relative } \\
\text { income of nurses }\end{array}$ & & & Less priority setting & $\begin{array}{l}\text { To control health care spending better, stricter } \\
\text { budget norms and better priority setting should be } \\
\text { considered }\end{array}$ \\
\hline \multirow[t]{4}{*}{ Japan } & $\begin{array}{l}\text { High DEA score and } \\
\text { low amenable } \\
\text { mortality rate }\end{array}$ & & & $\begin{array}{l}\text { Large public funding share } \\
\text { and small share for out-of- } \\
\text { pocket payments }\end{array}$ & & $\begin{array}{l}\text { Overall (DEA) efficiency is high. Two main features } \\
\text { are however striking: the large reliance on } \\
\text { hospitals for long-term care and the very large } \\
\text { number of consultations per capita and per doctor }\end{array}$ \\
\hline & $\begin{array}{l}\text { Rather low } \\
\text { output/hospital } \\
\text { efficiency, with very } \\
\text { low turnover rate for } \\
\text { acute care beds }\end{array}$ & $\begin{array}{l}\text { More acute care } \\
\text { beds and high-tech } \\
\text { equipment per capita }\end{array}$ & $\begin{array}{l}\text { Less hospital } \\
\text { discharges per } \\
\text { capita }\end{array}$ & & $\begin{array}{l}\text { More private provision, higher } \\
\text { volume incentives for } \\
\text { providers coupled with strict } \\
\text { regulation on provider prices }\end{array}$ & $\begin{array}{l}\text { Consider options to reduce the use of hospitals for } \\
\text { long-term stays. Reforming the hospital payment } \\
\text { system (by extending the case-mix element) } \\
\text { should be examined }\end{array}$ \\
\hline & $\begin{array}{l}\text { About average } \\
\text { quality of out-patient } \\
\text { care and very high } \\
\text { number of } \\
\text { consultations per } \\
\text { doctor }\end{array}$ & $\begin{array}{l}\text { Less doctors and } \\
\text { medical students per } \\
\text { capita }\end{array}$ & $\begin{array}{l}\text { Much more } \\
\text { doctor } \\
\text { consultations per } \\
\text { capita }\end{array}$ & & $\begin{array}{l}\text { More choice among providers } \\
\text { but less information on quality } \\
\text { and price of services. No gate- } \\
\text { keeping }\end{array}$ & $\begin{array}{l}\text { Consider introducing gate-keeping and/or a reform } \\
\text { of the payment system (e.g. combining some } \\
\text { capitation with the existing fee-for-services) to } \\
\text { reduce the number of consultations. Increase } \\
\text { information on quality and prices of services to } \\
\text { reinforce pressures on providers to provide high } \\
\text { quality services }\end{array}$ \\
\hline & $\begin{array}{l}\text { Lower administrative } \\
\text { costs }\end{array}$ & & & & $\begin{array}{l}\text { More decentralisation; less } \\
\text { consistency; more priority } \\
\text { setting; softer budget } \\
\text { constraint }\end{array}$ & \\
\hline
\end{tabular}


ECO/WKP(2010)25

\begin{tabular}{|c|c|c|c|c|c|c|}
\hline & $\begin{array}{l}\text { Efficiency and } \\
\text { quality }\end{array}$ & $\begin{array}{l}\text { Prices and physical } \\
\text { resources }\end{array}$ & $\begin{array}{l}\text { Activity and } \\
\text { consumption }\end{array}$ & $\begin{array}{l}\text { Financing and } \\
\text { spending mix }\end{array}$ & Policies and institutions & $\begin{array}{l}\text { Weaknesses and policy inconsistencies } \\
\text { emerging from the set of indicators }\end{array}$ \\
\hline \multirow[t]{4}{*}{ Korea } & $\begin{array}{l}\text { High DEA score, } \\
\text { with about average } \\
\text { amenable mortality } \\
\text { rate }\end{array}$ & $\begin{array}{l}\text { Lower health care } \\
\text { spending per capita } \\
\text { and as a share of } \\
\text { GDP }\end{array}$ & & $\begin{array}{l}\text { Lower public funded } \\
\text { share; higher out-of-pocket } \\
\text { payments }\end{array}$ & Lower depth of coverage & $\begin{array}{l}\text { Assess the impact of the rather low scope and } \\
\text { depth of the basic insurance package on equity in } \\
\text { access to health care services }\end{array}$ \\
\hline & $\begin{array}{l}\text { Rather low } \\
\text { output/acute care } \\
\text { efficiency }\end{array}$ & $\begin{array}{l}\text { More acute care } \\
\text { beds and high-tech } \\
\text { equipment per capita } \\
\text { than the OECD } \\
\text { average }\end{array}$ & $\begin{array}{l}\text { Fewer hospital } \\
\text { discharges per } \\
\text { capita }\end{array}$ & Lower in-patient share & $\begin{array}{l}\text { No gate-keeping and higher } \\
\text { price signals on users }\end{array}$ & \\
\hline & $\begin{array}{l}\text { Rather high quality } \\
\text { of out-patient and } \\
\text { preventive care and } \\
\text { very high number of } \\
\text { consultations per } \\
\text { doctor }\end{array}$ & $\begin{array}{l}\text { Less doctors, nurses } \\
\text { and medical } \\
\text { students per capita }\end{array}$ & $\begin{array}{l}\text { More doctor } \\
\text { consultations per } \\
\text { capita }\end{array}$ & Higher drug share & $\begin{array}{l}\text { More private provision and } \\
\text { provider incentives to raise } \\
\text { volume coupled with strict } \\
\text { regulation on provider prices. } \\
\text { Lower regulation of resources }\end{array}$ & $\begin{array}{l}\text { Consider introducing gate-keeping and/or a reform } \\
\text { of the payment system for GPs (e.g. combining an } \\
\text { element of capitation with the existing fee-for- } \\
\text { services) to reduce the number of doctors' } \\
\text { consultations }\end{array}$ \\
\hline & & & & & $\begin{array}{l}\text { Less decentralisation, higher } \\
\text { consistency, delegation and } \\
\text { priority setting; softer budget } \\
\text { constraint }\end{array}$ & \\
\hline \multirow[t]{4}{*}{ Luxembourg } & $\begin{array}{l}\text { Lower DEA score; } \\
\text { lower amenable } \\
\text { mortality rates }\end{array}$ & $\begin{array}{l}\text { Relatively low health } \\
\text { care spending as a } \\
\text { share of GDP but } \\
\text { high in per capita } \\
\text { terms }\end{array}$ & & $\begin{array}{l}\text { Higher public funded } \\
\text { share. Lower co-payments }\end{array}$ & $\begin{array}{l}\text { Less market mechanisms for } \\
\text { the basic insurance and } \\
\text { additional coverage }\end{array}$ & \\
\hline & $\begin{array}{l}\text { Mixed scores on } \\
\text { output/acute care } \\
\text { efficiency }\end{array}$ & $\begin{array}{l}\text { Less doctors per } \\
\text { capita }\end{array}$ & & Higher in-patient share & $\begin{array}{l}\text { More private provision and } \\
\text { little information on the quality } \\
\text { and price of services. Soft } \\
\text { regulation on prices } \\
\text { reimbursed by third-party } \\
\text { payers. }\end{array}$ & $\begin{array}{l}\text { Develop strategies to increase efficiency in the in- } \\
\text { patient care sector. Introducing a DRG payment } \\
\text { system for hospitals and improving the availability } \\
\text { of information on prices and quality of services } \\
\text { would be useful }\end{array}$ \\
\hline & & $\begin{array}{l}\text { More nurses per } \\
\text { capita }\end{array}$ & $\begin{array}{l}\text { Less doctor } \\
\text { consultations per } \\
\text { capita }\end{array}$ & & $\begin{array}{l}\text { Ample choice of providers with } \\
\text { no gate-keeping }\end{array}$ & $\begin{array}{l}\text { Introducing a gate-keeping system and/or } \\
\text { increasing out-of-pocket payments for out-patient } \\
\text { care may be options to control spending growth }\end{array}$ \\
\hline & $\begin{array}{l}\text { Very high } \\
\text { administrative costs }\end{array}$ & & & Lower drug share & Little priority setting & $\begin{array}{l}\text { Examine the reasons behind the very high } \\
\text { administrative costs. Improve internationally } \\
\text { comparable data on the quality of care }\end{array}$ \\
\hline
\end{tabular}


ECO/WKP(2010)25

\begin{tabular}{|c|c|c|c|c|c|c|}
\hline & $\begin{array}{l}\text { Efficiency and } \\
\text { quality }\end{array}$ & $\begin{array}{l}\text { Prices and physical } \\
\text { resources }\end{array}$ & $\begin{array}{l}\text { Activity and } \\
\text { consumption }\end{array}$ & $\begin{array}{l}\text { Financing and } \\
\text { spending mix }\end{array}$ & Policies and institutions & $\begin{array}{l}\text { Weaknesses and policy inconsistencies } \\
\text { emerging from the set of indicators }\end{array}$ \\
\hline \multirow{5}{*}{$\begin{array}{l}\text { GROUP } \\
\text { Iceland }\end{array}$} & \multicolumn{6}{|c|}{ Mostly public insurance. Users are given ample choice of providers but private supply is limited and prices tightly regulated. Gate-keeping is virtually inexistent. } \\
\hline & $\begin{array}{l}\text { High DEA score, low } \\
\text { amenable mortality } \\
\text { rate and low } \\
\text { inequalities in health } \\
\text { status }\end{array}$ & $\begin{array}{l}\text { Rather high } \\
\text { spending to GDP } \\
\text { ratio and per capita }\end{array}$ & & $\begin{array}{l}\text { Higher share of public, } \\
\text { largely tax, funding and } \\
\text { low out-of-pocket share }\end{array}$ & $\begin{array}{l}\text { Generous basic insurance } \\
\text { coverage }\end{array}$ & $\begin{array}{l}\text { In containing public spending on health, the focus } \\
\text { should be on the in-patient care sector. Hospital } \\
\text { budgets are largely independent on the level of } \\
\text { activity. There are few regulations which apply to } \\
\text { the level of human resources and equipment, } \\
\text { which is high by OECD standards. Two alternative } \\
\text { strategies may be envisaged: i) tightening both } \\
\text { hospital budgets and controls on resources; } \\
\text { ii) linking hospital budgets to their level of activity. } \\
\text { The first approach will help better controlling health } \\
\text { care spending and could be reinforced via a } \\
\text { tougher budget constraint while the second } \\
\text { approach would promote efficiency gains without } \\
\text { having an automatic impact on public spending }\end{array}$ \\
\hline & & $\begin{array}{l}\text { More doctors, } \\
\text { nurses, medical } \\
\text { students, MRls and } \\
\text { scanners per capita }\end{array}$ & $\begin{array}{l}\text { About average } \\
\text { number of } \\
\text { consultations and } \\
\text { hospital } \\
\text { discharges per } \\
\text { capita }\end{array}$ & Very high in-patient share & $\begin{array}{l}\text { Ample user choice of } \\
\text { providers and no gate-keeping } \\
\text { with little information on prices } \\
\text { and quality }\end{array}$ & $\begin{array}{l}\text { Introducing gate-keeping could contribute to } \\
\text { mitigate spending pressures in the in-patient care } \\
\text { sector }\end{array}$ \\
\hline & $\begin{array}{l}\text { Rather high quality } \\
\text { of out-patient and } \\
\text { preventive care }\end{array}$ & & & & $\begin{array}{l}\text { Little private provision and } \\
\text { provider incentives, with heavy } \\
\text { regulation of prices. Less } \\
\text { regulations of resources }\end{array}$ & $\begin{array}{l}\text { The high number of health professionals and low } \\
\text { number of consultations per doctor is striking. } \\
\text { Achieving the same quality of health care services } \\
\text { with fewer human resources could be an objective. } \\
\text { Incorporating an activity-based component to the } \\
\text { existing salary system for health professionals } \\
\text { could be considered }\end{array}$ \\
\hline & & $\begin{array}{l}\text { High relative income } \\
\text { of (salaried) GPs but } \\
\text { low relative income } \\
\text { of specialists }\end{array}$ & & & $\begin{array}{l}\text { Little decentralisation and } \\
\text { rather soft constraint on public } \\
\text { spending via the budget } \\
\text { process }\end{array}$ & \\
\hline
\end{tabular}




\begin{tabular}{|c|c|c|c|c|c|c|}
\hline & Efficiency and quality & $\begin{array}{l}\text { Prices and physical } \\
\text { resources }\end{array}$ & $\begin{array}{l}\text { Activity and } \\
\text { consumption }\end{array}$ & $\begin{array}{l}\text { Financing and } \\
\text { spending mix }\end{array}$ & Policies and institutions & $\begin{array}{l}\text { Weaknesses and policy inconsistencies } \\
\text { emerging from the set of indicators }\end{array}$ \\
\hline \multirow[t]{4}{*}{ Sweden } & $\begin{array}{l}\text { High DEA score } \\
\text { compared to the OECD } \\
\text { average, low amenable } \\
\text { mortality rate and low } \\
\text { inequalities in health } \\
\text { status }\end{array}$ & & $\begin{array}{l}\text { Above average } \\
\text { spending per } \\
\text { capita }\end{array}$ & $\begin{array}{l}\text { Large public share } \\
\text { mostly tax-financed and } \\
\text { very limited role of out- } \\
\text { of-pocket payments and } \\
\text { private health insurance }\end{array}$ & $\begin{array}{l}\text { Basic insurance coverage is } \\
\text { slightly less generous } \\
\text { (physiotherapies and } \\
\text { eyeglasses are not covered; } \\
\text { large co-payments apply to } \\
\text { dental care) }\end{array}$ & \\
\hline & $\begin{array}{l}\text { Rather high output } \\
\text { efficiency in the in-patient } \\
\text { care sector }\end{array}$ & $\begin{array}{l}\text { More doctors and } \\
\text { nurses per capita, } \\
\text { less acute care beds }\end{array}$ & & & $\begin{array}{l}\text { Ample user choice of } \\
\text { providers and no gate-keeping }\end{array}$ & $\begin{array}{l}\text { The high number of health professionals and low } \\
\text { number of consultations per doctor is striking. } \\
\text { Achieving the same quality of health care services } \\
\text { with fewer human resources could be an objective. } \\
\text { Incorporating an activity-based component to the } \\
\text { existing salary system for health professionals could } \\
\text { be considered }\end{array}$ \\
\hline & $\begin{array}{l}\text { Rather high quality of out- } \\
\text { patient and preventive } \\
\text { care but low number of } \\
\text { consultations per doctor }\end{array}$ & $\begin{array}{l}\text { Low relative income } \\
\text { level of (salaried) } \\
\text { GPs and specialists }\end{array}$ & $\begin{array}{l}\text { Less } \\
\text { consultations per } \\
\text { capita }\end{array}$ & $\begin{array}{l}\text { High share of out-patient } \\
\text { care }\end{array}$ & $\begin{array}{l}\text { Very little private provision, } \\
\text { low volume incentives and } \\
\text { little information on the quality } \\
\text { of services. Heavy regulation } \\
\text { of prices }\end{array}$ & $\begin{array}{l}\text { Improving information on the quality of services } \\
\text { could reinforce pressures on providers to increase } \\
\text { the quality of care }\end{array}$ \\
\hline & $\begin{array}{l}\text { Lower administrative } \\
\text { costs }\end{array}$ & & & & $\begin{array}{l}\text { Tight budget constraint. High } \\
\text { degree of decentralisation but } \\
\text { low degree of consistency in } \\
\text { responsibility assignment }\end{array}$ & $\begin{array}{l}\text { Efforts to increase consistency in the allocation of } \\
\text { resources across government levels could contribute } \\
\text { to raise spending efficiency }\end{array}$ \\
\hline \multirow[t]{4}{*}{ Turkey } & $\begin{array}{l}\text { High DEA score but still } \\
\text { lower health status (life } \\
\text { expectancy) }\end{array}$ & $\begin{array}{l}\text { Health care } \\
\text { spending per capita } \\
\text { and as a share of } \\
\text { GDP both remain } \\
\text { well below the } \\
\text { OECD average }\end{array}$ & & & $\begin{array}{l}\text { A large share of the population } \\
\text { is still not covered by a basic } \\
\text { insurance package }\end{array}$ & $\begin{array}{l}\text { Pursue efforts to increase population coverage for } \\
\text { the basic insurance package }\end{array}$ \\
\hline & $\begin{array}{l}\text { Rather high output } \\
\text { efficiency in the in-patient } \\
\text { care sector, except a low } \\
\text { occupancy rate of beds }\end{array}$ & $\begin{array}{l}\text { Less acute care } \\
\text { beds, high-tech } \\
\text { equipment and } \\
\text { nurses per capita }\end{array}$ & $\begin{array}{l}\text { Less hospital } \\
\text { discharges per } \\
\text { capita }\end{array}$ & $\begin{array}{l}\text { Low share of in-patient } \\
\text { care }\end{array}$ & $\begin{array}{l}\text { Ample user choice of } \\
\text { providers and no gate-keeping }\end{array}$ & $\begin{array}{l}\text { Consider strategies to manage efficiently existing } \\
\text { hospital beds. Incorporating some elements of } \\
\text { activity-based funding to the current line-item funding } \\
\text { for hospitals could be considered }\end{array}$ \\
\hline & $\begin{array}{l}\text { Data missing on the } \\
\text { quality of care and on } \\
\text { administrative costs }\end{array}$ & $\begin{array}{l}\text { Less doctors per } \\
\text { capita }\end{array}$ & & $\begin{array}{l}\text { High share of } \\
\text { expenditure on drugs }\end{array}$ & $\begin{array}{l}\text { Tight regulation of resources } \\
\text { and prices, combined with little } \\
\text { private provision and volume } \\
\text { incentives }\end{array}$ & $\begin{array}{l}\text { Improve availability of internationally comparable } \\
\text { data on the quality of care, compensation levels of } \\
\text { health professionals and administrative costs }\end{array}$ \\
\hline & & & & & $\begin{array}{l}\text { Less decentralisation coupled } \\
\text { with little priority setting and } \\
\text { expenditure control via the } \\
\text { budget process }\end{array}$ & $\begin{array}{l}\text { Strengthening the budget and prioritisation process } \\
\text { (e.g. by introducing expenditure targets) could help } \\
\text { better controlling both the level and allocation of } \\
\text { public health care spending }\end{array}$ \\
\hline
\end{tabular}




\begin{tabular}{|c|c|c|c|c|c|c|}
\hline & Efficiency and quality & $\begin{array}{l}\text { Prices and physical } \\
\text { resources }\end{array}$ & $\begin{array}{l}\text { Activity and } \\
\text { consumption }\end{array}$ & $\begin{array}{l}\text { Financing and } \\
\text { spending mix }\end{array}$ & Policies and institutions & $\begin{array}{l}\text { Weaknesses and policy inconsistencies } \\
\text { emerging from the set of indicators }\end{array}$ \\
\hline GROUP 5: & \multicolumn{6}{|c|}{$\begin{array}{l}\text { Mostly public insurance. Health care is provided by a heavily regulated public system and the role of gate-keeping is important. Patient choice among providers is limited and the budget } \\
\text { constraint imposed via the budget process is rather soft. }\end{array}$} \\
\hline \multirow[t]{4}{*}{ Denmark } & $\begin{array}{l}\text { Lower DEA score but } \\
\text { slightly below-average } \\
\text { health inequalities }\end{array}$ & $\begin{array}{l}\text { Spending per capita } \\
\text { and as a share of } \\
\text { GDP stand above } \\
\text { the OECD and group } \\
\text { averages }\end{array}$ & & Higher tax-financed shares & $\begin{array}{l}\text { Less market for the "over-the- } \\
\text { basic" segment }\end{array}$ & \\
\hline & $\begin{array}{l}\text { Rather high } \\
\text { output/hospital efficiency }\end{array}$ & $\begin{array}{l}\text { More nurses and } \\
\text { medical students per } \\
\text { capita. Less acute } \\
\text { care beds per capita }\end{array}$ & $\begin{array}{l}\text { More hospital } \\
\text { discharges }\end{array}$ & Higher in-patient share & Less price signals on users & \\
\hline & $\begin{array}{l}\text { Mixed scores on the } \\
\text { quality of preventive and } \\
\text { out-patient care }\end{array}$ & $\begin{array}{l}\text { Lower income level } \\
\text { for specialists, high } \\
\text { income level for } \\
\text { nurses }\end{array}$ & $\begin{array}{l}\text { More doctor } \\
\text { consultations }\end{array}$ & Higher out-patient share & More private provision & $\begin{array}{l}\text { Introducing co-payments for visits to GPs could } \\
\text { help avoid excessive demand }\end{array}$ \\
\hline & $\begin{array}{l}\text { Lower administrative } \\
\text { costs }\end{array}$ & & & & $\begin{array}{l}\text { Less decentralisation and } \\
\text { consistency in responsibility } \\
\text { assignment, less regulation of } \\
\text { resources }\end{array}$ & $\begin{array}{l}\text { Enhanced priority setting (in particular the } \\
\text { definition of the benefit basket and the monitoring } \\
\text { of public health objectives) and greater } \\
\text { consistency in the allocation of responsibilities } \\
\text { across levels of government could deliver } \\
\text { efficiency gains }\end{array}$ \\
\hline \multirow[t]{4}{*}{ Finland } & $\begin{array}{l}\text { Low DEA score and high } \\
\text { inequalities in health } \\
\text { status }\end{array}$ & $\begin{array}{l}\text { About average } \\
\text { health care spending } \\
\text { per capita }\end{array}$ & & Higher tax-financed shares & $\begin{array}{l}\text { Less market orientation for the } \\
\text { "over-the-basic" segment }\end{array}$ & $\begin{array}{l}\text { Examine the reasons behind high inequalities in } \\
\text { health status. }\end{array}$ \\
\hline & $\begin{array}{l}\text { Rather low } \\
\text { output/hospital efficiency }\end{array}$ & $\begin{array}{l}\text { More acute care } \\
\text { beds per capita }\end{array}$ & $\begin{array}{l}\text { More hospital } \\
\text { discharges per } \\
\text { capita }\end{array}$ & Higher in-patient share & $\begin{array}{l}\text { Less gate-keeping and choice } \\
\text { of provider. }\end{array}$ & $\begin{array}{l}\text { Reinforcing control on resources, priority setting } \\
\text { and gate-keeping arrangements could contribute } \\
\text { to shift resources from in-patient to out-patient } \\
\text { care }\end{array}$ \\
\hline & $\begin{array}{l}\text { Mixed scores on the } \\
\text { quality of preventive and } \\
\text { out-patient care }\end{array}$ & & $\begin{array}{l}\text { Less doctor } \\
\text { consultations per } \\
\text { capita }\end{array}$ & Lower out-patient share & $\begin{array}{l}\text { Little private provision but } \\
\text { more incentives to raise } \\
\text { volume of care in the hospital } \\
\text { sector. Out-patient physicians } \\
\text { are paid on a salary basis. }\end{array}$ & $\begin{array}{l}\text { Assess whether reform of the compensation } \\
\text { system for physicians could help to improve the } \\
\text { quality of out-patient care }\end{array}$ \\
\hline & Low administrative costs & $\begin{array}{l}\text { Much lower relative } \\
\text { income level of } \\
\text { health care } \\
\text { professionals }\end{array}$ & & & $\begin{array}{l}\text { Less regulation of resources, } \\
\text { priority setting and budget } \\
\text { constraint. More regulation of } \\
\text { prices }\end{array}$ & \\
\hline
\end{tabular}




\begin{tabular}{|c|c|c|c|c|c|c|}
\hline & Efficiency and quality & $\begin{array}{l}\text { Prices and physical } \\
\text { resources }\end{array}$ & $\begin{array}{l}\text { Activity and } \\
\text { consumption }\end{array}$ & $\begin{array}{l}\text { Financing and } \\
\text { spending mix }\end{array}$ & Policies and institutions & $\begin{array}{l}\text { Weaknesses and policy inconsistencies } \\
\text { emerging from the set of indicators }\end{array}$ \\
\hline \multirow[t]{4}{*}{ Mexico } & $\begin{array}{l}\text { High DEA score but } \\
\text { amenable mortality } \\
\text { remains high and } \\
\text { information on } \\
\text { inequalities in health } \\
\text { status is lacking }\end{array}$ & $\begin{array}{l}\text { Spending per capita } \\
\text { and as a share of } \\
\text { GDP remain low }\end{array}$ & & $\begin{array}{l}\text { Lower public spending } \\
\text { share and higher out-of- } \\
\text { pocket payments }\end{array}$ & $\begin{array}{l}\text { Less breadth and depth of the } \\
\text { basic insurance coverage, } \\
\text { despite some choice among } \\
\text { insurers given to citizens }\end{array}$ & $\begin{array}{l}\text { Continued efforts to achieve universal health } \\
\text { insurance coverage would help improving the } \\
\text { health status of the population. Developing } \\
\text { internationally comparable data on inequalities in } \\
\text { health status and on the quality of care should } \\
\text { also be considered }\end{array}$ \\
\hline & $\begin{array}{l}\text { High scores on } \\
\text { output/hospital efficiency } \\
\text { except a very low } \\
\text { occupancy rate for acute } \\
\text { care beds }\end{array}$ & $\begin{array}{l}\text { Less nurses, high- } \\
\text { tech equipment and } \\
\text { acute care beds per } \\
\text { capita }\end{array}$ & $\begin{array}{l}\text { Less hospital } \\
\text { discharges per } \\
\text { capita }\end{array}$ & Lower in-patient share & $\begin{array}{l}\text { More price signals on users } \\
\text { but little choice across } \\
\text { providers }\end{array}$ & $\begin{array}{l}\text { Allowing insurers to contract with any provider } \\
\text { would reinforce efficiency pressures on providers }\end{array}$ \\
\hline & $\begin{array}{l}\text { Little internationally } \\
\text { comparable data on the } \\
\text { quality of care }\end{array}$ & $\begin{array}{l}\text { Less doctors per } \\
\text { capita }\end{array}$ & $\begin{array}{l}\text { Less doctor } \\
\text { consultations per } \\
\text { capita }\end{array}$ & Higher drug share & $\begin{array}{l}\text { Less regulation of provider } \\
\text { prices }\end{array}$ & \\
\hline & $\begin{array}{l}\text { Very high administrative } \\
\text { costs }\end{array}$ & $\begin{array}{l}\text { High relative income } \\
\text { of salaried nurses } \\
\text { and GPs }\end{array}$ & & & $\begin{array}{l}\text { Less priority setting. Little } \\
\text { decentralisation but some } \\
\text { overlap in responsibilities } \\
\text { across levels of government. } \\
\text { Strict regulation of medical } \\
\text { resources. }\end{array}$ & $\begin{array}{l}\text { Explore ways to reduce administrative costs. } \\
\text { Consolidating some insurance funds or } \\
\text { establishing a unified claims management } \\
\text { system could be options. Efforts to better set } \\
\text { health care priorities and to improve consistency } \\
\text { in responsibility assignment across levels of } \\
\text { government should also be envisaged }\end{array}$ \\
\hline \multirow[t]{4}{*}{ Portugal } & $\begin{array}{l}\text { Above average DEA } \\
\text { score }\end{array}$ & $\begin{array}{l}\text { Below average } \\
\text { health care spending } \\
\text { per capita }\end{array}$ & & $\begin{array}{l}\text { High share of tax financing } \\
\text { and out-of-pocket } \\
\text { payments }\end{array}$ & $\begin{array}{l}\text { Little market orientation for } \\
\text { insurance coverage }\end{array}$ & \\
\hline & $\begin{array}{l}\text { Rather low efficiency } \\
\text { scores in the in-patient } \\
\text { (acute) care sector }\end{array}$ & $\begin{array}{l}\text { Little acute care } \\
\text { beds per capita }\end{array}$ & $\begin{array}{l}\text { Less hospital } \\
\text { discharges per } \\
\text { capita }\end{array}$ & High out-patient share & $\begin{array}{l}\text { Limited choice of provider and } \\
\text { more gate-keeping }\end{array}$ & $\begin{array}{l}\text { Devise strategies to improve efficiency in the in- } \\
\text { patient care sector and raise the number of } \\
\text { consultations per doctor. Combining the existing } \\
\text { wage system for physicians and prospective } \\
\text { global budget for hospitals with some elements } \\
\text { of activity-based payments (fee-for-services or } \\
\text { preferably DRGs) could be an option }\end{array}$ \\
\hline & $\begin{array}{l}\text { Mixed signals on the } \\
\text { quality of (out- } \\
\text { patient/preventive) care. } \\
\text { Low number of } \\
\text { consultations per doctor }\end{array}$ & $\begin{array}{l}\text { More doctors but } \\
\text { less nurses and } \\
\text { medical students per } \\
\text { capita }\end{array}$ & $\begin{array}{l}\text { Less doctor } \\
\text { consultations per } \\
\text { capita }\end{array}$ & High drug share & $\begin{array}{l}\text { Very low private provision and } \\
\text { volume incentives. More } \\
\text { regulation of prices billed by } \\
\text { providers. Low user } \\
\text { information }\end{array}$ & $\begin{array}{l}\text { Increasing the availability of information on the } \\
\text { quality of services could create pressures on } \\
\text { suppliers to increase quality }\end{array}$ \\
\hline & Low administrative costs & $\begin{array}{l}\text { High relative income } \\
\text { of nurses and low } \\
\text { income of specialists }\end{array}$ & & & $\begin{array}{l}\text { Less decentralisation but still } \\
\text { little consistency in } \\
\text { responsibility assignment } \\
\text { across levels of government }\end{array}$ & $\begin{array}{l}\text { Efforts to increase consistency in the allocation } \\
\text { of resources across government levels could } \\
\text { contribute to raise spending efficiency }\end{array}$ \\
\hline
\end{tabular}


ECO/WKP(2010)25

\begin{tabular}{|c|c|c|c|c|c|c|}
\hline & Efficiency and quality & $\begin{array}{l}\text { Prices and physical } \\
\text { resources }\end{array}$ & $\begin{array}{l}\text { Activity and } \\
\text { consumption }\end{array}$ & $\begin{array}{l}\text { Financing and } \\
\text { spending mix }\end{array}$ & Policies and institutions & $\begin{array}{l}\text { Weaknesses and policy inconsistencies } \\
\text { emerging from the set of indicators }\end{array}$ \\
\hline \multirow[t]{4}{*}{ Spain } & $\begin{array}{l}\text { High DEA score and low } \\
\text { inequalities in health } \\
\text { status }\end{array}$ & $\begin{array}{l}\text { Spending per capita } \\
\text { remains below the } \\
\text { OECD average }\end{array}$ & & & $\begin{array}{l}\text { More reliance on } \mathrm{PHI} \text { to } \\
\text { provide additional health } \\
\text { coverage }\end{array}$ & \\
\hline & $\begin{array}{l}\text { Mixed signals on output } \\
\text { efficiency in the in- } \\
\text { patient (acute) sector }\end{array}$ & $\begin{array}{l}\text { Less acute care } \\
\text { beds and nurses }\end{array}$ & $\begin{array}{l}\text { Less hospital } \\
\text { discharges per } \\
\text { capita }\end{array}$ & Lower in-patient care & & \\
\hline & $\begin{array}{l}\text { High quality of out- } \\
\text { patient and preventive } \\
\text { care }\end{array}$ & $\begin{array}{l}\text { More doctors and } \\
\text { less medical } \\
\text { students }\end{array}$ & $\begin{array}{l}\text { More doctor } \\
\text { consultations per } \\
\text { capita }\end{array}$ & Higher out-patient share & $\begin{array}{l}\text { Little choice of providers. Less } \\
\text { private provision (in particular } \\
\text { for out-patient care) and } \\
\text { volume incentives. Heavily } \\
\text { regulated prices and } \\
\text { resources }\end{array}$ & \\
\hline & Low administrative costs & & & & $\begin{array}{l}\text { Higher decentralisation but } \\
\text { high degree of consistency. } \\
\text { User information on quality of } \\
\text { price of services remains } \\
\text { limited }\end{array}$ & $\begin{array}{l}\text { Better sharing experiences and improving } \\
\text { information on the quality of services across } \\
\text { regions could strengthen pressures for improving } \\
\text { efficiency in health care provision }\end{array}$ \\
\hline & \multicolumn{6}{|c|}{$\begin{array}{l}\text { Mostly public insurance. Health care is mainly provided by a heavily regulated public system, with strict gate-keeping, little decentralisation and a tight spending limit imposed via the budget } \\
\text { process. }\end{array}$} \\
\hline \multirow[t]{4}{*}{ Hungary } & $\begin{array}{l}\text { Low DEA score, high } \\
\text { rate of amenable } \\
\text { mortality, high } \\
\text { inequalities in health } \\
\text { status }\end{array}$ & $\begin{array}{l}\text { Spending per capita } \\
\text { and as a share of } \\
\text { GDP remain below } \\
\text { the OECD average }\end{array}$ & & $\begin{array}{l}\text { Relatively high share of } \\
\text { out-of-pocket payments }\end{array}$ & & $\begin{array}{l}\text { Examine the main reasons behind high } \\
\text { inequalities in health status, and in particular the } \\
\text { role of large (largely unofficial) out-of-pocket } \\
\text { payments and regional disparities in access }\end{array}$ \\
\hline & $\begin{array}{l}\text { Rather short durations of } \\
\text { stay in the acute care } \\
\text { hospitals but low } \\
\text { occupancy rate of acute } \\
\text { care beds }\end{array}$ & $\begin{array}{l}\text { More acute beds but } \\
\text { less high-tech } \\
\text { equipment per capita }\end{array}$ & $\begin{array}{l}\text { More hospital } \\
\text { discharges per } \\
\text { capita }\end{array}$ & Very low out-patient share & $\begin{array}{l}\text { More choice of providers, } \\
\text { combined with tight gate- } \\
\text { keeping arrangements. Little } \\
\text { incentives to increase volumes } \\
\text { of care }\end{array}$ & $\begin{array}{l}\text { Consider increasing the role of preventive and } \\
\text { out-patient care, which would contribute to } \\
\text { reducing drug consumption and in-patient care. } \\
\text { Adjusting the level and mode of physician } \\
\text { compensation (currently capitation for GPs and } \\
\text { salary for specialists) may be warranted. This } \\
\text { would in turn allow strengthening the gate- } \\
\text { keeping role of GPs. }\end{array}$ \\
\hline & $\begin{array}{l}\text { A high rate of cataract } \\
\text { surgery performed in the } \\
\text { in-patient care sector } \\
\text { which may signal a mis- } \\
\text { allocation of resources } \\
\text { across sectors }\end{array}$ & $\begin{array}{l}\text { Less doctors and } \\
\text { nurses but more } \\
\text { medical students }\end{array}$ & $\begin{array}{l}\text { More doctor } \\
\text { consultations per } \\
\text { capita }\end{array}$ & & $\begin{array}{l}\text { Less binding regulation on } \\
\text { provider prices but more } \\
\text { regulation on health care } \\
\text { resources. Less priority setting }\end{array}$ & $\begin{array}{l}\text { Improve internationally comparable data on } \\
\text { health care quality }\end{array}$ \\
\hline & Low administrative costs & $\begin{array}{l}\text { Very low relative } \\
\text { compensation level } \\
\text { of health care } \\
\text { professionals }\end{array}$ & & High drug share & $\begin{array}{l}\text { Little decentralisation but still } \\
\text { some overlapping in } \\
\text { responsibility assignment } \\
\text { across levels of government }\end{array}$ & $\begin{array}{l}\text { Reinforcing priority setting may also contribute to } \\
\text { a better balance of health care spending } \\
\text { between out-patient, preventive and in-patient } \\
\text { care }\end{array}$ \\
\hline
\end{tabular}




\begin{tabular}{|c|c|c|c|c|c|c|}
\hline & Efficiency and quality & $\begin{array}{l}\text { Prices and physical } \\
\text { resources }\end{array}$ & $\begin{array}{l}\text { Activity and } \\
\text { consumption }\end{array}$ & $\begin{array}{l}\text { Financing and } \\
\text { spending mix }\end{array}$ & Policies and institutions & $\begin{array}{l}\text { Weaknesses and policy inconsistencies } \\
\text { emerging from the set of indicators }\end{array}$ \\
\hline \multirow[t]{4}{*}{ Ireland } & $\begin{array}{l}\text { Low DEA score but high } \\
\text { equity score }\end{array}$ & $\begin{array}{l}\text { Spending per capita } \\
\text { slightly above } \\
\text { average }\end{array}$ & & $\begin{array}{l}\text { Higher tax-financed and } \\
\text { private insurance share }\end{array}$ & $\begin{array}{l}\text { More limited basket of goods } \\
\text { and services included in the } \\
\text { basic insurance package (out- } \\
\text { patient primary care, } \\
\text { eyeglasses and dental care } \\
\text { are not covered) }\end{array}$ & $\begin{array}{l}\text { The Irish health system is in transition, both in } \\
\text { terms of policies and in terms of medical } \\
\text { resources (fewer doctors but more students). } \\
\text { Regulations on prices, physician workforce and } \\
\text { hospital management remain more stringent than } \\
\text { in most other countries of this group while market } \\
\text { forces are reinforced }\end{array}$ \\
\hline & $\begin{array}{l}\text { Mixed signals on } \\
\text { output/acute care } \\
\text { efficiency }\end{array}$ & $\begin{array}{l}\text { Less acute care } \\
\text { beds. More nurses } \\
\text { and medical } \\
\text { students }\end{array}$ & $\begin{array}{l}\text { Less hospital } \\
\text { discharges }\end{array}$ & $\begin{array}{l}\text { No full set of } \\
\text { internationally comparable } \\
\text { data to break down } \\
\text { spending by sub-sector }\end{array}$ & $\begin{array}{l}\text { More choice among providers, } \\
\text { less gate-keeping and less } \\
\text { price signals on users }\end{array}$ & \\
\hline & $\begin{array}{l}\text { Mixed scores on quality } \\
\text { of out-patient and } \\
\text { preventive care }\end{array}$ & & & & $\begin{array}{l}\text { Less private provision (in } \\
\text { particular for out-patient care) } \\
\text { and more regulation on } \\
\text { workforce and equipment }\end{array}$ & \\
\hline & $\begin{array}{l}\text { No data on } \\
\text { administrative costs }\end{array}$ & & & & $\begin{array}{l}\text { Less priority setting, more } \\
\text { regulation on prices paid by } \\
\text { third-party payers, no } \\
\text { decentralisation }\end{array}$ & $\begin{array}{l}\text { Better priority setting could help foster efficiency } \\
\text { in resource allocation. Internationally-comparable } \\
\text { data on the allocation of health care spending } \\
\text { across sectors and on administrative costs } \\
\text { should be developed }\end{array}$ \\
\hline \multirow[t]{4}{*}{ Italy } & $\begin{array}{l}\text { High DEA score, low } \\
\text { amenable mortality rate } \\
\text { and low inequalities in } \\
\text { health status }\end{array}$ & & & Higher tax-financed share & & \\
\hline & $\begin{array}{l}\text { Mixed signals on } \\
\text { output/in-patient care } \\
\text { efficiency }\end{array}$ & $\begin{array}{l}\text { More doctors and } \\
\text { medical students; } \\
\text { less nurses }\end{array}$ & $\begin{array}{l}\text { Slightly less } \\
\text { hospital } \\
\text { discharges per } \\
\text { capita }\end{array}$ & Higher in-patient share & $\begin{array}{l}\text { Less private provision (in } \\
\text { particular for specialist } \\
\text { services) and less information } \\
\text { on the quality and prices of } \\
\text { services }\end{array}$ & $\begin{array}{l}\text { Strategies to increase efficiency in the in-patient } \\
\text { care sector should be devised. Options to } \\
\text { consider include: the publication of information } \\
\text { on quality and price of services and the reform of } \\
\text { payment systems for in-patient specialists }\end{array}$ \\
\hline & $\begin{array}{l}\text { Rather high quality of } \\
\text { (out-patient/preventive) } \\
\text { care }\end{array}$ & $\begin{array}{l}\text { Less acute care } \\
\text { beds per capita but } \\
\text { more high-tech } \\
\text { equipment }\end{array}$ & & & $\begin{array}{l}\text { More gate-keeping and more } \\
\text { choice of providers }\end{array}$ & \\
\hline & Low administrative costs & & & & $\begin{array}{l}\text { Low consistency of } \\
\text { responsibility assignment } \\
\text { across government levels. } \\
\text { More regulation of provider } \\
\text { prices and resources }\end{array}$ & $\begin{array}{l}\text { Efforts to increase consistency in the allocation } \\
\text { of resources across government levels could } \\
\text { contribute to raise spending efficiency }\end{array}$ \\
\hline
\end{tabular}


ECO/WKP(2010)25

\begin{tabular}{|c|c|c|c|c|c|c|}
\hline & Efficiency and quality & $\begin{array}{l}\text { Prices and physical } \\
\text { resources }\end{array}$ & $\begin{array}{l}\text { Activity and } \\
\text { consumption }\end{array}$ & $\begin{array}{l}\text { Financing and } \\
\text { spending mix }\end{array}$ & Policies and institutions & $\begin{array}{l}\text { Weaknesses and policy inconsistencies } \\
\text { emerging from the set of indicators }\end{array}$ \\
\hline \multirow[t]{4}{*}{ New Zealand } & $\begin{array}{l}\text { Average DEA score and } \\
\text { lower rate of amenable } \\
\text { mortality but higher } \\
\text { inequalities in health } \\
\text { status }\end{array}$ & $\begin{array}{l}\text { Below average } \\
\text { health care spending } \\
\text { per capita }\end{array}$ & & $\begin{array}{l}\text { Higher public, tax- } \\
\text { financed, share }\end{array}$ & $\begin{array}{l}\text { More reliance on PHI for the } \\
\text { "over-the-basic" segment }\end{array}$ & $\begin{array}{l}\text { Examine the reasons behind high inequalities in } \\
\text { health status }\end{array}$ \\
\hline & $\begin{array}{l}\text { Rather low scores on } \\
\text { the efficiency in the } \\
\text { acute care sector }\end{array}$ & $\begin{array}{l}\text { Less doctors per } \\
\text { capita and less } \\
\text { medical students }\end{array}$ & $\begin{array}{l}\text { Less hospital } \\
\text { discharges per } \\
\text { capita }\end{array}$ & $\begin{array}{l}\text { Rather low out-of-pocket } \\
\text { payment share }\end{array}$ & Less choice among providers & $\begin{array}{l}\text { Examine the reasons behind the rather low } \\
\text { performance of in-patient and out-patient care } \\
\text { sectors. The degree of user choice among } \\
\text { providers and the provider payment systems (in } \\
\text { particular on the best mix between fixed and } \\
\text { activity-based elements) should be examined }\end{array}$ \\
\hline & $\begin{array}{l}\text { Mixed signals on the } \\
\text { quality of (out- } \\
\text { patient/preventive) care }\end{array}$ & $\begin{array}{l}\text { Fewer high-tech } \\
\text { equipment per capita }\end{array}$ & $\begin{array}{l}\text { Less } \\
\text { consultations per } \\
\text { capita }\end{array}$ & $\begin{array}{l}\text { High out-patient share and } \\
\text { low drug share }\end{array}$ & $\begin{array}{l}\text { More information available on } \\
\text { the quality of services }\end{array}$ & $\begin{array}{l}\text { The high share of out-patient expenditure despite } \\
\text { the low number of doctor consultations is striking }\end{array}$ \\
\hline & $\begin{array}{l}\text { Very high administrative } \\
\text { costs }\end{array}$ & $\begin{array}{l}\text { High relative income } \\
\text { level of nurses }\end{array}$ & & & & Examine options to reduce administrative costs \\
\hline \multirow[t]{4}{*}{ Norway } & $\begin{array}{l}\text { High DEA score, lower } \\
\text { amenable mortality rates } \\
\text { and lower inequalities in } \\
\text { health status }\end{array}$ & $\begin{array}{l}\text { Spending per capita } \\
\text { is well above the } \\
\text { OECD average }\end{array}$ & & $\begin{array}{l}\text { High share of public, tax, } \\
\text { financing }\end{array}$ & $\begin{array}{l}\text { Lower scope of basic } \\
\text { insurance coverage (dental } \\
\text { care and eyeglasses are not } \\
\text { covered) }\end{array}$ & $\begin{array}{l}\text { Explore the reasons behind the relatively high } \\
\text { number of hospital discharges and whether the } \\
\text { very high number of doctors and nurses per } \\
\text { capita corresponds to medical needs }\end{array}$ \\
\hline & $\begin{array}{l}\text { High efficiency of } \\
\text { output/in-patient care } \\
\text { sector }\end{array}$ & $\begin{array}{l}\text { Less acute care } \\
\text { beds per capita }\end{array}$ & $\begin{array}{l}\text { More hospital } \\
\text { discharges per } \\
\text { capita }\end{array}$ & High in-patient care share & $\begin{array}{l}\text { Both more choice among } \\
\text { providers and more gate- } \\
\text { keeping }\end{array}$ & \\
\hline & $\begin{array}{l}\text { Mixed signals on the } \\
\text { quality of out-patient and } \\
\text { preventive care }\end{array}$ & $\begin{array}{l}\text { Large number of } \\
\text { doctors per capita } \\
\text { and very large } \\
\text { number of nurses }\end{array}$ & & & $\begin{array}{l}\text { More private provision than } \\
\text { the group average and more } \\
\text { information on the quality of } \\
\text { services }\end{array}$ & \\
\hline & Low administrative costs & $\begin{array}{l}\text { Lower relative } \\
\text { income level of } \\
\text { nurses and } \\
\text { specialists }\end{array}$ & & & $\begin{array}{l}\text { More decentralisation but } \\
\text { higher consistency across } \\
\text { levels of government. Better } \\
\text { priority setting }\end{array}$ & \\
\hline
\end{tabular}




\begin{tabular}{|c|c|c|c|c|c|c|}
\hline & Efficiency and quality & $\begin{array}{l}\text { Prices and physical } \\
\text { resources }\end{array}$ & $\begin{array}{l}\text { Activity and } \\
\text { consumption }\end{array}$ & $\begin{array}{l}\text { Financing and } \\
\text { spending mix }\end{array}$ & Policies and institutions & $\begin{array}{l}\text { Weaknesses and policy inconsistencies } \\
\text { emerging from the set of indicators }\end{array}$ \\
\hline \multirow[t]{4}{*}{ Poland } & $\begin{array}{l}\text { Above average DEA } \\
\text { score but higher } \\
\text { amenable mortality rates } \\
\text { and inequalities in health } \\
\text { status }\end{array}$ & $\begin{array}{l}\text { Low health care } \\
\text { spending per capita } \\
\text { and as a share of } \\
\text { GDP }\end{array}$ & & Low tax-financed share & $\begin{array}{l}\text { Large scope and depth of } \\
\text { basic insurance coverage. } \\
\text { Very limited market } \\
\text { mechanisms in the insurance } \\
\text { market }\end{array}$ & $\begin{array}{l}\text { The Polish system relies on both more market } \\
\text { mechanisms and more regulations to steer the } \\
\text { supply of health care services. The reasons } \\
\text { behind the high inequalities in health status } \\
\text { should also be examined }\end{array}$ \\
\hline & $\begin{array}{l}\text { Lower length of stay in } \\
\text { the acute care sector }\end{array}$ & $\begin{array}{l}\text { More acute care } \\
\text { beds per capita }\end{array}$ & $\begin{array}{l}\text { More hospital } \\
\text { discharges per } \\
\text { capita }\end{array}$ & $\begin{array}{l}\text { High out-of-pocket } \\
\text { payments }\end{array}$ & $\begin{array}{l}\text { More private provision and } \\
\text { volume incentives but also } \\
\text { more regulation on provider } \\
\text { prices and less information on } \\
\text { the quality and prices of } \\
\text { services }\end{array}$ & \\
\hline & $\begin{array}{l}\text { Low quality of out- } \\
\text { patient care as } \\
\text { measured by the } \\
\text { number of avoidable in- } \\
\text { patient admissions }\end{array}$ & $\begin{array}{l}\text { Less doctors, nurses } \\
\text { and medical } \\
\text { students }\end{array}$ & & High drug share & $\begin{array}{l}\text { More choice of providers and } \\
\text { less gate-keeping }\end{array}$ & $\begin{array}{l}\text { Devise strategies to improve the quality of out- } \\
\text { patient care. Combining the existing capitation } \\
\text { system for GPs with some elements of fee-for- } \\
\text { services could be an option }\end{array}$ \\
\hline & Low administrative costs & Low prices & & & $\begin{array}{l}\text { Less regulation on medical } \\
\text { staffing and equipment }\end{array}$ & $\begin{array}{l}\text { Efforts to increase consistency in the allocation } \\
\text { of resources across government levels could } \\
\text { contribute to raise spending efficiency }\end{array}$ \\
\hline \multirow[t]{4}{*}{$\begin{array}{l}\text { United } \\
\text { Kingdom }\end{array}$} & $\begin{array}{l}\text { Below average DEA } \\
\text { score }\end{array}$ & $\begin{array}{l}\text { About average } \\
\text { spending per capita }\end{array}$ & & $\begin{array}{l}\text { High share of tax financed } \\
\text { public spending }\end{array}$ & & $\begin{array}{l}\text { The quantity and quality of health care services } \\
\text { remain lower than the OECD average while } \\
\text { compensation levels are higher. Reinforcing } \\
\text { competitive pressures on providers could help } \\
\text { mitigate price pressures, e.g. by increasing user } \\
\text { choice further and reforming compensation } \\
\text { systems }\end{array}$ \\
\hline & $\begin{array}{l}\text { Mixed scores on output } \\
\text { efficiency in the acute } \\
\text { care sector }\end{array}$ & $\begin{array}{l}\text { Less acute care } \\
\text { beds per capita and } \\
\text { high-tech equipment }\end{array}$ & $\begin{array}{l}\text { Less hospital } \\
\text { discharges per } \\
\text { capita }\end{array}$ & & $\begin{array}{l}\text { More restricted choice among } \\
\text { providers }\end{array}$ & \\
\hline & $\begin{array}{l}\text { Mixed signals on the } \\
\text { quality of (out- } \\
\text { patient/preventive) care }\end{array}$ & $\begin{array}{l}\text { Less doctors per } \\
\text { capita }\end{array}$ & $\begin{array}{l}\text { Less doctor } \\
\text { consultations per } \\
\text { capita }\end{array}$ & & & \\
\hline & $\begin{array}{l}\text { No internationally- } \\
\text { comparable data on } \\
\text { administrative costs }\end{array}$ & $\begin{array}{l}\text { High relative income } \\
\text { level of health } \\
\text { professionals }\end{array}$ & & $\begin{array}{l}\text { Low out-of-pocket } \\
\text { payments }\end{array}$ & $\begin{array}{l}\text { High degree of priority setting } \\
\text { but low consistency in } \\
\text { responsibility assignment } \\
\text { across government bodies }\end{array}$ & $\begin{array}{l}\text { Efforts to increase consistency in the allocation } \\
\text { of responsibility across government bodies could } \\
\text { contribute to raise spending efficiency. Improve } \\
\text { availability of comparable data on the allocation } \\
\text { of spending across sub-sectors }\end{array}$ \\
\hline
\end{tabular}




\section{Bibliography}

Arrow, K. (1963), "Uncertainty and the Welfare Economics of Medical Care", The American Economic Review, Vol. 53, No. 5, pp. 941-973.

Arts, W. and J. Gelissen (2002), "Three Worlds of Welfare Capitalism or More? A State-of-the-Art Report", Journal of European Social Policy, Vol. 12, No. 2.

Bach, S., H. Blöchliger and D. Wallau (2009), "The Spending Power of Sub-central Governments: A Pilot Study”, OECD Economic Department Working Papers, No. 705, OECD, Paris.

Bambra, C. (2007), "Sifting the Wheat from the Chaff: a Two-dimensional Discriminate Analysis of Welfare State Regime Theory", Social Policy and Administration, Vol. 41, No. 1, February, www3.interscience.wiley.com/cgi-bin/fulltext/118503771/PDFSTART.

Bassanini, A. and R. Duval (2009), "Unemployment, Institutions, and Reform Complementarities: Re-assessing the Aggregate Evidence for OECD Countries", Oxford Review of Economic Policy, Vol. 25, No. 1.

Berger, M. and J. Messer (2002), "Public Financing of Health Expenditure, Insurance, and Health Outcomes", Applied Economics, Vol. 34, No. 17, pp. 2105-2113.

Braga de Macedo J., J. Oliveira Martins and B. Rocha (2009), "Growth and Policy Complementarities: Are Complementary Reforms a "Luxury" for Developing Countries?", paper presented at IZA-FRDB Workshop on "Tracking Structural Reforms", University Bocconi, Milan, March.

Burau, V. and R.H. Blank (2006), "Comparing Health Policy: An Assessment of Typologies of Health Systems", Journal of Comparative Policy Analysis, Vol. 8, No. 1, March, pp. 63-76.

Busse, R., J. Schreyögg and P.C. Smith (2008), "Variability in Healthcare Treatment Costs amongst Nine EU Countries - Results from the HealthBasket Project", Health Economics, Vol. 17 (special Issue: Analysing the variation of health care treatment costs in Europe).

Busse, R., J. Schreyögg and P.C. Smith (2006), "Hospital Case Payment Systems in Europe", Health Care Management Science, Vol. 9, pp. 211-213.

Colombo, F. and N. Tapay (2004), "Private Health Insurance in OECD Countries: the Benefits and Costs for Individuals and Health Systems", OECD Health Working Papers, No. 15, OECD, Paris, http://oberon.sourceoecd.org/vl=2446023/cl=15/nw=1/rpsv/cgi-bin $/$ wppdf?file $=5 l g s j h v j 74 f 5 . p d f$

Crombie, I. K. and H.T.O. Davies (1998), "Beyond Health Outcomes: the Advantages of Measuring Process", Journal of Evaluation and Clinical Practice, Vol. 4, Issue 1, pp. 31-38.

Cutler, D.M. (2002), "Equality, Efficiency and Market Fundamentals: the Dynamics of International Medical-care Reform", Journal of Economic Literature, Vol. 40, Issue 3, pp. 881-906.

Delattre, E. and B. Dormont (2003), "Fixed Fees and Physician-induced Demand: a Panel Data Study on French Physicians", Health Economics, Vol. 12, pp. 741-754. 
De Looper, M. and G. Lafortune (2009), "Measuring Disparities in Health Status and in Access and Use of Health Care in OECD Countries", OECD Health Working Papers, No. 43, Directorate for Employment, Labour and Social Affairs, OECD, Paris.

Diderichsen, F. (1995), "Market Reforms in Health Care and Sustainability of the Welfare State: Lessons from Sweden", Health Policy, Vol. 21, pp. 141-153.

Docteur, E. and H. Oxley (2003), "Health-Care Systems: Lessons from Reform Experience", OECD Health Working Papers, No. 9, Directorate for Employment, Labour and Social Affairs, OECD, Paris.

Dormont, B., J. Oliveira Martins, F. Pelgrin and M. Suhrcke (2007), "Health Expenditures, Longevity and Growth", paper presented at the IX European Conference of the Fondazione Rodolfo Debenedetti on "Health, Longevity and Productivity", May 2007.

Edwards, R.D. and S. Tuljapurkar (2005), "Inequality in Life Spans and a New Perspective on Mortality Convergence Across Industrialized Countries", Population and Development Review, Vol. 31, No. 4, December.

Eggleston, K. (2009), “Provider Payment Incentives: International Comparisons ”, International Journal of Health Care Finance and Economics, Vol. 9, No. 2.

Elola, J., A. Daponte and V. Navarro (1995), "Health Indicators and the Organisation of Health Care Systems in Western Europe", American Journal of Public Health, Vol. 85, No. 10, pp. 1397-1401, www.pubmedcentral.nih.gov/picrender.fcgi? artid $=1615621 \&$ blobtype $=p d f$.

Ennis, S. (2006), "Competition in the Provision of Hospital Services", Journal of Competition Law and Policy, Vol. 8, No. 3.

Erlandsen, E. (2007), "Improving the Efficiency of Health Care Spending: Selected Evidence on Hospital Performance", OECD Economics Department Working Papers, No. 555, OECD, Paris.

Evans, D.B. (2002), "The Evolution of WHO's Approach to Health System Performance Assessment", in Measuring Up: Improving Health System Performance in OECD Countries, Chapter 9, OECD, Paris.

Filmer, D. and L. Pritchett (1997), "Child Mortality and Public Spending on Health: How Much Does Money Matter?", www.worldbank.org/html/dec/Publications/Workpapers/WPS1800series/ wps1864/wps1864.pdf.

Frank, R. (2004), "Behavioural Economics and Health Economics", NBER Working Paper, No. 10881, October 2004.

Fujisawa, R. and G. Lafortune (2008), "The Remuneration of General Practitioners and Specialists in 14 OECD Countries: What Are the Factors Explaining Variations across Countries?", OECD Health Working Papers, No. 32, Directorate for Employment, Labour and Social Affairs, OECD.

Garcia Armesto S., M.L. Gil Lapetra, L. Wei, E. Kelley and the Members of the HCQI Expert Group (2007), "Health Care Quality Indicators Project - 2006 Data Collection Update Report", OECD Health Working Paper, No. 29. 
Gonand, F., I. Joumard and R. Price (2007), "Public Spending Efficiency: Institutional Indicators in Primary and Secondary Education", OECD Economics Department Working Papers, No. 543, OECD, Paris.

Grignon, M., V. Paris and D. Polton (2002), "Influence of Physician Payment Methods on the Efficiency of the Health Care System", Commission on the Future of Health Care in Canada, Discussion Paper, No. 35 .

Grytten, J., F. Carlsen and I. Skau (2008), "Primary Physicians' Response to Changes in Fees", European Journal of Health Economics, Vol. 9, No. 2.

Häkkinen, U. and I. Joumard (2007), "Cross-Country Analysis of Efficiency in OECD Health Care Sectors: Options for Research", OECD Economics Department Working Papers, No. 554, OECD, Paris.

Hanoch, Y., T. Rice, J. Cummings and S. Wood (2009), "How Much Choice is Too Much? The Case of Medicare Prescription Drug Benefit", Health Services Research, Vol. 44, Issue 4, August.

Hofmarcher, M.M, H. Oxley and E. Rusticelli (2007), "Improved Health System Performance through Better Care Coordination", OECD Health Working Paper, No. 30.

Hollingsworth, B. (2007), "State of the Art: Efficiency Measurement in Health and Health Care: Non Parametric Efficiency Measurement", iHEA 2007 6th World Congress: Explorations in Health Economics Paper http://papers.ssrn.com/sol3/papers.cfm?abstract_id=992983\#PaperDownload

Hsiao, W.C. and P.S. Heller (2007), "What Should Macroeconomists Know about Health Care Policy?", IMF Working Paper, WP/07/13, www.imf.org/external/pubs/ft/wp/2007/wp0713.pdf.

Hurley, J. (2000), "An Overview of the Normative Economics of the Health Sector" in A. J. Culyer and J. P. Newhouse (eds.), Handbook of Health Economics, Elsevier, Vo1. 1, Part 1, pp. 55-118.

Hurst, J. (2002), "Performance Measurement and Improvement in OECD Health Systems: Overview of Issues and Challenges", in Measuring Up: Improving Health System Performance in OECD Countries, Chapter 2, OECD, Paris.

Hussey, P.S., H. de Vries, J. Romely, M.C. Wang, S.S. Chen, P.G. Shekelle and E. A. McGlynn (2009), “A Systematic Review of Health Care Efficiency Measures", Health Services Research, Vol. 44, Issue 3, June 2009, http://www3.interscience.wiley.com/cgi-bin/fulltext/121671514/PDFSTART

Jacobs, R., P.C. Smith and A. Street (2006), "Measuring Efficiency in Health Care - Analytic Techniques and Health Policy", Cambridge University Press.

Jacobzone, S., P. Moise and L. Moon (2002), "Opening the Black Box: What Can Be Learned from a Disease-Based Approach?”, in Measuring up - Improving Health System Performance in OECD Countries, OECD, Paris.

Joumard, I. and P. Kongsrud (2003), "Fiscal Relations Across Government Levels", OECD Economics Department Working Papers, No. 375, OECD, Paris.

Joumard, I., C. André, C. Nicq and O. Chatal (2008), "Health Status Determinants: Lifestyle, Environment, Health Care Resources and Efficiency", OECD Economics Department Working Papers, No. 627, OECD, Paris. 
Kainzinger, F., C.A. Raible, K. Pietrek, J. Müller-Nordhorn and S.N. Willich (2009), "Optimization of Hospital Stay through Length-of-Stay-Oriented Case Management: an Empirical Study", Journal of Public Health, Vol. 17, pp. 395-400.

Kelley, E. and J. Hurst (2006), "Health Care Quality Indicators Project - Conceptual Paper", OECD Health Working Paper, No. 23, OECD, Paris.

Kelley, E., S. Garcia Armesto, M.L. Gil Lapetra, L. Wei and the Members of the HCQI group (2007), "Health Care Quality Indicators Project - 2006 Data Collection Update Report", OECD Health Working Paper, No. 27.

Kotzian, P. (2006), "Control and Performance of Health Care Systems - a Comparative Analysis of 19 OECD Countries", Working Paper, No. 6, Technische Universität Darmstadt, www.politikwissenschaft.tu-darmstadt.de/fileadmin/pg/media/working-paper/2006/TUDIfP_Working-Paper_2006-06_Kotzian.pdf.

Kotzian, P. (2007), Delegation and Control in Health Care Systems, Delegation and Control in 22 OECD Health Care Systems, A Data Handbook, Vol. 1, Technical University of Darmstadt, June.

Leu, R.E. and P. Matter (2009) “Comparaison des systèmes de santé suisse et néerlandais”, La Vie économique, 11-2009.

Manning, W.G. et al. (1988), "Health Insurance and the Demand for Medical Care - Evidence from a Randomized Experiment”, Rand Insurance Experiment Series, www.rand.org/pubs/reports/2005/R3476.pdf

Mattke S., E. Kelley, P. Scherer, J. Hurst, M. L. Gil Lapetra, and the HCQI Expert Group Members (2006), "Health Care Quality Indicators Project - Initial Indicators Report", OECD Health Working Paper, No. 22.

Medved, J., J. Nemec and L. Vítek (2005), "Social Health Insurance and its Failure in the Czech Republic and Slovakia: The Role of the State", Prague Economic Papers, 1.

Nixon, J. (2000), "How Does the UK NHS Compare with European Standards? A Review of EU Health Care Systems Using Hierarchical Cluster Analysis", Discussion Paper, 182, Centre for Health Economics, University of York, www.york.ac.uk/inst/che/pdf/DP182.pdf

Nolte, E. and C.M. McKee (2008), "Measuring the Health of Nations: Updating an Earlier Analysis", Health Affairs, Vol. 27, No. 1, pp. 58-71.

OECD (2002), OECD Economic Surveys: Norway, OECD, Paris.

OECD (2003), OECD Reviews of Health Care Systems - Korea, OECD, Paris.

OECD (2004), Towards High-Performing Health Systems, OECD, Paris.

OECD (2005a), "Handbook on Constructing Composite Indicators: Methodology and User Guide", OECD Statistics Working Paper, OECD, Paris.

OECD (2005b), OECD Economic Surveys: Belgium, OECD, Paris.

OECD (2005c), OECD Economic Surveys: Sweden, OECD, Paris. 
OECD (2006a), OECD Economic Surveys: Australia, OECD, Paris.

OECD (2006b), OECD Journal of Competition Law and Policy, Vol. 8, No. 3, OECD, Paris.

OECD (2006c), Society at a Glance, OECD, Paris.

OECD (2006d), OECD Employment Outlook: Boosting Jobs and Incomes, OECD, Paris.

OECD (2008), OECD Reviews of Health Systems - Turkey, OECD, Paris.

OECD (2009a), OECD Health at a Glance, OECD, Paris.

OECD (2009b), OECD Economic Surveys: Japan, OECD, Paris.

OECD (2009c), OECD Economic Surveys: United Kingdom, OECD, Paris.

Oliveira Martins, J. and C. de la Maisonneuve (2006), "The Drivers of Public Expenditure on Health and Long-Term Care: an Integrated Approach", OECD Economic Studies No. 43/2, OECD, Paris.

Or, Z. (2000a), "Determinants of Health Outcomes in Industrialised Countries: a Pooled, Cross-country, Time Series Analysis", OECD Economic Studies, No. 30, 2000/I.

Paris, V., M. Devaux and L. Wei (2010), "Health System Institutional Characteristics: a Survey of 29 OECD Countries", OECD Health Working Paper, No. 50, forthcoming.

Pommer, E., A. van Torre and B. Kuhry (2004), "Health Care", in Public Sector Performance, Social and Cultural Planning Office of the Netherlands.

RIVM (2008), Dutch Health Care Performance Report, www.rivm.nl/vtv/object_binary/ o6118_Dutch\%20Healthcare\%20Performance\%20Report\%202008.pdf

Sabik, L.M. and R.K. Lie (2008), "Priority Setting in Health Care: Lessons from the Experiences of Eight Countries", International Journal for Equity in Health, 7:4.

Saisana, M. and S. Tarantola (2002), "State-of-the-art Report on Current Methodologies and Practices for Composite Indicator Development", European Commission Joint Research Centre and Institute for the Protection and Security of the Citizen, Italy.

Saltman, R. B. (2008), "Decentralization, Re-centralization and Future European Health Policy", European Journal of Public Health, Vol. 18, No. 2.

Schreyer, P., A. Gallais, S. Hopkins, F. Koechlin, L. Lorenzoni and S. Varjonen (2010), “Towards Measuring the Volume Output of Education and Health Services", OECD Statistics Directorate Working Papers, No. 33, OECD, Paris.

Shafrin, J. (2009), “Operating on Commission: Analyzing How Physician Financial Incentives Affect Surgery Rates", Health Economics, forthcoming.

Shakarishvili, G. (2009), "Building on Health Systems Frameworks for Developing a Common Approach to Health Systems Strengthening", Draft for discussion prepared for the technical workshop on Health Systems Strengthening, Washington DC, 25-27 June 2009. 
Simoens, S. and J. Hurst (2006), “The Supply of Physician Services in OECD Countries”, OECD Health Working Paper, No. 21, OECD, Paris.

Smith, P. (2002), "Developing Composite Indicators for Assessing Health Care Efficiency" in Measuring Up: Improving Health System Performance in OECD Countries, Chapter 14, OECD, Paris.

Smith, P.C. (2008a), "Market Mechanisms and the Use of Health Care Resources", in Achieving Better Value for money in Health Care, OECD Health Policy Studies, OECD, Paris.

Smith, P.C. (2008b), "The Impact of User Charges on Health Care”, in Achieving Better Value for Money in Health Care, OECD Health Policy Studies, OECD, Paris.

Stargardt, T. (2008), "Health Service Costs in Europe: Costs and Reimbursement of Primary Hip Replacement in Nine Countries", Health Economics, Vol. 17 (Special Issue: Analysing the variation of health care treatment costs in Europe).

Steinmann, L., G. Dittrich, A. Karmann and P. Zweifel (2004), "Measuring and Comparing the (In)efficiency of German and Swiss Hospitals", European Journal of Health Economics, Vol. 5, No. 3, pp. 216-226.

Sutherland, D., R. Price, I. Joumard and C. Nicq (2007), "Performance Indicators for Spending Efficiency in Primary and Secondary Education", OECD Economics Department Working Papers, No. 546, OECD, Paris.

Suzuki, R. and H. Shimodaira (2006), "Pvclust: an R Package for Assessing the Uncertainty in Hierarchical Clustering”, Bioinformatics, Vol. 22, No. 12, pp. 1540-1542, Oxford University Press.

Tobias, M. and L.C. Yeh (2009), "How Much Does Health Care Contribute to Health Gain and to Health Inequality? Trends in Amenable Mortality in New Zealand 1981-2004", Australian and New Zealand Journal of Public Health, Vol. 33, Issue 1.

Wagstaff, A. (2009), "Social Health Insurance Versus Tax-financed Health Systems - Evidence from the OECD”, World Bank Policy Research Working Paper, No. 4821.

Wendt, C. (2009), "Mapping European Healthcare Systems: a Comparative Analysis of Financing, Service Provision and Access to Healthcare", Journal of European Social Policy, Vol. 19, No. 5, December.

Wendt, C., L. Frisina and H. Rothgang (2009), "Healthcare System Types: A Conceptual Framework for Comparison", Social Policy and Administration, Vol. 43, No. 1, February.

Woolhandler, S., T. Campbell and D. Himmelstein (2003), "Costs of Health Care Administration in the United States and Canada", The New England Journal of Medicine, Vol. 349, August.

World Health Organisation (2000), The World Health Report 2000 - Health Systems: Improving Performance, WHO, Geneva.

World Health Organisation (2007), "Everybody's Business - Strengthening Health Systems to Improve Health Outcomes", WHO's Framework for Action, WHO, Geneva.

World Health Organisation (2009), "Health Systems, Health and Wealth", WHO European Ministerial Conference on Health Systems, 25-27 June 2008, Tallinn, Estonia. 
ECO/WKP(2010)25

\section{Annex 1. \\ The World Health Organisation study on the effectiveness of health care systems}

In 2000, the World Health Organisation undertook a major effort to measure whether health systems in WHO member states achieve various goals and how efficiently they are using their resources (Murray and Evans, 2003; WHO, 2000). The main features of this work are as follows:

Two outcome measures for the health care system were built for 191 countries:

- The average health status of the population was measured by a simple indicator, the DisabilityAdjusted Life Expectancy (DALE). DALE aims at measuring the life expectancy of the population taking into account a "qualitative" deterioration in life caused by disabilities due to illness, injuries and/or accidents.

- A composite index made up of five components: the average level of health status (measured by the country's DALE overall); inequities in health status (measured by the dispersion in child survival rates); average degree of responsiveness of the health care system (measured by a composite index made up of various sub-indicators for the respect of dignity, confidentiality, choice of provider, etc.); inequities in responsiveness; and fairness of financial contribution. The five goals were aggregated on the basis of weights derived from a survey of 1006 persons. Approximately half of the respondents were WHO's own staff while the other half consisted of people who had visited the WHO web site.

\section{The "efficient frontier approach" was used for measuring country effectiveness}

Individual countries' effectiveness scores were derived with inputs measured in financial terms (health care spending per capita converted with economy-wide PPP exchange rates). The average years of schooling for the population aged over 25 was considered as another important input to be accounted for in estimating the production function. Stochastic frontier methods (as opposed to deterministic frontier approaches such as with data envelopment analysis) were used since random unobserved factors and measurement problems were perceived to be important. Countries were then ranked according to their effectiveness.

\section{The philosophy and methodology of the WHO's work have led to considerable discussion}

The WHO methodology has raised various concerns. The use of composite indicators for assessing health care system performance has been criticised on several grounds. First, by aggregating measures of various aspects of performance, a composite indicator may disguise serious failings in certain parts of the health care system. Second, it may make it difficult to identify factors responsible for poor performance and therefore what remedial action to take. Third, the methodology used to derive the weighting system for the sub-indicators is questionable. Fourth, the weights used in composite indicators reflect a single set of preferences. Differences in countries' policy priorities may be important. 
In addition, it was felt that the determinants of health-system performance were too complex to be captured within a traceable statistical model, particularly in view of the poor quality of the data. The production function used was also criticised for not recognising the important time lags that exist in producing health outcomes (See Anand et al., 2003 for more detail).

WHO researchers responded to many of these criticisms (Murray and Evans, 2003). The Scientific Peer Review Group (Anand et al., 2003) suggested that there was a case for continuing the WHO work in the efficiency area, but as an ongoing research programme rather than providing a definitive judgment on health systems and country rankings. They also proposed some new analysis including a second-stage analysis (Evans et al., 2003), which explores whether exogenous factors, such as institutional quality, income distribution, population density, etc., have an impact on effectiveness. The WHO activity on benchmarking health system effectiveness had however come to a standstill for several years. In 2008, the WHO European Ministerial Conference on Health Systems decided to develop tools to improve performance assessment of health care systems - the Tallin Charter (WHO, 2009). 
Annex 2.

Additional information on health care outcomes, spending and efficiency 
Table A2.1. Measures of health status and country rankings

2007 or latest year available $^{1}$

Panel A. Levels

\begin{tabular}{|c|c|c|c|c|c|c|c|c|c|c|c|c|c|c|c|c|}
\hline & \multicolumn{3}{|c|}{ Life expectancy at birth } & \multicolumn{2}{|c|}{ Life expectancy at 65} & \multicolumn{3}{|c|}{$\begin{array}{c}\text { Potential years of life lost (PYLL) } \\
\text { adjusted }^{2}\end{array}$} & \multirow[t]{2}{*}{\begin{tabular}{|l} 
Perinatal \\
mortality
\end{tabular}} & \multirow[t]{2}{*}{$\begin{array}{c}\text { Infant } \\
\text { mortality }\end{array}$} & \multicolumn{3}{|c|}{ Health-adjusted life expectancy } & \multicolumn{2}{|c|}{$\begin{array}{l}\text { Health-adjusted life } \\
\text { expectancy (HALE) } \\
\text { at } 60\end{array}$} & \multirow[t]{2}{*}{$\begin{array}{c}\text { Amenable } \\
\text { mortality }\end{array}$} \\
\hline & $\begin{array}{l}\text { Total } \\
\end{array}$ & Females & Males & Females & Males & Total & Females & Males & & & Females & Males & Total & Females & Males & \\
\hline & \multicolumn{3}{|c|}{ Years } & \multicolumn{2}{|c|}{ Years } & \multicolumn{3}{|c|}{ per 100000 persons aged $0-69$} & \multicolumn{2}{|c|}{ per 1000 births } & \multicolumn{3}{|c|}{ Years } & \multicolumn{2}{|c|}{ Years } & per 100000 persons \\
\hline Australia & 81.4 & 83.7 & 79.0 & 21.6 & 18.5 & 2531 & 2007 & 3051 & 3.6 & 4.2 & 74.3 & 70.9 & 72.6 & 19.5 & 16.9 & 59.2 \\
\hline Austria & 80.1 & 82.9 & 77.3 & 20.8 & 17.4 & 2500 & 1832 & 3181 & 5.9 & 3.7 & 73.5 & 69.3 & 71.4 & 19.3 & 16.2 & 59.8 \\
\hline Belgium & 79.8 & 82.6 & 77.1 & 21.0 & 17.3 & & & & 5.9 & 4.0 & 73.3 & 68.9 & 71.1 & 19.1 & 15.7 & \\
\hline Canada & 80.7 & 83.0 & 78.4 & 21.4 & 18.2 & 2710 & 2228 & 3194 & 6.3 & 5.0 & 74.0 & 70.1 & 72.0 & 19.3 & 16.1 & 64.1 \\
\hline Czech Republic & 77.0 & 80.2 & 73.8 & 18.5 & 15.1 & 3262 & 2163 & 4385 & 4.0 & 3.1 & 70.9 & 65.9 & 68.4 & 16.8 & 13.5 & 106.3 \\
\hline Denmark & 78.4 & 80.6 & 76.2 & 19.2 & 16.5 & 2974 & 2260 & 3680 & 7.6 & 4.0 & 71.1 & 68.6 & 69.8 & 17.2 & 15.2 & 74.3 \\
\hline Finland & 79.5 & 83.1 & 76.0 & 21.3 & 17.0 & 2857 & 1834 & 3871 & 4.1 & 2.7 & 73.5 & 68.7 & 71.1 & 18.9 & 15.7 & 66.9 \\
\hline France & 81.0 & 84.4 & 77.5 & 22.3 & 18.0 & 2824 & 1963 & 3708 & 11.2 & 3.8 & 74.7 & 69.3 & 72.0 & 20.3 & 16.5 & 50.4 \\
\hline Germany & 80.0 & 82.7 & 77.4 & 20.7 & 17.4 & 2689 & 2001 & 3372 & 5.5 & 3.9 & 74.0 & 69.6 & 71.8 & 19.0 & 15.9 & 69.7 \\
\hline Greece & 79.5 & 82.0 & 77.0 & 19.6 & 17.4 & 2644 & 1762 & 3531 & 3.9 & 3.6 & 72.9 & 69.1 & 71.0 & 18.1 & 16.0 & 67.7 \\
\hline Hungary & 73.3 & 77.3 & 69.2 & 17.3 & 13.4 & 5611 & 3641 & 8358 & 7.8 & 5.9 & 68.2 & 61.5 & 64.9 & 15.9 & 12.2 & 167.2 \\
\hline Iceland & 81.2 & 82.9 & 79.4 & 20.6 & 18.3 & 1943 & 1498 & 2262 & 2.6 & 2.0 & 73.6 & 72.1 & 72.8 & 18.7 & 17.5 & 52.8 \\
\hline Ireland & 79.7 & 82.1 & 77.4 & 20.1 & 17.1 & 2585 & 2061 & 3099 & 6.2 & 3.1 & 71.5 & 68.1 & 69.8 & 17.5 & 14.8 & 69.8 \\
\hline Italy & 81.4 & 84.2 & 78.5 & 21.8 & 17.9 & 2261 & 1688 & 2841 & 5.2 & 3.7 & 74.7 & 70.7 & 72.7 & 19.4 & 16.4 & 56.2 \\
\hline Japan & 82.6 & 86.0 & 79.2 & 23.6 & 18.6 & 1998 & 1494 & 2505 & 3.0 & 2.6 & 77.7 & 72.3 & 75.0 & 21.7 & 17.5 & 56.5 \\
\hline Korea & 79.4 & 82.7 & 76.1 & 20.5 & 16.3 & 2644 & 1764 & 3530 & 3.6 & 4.1 & 70.8 & 64.8 & 67.8 & 17.1 & 13.2 & 74.5 \\
\hline Luxembourg & 79.4 & 82.2 & 76.7 & 20.3 & 16.4 & 2487 & 1861 & 3102 & 4.4 & 1.8 & 73.7 & 69.3 & 71.5 & 19.2 & 16.0 & 63.9 \\
\hline Mexico & 75.0 & 77.4 & 72.6 & 18.2 & 16.8 & 5760 & 4683 & 6873 & 16.3 & 15.7 & 67.6 & 63.4 & 65.5 & 16.3 & 14.5 & 121.9 \\
\hline Netherlands & 80.2 & 82.3 & 78.0 & 20.5 & 17.0 & 2398 & 2060 & 2729 & 5.7 & 4.1 & 72.6 & 69.7 & 71.2 & 18.4 & 15.5 & 59.1 \\
\hline New Zealand & 80.2 & 82.2 & 78.2 & 20.7 & 18.1 & 2737 & 2257 & 3224 & 5.7 & 4.8 & 72.2 & 69.5 & 70.8 & 18.2 & 16.0 & 73.1 \\
\hline Norway & 80.6 & 82.9 & 78.3 & 20.8 & 17.5 & 2398 & 1852 & 2929 & 5.7 & 3.1 & 73.6 & 70.4 & 72.0 & 18.9 & 16.2 & 59.8 \\
\hline Poland & 75.4 & 79.7 & 71.0 & 18.9 & 14.6 & 4744 & 2939 & 6653 & 6.7 & 6.0 & 68.5 & 63.1 & 65.8 & 16.1 & 12.8 & 117.7 \\
\hline Portugal & 79.1 & 82.2 & 75.9 & 20.2 & 16.8 & 3634 & 2520 & 4808 & 4.4 & 3.4 & 71.7 & 66.7 & 69.2 & 17.7 & 14.9 & 92.3 \\
\hline Slovak Republic & 74.3 & 78.1 & 70.5 & 17.1 & 13.4 & 4746 & 3057 & 6550 & 6.1 & 6.1 & 69.4 & 63.0 & 66.2 & 16.1 & 12.3 & 160.2 \\
\hline Spain & 81.0 & 84.3 & 77.8 & 22.0 & 17.8 & 2682 & 1793 & 3579 & 4.9 & 3.7 & 75.3 & 69.9 & 72.6 & 19.9 & 16.4 & 60.6 \\
\hline Sweden & 81.0 & 83.0 & 78.9 & 20.7 & 17.8 & 2129 & 1703 & 2543 & 4.3 & 2.5 & 74.8 & 71.9 & 73.3 & 19.6 & 17.1 & 58.2 \\
\hline Switzerland & 81.9 & 84.4 & 79.5 & 22.2 & 18.6 & 2276 & 1814 & 2736 & 6.6 & 3.9 & 75.3 & 71.1 & 73.2 & 20.4 & 17.1 &.. \\
\hline Turkey & 73.4 & 75.6 & 71.1 & 15.8 & 13.9 & & & & 24.0 & 20.7 & 62.8 & 61.2 & 62.0 & 14.2 & 12.8 & .. \\
\hline United Kingdom & 79.5 & 81.7 & 77.3 & 20.1 & 17.4 & 3010 & 2405 & 3621 & 7.7 & 4.8 & 72.1 & 69.1 & 70.6 & 18.1 & 15.7 & 74.0 \\
\hline United States & 78.1 & 80.7 & 75.4 & 20.3 & 17.4 & 3924 & 3128 & 4731 & 6.6 & 6.7 & 71.3 & 67.2 & 69.3 & 17.9 & 15.3 & 88.6 \\
\hline Average & 79.1 & 81.9 & 76.4 & 20.3 & 16.9 & 3034 & 2224 & 3880 & 6.5 & 4.9 & 72.3 & 68.2 & 70.2 & 18.3 & 15.4 & 78.7 \\
\hline Maximum/Minimum & 1.13 & 1.14 & 1.15 & 1.49 & 1.39 & 2.96 & 3.13 & 3.69 & 9.23 & 11.50 & 1.24 & 1.18 & 1.21 & 1.53 & 1.43 & 3.32 \\
\hline Coefficient of variation & 0.03 & 0.03 & 0.04 & 0.08 & 0.09 & 0.34 & 0.32 & 0.39 & 0.65 & 0.79 & 0.04 & 0.05 & 0.04 & 0.09 & 0.10 & 0.39 \\
\hline
\end{tabular}

Coefficient of variation 0.09

(the United Kingdom and the United States. Potential years of life lost adjusted: 2003 for Portugal; 2004 for Austria and Canada; 2005 for Hungary, Luxenbo Spain and the United States; 2006 for Denmark, France, Germany, Italy, Korea, Mexico, Norway, Poland, Sweden and Switzerland. Perinatal mortality: 2005 for Australia, Belgium, Denmark, Ireland, New Zealand, Spain and the United Luxembourg, New Zealand, the Slovak Republic, Spain and the United States; 2006 for Denmark, France, Germany, Italy, Korea, Mexico, Norway, Poland and Sweden.
Lutrat

2. Potential years of life lost (PYLL) are calculated excluding deaths from land transport accidents, accidental falls, suicides and assaults. PYLL data are missing for Belgium and Turkey.

(i.e. France). 
ECO/WKP(2010)25

Table A2.1. Measures of health status and country rankings (cont.)

2007 or latest year available

Panel B. Rankings

\begin{tabular}{|c|c|c|c|c|c|c|c|c|c|c|c|c|c|c|c|c|}
\hline & \multicolumn{3}{|c|}{ Life expectancy at birth } & \multicolumn{2}{|c|}{ Life expectancy at 65} & \multicolumn{3}{|c|}{$\begin{array}{l}\text { Potential years of life lost (PYLL) } \\
\text { adjusted }^{2}\end{array}$} & \multirow[t]{2}{*}{$\begin{array}{l}\text { Perinatal } \\
\text { mortality }^{3}\end{array}$} & \multirow[t]{2}{*}{$\begin{array}{c}\text { Infant } \\
\text { mortality }\end{array}$} & \multicolumn{3}{|c|}{$\begin{array}{l}\text { Health-adjusted life expectancy } \\
\begin{array}{l}\text { (HALE) } \\
\text { at birth }\end{array}\end{array}$} & \multicolumn{2}{|c|}{\begin{tabular}{|c|} 
Health-adjusted life \\
expectancy (HALE) at \\
60
\end{tabular}} & \multirow[t]{2}{*}{$\begin{array}{c}\text { Amenable } \\
\text { mortality }\end{array}$} \\
\hline & Total & Females & Males & Females & Males & Total & Females & Males & & & Females & Males & Total & Female: & Males & \\
\hline & \multicolumn{3}{|c|}{ Years } & \multicolumn{2}{|c|}{ Years } & \multicolumn{3}{|c|}{ per 100000 persons aged $0-69$} & \multicolumn{2}{|c|}{ per 1000 births } & \multicolumn{3}{|c|}{ Years } & \multicolumn{2}{|c|}{ Years } & per 100000 persons \\
\hline Australia & 3 & 6 & 4 & 6 & 3 & 10 & 15 & 8 & 3 & 21 & 7 & 5 & 6 & 6 & 5 & 7 \\
\hline Austria & 13 & 10 & 15 & 10 & 12 & 9 & 9 & 11 & 17 & 11 & 13 & 13 & 13 & 8 & 9 & 8 \\
\hline Belgium & 15 & 15 & 17 & 9 & 17 & & .. & .. & 17 & 17 & 15 & 18 & 15 & 11 & 16 & \\
\hline Canada & 9 & 8 & 7 & 7 & 5 & 16 & 19 & 12 & 21 & 24 & 8 & 8 & 8 & 8 & 11 & 12 \\
\hline Czech Republic & 25 & 25 & 25 & 26 & 26 & 22 & 18 & 22 & 6 & 6 & 24 & 24 & 24 & 25 & 25 & 23 \\
\hline Denmark & 23 & 24 & 20 & 24 & 23 & 20 & 21 & 19 & 25 & 17 & 23 & 20 & 20 & 23 & 21 & 19 \\
\hline Finland & 17 & 7 & 22 & 8 & 19 & 19 & 10 & 21 & 7 & 5 & 13 & 19 & 15 & 13 & 16 & 13 \\
\hline France & 6 & 2 & 12 & 2 & 7 & 18 & 13 & 20 & 28 & 14 & 5 & 13 & 8 & 3 & 6 & 1 \\
\hline Germany & 14 & 13 & 13 & 12 & 12 & 15 & 14 & 14 & 13 & 15 & 8 & 11 & 11 & 12 & 15 & 15 \\
\hline Greece & 17 & 21 & 18 & 23 & 12 & 12 & 5 & 16 & 5 & 10 & 16 & 16 & 17 & 18 & 12 & 14 \\
\hline Hungary & 30 & 29 & 30 & 28 & 29 & 27 & 27 & 28 & 27 & 25 & 28 & 29 & 29 & 29 & 30 & 27 \\
\hline Iceland & 5 & 10 & 2 & 15 & 4 & 1 & 2 & 1 & 1 & 2 & 11 & 2 & 4 & 15 & 1 & 2 \\
\hline Ireland & 16 & 20 & 13 & 21 & 18 & 11 & 17 & 9 & 20 & 6 & 21 & 21 & 20 & 22 & 23 & 16 \\
\hline Italy & 3 & 5 & 6 & 5 & 8 & 4 & 3 & 6 & 12 & 11 & 5 & 6 & 5 & 7 & 7 & 3 \\
\hline Japan & 1 & 1 & 3 & 1 & 1 & 2 & 1 & 2 & 2 & 4 & 1 & 1 & 1 & 1 & 1 & 4 \\
\hline Korea & 20 & 13 & 21 & 16 & 25 & 12 & 6 & 15 & 3 & 19 & 25 & 25 & 25 & 24 & 26 & 20 \\
\hline Luxembourg & 20 & 17 & 19 & 18 & 24 & 8 & 12 & 10 & 9 & 1 & 10 & 13 & 12 & 10 & 12 & 11 \\
\hline Mexico & 27 & 28 & 26 & 27 & 21 & 28 & 28 & 27 & 29 & 29 & 29 & 26 & 28 & 26 & 24 & 25 \\
\hline Netherlands & 11 & 16 & 10 & 16 & 19 & 6 & 16 & 4 & 14 & 19 & 17 & 10 & 14 & 16 & 19 & 6 \\
\hline New Zealand & 11 & 17 & 9 & 12 & 6 & 17 & 20 & 13 & 14 & 22 & 18 & 12 & 18 & 17 & 12 & 17 \\
\hline Norway & 10 & 10 & 8 & 10 & 11 & 6 & 11 & 7 & 14 & 6 & 11 & 7 & 8 & 13 & 9 & 9 \\
\hline Poland & 26 & 26 & 28 & 25 & 27 & 25 & 24 & 26 & 24 & 26 & 27 & 27 & 27 & 27 & 27 & 24 \\
\hline Portugal & 22 & 17 & 23 & 20 & 21 & 23 & 23 & 24 & 9 & 9 & 20 & 23 & 23 & 21 & 22 & 22 \\
\hline Slovak Republic & 28 & 27 & 29 & 29 & 29 & 26 & 25 & 25 & 19 & 27 & 26 & 28 & 26 & 27 & 29 & 26 \\
\hline Spain & 6 & 4 & 11 & 4 & 9 & 14 & 7 & 17 & 11 & 11 & 2 & 9 & 6 & 4 & 7 & 10 \\
\hline Sweden & 6 & 8 & 5 & 12 & 9 & 3 & 4 & 3 & 8 & 3 & 4 & 3 & 2 & 5 & 3 & 5 \\
\hline Switzerland & 2 & 2 & 1 & 3 & 1 & 5 & 8 & 5 & 22 & 15 & 2 & 4 & 3 & 2 & 3 & .. \\
\hline Turkey & 29 & 30 & 27 & 30 & 28 & & .. & .. & 30 & 30 & 30 & 30 & 30 & 30 & 27 & . \\
\hline United Kingdom & 17 & 22 & 15 & 21 & 12 & 21 & 22 & 18 & 26 & 22 & 19 & 16 & 19 & 18 & 16 & 18 \\
\hline United States & 24 & 23 & 24 & 18 & 12 & 24 & 26 & 23 & 22 & 28 & 22 & 22 & 22 & 20 & 20 & 21 \\
\hline
\end{tabular}

1. Life expectancy: 2006 for Canada, Italy, the United Kingdom and the United States. Potential years of life lost adjusted: 2003 for Portugal; 2004 for Austria and Canada; 2005 for Hungary, Luxembourg, New Zealand, the Slovak Republic, Spain and the United States; 2006 for Denmark, France, Germany, Italy, Korea, Mexico, Norway, Poland, Sweden and Switzerland. Perinatal mortality: 2005 for Australia, Belgium. Denmark, Ireland, New Zealand, Spain and the United States; 2006 for Canada, France, Italy and Korea. Infant mortality: 2006 for Canada, France and the United States. HALE: 2002 for all countries. Amenable mortality: 2003 for Portugal; 2004 for Australia and Canada; 2005 for Hungary, Luxembourg, New Zealand, the Slovak Republic, Spain and the United States; 2006 for Denmark, France, Germany, Italy, Korea, Mexico, Norway, Poland and Sweden.

2. Potential years of life lost (PYLL) are calculated excluding deaths from land transport accidents, accidental falls, suicides and assaults. PYLL data are missing for Belgium and Turkey.

作 Source: OECD Health Data 2009; WHO, World Health Report 2004 Statistical Annex. 
Table A2.2. Correlations between different measures of health outcomes

Common (Pearson) and rank (Spearman) coefficients for $2007^{1}$

\section{Raw mortality indicators}

Life expectancy at birth, female

Life expectancy at birth, male

Life expectancy at 65 , female

Life expectancy at 65 , male

Adjusted PYLL, total ${ }^{2}$

Adjusted PYLL, female

Adjusted PYLL, male ${ }^{2}$

Perinatal mortality

Infant mortality

Health-adjusted indicators

Health-adjusted life expectancy at birth, total Health-adjusted life expectancy at birth, female Health-adjusted life expectancy at 60 , male

Other indicators

Amenable mortality ${ }^{4}$
Life expectancy at birth, total Health-adjusted life expectancy at birth, male

\begin{tabular}{|c|c|c|c|c|c|c|c|c|c|c|c|c|c|c|c|}
\hline \multicolumn{5}{|c|}{ Life expectancy } & \multirow{2}{*}{\multicolumn{3}{|c|}{ Adjusted PYLL ${ }^{2}$}} & \multirow{3}{*}{$\begin{array}{l}\text { Perinatal } \\
\text { mortality }\end{array}$} & \multirow{3}{*}{$\begin{array}{c}\text { Infant } \\
\text { mortality }\end{array}$} & \multicolumn{5}{|c|}{ Health-adjusted life expectancy ${ }^{3}$} & \multirow{3}{*}{$\begin{array}{l}\text { Amenable } \\
\text { mortality }\end{array}$} \\
\hline \multicolumn{3}{|c|}{ at birth } & \multicolumn{2}{|c|}{ at 65} & & & & & & & at birth & & at 6 & & \\
\hline Total & Female & Male & Female & Male & Total & Female & Male & & & Total & Female & Male & Female & Male & \\
\hline 1.00 & $0.97^{* *}$ & $0.98^{* *}$ & $0.94^{* *}$ & $0.92 * *$ & $-0.93^{* *}$ & $-0.83^{* *}$ & $*-0.94 * *$ & $-0.58 * \star$ & $-0.67^{* *}$ & $0.96^{* *}$ & $0.92^{* *}$ & $0.95^{* *}$ & $0.91^{* *}$ & * $0.90^{* *}$ & -0.96 ** \\
\hline $0.91^{* \star}$ & * 1.00 & $0.89 * *$ & $0.97^{* *}$ & $0.84 * \star$ & $-0.88^{* *}$ & $-0.85^{\text {** }}$ & $*-0.86$ ** & -0.66 ** & $-0.74^{* \star}$ & $0.94 * *$ & $0.95^{\text {** }}$ & 0.89 ** & 0.94 ** & * $0.82^{* \star}$ & -0.89 ** \\
\hline $0.97^{\star *}$ & * 0.81 ** & 1.00 & $0.86^{* *}$ & 0.94 * & $-0.92^{* *}$ & $-0.77^{\star *}$ & * $-0.96 *$ & $-0.50 * \star$ & $-0.58 * *$ & $0.93^{* *}$ & $0.85^{* *}$ & $0.96^{* *}$ & $0.85^{* *}$ & * $0.92 * *$ & $-0.95 * *$ \\
\hline $0.89^{* *}$ & * $0.97^{* *}$ & $0.78^{* *}$ & 1.00 & $0.88^{* *}$ & $-0.77^{* *}$ & $-0.70^{* *}$ & * $-0.77^{* *}$ & $-0.57^{\star *}$ & $-0.64 * *$ & $0.91^{* *}$ & $0.93^{\text {** }}$ & 0.85 ** & $0.95^{* *}$ & * $0.83 * *$ & -0.86 ** \\
\hline $0.92^{* *}$ & * $0.80 * *$ & $0.91^{\star *}$ & $0.82^{* *}$ & 1.00 & $-0.74^{* *}$ & $-0.55^{* *}$ & $*-0.81 * *$ & $-0.39 *$ & $-0.44 *$ & $0.87^{* *}$ & $0.81^{\star \star}$ & 0.90 ** & $0.84^{* *}$ & * $0.94 * *$ & -0.89 ** \\
\hline$-0.82^{* *}$ & * -0.71 ** & $-0.85^{* *}$ & $-0.64^{* *}$ & $-0.64 *$ & 1.00 & $0.95^{* *}$ & * $0.98 * *$ & $0.61^{\star *}$ & $0.76^{* *}$ & -0.90 ** & $-0.85^{\star *}$ & -0.90 ** & $-0.77^{* *}$ & $-0.78 * *$ & $0.91^{\text {** }}$ \\
\hline$-0.74^{* *}$ & * $\quad-0.76$ ** & $-0.68 * *$ & -0.66 ** & -0.55 * & $0.86^{\star *}$ & 1.00 & $0.87^{* *}$ & $0.74 * \star$ & $0.89 * *$ & $-0.81^{* *}$ & * -0.81 ** & -0.78 * & $-0.70^{* *}$ & $-0.63^{* \star}$ & 0.79 ** \\
\hline$-0.83^{* *}$ & * -0.66 ** & $-0.90^{* *}$ & $-0.61^{* *}$ & -0.68 * & $0.97^{\text {** }}$ & $0.75^{\star *}$ & 1.00 & $0.51^{\star \star}$ & 0.64 ** & -0.90 ** & * $\quad-0.83^{\text {** }}$ & -0.92 ** & $-0.76^{* *}$ & $=-0.82 * *$ & $0.94^{* *}$ \\
\hline-0.42 * & -0.46 * & -0.39 * & -0.34 * & -0.29 & $0.56^{* *}$ & $0.68^{* *}$ & * $0.48 * *$ & 1.00 & $0.93 * *$ & -0.65 ** & -0.71 ** & -0.57 * & -0.54 ** & -0.39 & 0.35 * \\
\hline$-0.47^{* *}$ & * -0.52 ** & -0.45 * & -0.39 * & -0.31 & $0.65^{\text {** }}$ & $0.72^{* *}$ & * $0.55^{\text {** }}$ & $0.67^{* *}$ & 1.00 & $-0.74^{* *}$ & * $\quad-0.79$ ** & -0.66 ** & $-0.65^{* *}$ & * $-0.48 * *$ & $0.54^{\star \star}$ \\
\hline $0.95^{* \star}$ & 0.90 ** & $0.92^{* *}$ & $85^{* *}$ & $0.86 * \star$ & $-0.84^{* *}$ & $-0.78^{* *}$ & $*-0.83 * *$ & $-0.46 * *$ & $-0.59 * *$ & 1.00 & 0.98 ** & 0.98 ** & $0.95^{* *}$ & * $0.92^{* *}$ & -0.89 ** \\
\hline 0.91 & 0 & $0.85^{* *}$ & & $0.83 * \star$ & -0 & -0.7 & ${ }^{*}-0.7$ & & & $0.97^{* \star}$ & 1. & 0.91 ** & $0.97^{* *}$ & & \\
\hline 0.95 ** & 0 & 0.96 ** & & $0.89 * \star$ & ** & $-0.72^{* *}$ & -0.8 & - & -0 & $0.97^{\text {** }}$ & 0.91 ** & 1.00 & $0.90^{* *}$ & * $0.96^{* \star}$ & 1 ** \\
\hline $0.90^{* *}$ & $0.93^{* *}$ & 0.82 ** & $0.93^{* *}$ & $0.83^{* \star}$ & $-0.71^{* \star}$ & -0.69 ** & ${ }^{*}-0.68 *$ & -0.3 & $-0.49 *$ & $0.94^{* *}$ & $0.98^{* *}$ & 0.87 ** & * 1.00 & $0.89 * \star$ & -0.81 ** \\
\hline $0.93^{* *}$ & * $\quad 0.86$ ** & 0.90 ** & $0.83^{* *}$ & $0.92 * \star$ & $-0.78^{* \star}$ & -0.74 ** & $*-0.76 * \star$ & $-0.42 *$ & $-0.54^{\star \star}$ & $0.96^{* *}$ & * $\quad 0.93^{* *}$ & 0.95 ** & * $\quad 0.92^{\text {** }}$ & 1.00 & $-0.87^{* \star}$ \\
\hline$-0.92^{* *}$ & * $\quad-0.87^{* *}$ & $-0.87^{* *}$ & -0.82 ** & $-0.77 *$ & $0.85^{* *}$ & 0.79 ** & * $0.82 * *$ & 0.40 * & $0.57^{\star \star *}$ & -0.93 ** & $-0.88^{* *}$ & $-0.89 *$ & -0.89 ** & -0.91 ** & 1.00 \\
\hline
\end{tabular}

1. Pearson coefficients, which are shown above the diagonal, measure the linear correlation between the levels of different health status measures across countries in 2007 or latest year for which data are available. Spearman coefficients, displayed in the shaded area, measure the correlation between the ranks of the countries ordered according to the relevant variables. Coefficients with ** are significant at less than $1 \%$.

Those with * are significant at between 1 and $10 \%$. Those with no * are not significant below a $10 \%$ threshold. Data availability varies, affecting the degree of significance of coefficient estimates.

2. Potential years of life lost (PYLL) are calculated excluding deaths from land transport accidents, accidental falls, suicides and assaults. PYLL data are missing for Belgium and Turkey.

3. Health-adjusted life expectancy (HALE) data are for 2002 .

Age-standardised deaths rates per 100000 people. Data are missing for Belgium, Switzerland and Turkey.

Source: OECD Health Data 2009; WHO, World Health Report 2004 Statistical Annex. 
ECO/WKP(2010)25

Table A2.3. Bilateral correlations across efficiency measures based on outputs and quality indicators

\begin{tabular}{|c|c|c|}
\hline \multicolumn{2}{|c|}{ Outcomes measures } & \multirow[b]{2}{*}{$\begin{array}{l}\text { Efficiency } \\
\text { measure } \\
\text { based on } \\
\text { outcomes } \\
\text { DEA } \\
\text { scores }\end{array}$} \\
\hline $\begin{array}{c}\text { Life } \\
\text { expectanc }\end{array}$ & $\begin{array}{l}\text { Amenable } \\
\text { mortally }\end{array}$ & \\
\hline 0.46 & -026 & 0.40 * \\
\hline 0.21 & -0.04 & -0.01 \\
\hline 0.01 & 0.09 & -0.08 \\
\hline 0.57 & -0.40 , & 0.38 * \\
\hline 0.67 & $-0.53^{*}$ & 0.33 * \\
\hline 0.16 & -0.08 & 0.13 \\
\hline-0.26 & 0.32 & 0.14 \\
\hline-0.20 & 0.01 & -0.20 \\
\hline $0.62^{\circ}$ & -0.48 * & 0.17 \\
\hline & $-0.72 * *$ & \\
\hline-0.20 & 0.21 & 0.12 \\
\hline-0.51. & $0.50 * *$ & -0.13 \\
\hline-0.24 & 0.33 * & 0.18 \\
\hline 0.56 & $-0.61 *$ & $0.39^{\circ}$ \\
\hline-0.46 & $0.49^{*}$ & $-0.39 *$ \\
\hline-0.50 & 0.31 & -0.48 \\
\hline-0.49 & 0.39 *: & -0.29 \\
\hline $\begin{array}{l}-0.39 \\
-0.29\end{array}$ & $\begin{array}{l}0.41 \\
0.40\end{array}$ & $\begin{array}{l}-0.21 \\
-0.33\end{array}$ \\
\hline-0.05 & 0.04 & -0.10 \\
\hline 1.00 & $-0.96 *$ & $0.45^{\circ}$ \\
\hline & 1.00 & $\begin{array}{l}-0.52^{* *} \\
100\end{array}$ \\
\hline
\end{tabular}

Efficiency measures based on outputs

ALOS, Breast cancer

ALOS, Trachea, bronchus and lung cancer

ALOS, Fracture of femur

ALOS, Tuberculosis

Turnover rate, acute care beds
Occupancy rate, acute care beds

Cataract surgery - \% performed as day cases

Quality indicators

Vaccination rates, diphtheria, tetanus, and pertussis (DTP)

Avoidable hospital admissions: Chronic obstructive pulmonary diseases

in-hospital case fatality rates for a cuestive heart alures

In-hospital case fatality rates for ischemic stroke

Administrative costs

$\frac{\text { Measures of outcomes }}{\text { Life expectancy at bith }}$

Amenable mortality rates

Aficiency measure based on outcomes: DEA scores

Efficiency measures based on outputs

Quality indicators

Average length of stay (ALOS)

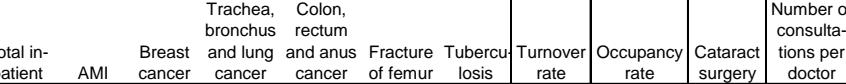

\begin{tabular}{|c|c|c|}
\hline \\
\hline $\begin{array}{l}\text { Care for communicable } \\
\text { diseases }\end{array}$ & $\begin{array}{l}\text { Care for chronic conditions: } \\
\text { avoidable admissions }\end{array}$ & Fatality rates \\
\hline & $\begin{array}{l}\text { Chronic } \\
\text { obstructive Conges- } \\
\text { pulmonary tive hear }\end{array}$ & ch \\
\hline
\end{tabular}

$\begin{array}{llllll}0.27 & 0.24 & 0.35 * & 0.33 * 0.38 * 0.17 \\ 1.00 & 0.50 * & 0.39 * & 0.28 & 0.54 * & 0.28\end{array}$

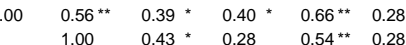

$\begin{array}{lllll}1.00 & 0.43 * & 0.28 & 0.54 * * & 0.28 \\ & 1.00 & 0.82 * & 0.46 * & -0.01 \\ & & & 1.00 & 0.27\end{array} \mid$

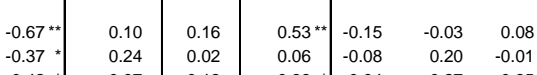

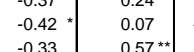

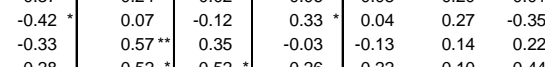

0.27
1.00

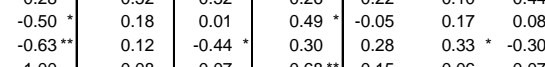

Notes: Pearson coefficients measure the linear corre

Source: OECD Health Data 2009; OECD calculations. 
Figure A2.1. DEA: 2007 output-oriented efficiency scores and their confidence intervals ${ }^{1}$

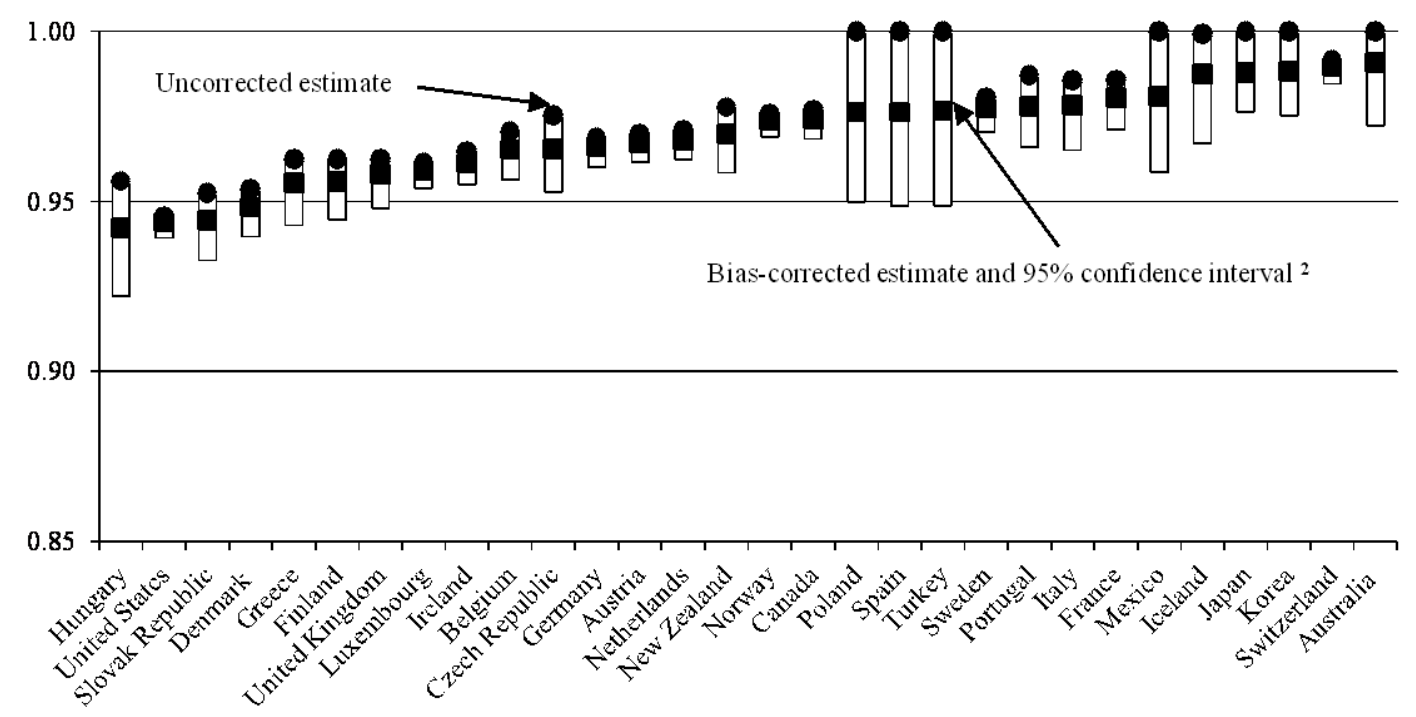

1. DEA performed with two inputs (health care spending, a composite indicator made of socio-economic conditions,

consumption of fruits and vegetables, lagged consumption of alcohol and tobacco) and one outcome (life expectancy at birth).

2. DEA results are sensitive to measurement errors and statistical noise. They are also plagued by a bias towards smaller

inefficiency estimates. Bootstrapping (i.e. taking repeated samples that are the same size as observed data) can help address these problems by making a correction for the bias resulting from the small sample size and producing confidence intervals. Source: OECD Secretariat estimates. 
ECO/WKP(2010)25

Annex 3.

Individual country profiles 


\title{
Definition of health indicators presented in each individual country profile
}

\author{
Limitations in data comparability are, in some cases, severe. For instance, the definition of acute care varies across countries and \\ the low number of doctor consultations in some countries may reflect the fact that the first contact with the health care system is \\ often with nurses. Similarly, statistics on the health workforce are expressed in numbers of persons rather than full-time equivalent. \\ The definition of nurses, consultations, supply and use of medical technologies and hospital discharges also differs across \\ countries. Data concern 2007 or the latest year available. For more details, see OECD (2009a).

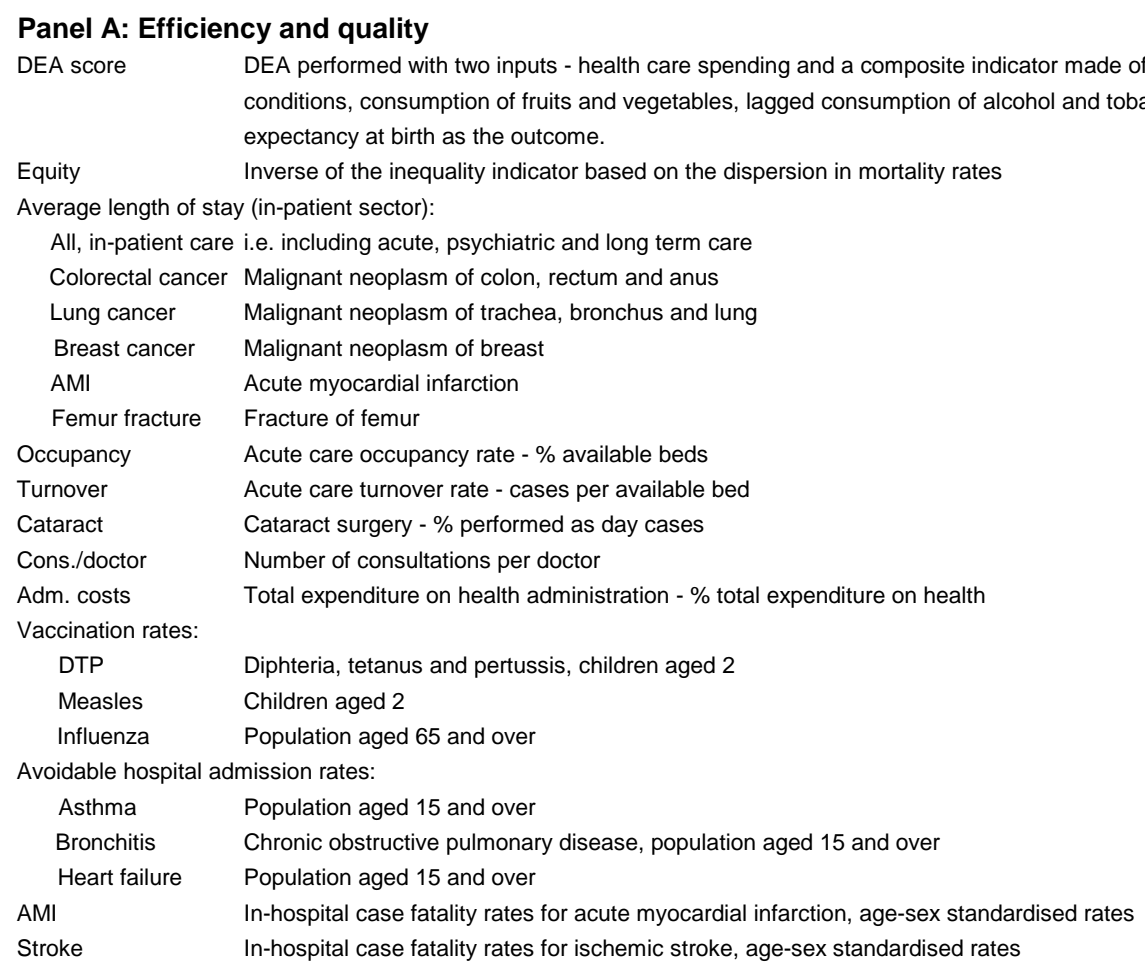

Panel B. Amenable mortality by group of causes

Amenable mortality is defined as those deaths that were potentially preventable by timely and effective medical care (for more details, see box 2).

$\begin{array}{ll}\begin{array}{l}\text { Total } \\ \text { Infectious }\end{array} & \text { All causes } \\ \text { Cancers } & \text { Infectious diseases } \\ \text { Endocrine } & \text { Endocrine, nutritional and metabolic diseases } \\ \text { Nervous } & \text { Diseases of nervous system } \\ \text { Circulatory } & \text { Diseases of circulatory system } \\ \text { Genitory } & \text { Diseases of genitor-urinary system } \\ \text { Respiratory } & \text { Diseases of respiratory system } \\ \text { Digestive } & \text { Diseases of digestive system } \\ \text { Perinatal } & \text { Perinatal mortality }\end{array}$

Panel C: Prices and physical resources

Spending per capita Total health expenditure - per capita, US\$ PPP

Doctors Practising physicians - Density per 1000 population

Nurses Practising nurses - Density per 1000 population

Students Medical graduates - Density per 100000 population

MRIs Magnetic resonance imaging units - per million population

Scanners Computed tomography scanners - per million population

Hospital beds Number of acute care beds per 1000 population

Rem. nurses Remuneration of hospital nurses - Salaried, income per capita GDP

Rem. GPs Remuneration of general practitioners - Self-employed or salaried, income per capita GDP

Rem. spec. Remuneration of specialists - Self-employed or salaried, income per capita GDP

HC prices Relative health prices to GDP, 2005 PPPs 
ECO/WKP(2010)25

Panel D: Activity and consumption

Spending to GDP Total health expenditure - \% GDP

Consultations

Discharges

Doctor consultations - number per capita

Hip replac.

Knee replac.

Append.

Hospital discharges, all causes - per 100000 population

Hip replacement, number of procedures per 100000 population

Knee replacement, number of procedures per 100000 population

Caesareans

Antidepressants

Anxiolytics

Analgesics

Anti-inflam

Antibiotics

Cardiovasc.

Antidiabetics

Appendectomy, number of procedures per 100000 population (in-patient)

Caesareans sections - per 100 live births

Antidepressants - defined daily dosage per 1000 population, per day

Anxiolytics - defined daily dosage per 1000 inhabitants, per day

Analgesics - defined daily dosage per 1000 population, per day

Antiinflamatory, antirheumatism - defined daily dosage per 1000 inhabitants, per day

Antibacterials for systemic use - defined daily dosage per 1000 inhabitants, per day

Cardiovascular system - defined daily dosage per 1000 inhabitants, per day

Drugs for diabetes - defined daily dosage per 1000 inhabitants, per day

\section{Panel E: Financing and spending mix}

Public spending Public spending - \% of total health expenditure (THE)

Taxes General government funding excluding social expenditure - \% THE

SS Social security funding - \% THE

$\mathrm{PHI} \quad$ Private health insurance funding - \% THE

OOP Out-of-pocket payments - \% THE

Drugs $\quad$ Expenditure on medical goods - \% THE

Out-patient Expenditure on out-patient care, including home-care and ancillary services, \% THE

In-patient Expenditure on in-patient and day care - \% THE

Collective $\quad$ Expenditure on collective services (public health services and health administration) - \% THE

\section{Panel F: Policy and institutions}

Breadth

Scope

Depth

Choice insurer

Insurer levers

Over-the-basic

Choice prov.

Gatekeeping

User price

Decentralisation

Delegation

Consistency

Priority

Budg. const.

Private prov.

Vol. incentives

Reg. price 3rd

Reg. price prov

Reg. resources

User information
Breadth of coverage - population covered

Scope of basic coverage

Scope of coverage

User choice of insurer, basic coverage

Levers for competition on the market for the basic insurance package

Over-the-basic coverage: market forces

Patient choice among providers

Gatekeeping

Price signals on users

Degree of decentralisation to sub-national governments

Degree of delegation to insurers

Consistency in responsibility assignment across levels of government

Priority setting

Stringency of the budget constraint

Degree of private provision

Volume incentives embedded in provider payment schemes

Regulation of prices paid by third-party payers

Regulation of prices billed by providers

Regulation of the workforce and equipment

User information on quality and prices 


\section{Australia: health care indicators}

Group 2: Australia, Belgium, Canada, France

A. Efficiency and quality

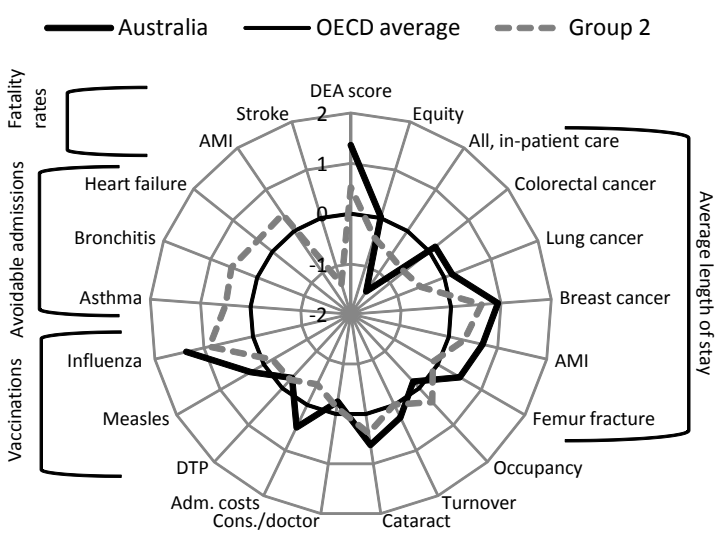

C. Prices and physical resources

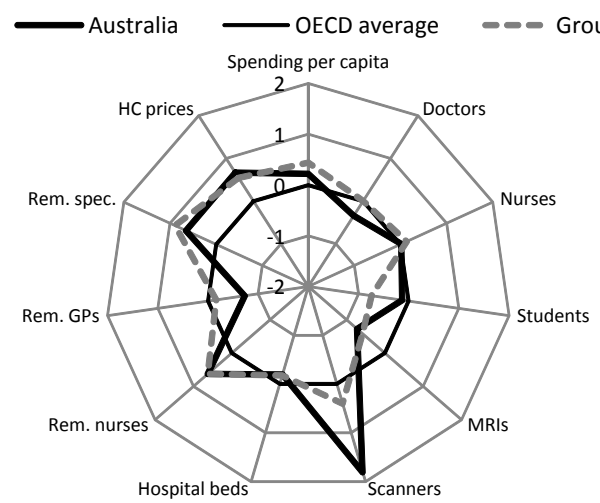

E. Financing and spending mix

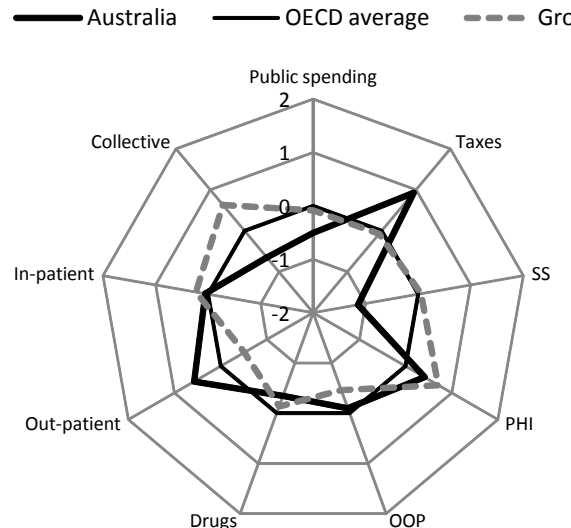

B. Amenable mortality by group of causes

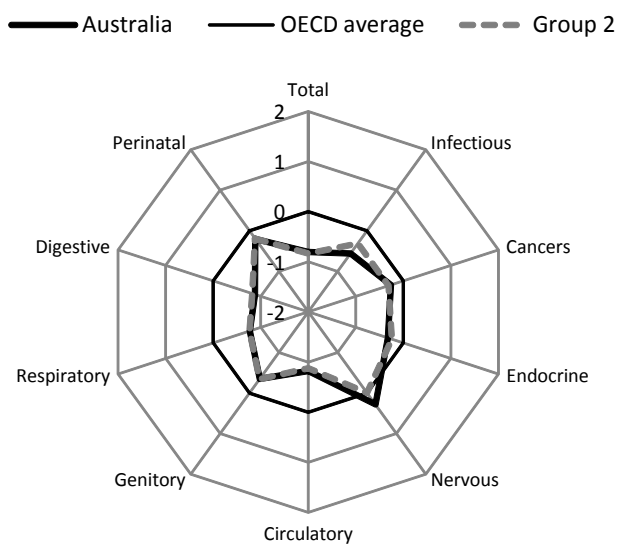

D. Activity and consumption

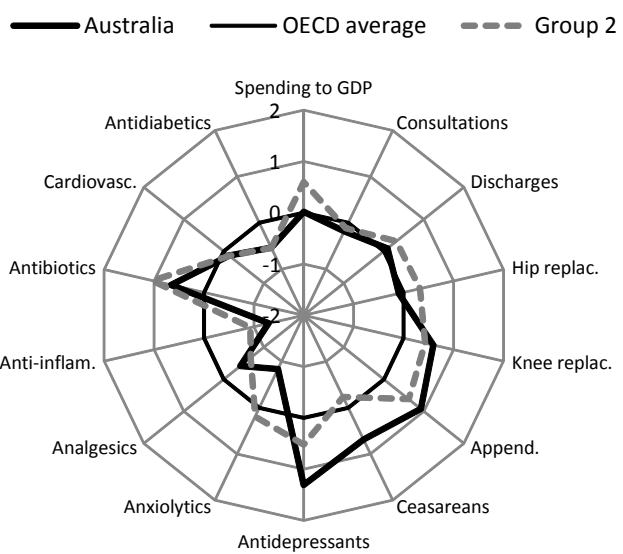

F. Policy and institutions

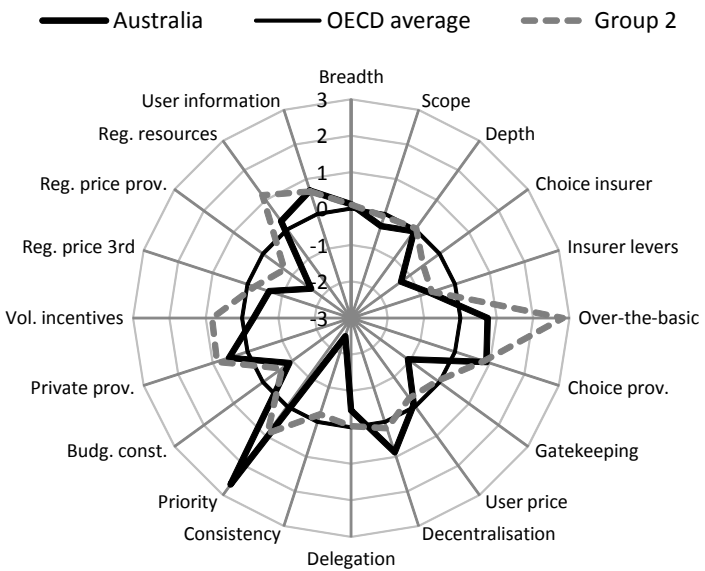

Note: Country groups have been determined by a cluster analysis performed on policy and institutional indicators. In all panels except Panel A, data points outside the average circle indicate that the level of the variable for the group or the country under scrutiny is higher than the average OECD country (e.g. Australia has more scanners than the OECD average country).

In Panel A, data points outside the average circle indicate that the group or the country under scrutiny performs better than the OECD average (e.g. administrative costs as a share of total health care spending are lower in Australia than on average in the OECD area). In all panels except Panel F, data represent the deviation from the OECD average and are expressed in number of standard deviations. In Panel $\mathrm{F}$, data shown are simple deviations from the OECD average.

Source: OECD Health Data 2009; OECD Survey on Health Systems Characteristics 2008-2009; Preliminary OECD work based on Nolte and Mc Kee (2008) 
ECO/WKP(2010)25

\section{Austria: health care indicators}

Group 3: Austria, Czech Republic, Greece, Japan, Korea, Luxembourg

A. Efficiency and quality

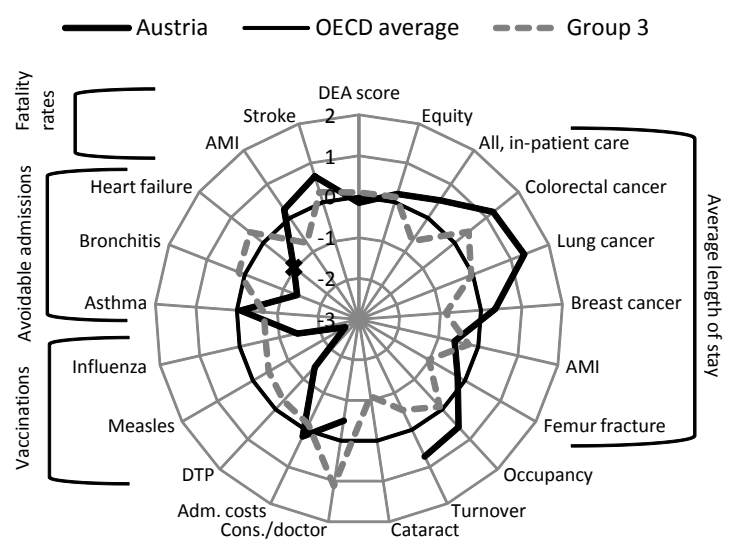

C. Prices and physical resources

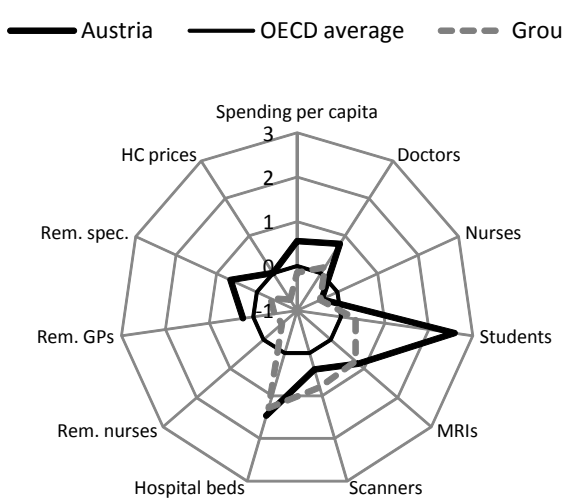

E. Financing and spending mix

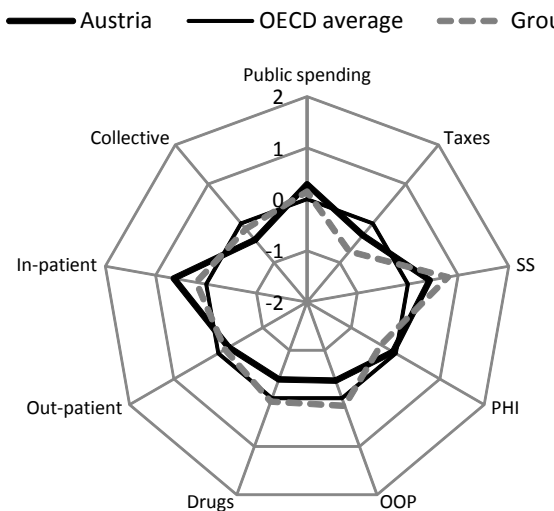

B. Amenable mortality by group of causes

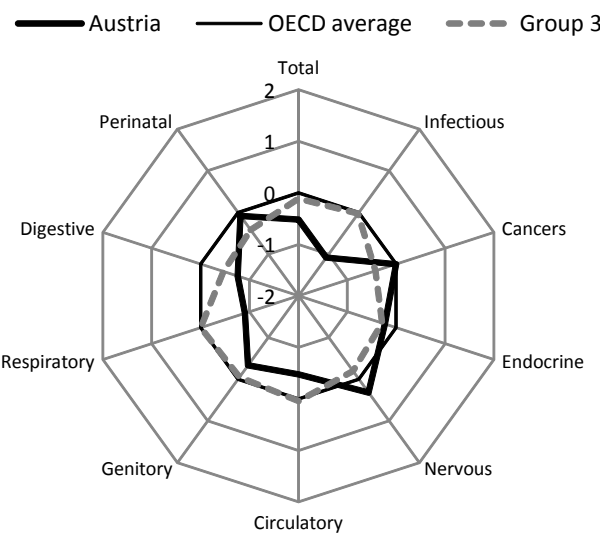

D. Activity and consumption

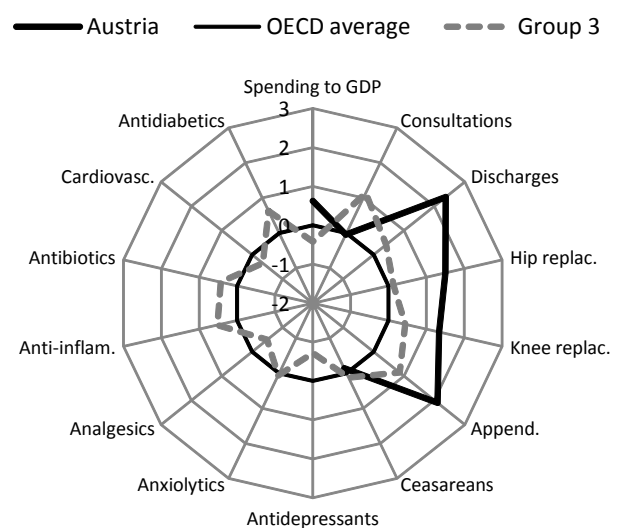

F. Policy and institutions

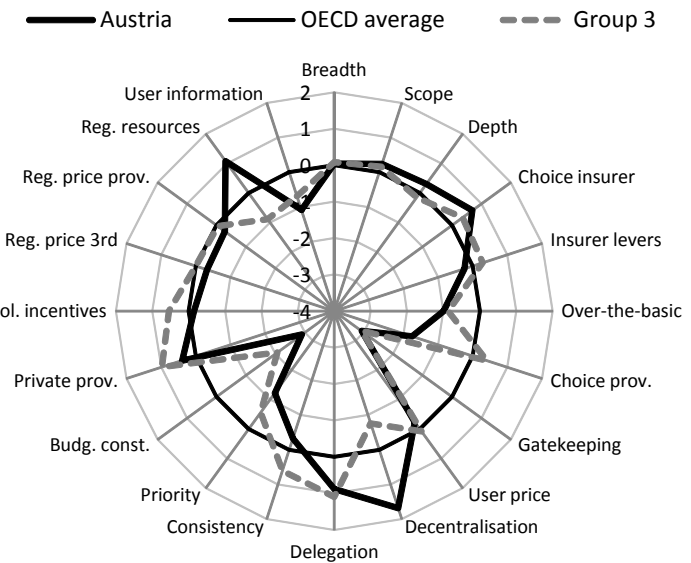

Note: Country groups have been determined by a cluster analysis performed on policy and institutional indicators. In all panels except Panel A, data points outside the average circle indicate that the level of the variable for the group or the country under scrutiny is higher than the average OECD country (e.g. Australia has more scanners than the OECD average country).

In Panel A, data points outside the average circle indicate that the group or the country under scrutiny performs better than the OECD average (e.g. administrative costs as a share of total health care spending are lower in Australia than on average in the OECD area). In all panels except Panel F, data represent the deviation from the OECD average and are expressed in number of standard deviations. In Panel $\mathrm{F}$, data shown are simple deviations from the OECD average.

Source: OECD Health Data 2009; OECD Survey on Health Systems Characteristics 2008-2009; Preliminary OECD work based on Nolte and Mc Kee (2008) 


\section{Belgium: health care indicators}

Group 2: Australia, Belgium, Canada, France

A. Efficiency and quality

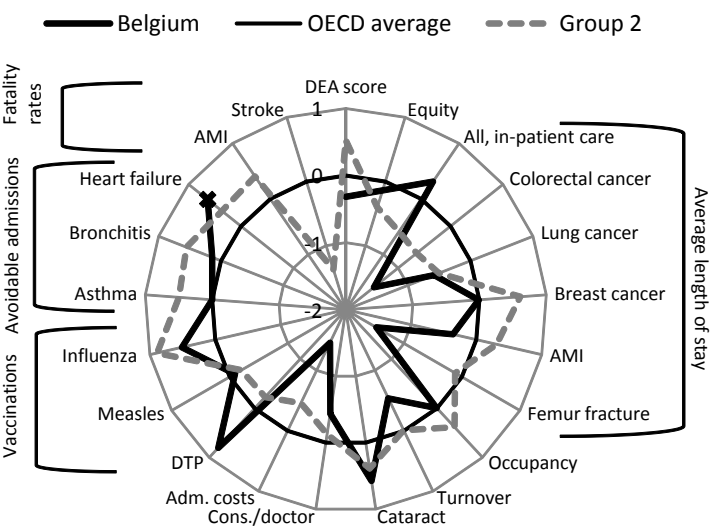

C. Prices and physical resources

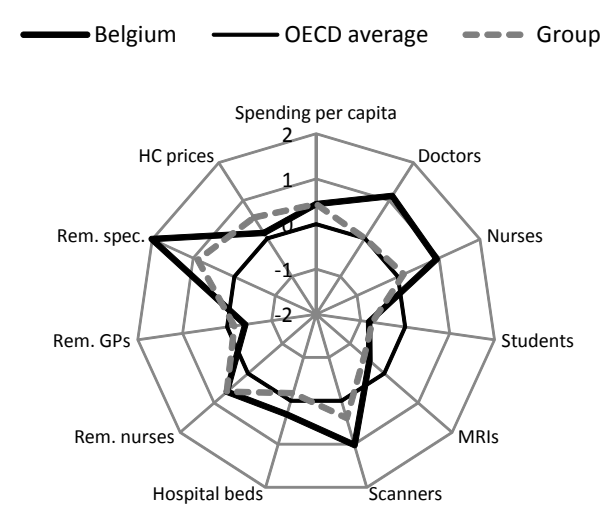

E. Financing and spending mix

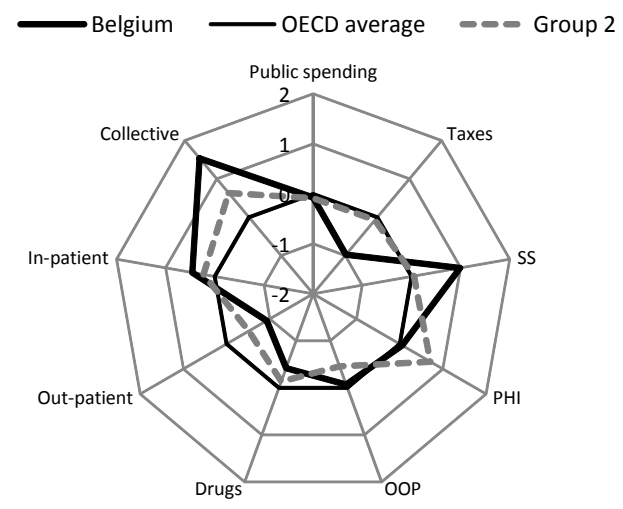

B. Amenable mortality by group of causes
D. Activity and consumption

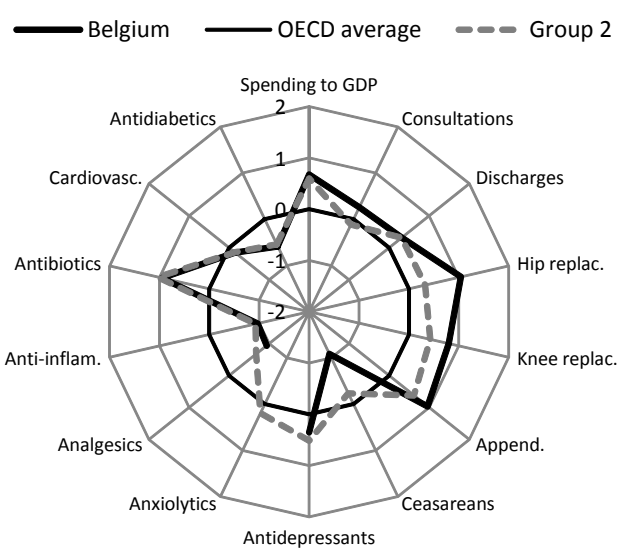

F. Policy and institutions

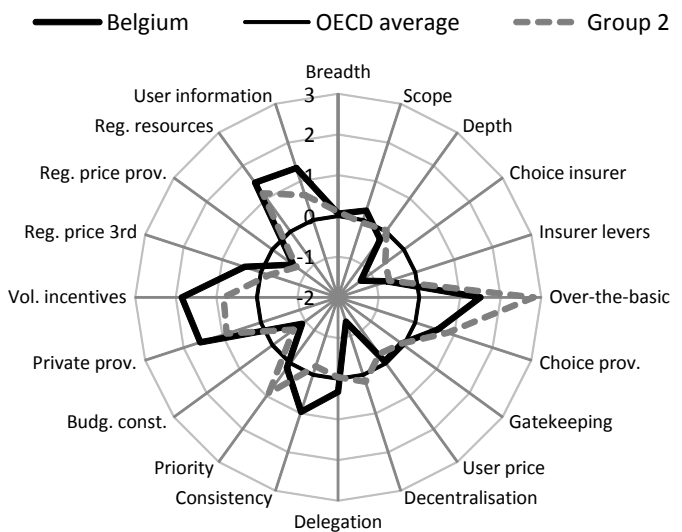

Note: Country groups have been determined by a cluster analysis performed on policy and institutional indicators. In all panels except Panel A, data points outside the average circle indicate that the level of the variable for the group or the country under scrutiny is higher than the average OECD country (e.g. Australia has more scanners than the OECD average country).

In Panel A, data points outside the average circle indicate that the group or the country under scrutiny performs better than the OECD average (e.g. administrative costs as a share of total health care spending are lower in Australia than on average in the OECD area). In all panels except Panel F, data represent the deviation from the OECD average and are expressed in number of standard deviations. In Panel $\mathrm{F}$, data shown are simple deviations from the OECD average.

Source: OECD Health Data 2009; OECD Survey on Health Systems Characteristics 2008-2009; Preliminary OECD work based on Nolte and Mc Kee (2008) 
ECO/WKP(2010)25

\section{Canada: health care indicators}

Group 2: Australia, Belgium, Canada, France

A. Efficiency and quality

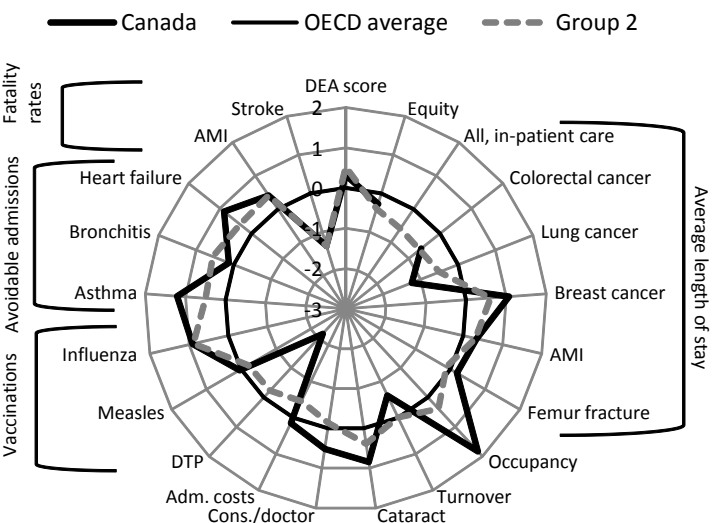

C. Prices and physical resources

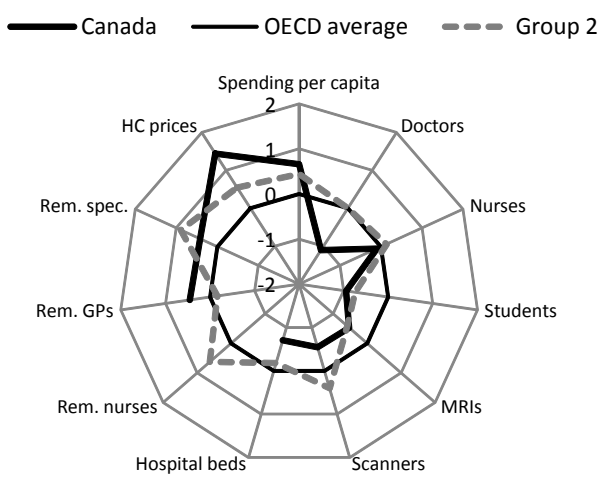

E. Financina and spendina mix

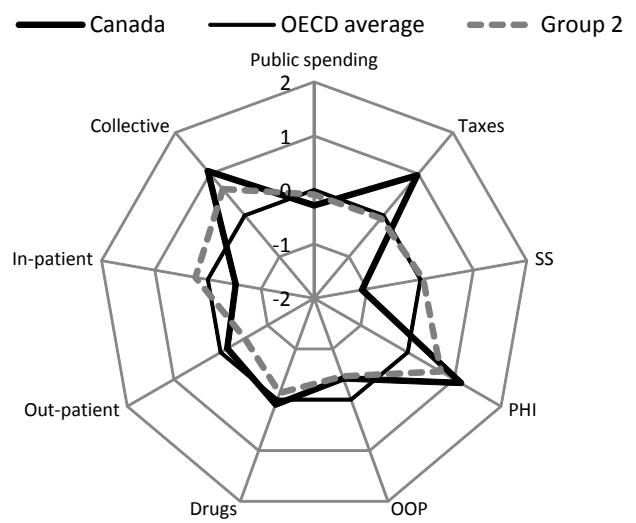

B. Amenable mortality by group of causes

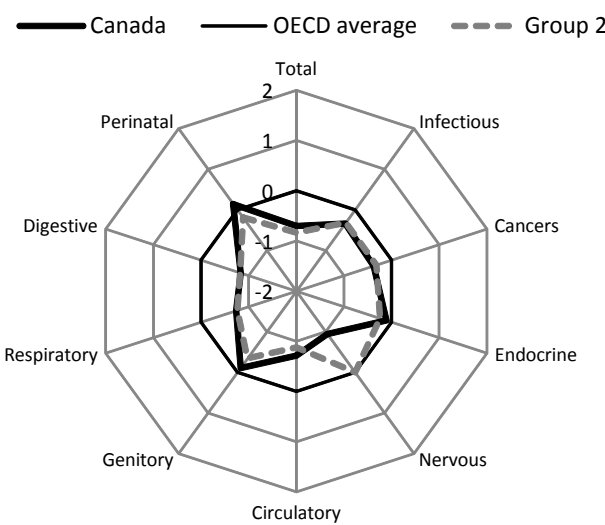

D. Activity and consumption

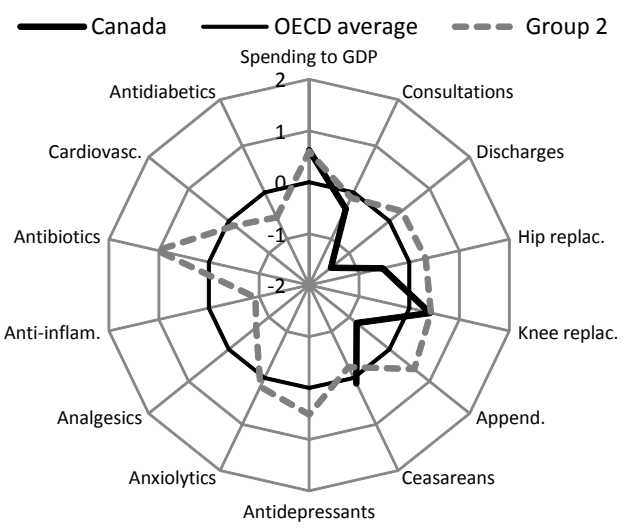

F. Policy and institutions

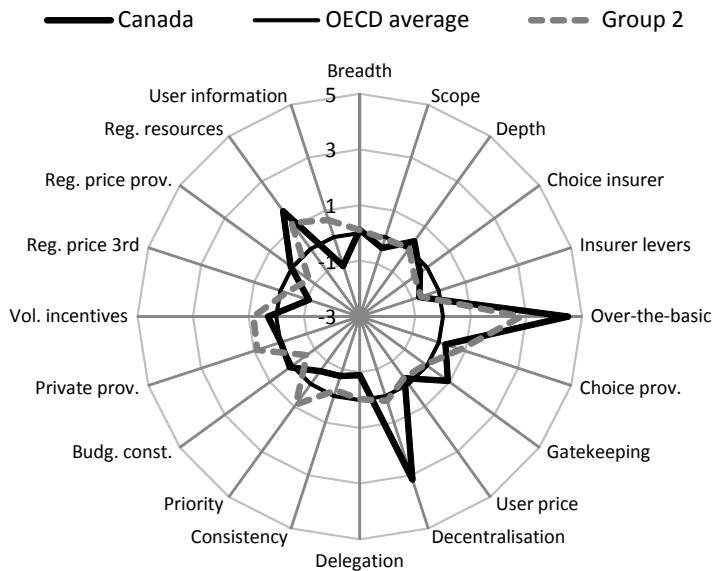

Note: Country groups have been determined by a cluster analysis performed on policy and institutional indicators. In all panels except Panel A, data points outside the average circle indicate that the level of the variable for the group or the country under scrutiny is higher than the average OECD country (e.g. Australia has more scanners than the OECD average country).

In Panel A, data points outside the average circle indicate that the group or the country under scrutiny performs better than the OECD average (e.g. administrative costs as a share of total health care spending are lower in Australia than on average in the OECD area). In all panels except Panel F, data represent the deviation from the OECD average and are expressed in number of standard deviations. In Panel $\mathrm{F}$, data shown are simple deviations from the OECD average.

Source: OECD Health Data 2009; OECD Survey on Health Systems Characteristics 2008-2009; Preliminary OECD work based on Nolte and Mc Kee (2008) 


\section{Czech Republic: health care indicators}

Group 3: Austria, Czech Republic, Greece, Japan, Korea, Luxembourg

A. Efficiency and quality

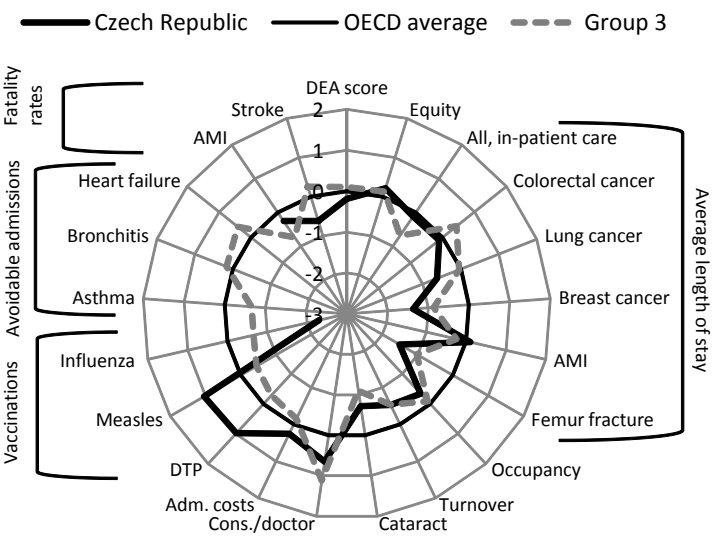

C. Prices and physical resources

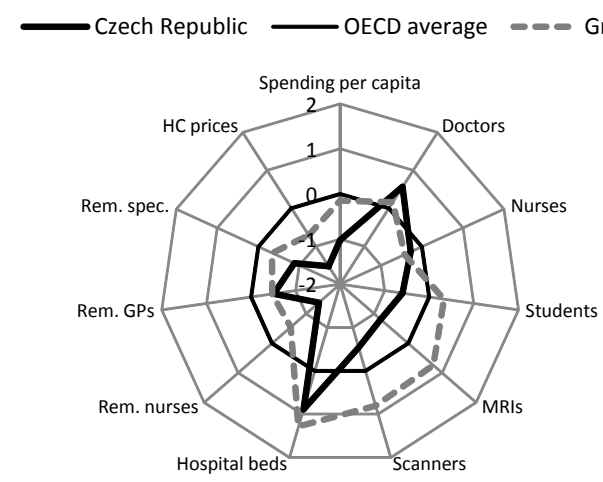

E. Financing and spending mix

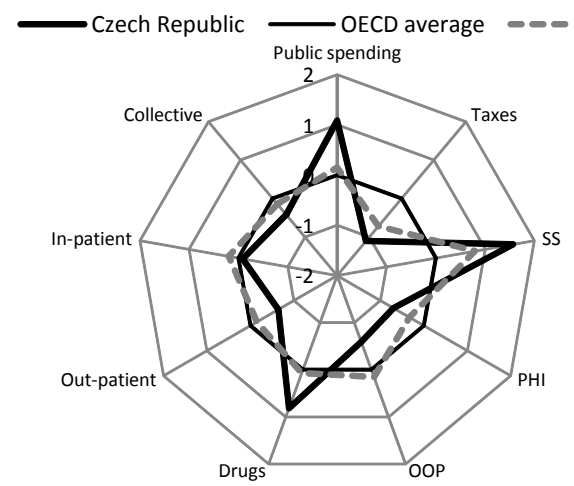

B. Amenable mortality by group of causes

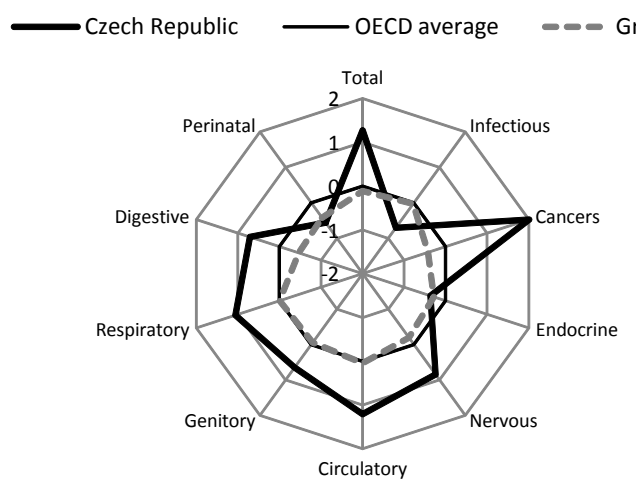

D. Activity and consumption

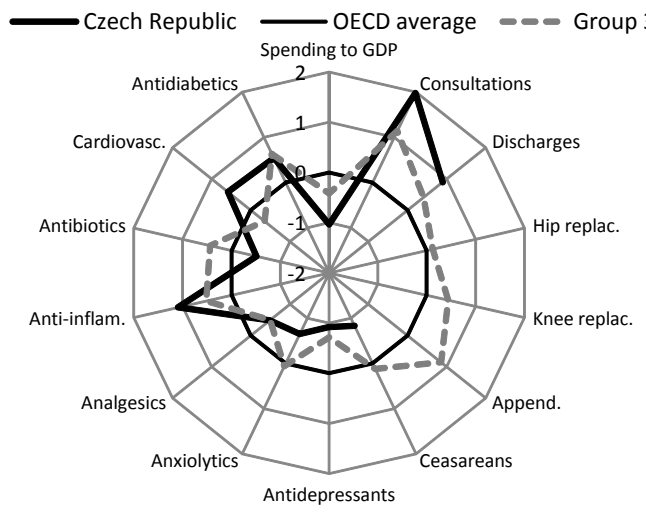

F. Policy and institutions

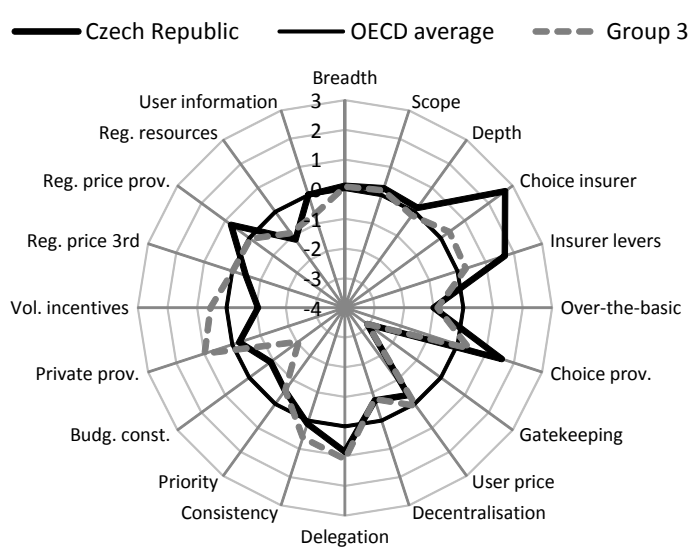

Note: Country groups have been determined by a cluster analysis performed on policy and institutional indicators. In all panels except Panel A, data points outside the average circle indicate that the level of the variable for the group or the country under scrutiny is higher than the average OECD country (e.g. Australia has more scanners than the OECD average country).

In Panel A, data points outside the average circle indicate that the group or the country under scrutiny performs better than the OECD average (e.g. administrative costs as a share of total health care spending are lower in Australia than on average in the OECD area). In all panels except Panel F, data represent the deviation from the OECD average and are expressed in number of standard deviations. In Panel $\mathrm{F}$, data shown are simple deviations from the OECD average.

Source: OECD Health Data 2009; OECD Survey on Health Systems Characteristics 2008-2009; Preliminary OECD work based on Nolte and Mc Kee (2008) 
ECO/WKP(2010)25

Denmark: health care indicators

Group 5: Denmark, Finland, Mexico, Portugal, Spain

A. Efficiency and quality

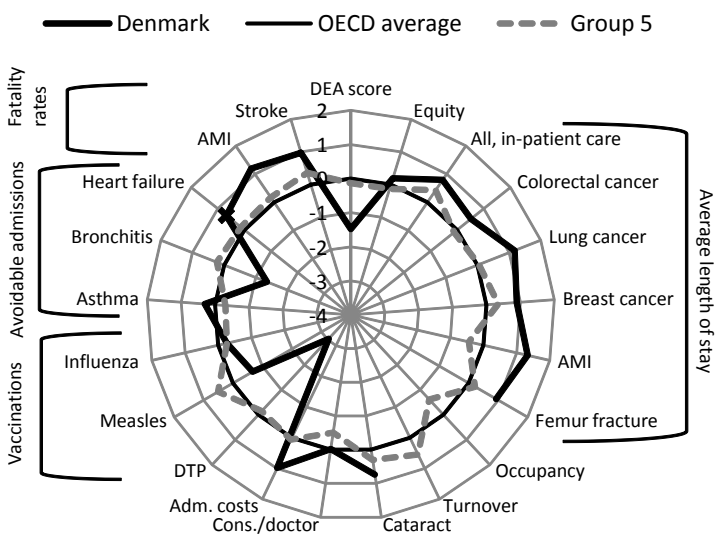

C. Prices and physical resources

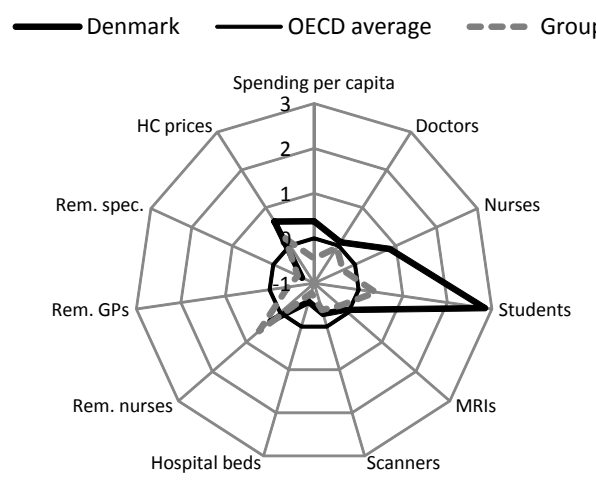

E. Financing and spending mix

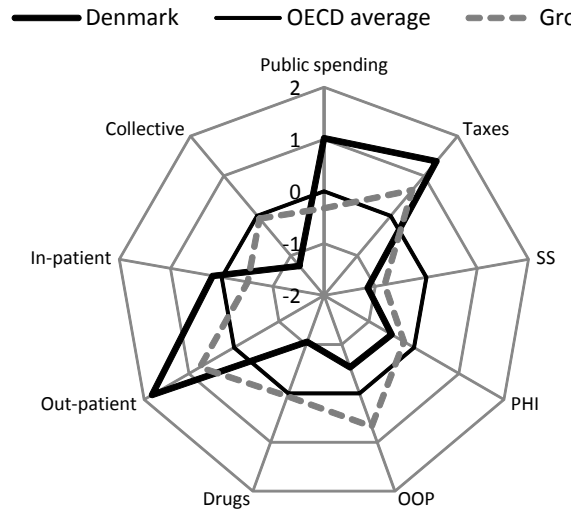

B. Amenable mortality by group of causes

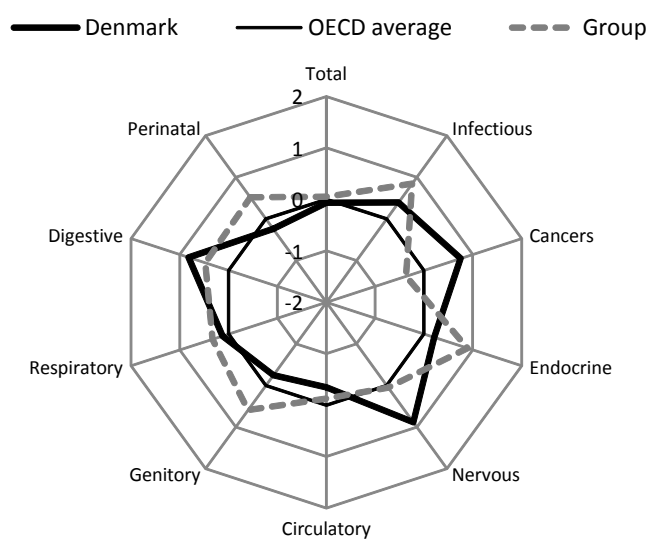

D. Activity and consumption

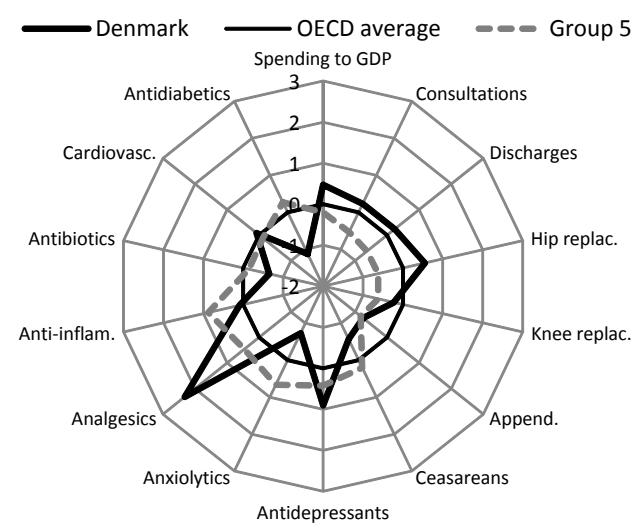

F. Policy and institutions

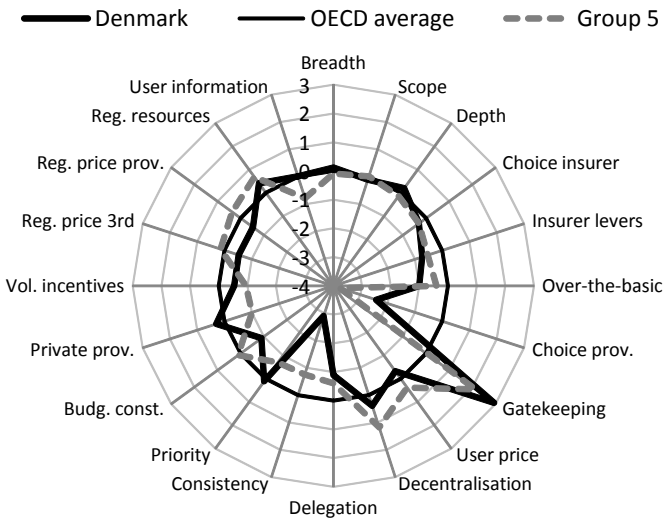

Note: Country groups have been determined by a cluster analysis performed on policy and institutional indicators. In all panels except Panel A, data points outside the average circle indicate that the level of the variable for the group or the country under scrutiny is higher than the average OECD country (e.g. Australia has more scanners than the OECD average country).

In Panel A, data points outside the average circle indicate that the group or the country under scrutiny performs better than the OECD average (e.g. administrative costs as a share of total health care spending are lower in Australia than on average in the OECD area). In all panels except Panel F, data represent the deviation from the OECD average and are expressed in number of standard deviations. In Panel $\mathrm{F}$, data shown are simple deviations from the OECD average.

Source: OECD Health Data 2009; OECD Survey on Health Systems Characteristics 2008-2009; Preliminary OECD work based on Nolte and Mc Kee (2008) 
Finland: health care indicators

Group 5: Denmark, Finland, Mexico, Portugal, Spain

A. Efficiency and quality

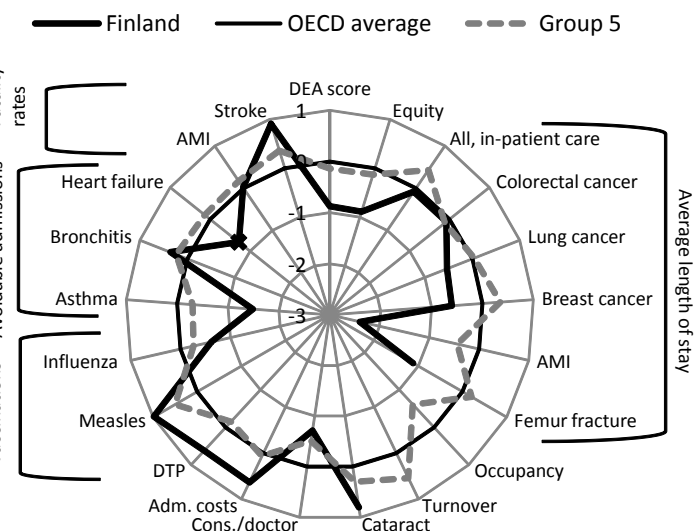

C. Prices and physical resources

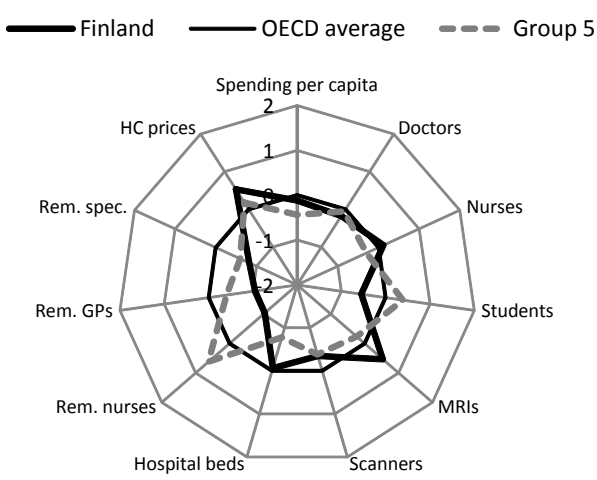

E. Financing and spending mix

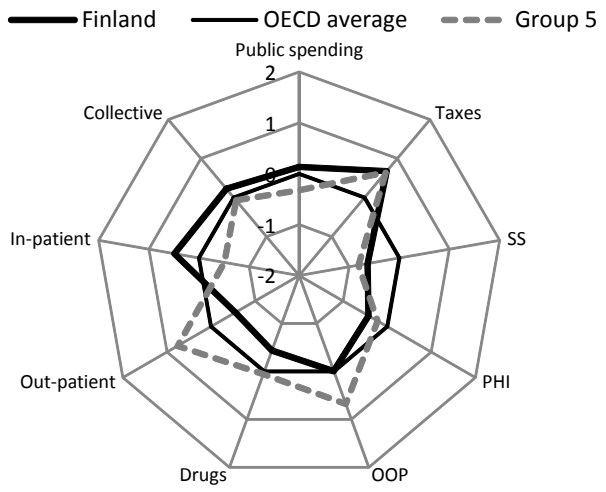

B. Amenable mortality by group of causes
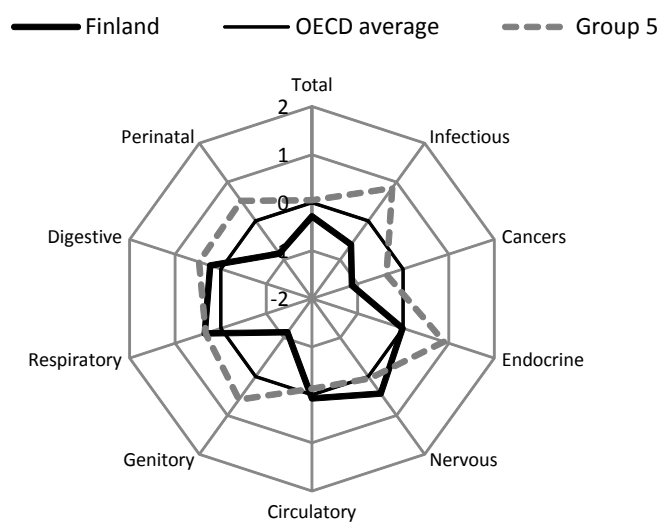

D. Activity and consumption

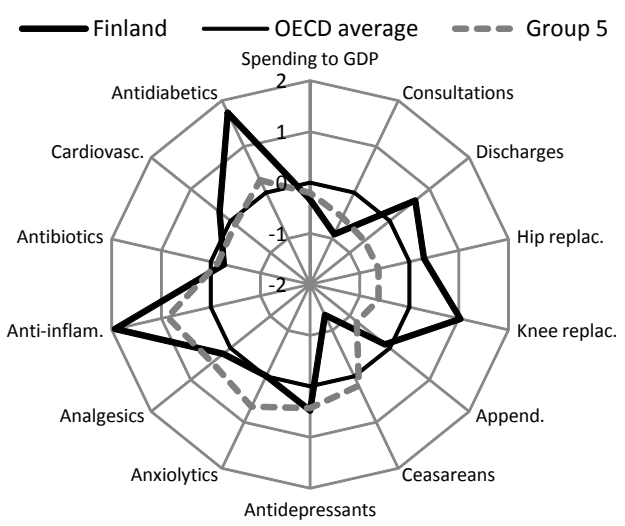

F. Policy and institutions

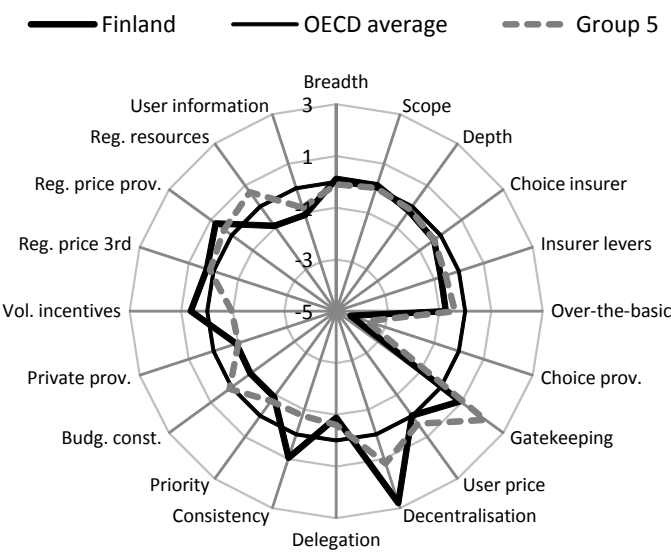

Note: Country groups have been determined by a cluster analysis performed on policy and institutional indicators. In all panels except Panel A data points outside the average circle indicate that the level of the variable for the group or the country under scrutiny is higher than the average OECD country (e.g. Australia has more scanners than the OECD average country).

In Panel A, data points outside the average circle indicate that the group or the country under scrutiny performs better than the OECD average (e.g. administrative costs as a share of total health care spending are lower in Australia than on average in the OECD area). In all panels except Panel F, data represent the deviation from the OECD average and are expressed in number of standard deviations. In Panel $\mathrm{F}$, data shown are simple deviations from the OECD average.

Source: OECD Health Data 2009; OECD Survey on Health Systems Characteristics 2008-2009; Preliminary OECD work based on Nolte and Mc Kee (2008) 
ECO/WKP(2010)25

France: health care indicators

Group 2: Australia, Belgium, Canada, France

A. Efficiency and quality

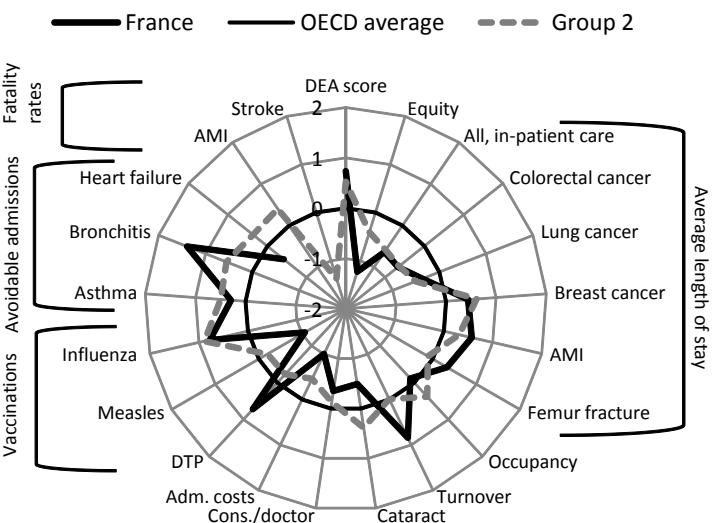

C. Prices and physical resources

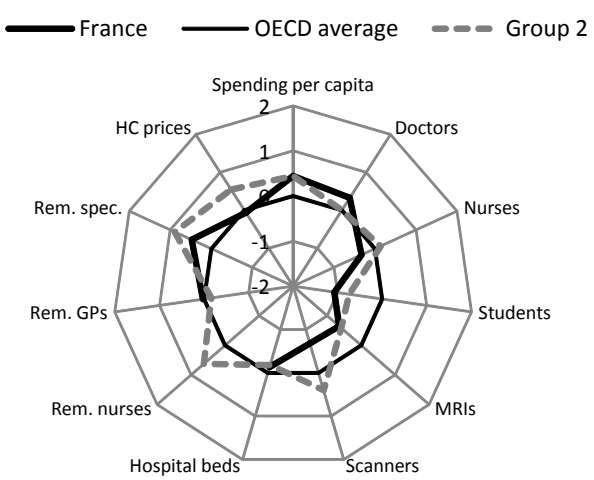

E. Financing and spending mix

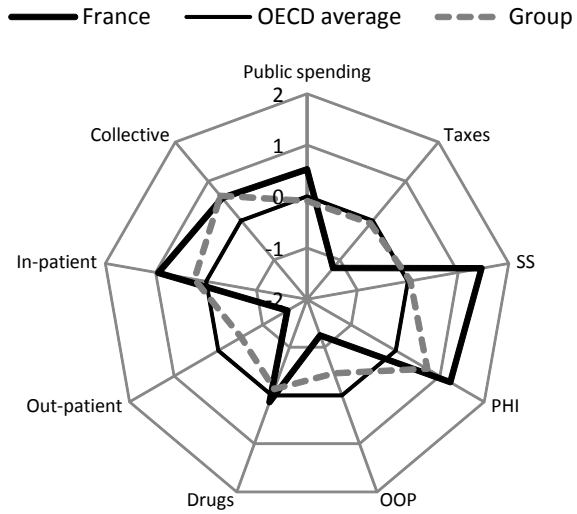

B. Amenable mortality by group of causes

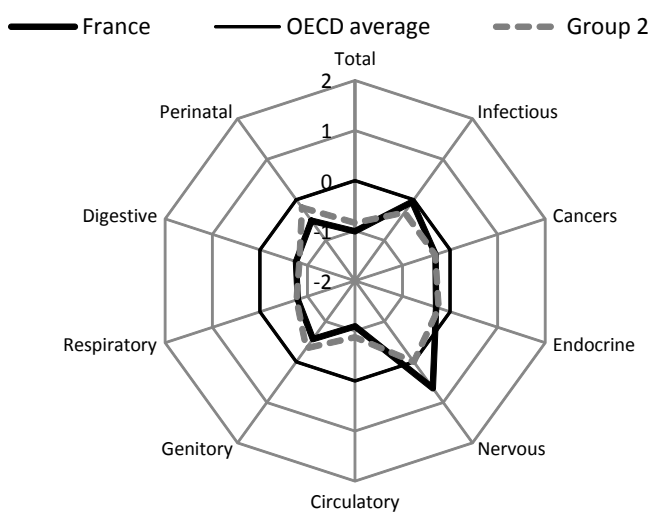

D. Activity and consumption

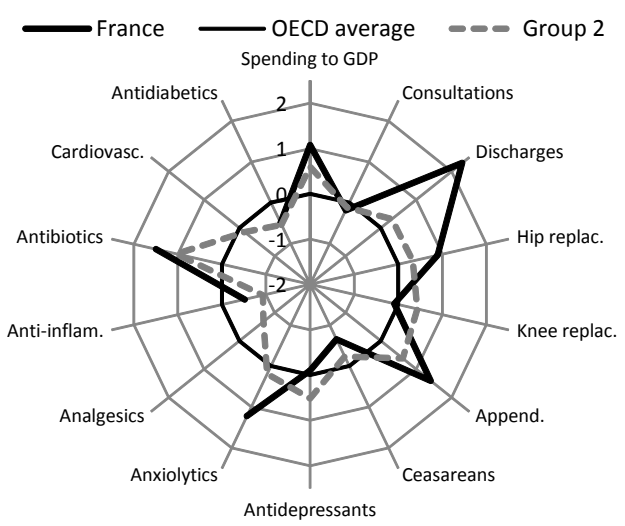

F. Policy and institutions

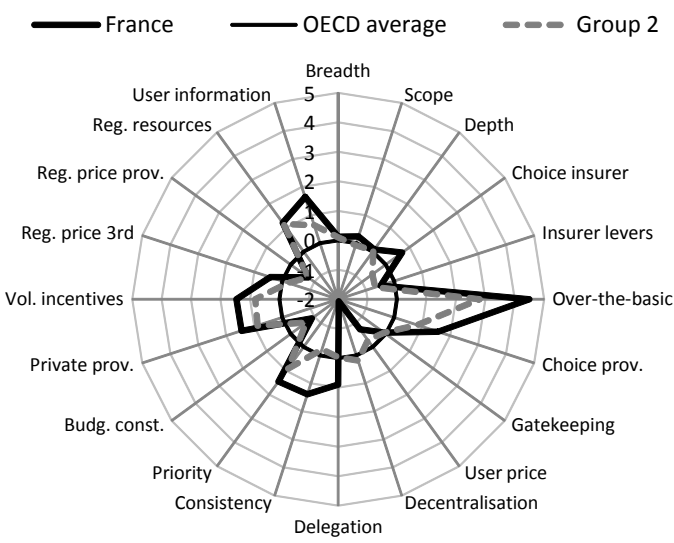

Note: Country groups have been determined by a cluster analysis performed on policy and institutional indicators. In all panels except Panel A, data points outside the average circle indicate that the level of the variable for the group or the country under scrutiny is higher than the average OECD country (e.g. Australia has more scanners than the OECD average country).

In Panel A, data points outside the average circle indicate that the group or the country under scrutiny performs better than the OECD average (e.g. administrative costs as a share of total health care spending are lower in Australia than on average in the OECD area). In all panels except Panel F, data represent the deviation from the OECD average and are expressed in number of standard deviations. In Panel $\mathrm{F}$, data shown are simple deviations from the OECD average.

Source: OECD Health Data 2009; OECD Survey on Health Systems Characteristics 2008-2009; Preliminary OECD work based on Nolte and Mc Kee (2008) 


\section{Germany: health care indicators}

Group 1: Germany, Netherlands, Slovak Republic, Switzerland

A. Efficiency and quality

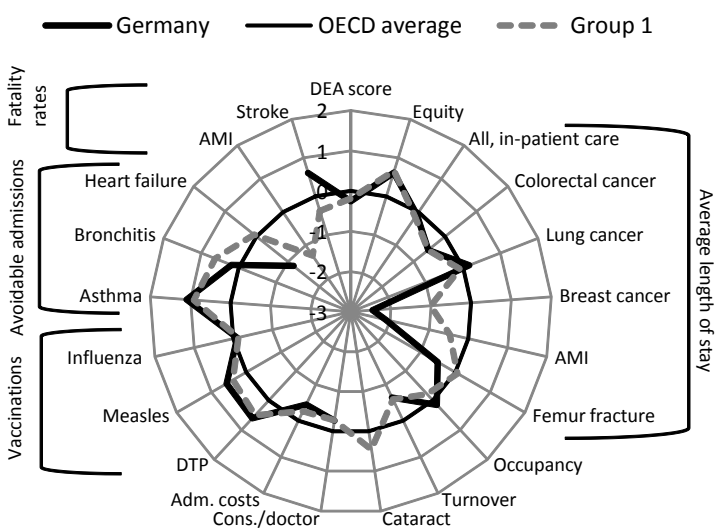

C. Prices and physical resources

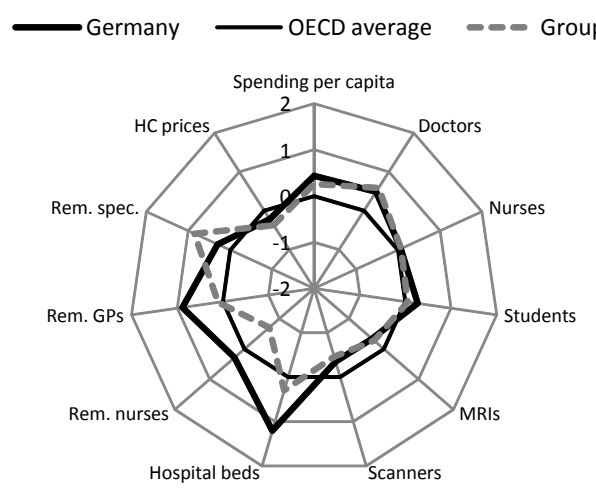

E. Financing and spending mix

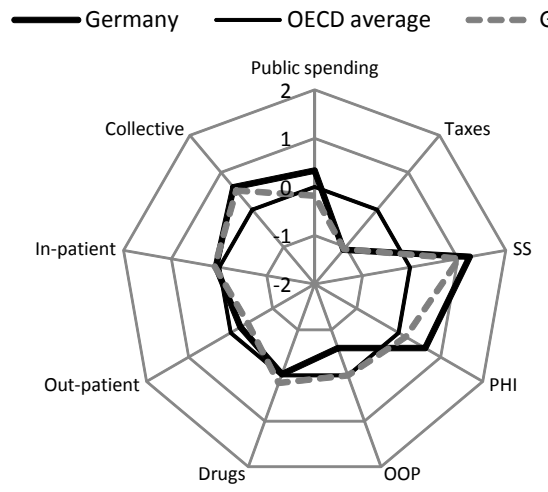

B. Amenable mortality by group of causes

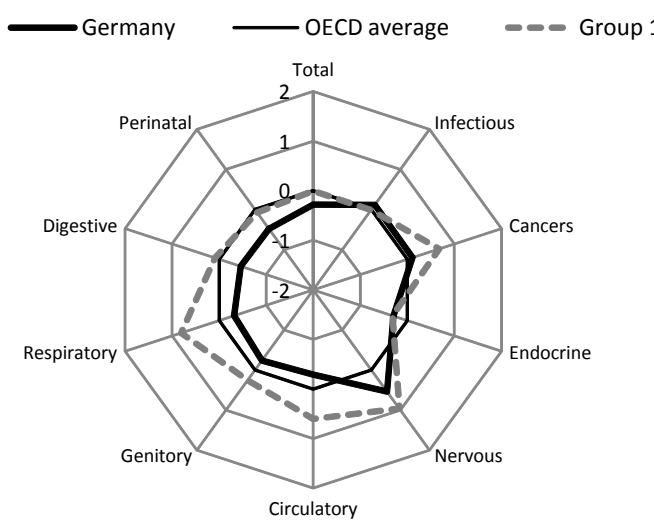

D. Activity and consumption

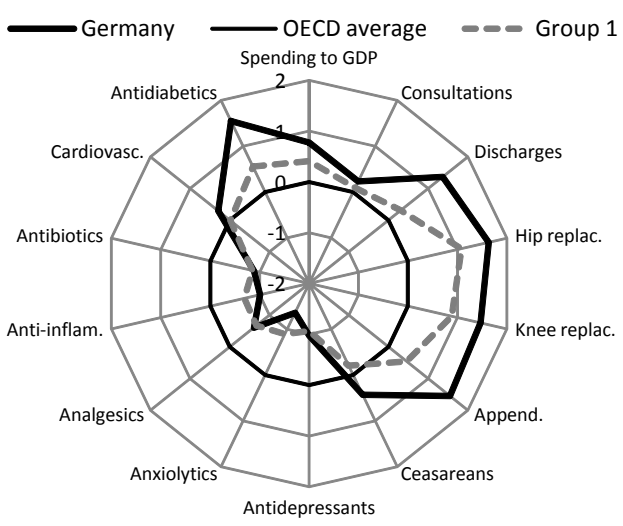

F. Policy and institutions

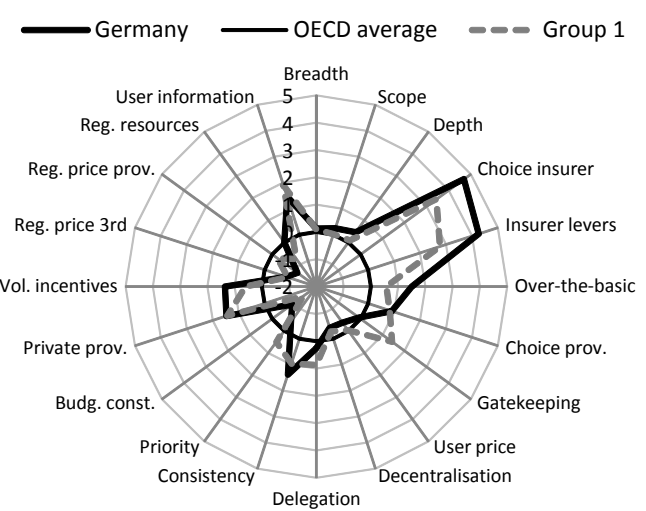

Note: Country groups have been determined by a cluster analysis performed on policy and institutional indicators. In all panels except Panel A, data points outside the average circle indicate that the level of the variable for the group or the country under scrutiny is higher than the average OECD country (e.g. Australia has more scanners than the OECD average country).

In Panel A, data points outside the average circle indicate that the group or the country under scrutiny performs better than the OECD average (e.g. administrative costs as a share of total health care spending are lower in Australia than on average in the OECD area). In all panels except Panel F, data represent the deviation from the OECD average and are expressed in number of standard deviations. In Panel $\mathrm{F}$, data shown are simple deviations from the OECD average.

Source: OECD Health Data 2009; OECD Survey on Health Systems Characteristics 2008-2009; Preliminary OECD work based on Nolte and Mc Kee (2008) 
$\mathrm{ECO} / \mathrm{WKP}(2010) 25$

\section{Greece: health care indicators}

Group 3: Austria, Czech Republic, Greece, Japan, Korea, Luxembourg

A. Efficiency and quality

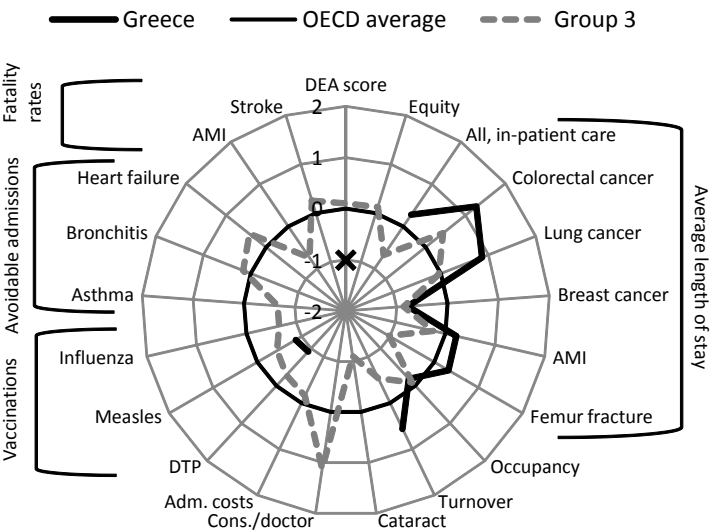

C. Prices and physical resources

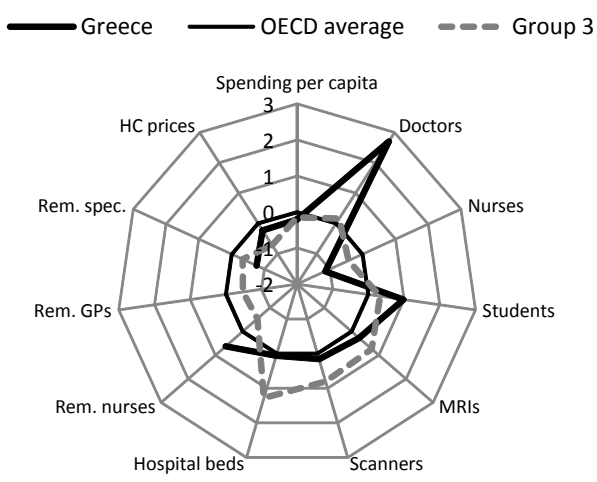

E. Financing and spending mix

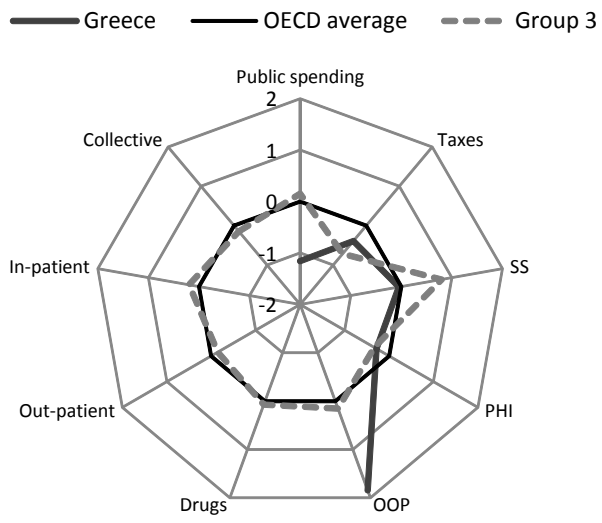

B. Amenable mortality by group of causes

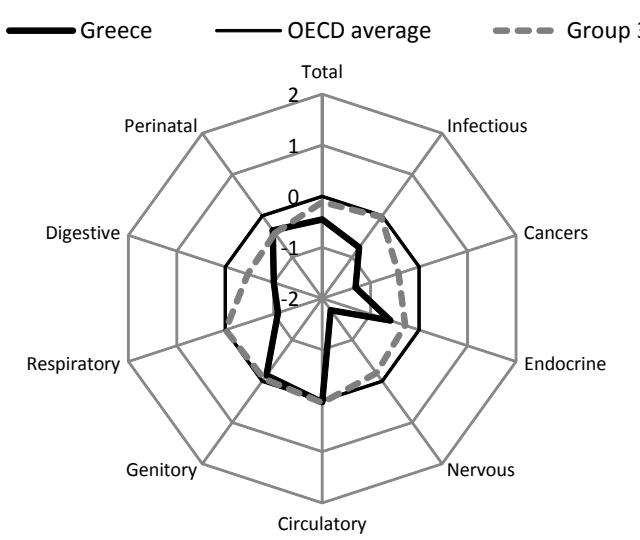

D. Activity and consumption

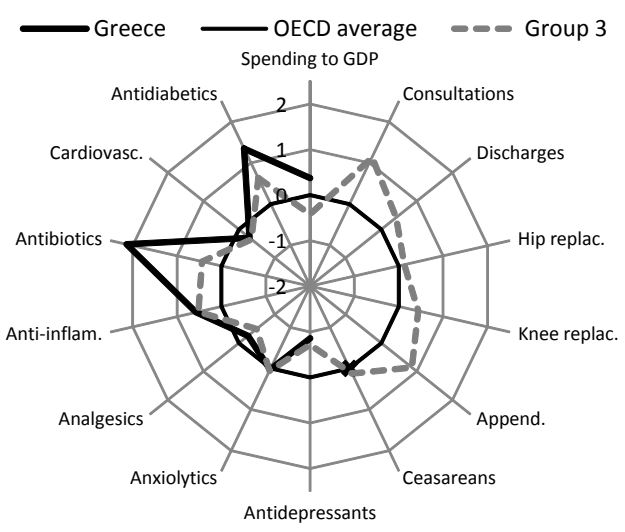

F. Policy and institutions

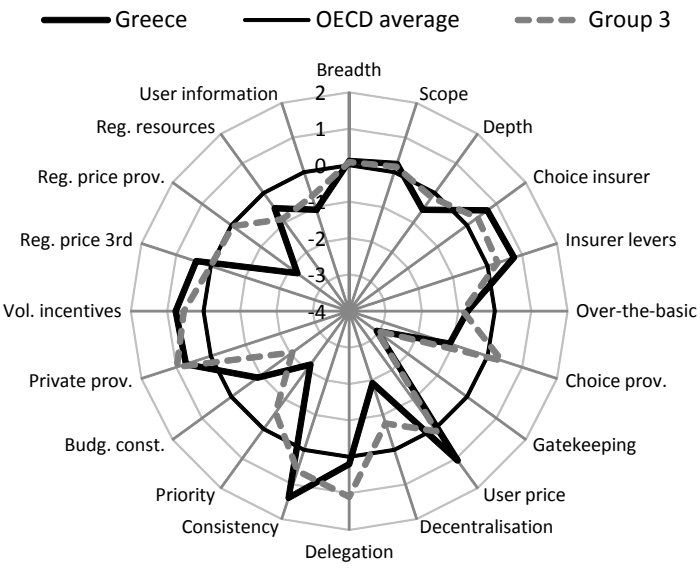

Note: Country groups have been determined by a cluster analysis performed on policy and institutional indicators. In all panels except Panel A, data points outside the average circle indicate that the level of the variable for the group or the country under scrutiny is higher than the average OECD country (e.g. Australia has more scanners than the OECD average country).

In Panel A, data points outside the average circle indicate that the group or the country under scrutiny performs better than the OECD average (e.g. administrative costs as a share of total health care spending are lower in Australia than on average in the OECD area). In all panels except Panel F, data represent the deviation from the OECD average and are expressed in number of standard deviations. In Panel $\mathrm{F}$, data shown are simple deviations from the OECD average.

Source: OECD Health Data 2009; OECD Survey on Health Systems Characteristics 2008-2009; Preliminary OECD work based on Nolte and Mc Kee (2008). 
Hungary: health care indicators

Group 6: Hungary, Ireland, Italy, New Zealand, Norway, Poland, United Kingdom

A. Efficiency and quality

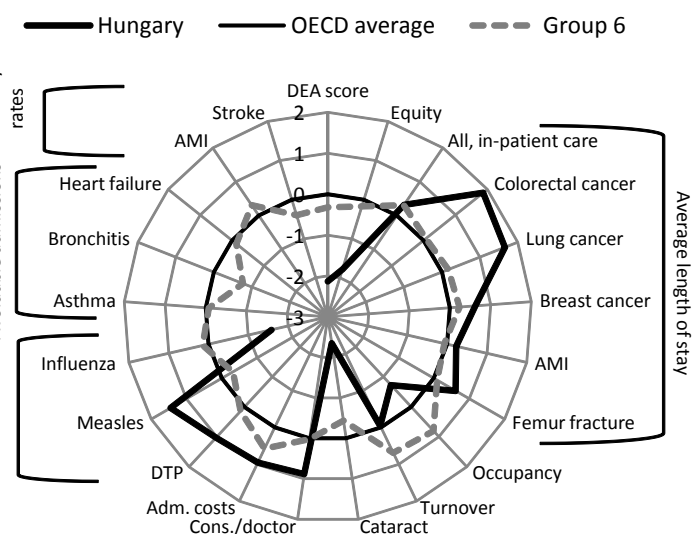

C. Prices and physical resources

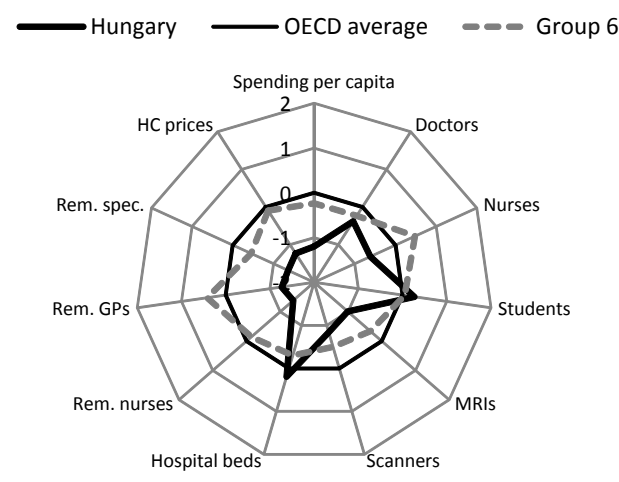

E. Financing and spending mix

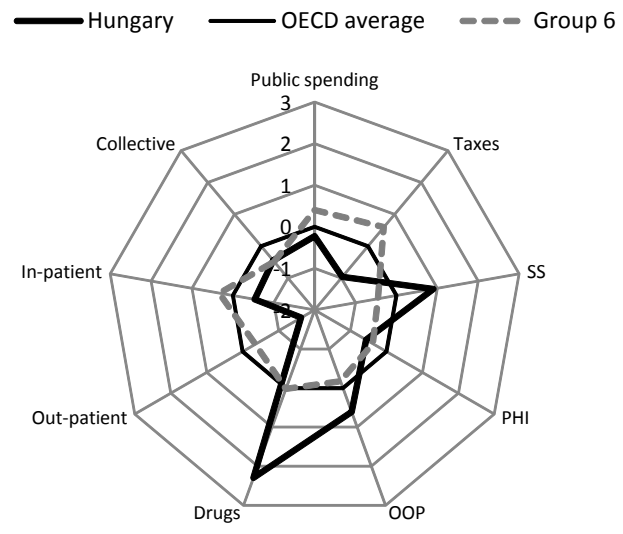

B. Amenable mortality by group of causes

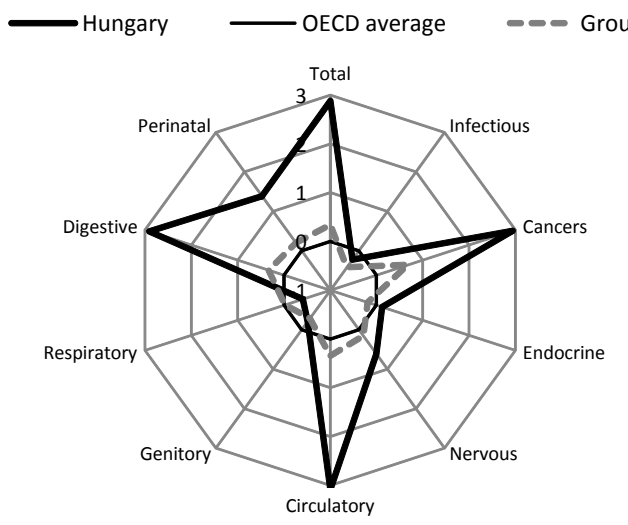

D. Activity and consumption

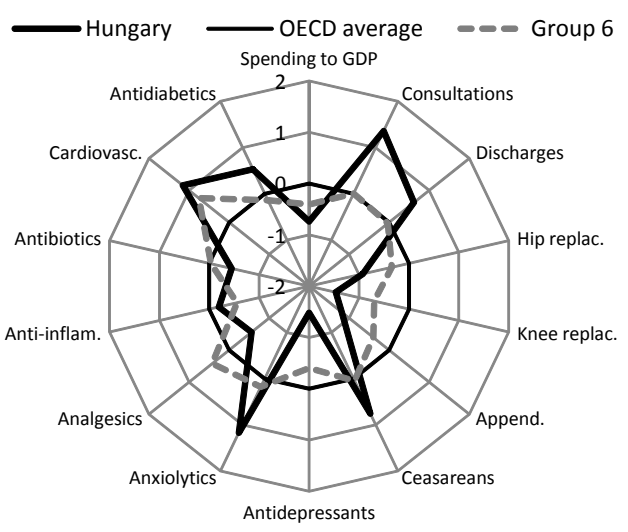

F. Policy and institutions

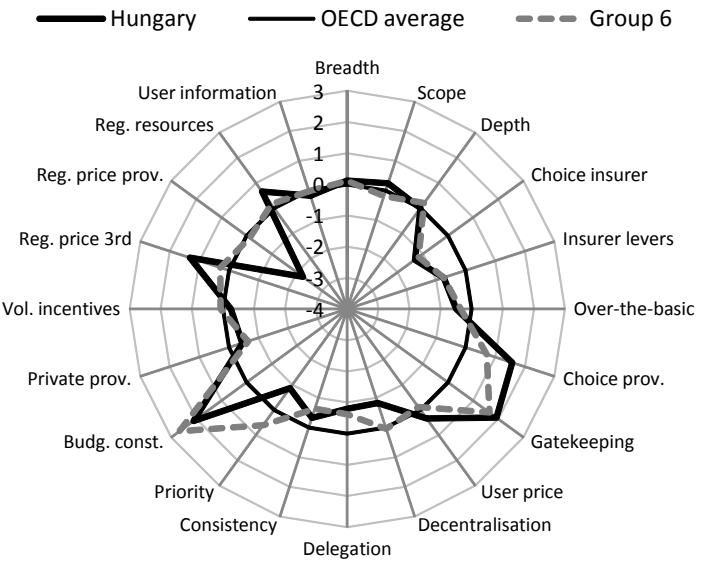

Note: Country groups have been determined by a cluster analysis performed on policy and institutional indicators. In all panels except Panel A, data points outside the average circle indicate that the level of the variable for the group or the country under scrutiny is higher than the average OECD country (e.g. Australia has more scanners than the OECD average country).

In Panel A, data points outside the average circle indicate that the group or the country under scrutiny performs better than the OECD average (e.g. administrative costs as a share of total health care spending are lower in Australia than on average in the OECD area). In all panels except Panel F, data represent the deviation from the OECD average and are expressed in number of standard deviations. In Panel $\mathrm{F}$, data shown are simple deviations from the OECD average.

Source: OECD Health Data 2009; OECD Survey on Health Systems Characteristics 2008-2009; Preliminary OECD work based on Nolte and Mc Kee (2008) 
ECO/WKP(2010)25

\section{Iceland: health care indicators}

Group 4: Iceland, Sweden, Turkey

A. Efficiency and quality

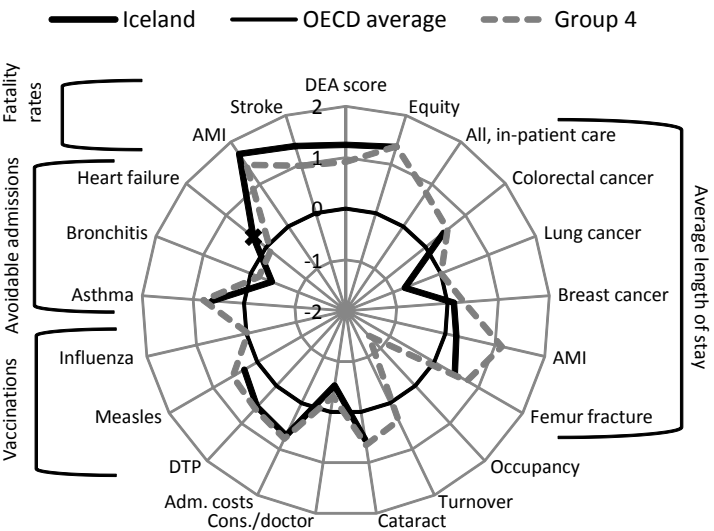

C. Prices and physical resources

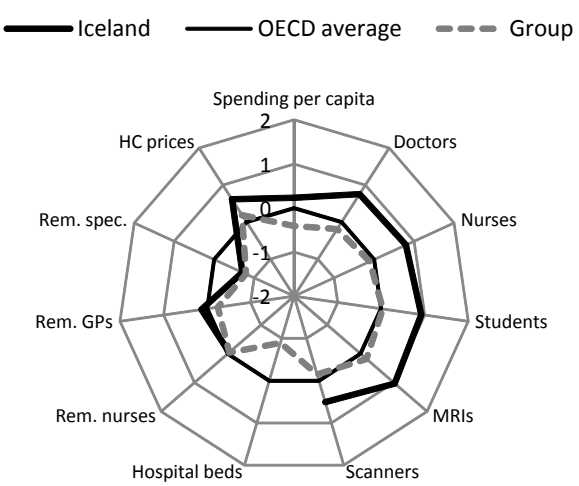

E. Financing and spending mix

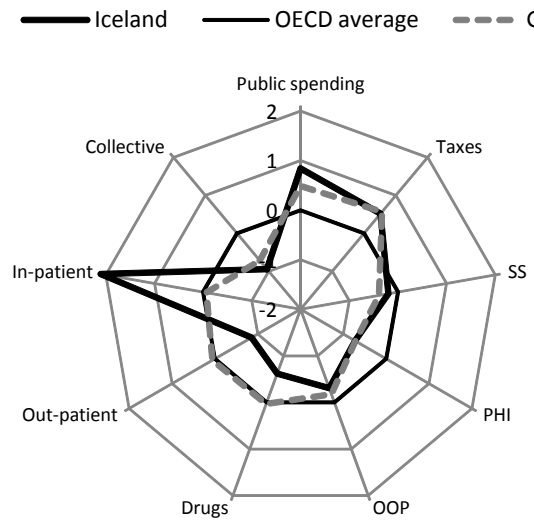

B. Amenable mortality by group of causes

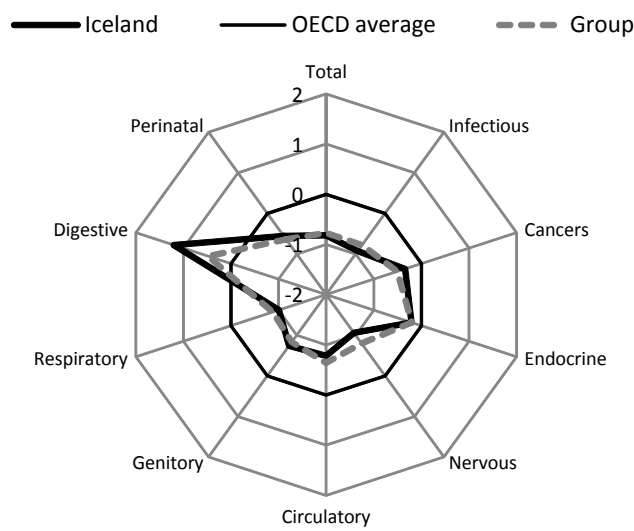

D. Activity and consumption

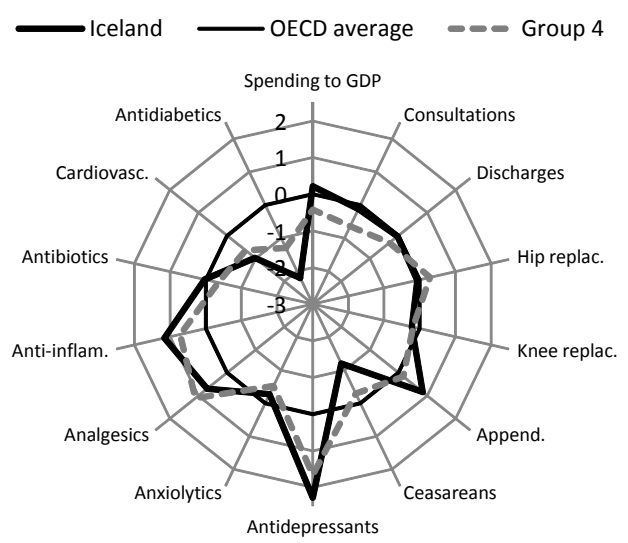

F. Policy and institutions

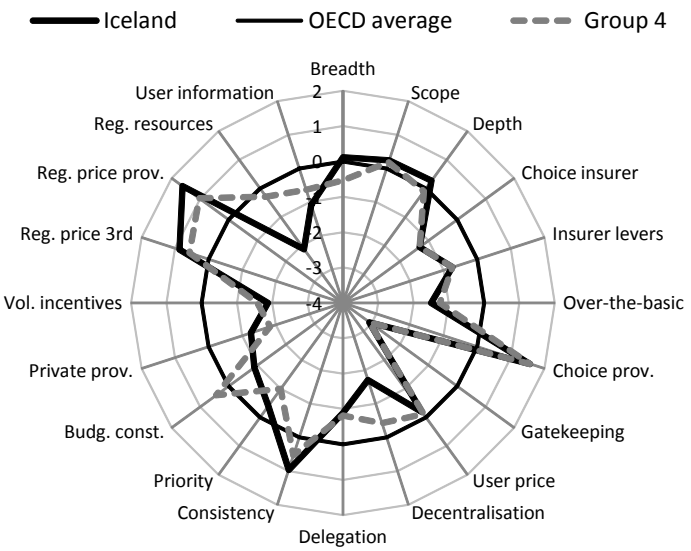

Note: Country groups have been determined by a cluster analysis performed on policy and institutional indicators. In all panels except Panel A, data points outside the average circle indicate that the level of the variable for the group or the country under scrutiny is higher than the average OECD country (e.g. Australia has more scanners than the OECD average country).

In Panel A, data points outside the average circle indicate that the group or the country under scrutiny performs better than the OECD average (e.g. administrative costs as a share of total health care spending are lower in Australia than on average in the OECD area). In all panels except Panel F, data represent the deviation from the OECD average and are expressed in number of standard deviations. In Panel $\mathrm{F}$, data shown are simple deviations from the OECD average.

Source: OECD Health Data 2009; OECD Survey on Health Systems Characteristics 2008-2009; Preliminary OECD work based on Nolte and Mc Kee (2008). 


\section{Ireland: health care indicators}

Group 6: Hungary, Ireland, Italy, New Zealand, Norway, Poland, United Kingdom

A. Efficiency and quality

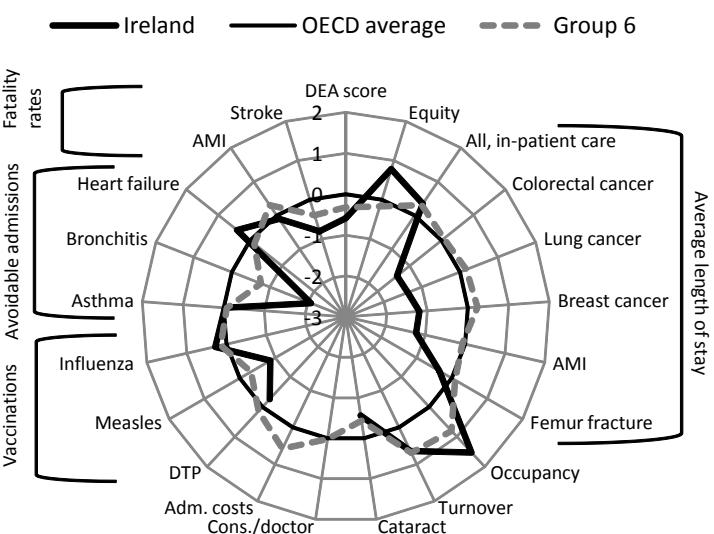

C. Prices and physical resources

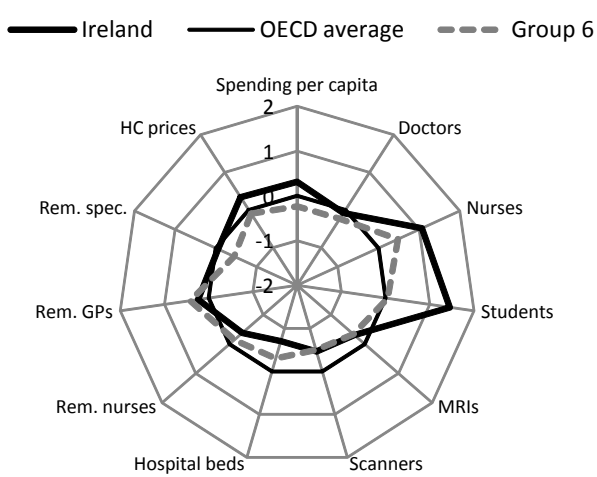

E. Financing and spending mix

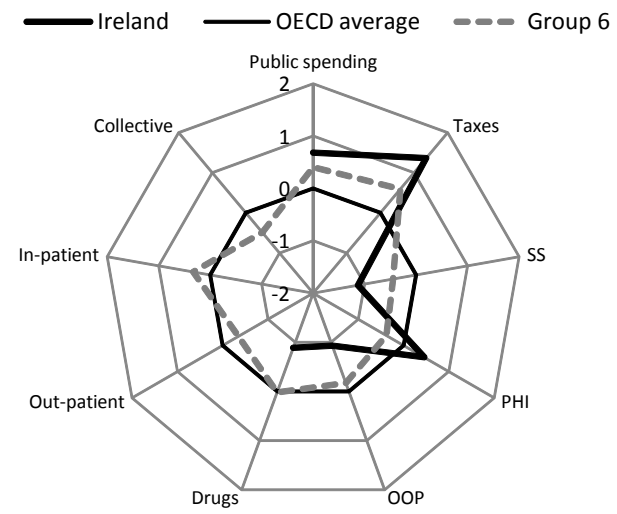

B. Amenable mortality by group of causes

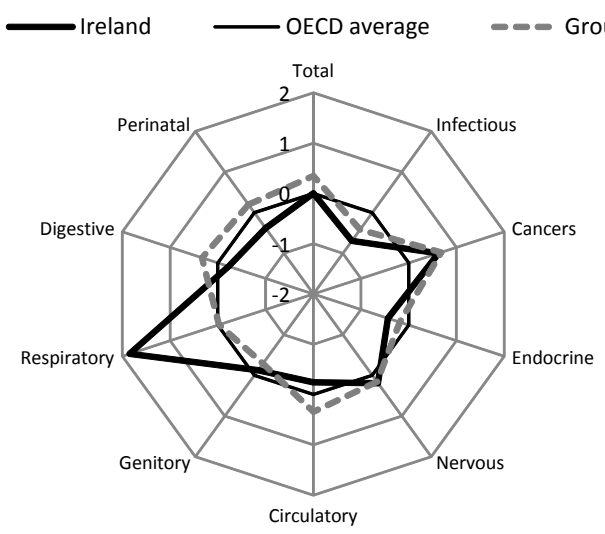

D. Activity and consumption

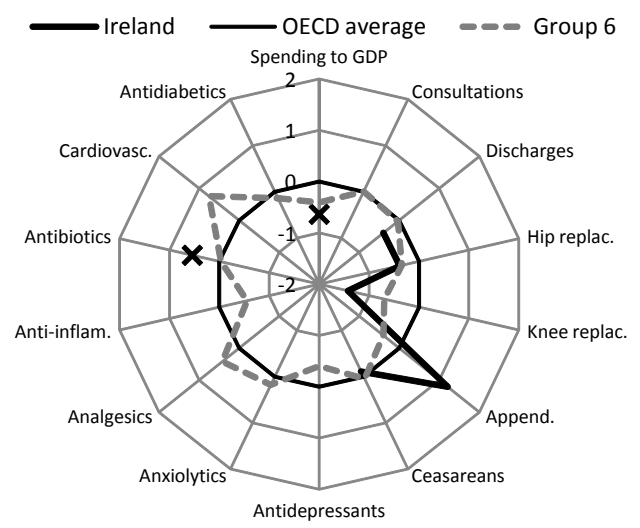

F. Policy and institutions

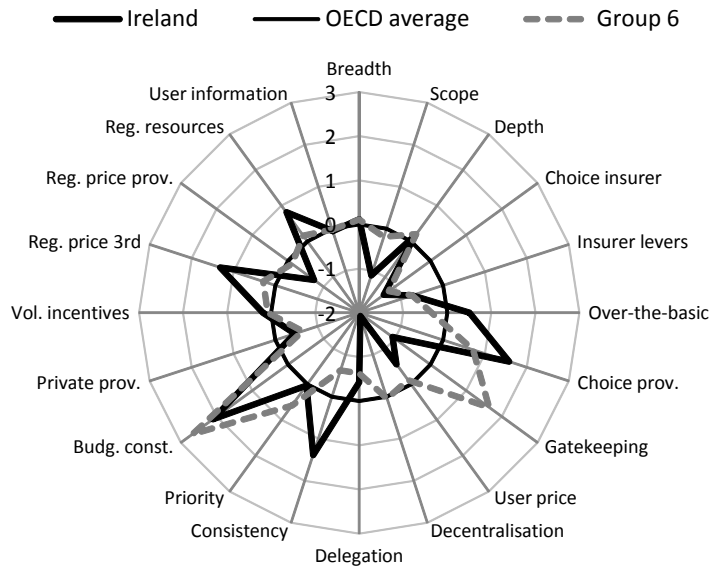

Note: Country groups have been determined by a cluster analysis performed on policy and institutional indicators. In all panels except Panel A, data points outside the average circle indicate that the level of the variable for the group or the country under scrutiny is higher than the average OECD country (e.g. Australia has more scanners than the OECD average country).

In Panel A, data points outside the average circle indicate that the group or the country under scrutiny performs better than the OECD average (e.g. administrative costs as a share of total health care spending are lower in Australia than on average in the OECD area). In all panels except Panel F, data represent the deviation from the OECD average and are expressed in number of standard deviations. In Panel $\mathrm{F}$, data shown are simple deviations from the OECD average.

Source: OECD Health Data 2009; OECD Survey on Health Systems Characteristics 2008-2009; Preliminary OECD work based on Nolte and Mc Kee (2008) 
ECO/WKP(2010)25

\section{Italy: health care indicators}

Group 6: Hungary, Ireland, Italy, New Zealand, Norway, Poland, United Kingdom

A. Efficiency and quality

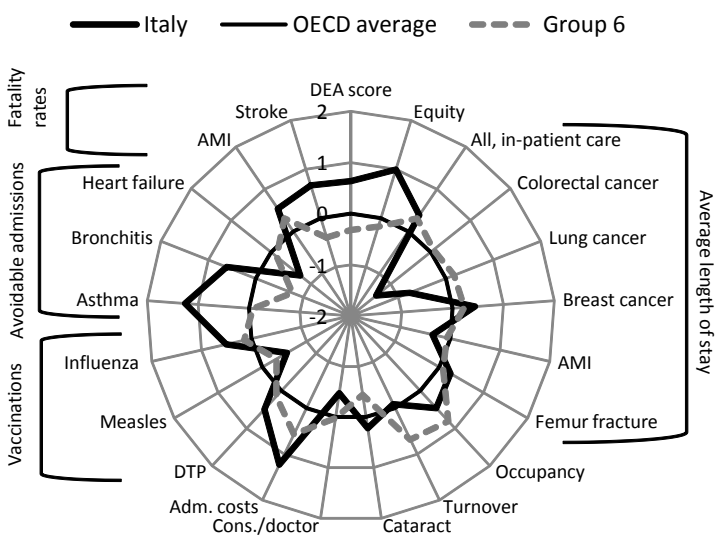

C. Prices and physical resources

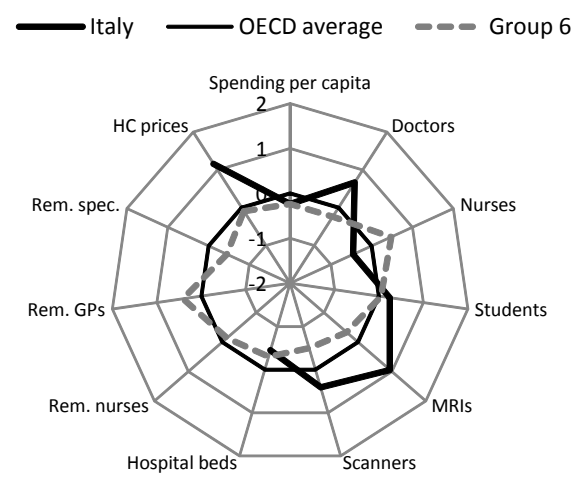

E. Financing and spending mix

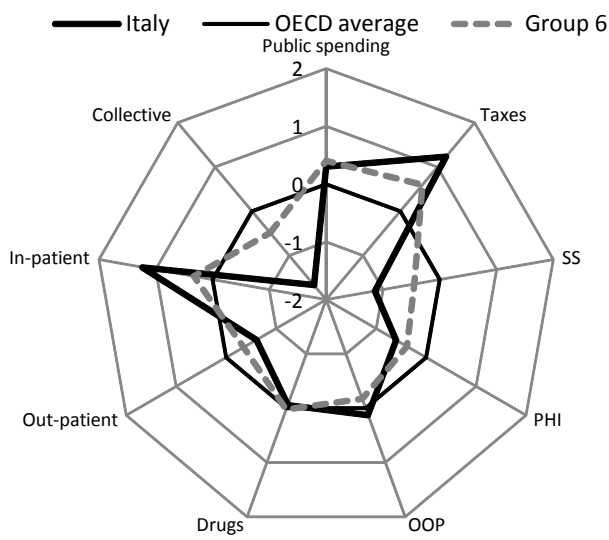

B. Amenable mortality by group of causes

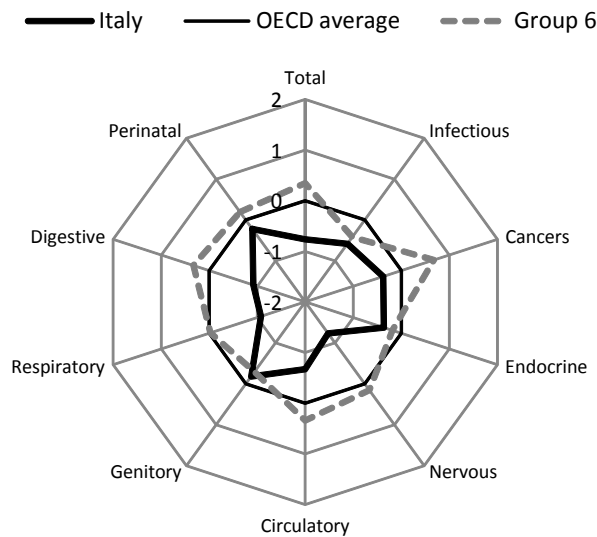

D. Activity and consumption

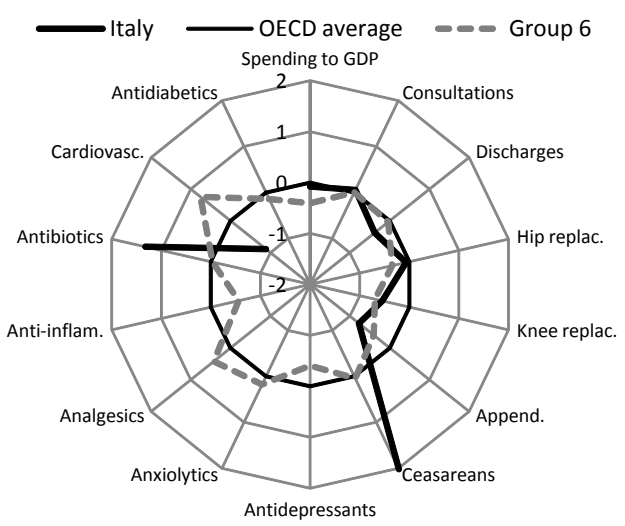

F. Policy and institutions

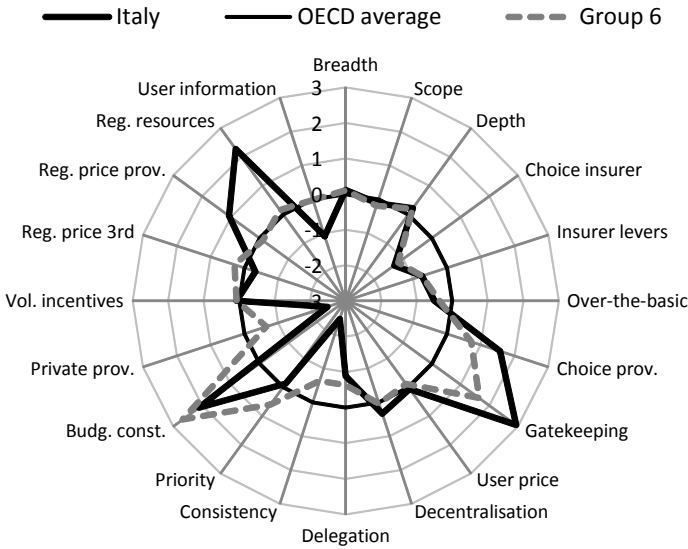

Note: Country groups have been determined by a cluster analysis performed on policy and institutional indicators. In all panels except Panel A, data points outside the average circle indicate that the level of the variable for the group or the country under scrutiny is higher than the average OECD country (e.g. Australia has more scanners than the OECD average country).

In Panel A, data points outside the average circle indicate that the group or the country under scrutiny performs better than the OECD average (e.g. administrative costs as a share of total health care spending are lower in Australia than on average in the OECD area). In all panels except Panel F, data represent the deviation from the OECD average and are expressed in number of standard deviations. In Panel $\mathrm{F}$, data shown are simple deviations from the OECD average.

Source: OECD Health Data 2009; OECD Survey on Health Systems Characteristics 2008-2009; Preliminary OECD work based on Nolte and Mc Kee (2008) 
Japan: health care indicators

Group 3: Austria, Czech Republic, Greece, Japan, Korea, Luxembourg

A. Efficiency and quality

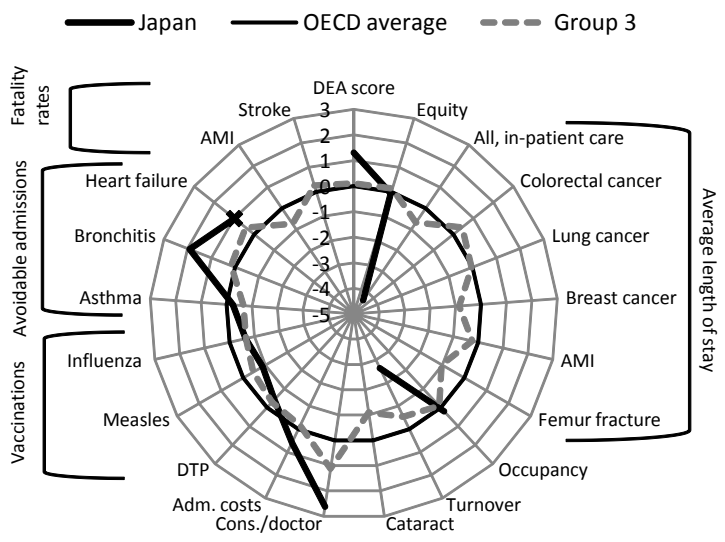

C. Prices and physical resources

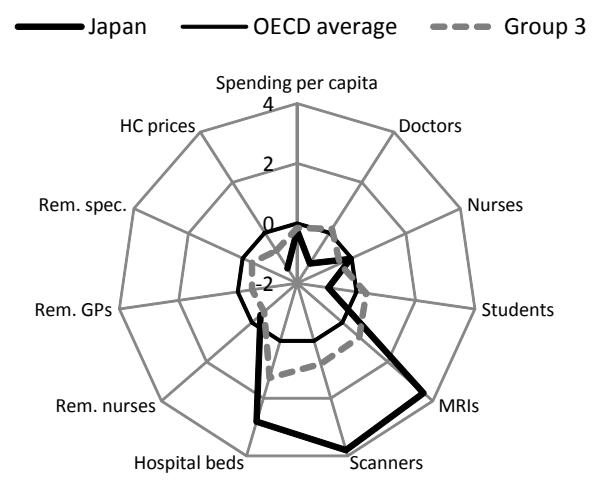

E. Financing and spending mix

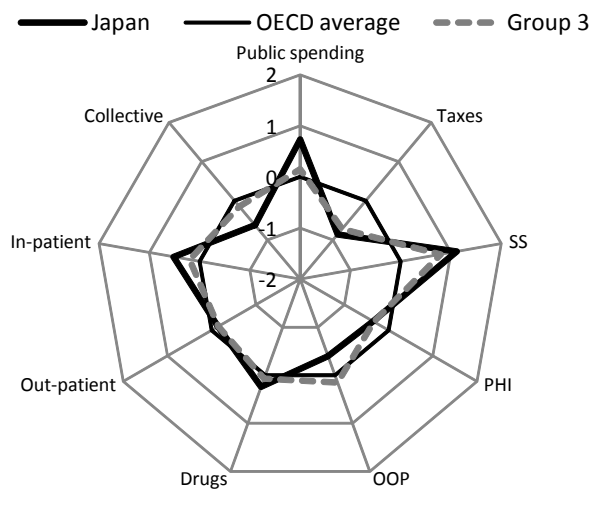

B. Amenable mortality by group of causes

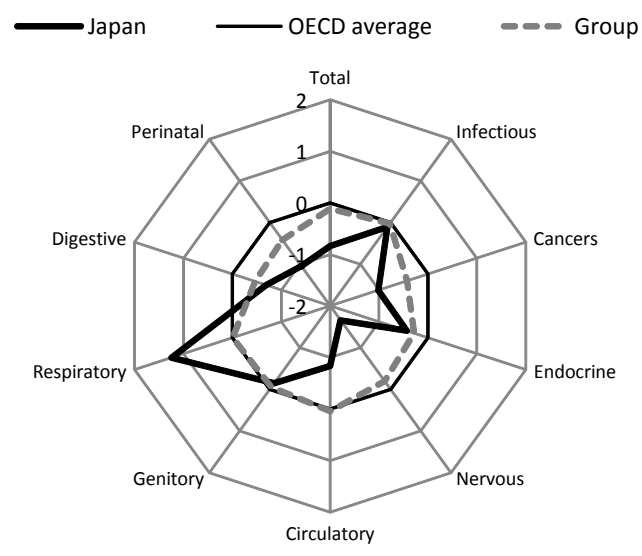

D. Activity and consumption

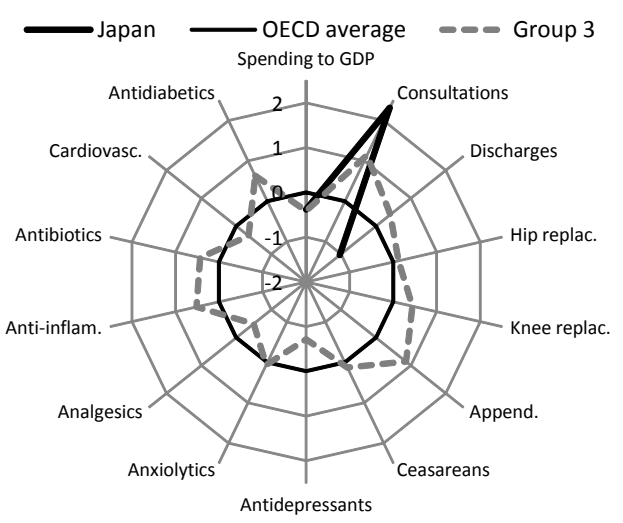

F. Policy and institutions

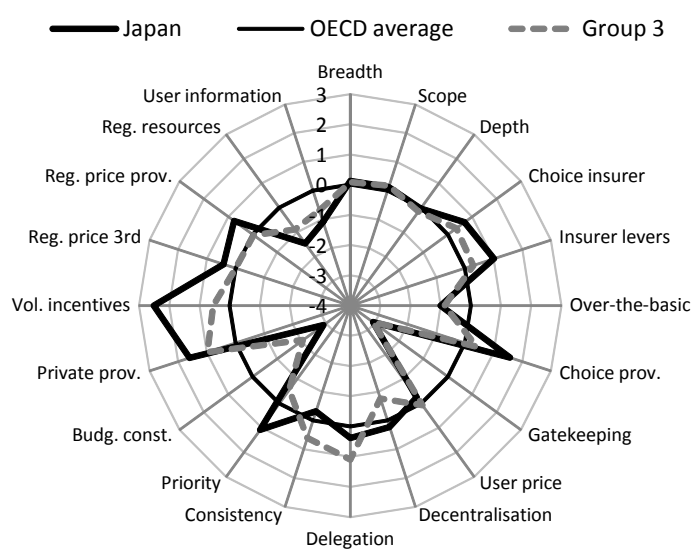

Note: Country groups have been determined by a cluster analysis performed on policy and institutional indicators. In all panels except Panel A, data points outside the average circle indicate that the level of the variable for the group or the country under scrutiny is higher than the average OECD country (e.g. Australia has more scanners than the OECD average country).

In Panel A, data points outside the average circle indicate that the group or the country under scrutiny performs better than the OECD average (e.g. administrative costs as a share of total health care spending are lower in Australia than on average in the OECD area). In all panels except Panel F, data represent the deviation from the OECD average and are expressed in number of standard deviations. In Panel $\mathrm{F}$, data shown are simple deviations from the OECD average.

Source: OECD Health Data 2009; OECD Survey on Health Systems Characteristics 2008-2009; Preliminary OECD work based on Nolte and Mc Kee (2008). 
ECO/WKP(2010)25

\section{Korea: health care indicators}

Group 3: Austria, Czech Republic, Greece, Japan, Korea, Luxembourg

A. Efficiency and quality

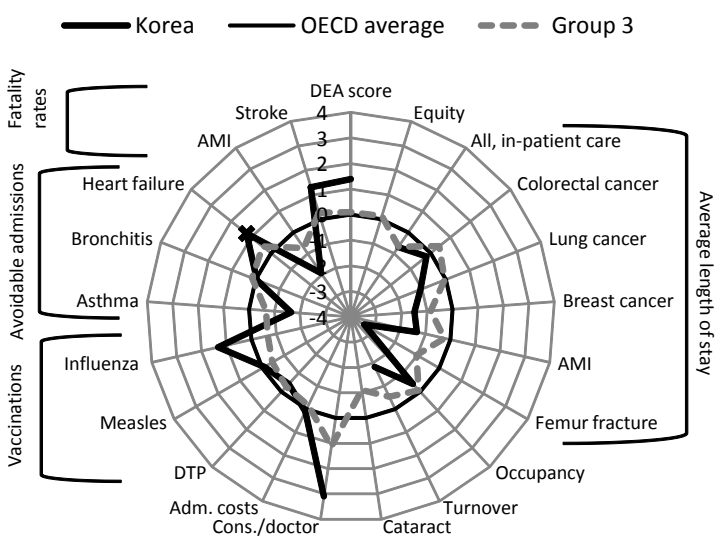

C. Prices and physical resources

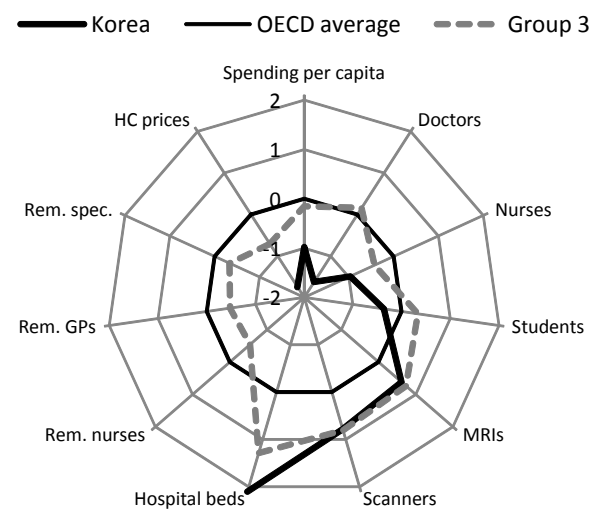

E. Financing and spending mix

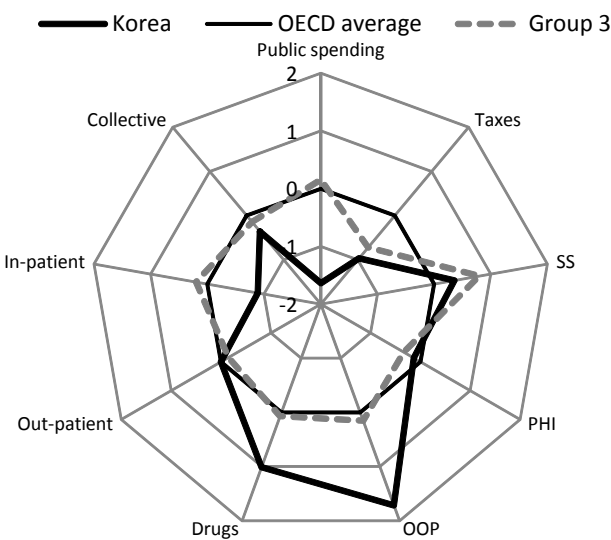

B. Amenable mortality by group of causes
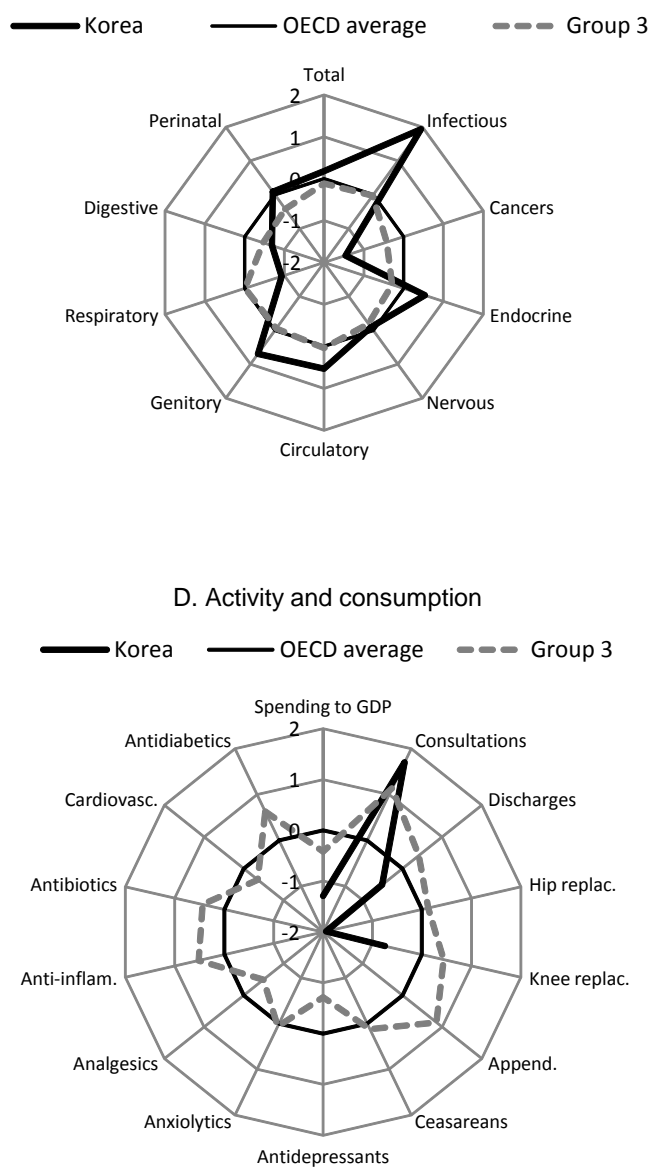

F. Policy and institutions

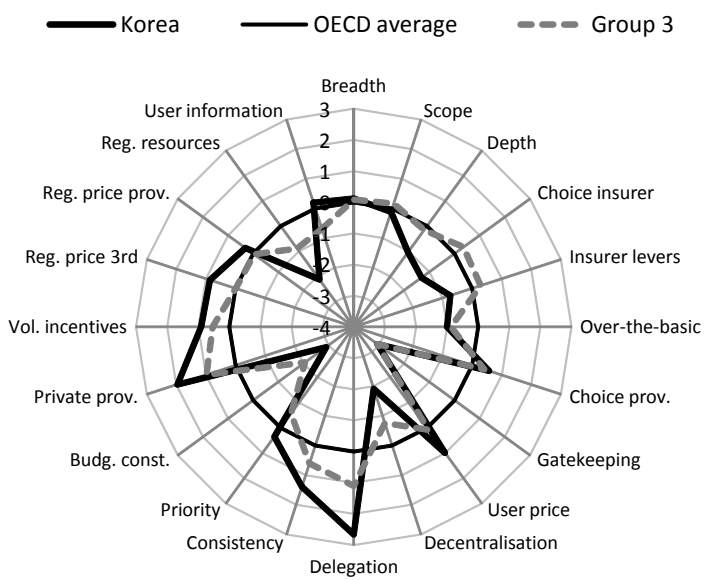

Note: Country groups have been determined by a cluster analysis performed on policy and institutional indicators. In all panels except Panel A, data points outside the average circle indicate that the level of the variable for the group or the country under scrutiny is higher than the average OECD country (e.g. Australia has more scanners than the OECD average country).

In Panel A, data points outside the average circle indicate that the group or the country under scrutiny performs better than the OECD average (e.g. administrative costs as a share of total health care spending are lower in Australia than on average in the OECD area). In all panels except Panel F, data represent the deviation from the OECD average and are expressed in number of standard deviations. In Panel $\mathrm{F}$, data shown are simple deviations from the OECD average.

Source: OECD Health Data 2009; OECD Survey on Health Systems Characteristics 2008-2009; Preliminary OECD work based on Nolte and Mc Kee (2008). 
Luxembourg: health care indicators

Group 3: Austria, Czech Republic, Greece, Japan, Korea, Luxembourg

A. Efficiency and quality

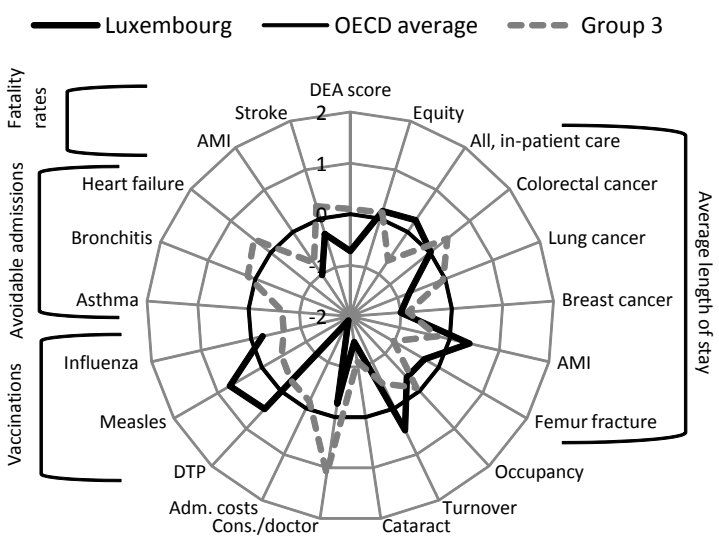

C. Prices and physical resources

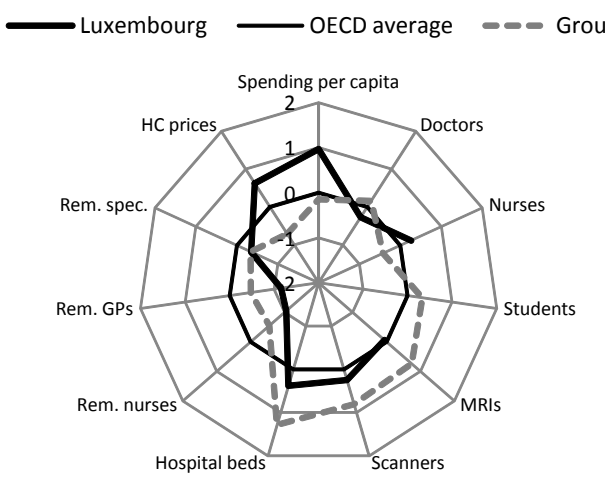

E. Financing and spending mix

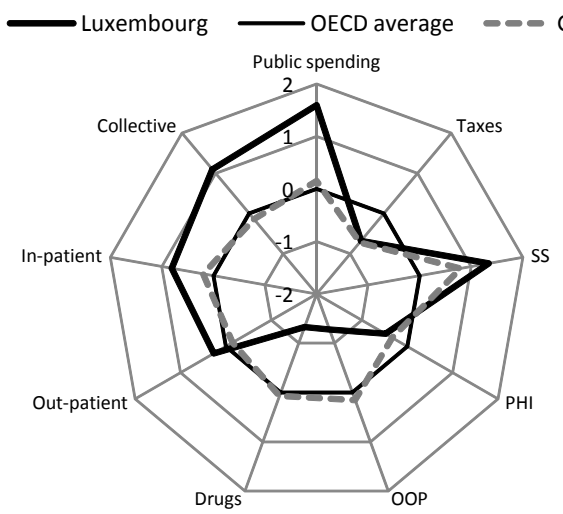

B. Amenable mortality by group of causes

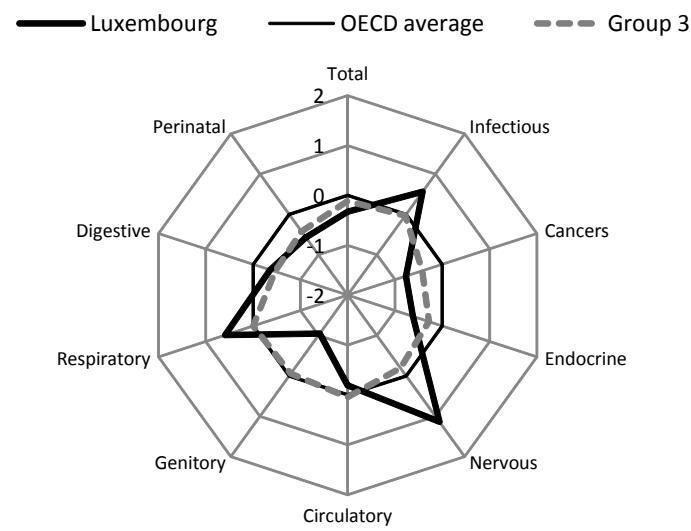

D. Activity and consumption

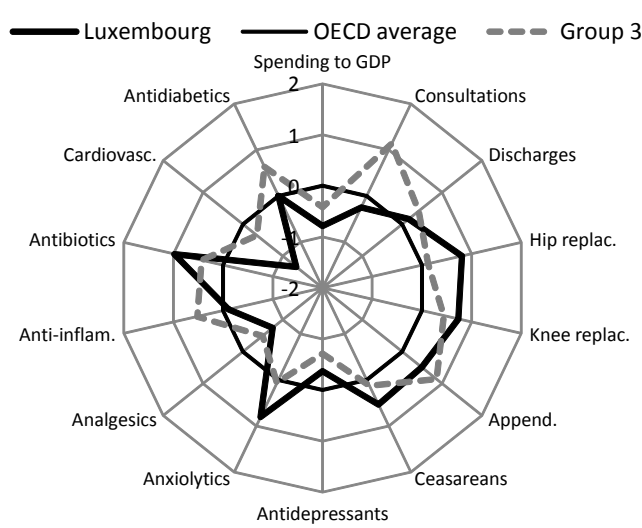

F. Policy and institutions

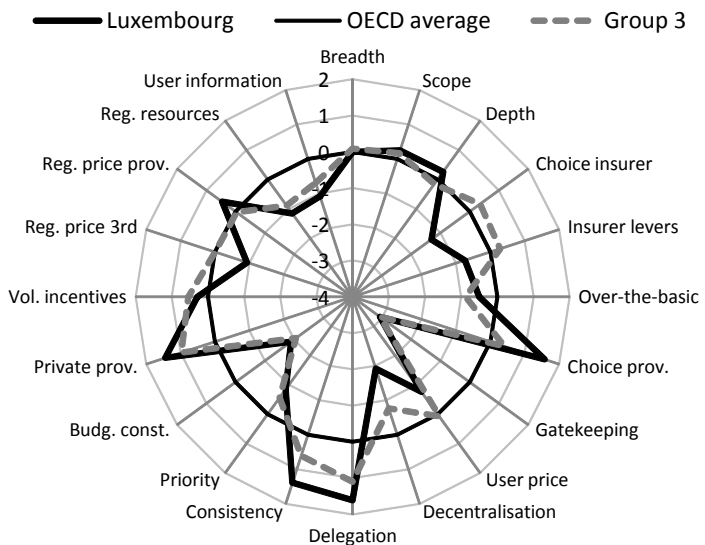

Note: Country groups have been determined by a cluster analysis performed on policy and institutional indicators. In all panels except Panel A, data points outside the average circle indicate that the level of the variable for the group or the country under scrutiny is higher than the average OECD country (e.g. Australia has more scanners than the OECD average country).

In Panel A, data points outside the average circle indicate that the group or the country under scrutiny performs better than the OECD average (e.g. administrative costs as a share of total health care spending are lower in Australia than on average in the OECD area).

In all panels except Panel F, data represent the deviation from the OECD average and are expressed in number of standard deviations. In Panel $F$, data shown are simple deviations from the OECD average.

Source: OECD Health Data 2009; OECD Survey on Health Systems Characteristics 2008-2009; Preliminary OECD work based on Nolte and Mc Kee (2008). 
ECO/WKP(2010)25

\section{Mexico: health care indicators}

Group 5: Denmark, Finland, Mexico, Portugal, Spain

A. Efficiency and quality

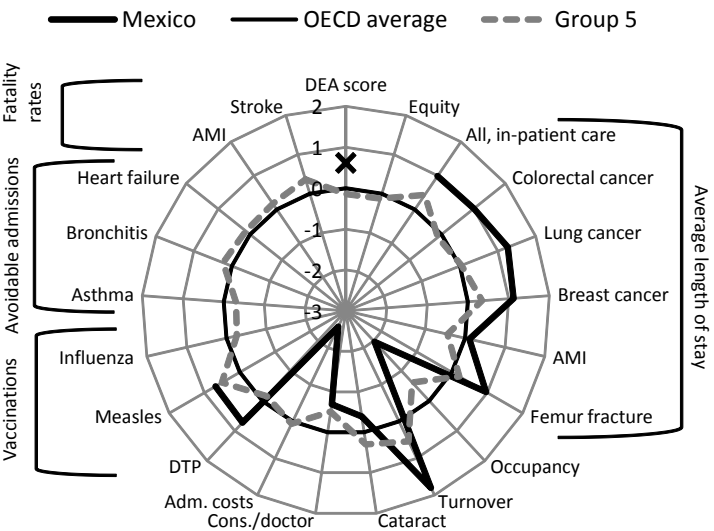

C. Prices and physical resources

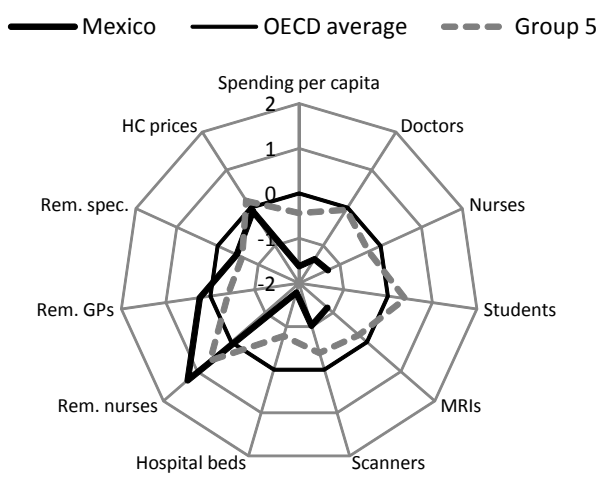

E. Financing and spending mix

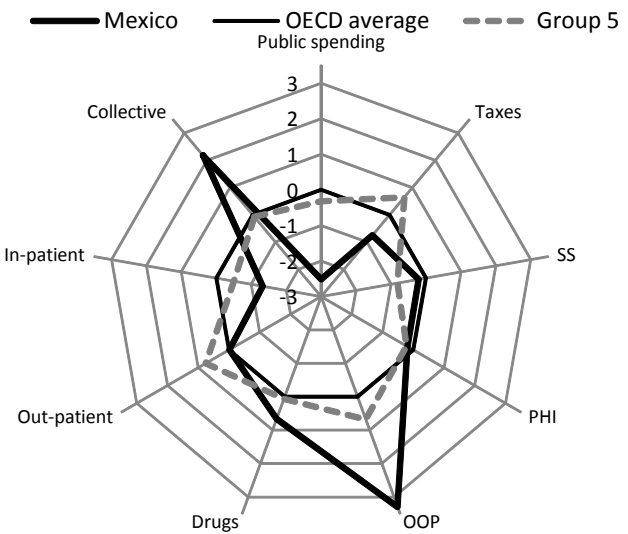

B. Amenable mortality by group of causes

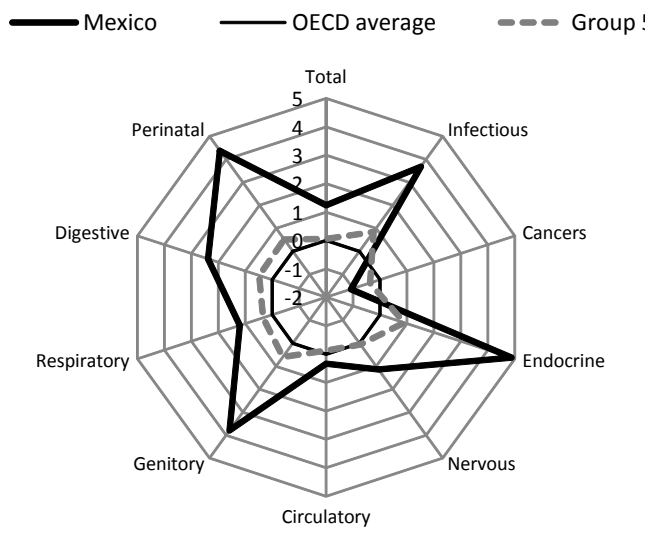

D. Activity and consumption

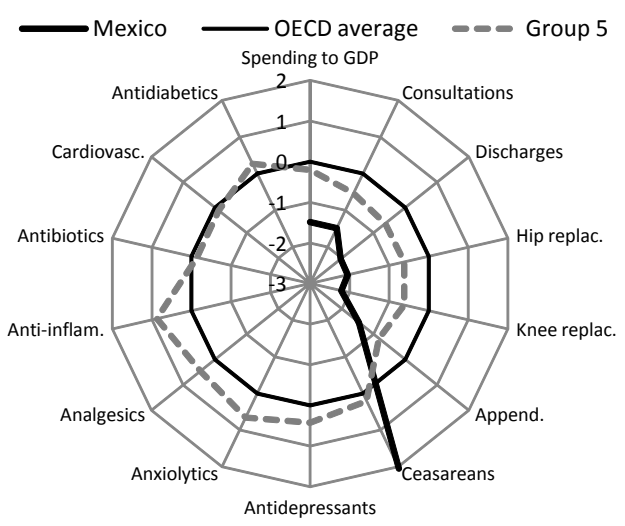

F. Policy and institutions

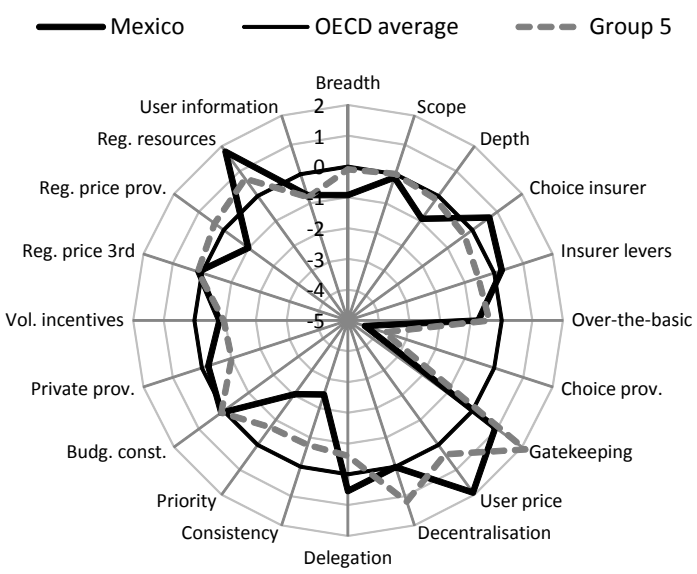

Note: Country groups have been determined by a cluster analysis performed on policy and institutional indicators. In all panels except Panel A, data points outside the average circle indicate that the level of the variable for the group or the country under scrutiny is higher than the average OECD country (e.g. Australia has more scanners than the OECD average country).

In Panel A, data points outside the average circle indicate that the group or the country under scrutiny performs better than the OECD average (e.g. administrative costs as a share of total health care spending are lower in Australia than on average in the OECD area). In all panels except Panel F, data represent the deviation from the OECD average and are expressed in number of standard deviations. In Panel $\mathrm{F}$, data shown are simple deviations from the OECD average.

Source: OECD Health Data 2009; OECD Survey on Health Systems Characteristics 2008-2009; Preliminary OECD work based on Nolte and Mc Kee (2008) 
Netherlands: health care indicators

Group 1: Germany, Netherlands, Slovak Republic, Switzerland

A. Efficiency and quality

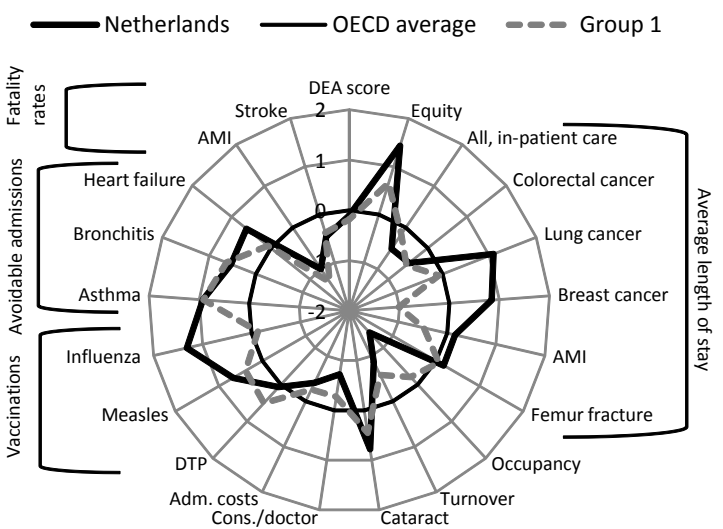

C. Prices and physical resources

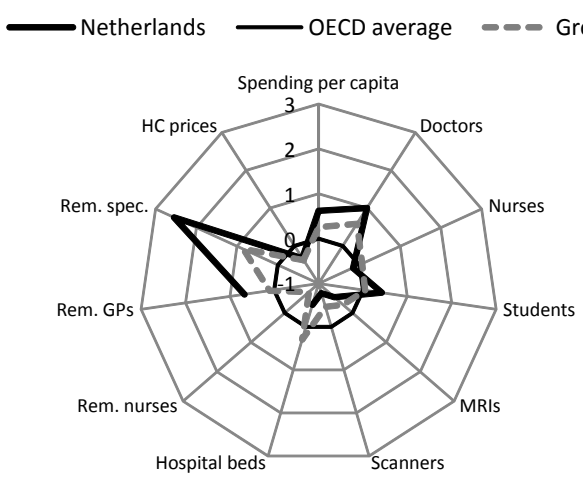

E. Financing and spending $\operatorname{mix}^{1}$

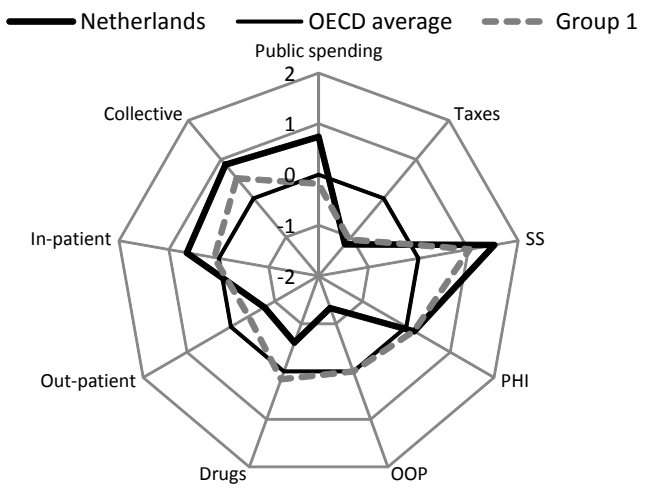

B. Amenable mortality by group of causes

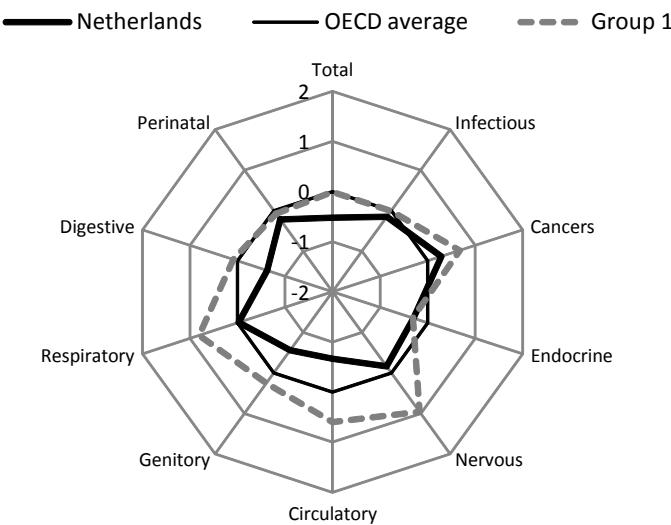

D. Activity and consumption

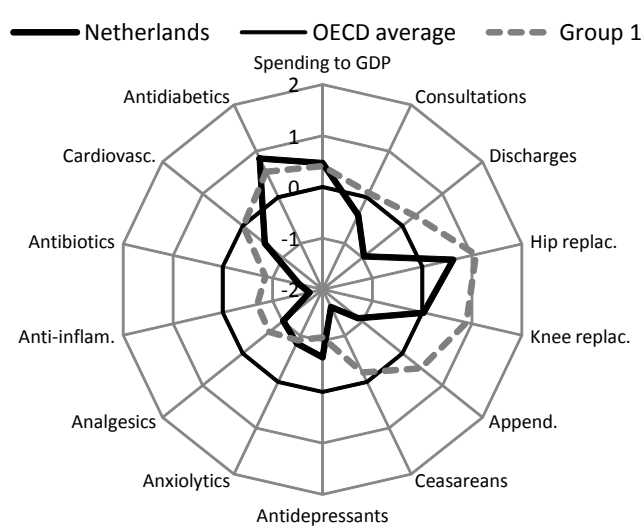

F. Policy and institutions

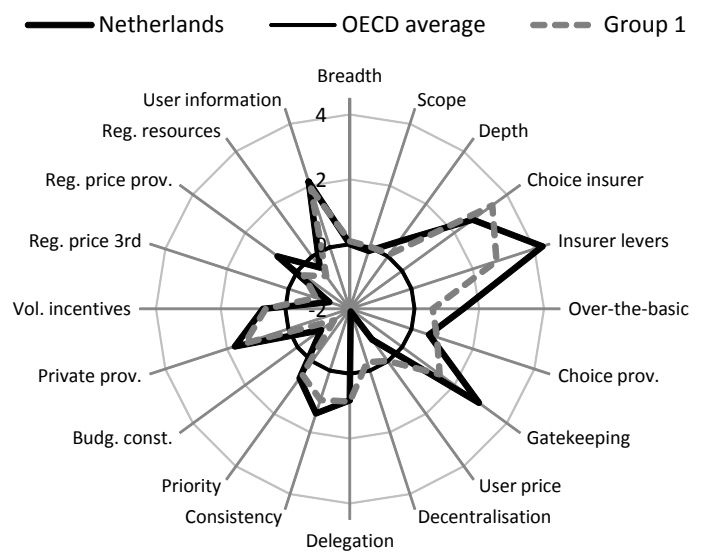

Note: Country groups have been determined by a cluster analysis performed on policy and institutional indicators. In all panels except Panel A, data points outside the average circle indicate that the level of the variable for the group or the country under scrutiny is higher than the average OECD country (e.g. Australia has more scanners than the OECD average country).

In Panel A, data points outside the average circle indicate that the group or the country under scrutiny performs better than the OECD average (e.g. administrative costs as a share of total health care spending are lower in Australia than on average in the OECD area). In all panels except Panel F, data represent the deviation from the OECD average and are expressed in number of standard deviations. In Panel $F$, data shown are simple deviations from the OECD average.

Source: OECD Health Data 2009; OECD Survey on Health Systems Characteristics 2008-2009; Preliminary OECD work based on Nolte and Mc Kee (2008). 
ECO/WKP(2010)25

\section{New Zealand: health care indicators}

Group 6: Hungary, Ireland, Italy, New Zealand, Norway, Poland, United Kingdom

A. Efficiency and quality

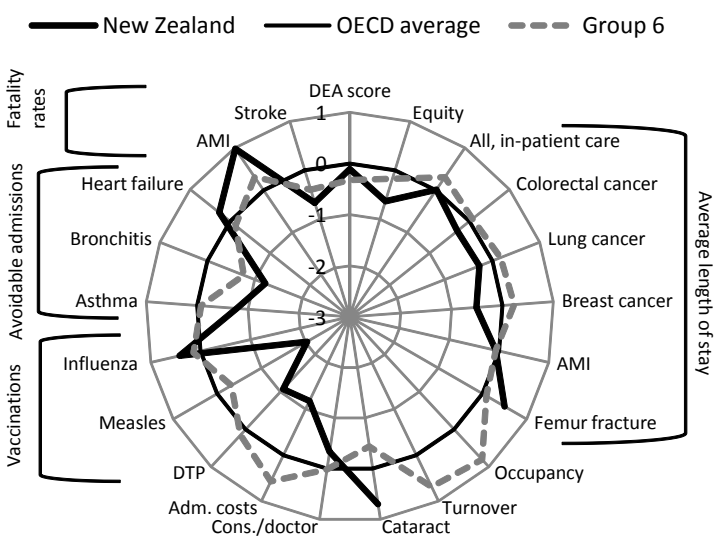

C. Prices and physical resources

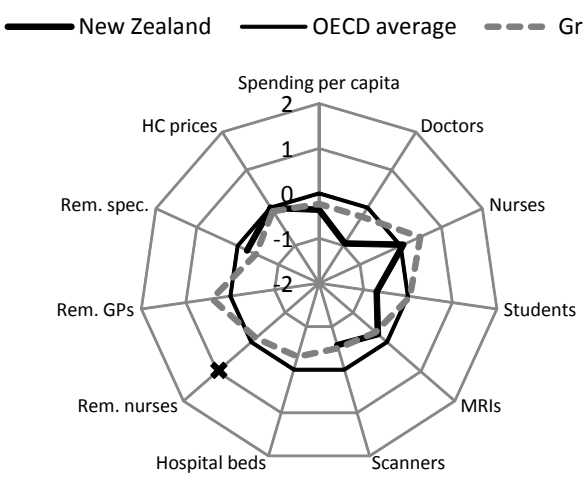

E. Financing and spending mix

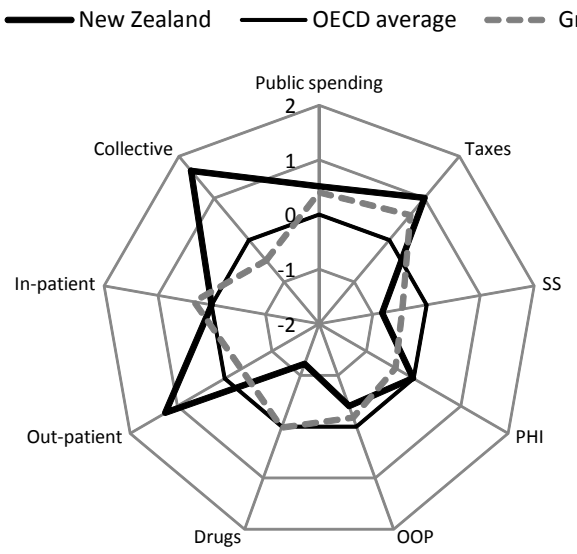

B. Amenable mortality by group of causes

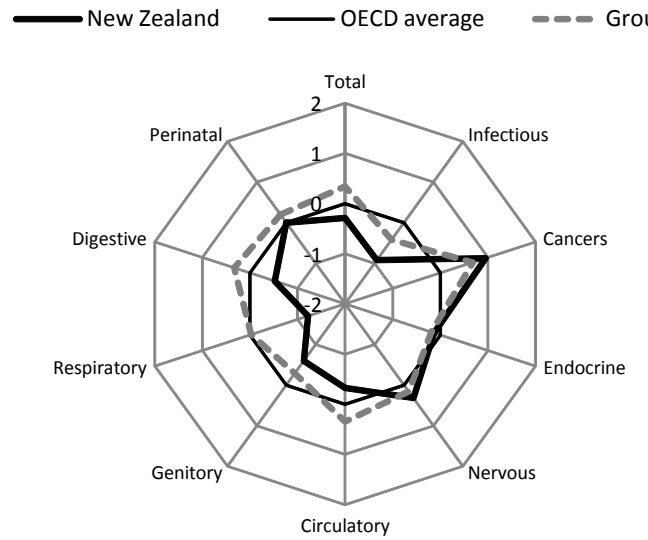

D. Activity and consumption

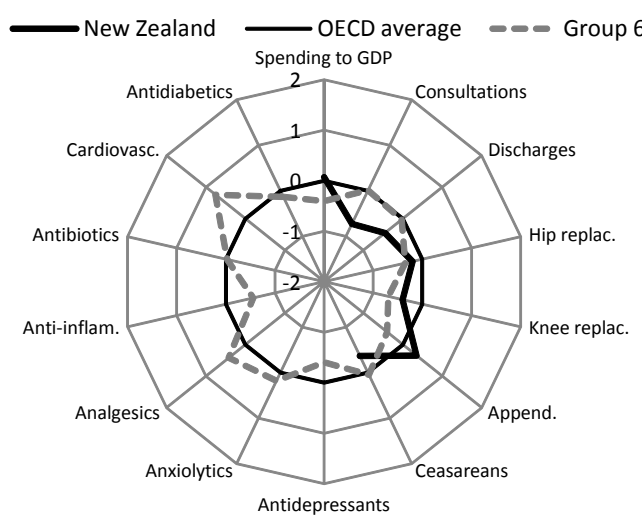

F. Policy and institutions

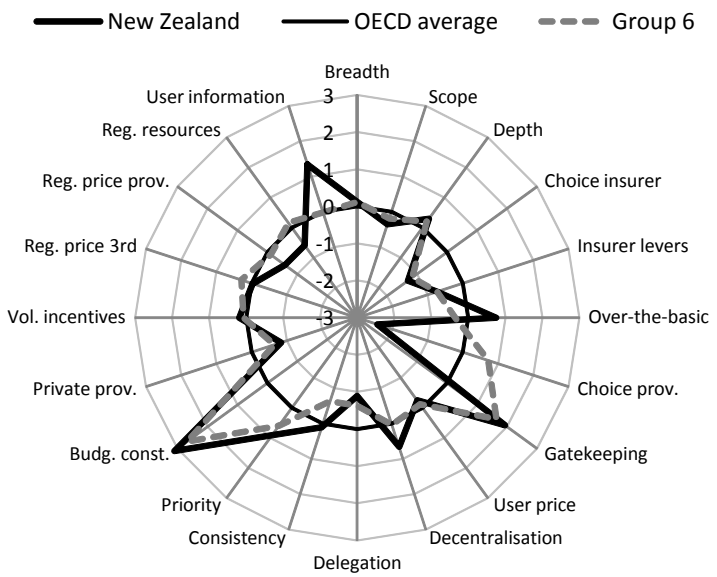

Note: Country groups have been determined by a cluster analysis performed on policy and institutional indicators. In all panels except Panel A, data points outside the average circle indicate that the level of the variable for the group or the country under scrutiny is higher than the average OECD country (e.g. Australia has more scanners than the OECD average country).

In Panel A, data points outside the average circle indicate that the group or the country under scrutiny performs better than the OECD average (e.g. administrative costs as a share of total health care spending are lower in Australia than on average in the OECD area). In all panels except Panel F, data represent the deviation from the OECD average and are expressed in number of standard deviations. In Panel $\mathrm{F}$, data shown are simple deviations from the OECD average.

Source: OECD Health Data 2009; OECD Survey on Health Systems Characteristics 2008-2009; Preliminary OECD work based on Nolte and Mc Kee (2008) 


\section{Norway: health care indicators}

Group 6: Hungary, Ireland, Italy, New Zealand, Norway, Poland, United Kingdom

A. Efficiency and quality

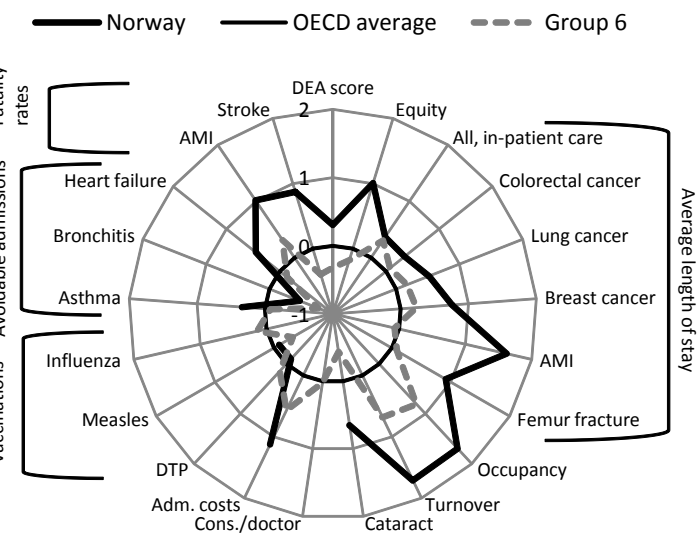

C. Prices and physical resources

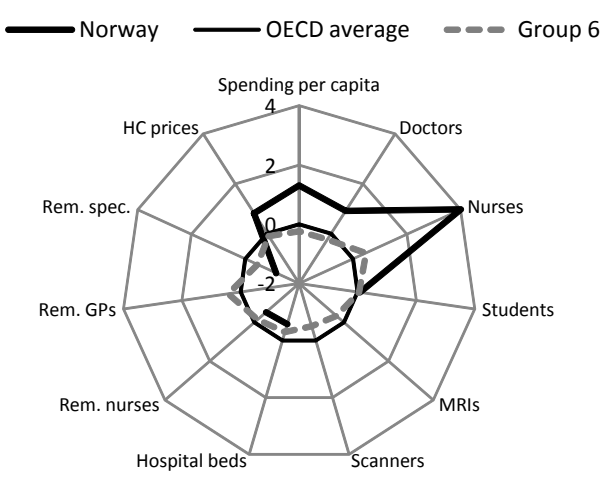

E. Financing and spending mix

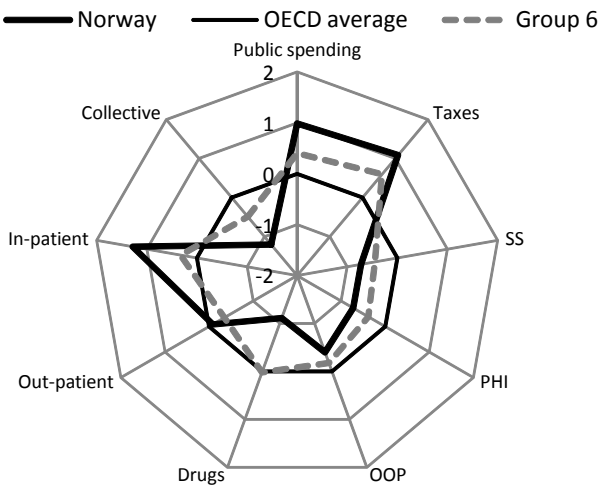

B. Amenable mortality by group of causes

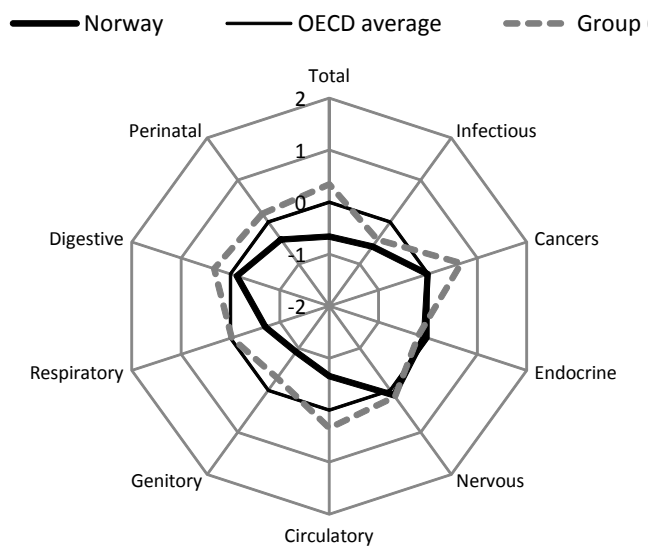

D. Activity and consumption

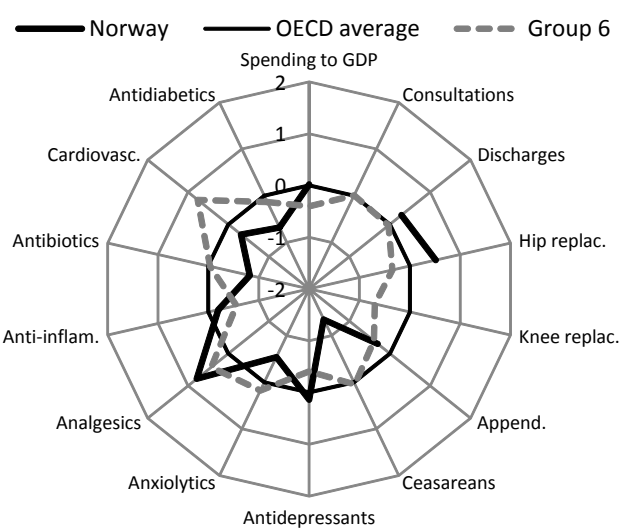

F. Policy and institutions

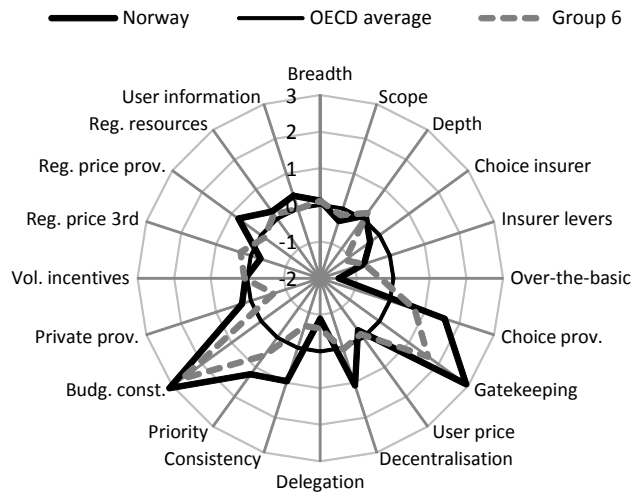

Note: Country groups have been determined by a cluster analysis performed on policy and institutional indicators. In all panels except Panel A, data points outside the average circle indicate that the level of the variable for the group or the country under scrutiny is higher than the average OECD country (e.g. Australia has more scanners than the OECD average country).

In Panel A, data points outside the average circle indicate that the group or the country under scrutiny performs better than the OECD average (e.g. administrative costs as a share of total health care spending are lower in Australia than on average in the OECD area). In all panels except Panel F, data represent the deviation from the OECD average and are expressed in number of standard deviations. In Panel $\mathrm{F}$, data shown are simple deviations from the OECD average.

Source: OECD Health Data 2009; OECD Survey on Health Systems Characteristics 2008-2009; Preliminary OECD work based on Nolte and Mc Kee (2008). 
$\mathrm{ECO} / \mathrm{WKP}(2010) 25$

Poland: health care indicators

Group 6: Hungary, Ireland, Italy, New Zealand, Norway, Poland, United Kingdom

A. Efficiency and quality

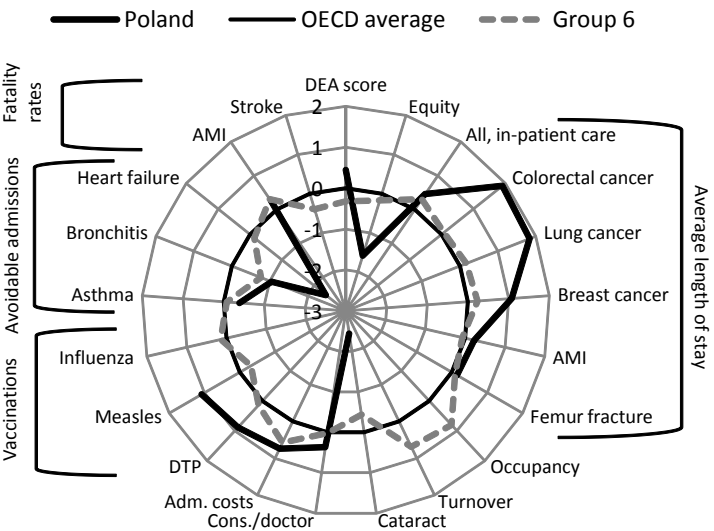

C. Prices and physical resources

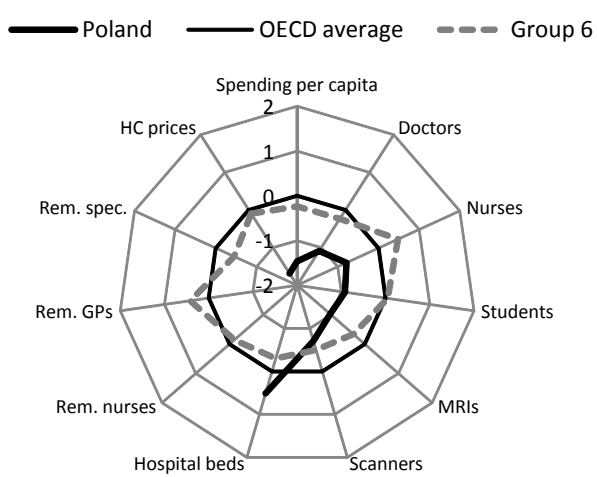

E. Financing and spending mix

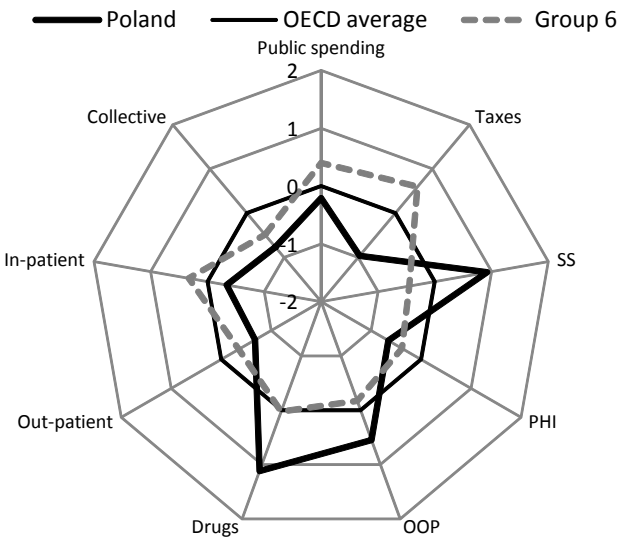

B. Amenable mortality by group of causes

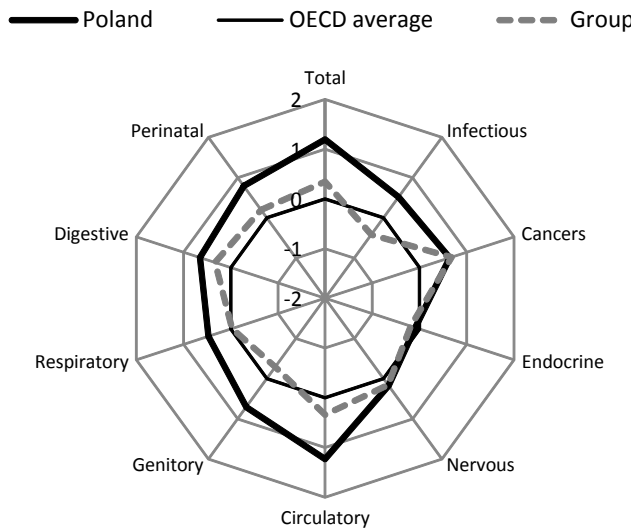

D. Activity and consumption

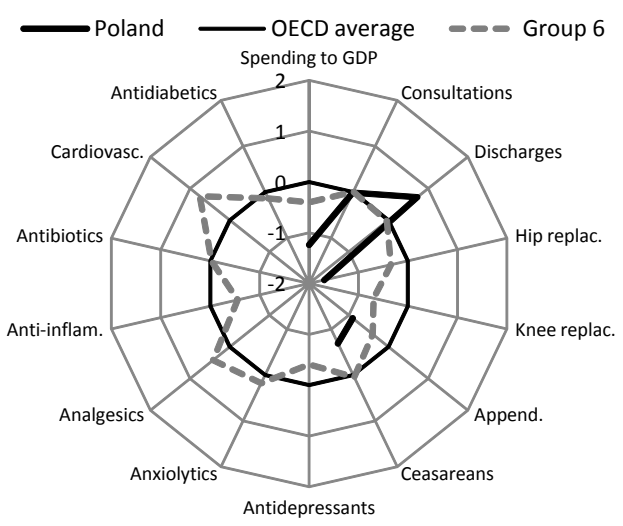

F. Policy and institutions

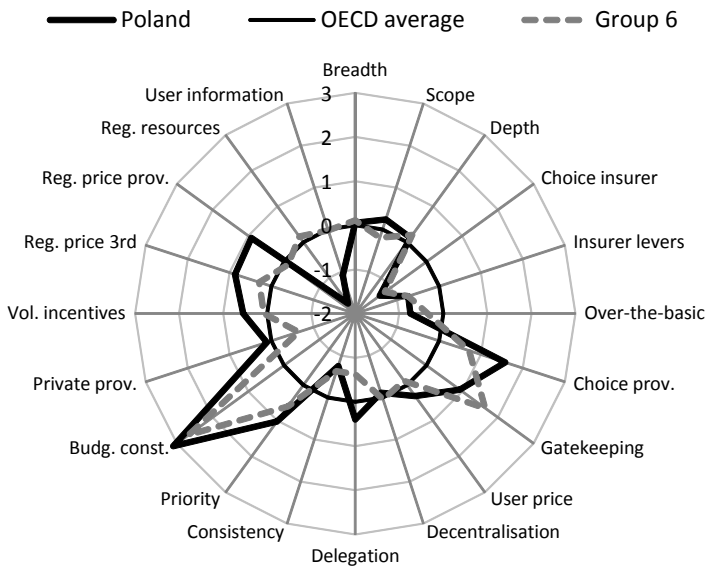

Note: Country groups have been determined by a cluster analysis performed on policy and institutional indicators. In all panels except Panel A, data points outside the average circle indicate that the level of the variable for the group or the country under scrutiny is higher than the average OECD country (e.g. Australia has more scanners than the OECD average country).

In Panel A, data points outside the average circle indicate that the group or the country under scrutiny performs better than the OECD average (e.g. administrative costs as a share of total health care spending are lower in Australia than on average in the OECD area). In all panels except Panel F, data represent the deviation from the OECD average and are expressed in number of standard deviations. In Panel $\mathrm{F}$, data shown are simple deviations from the OECD average.

Source: OECD Health Data 2009; OECD Survey on Health Systems Characteristics 2008-2009; Preliminary OECD work based on Nolte and Mc Kee (2008) 


\section{Portugal: health care indicators}

Group 5: Denmark, Finland, Mexico, Portugal, Spain

A. Efficiency and quality

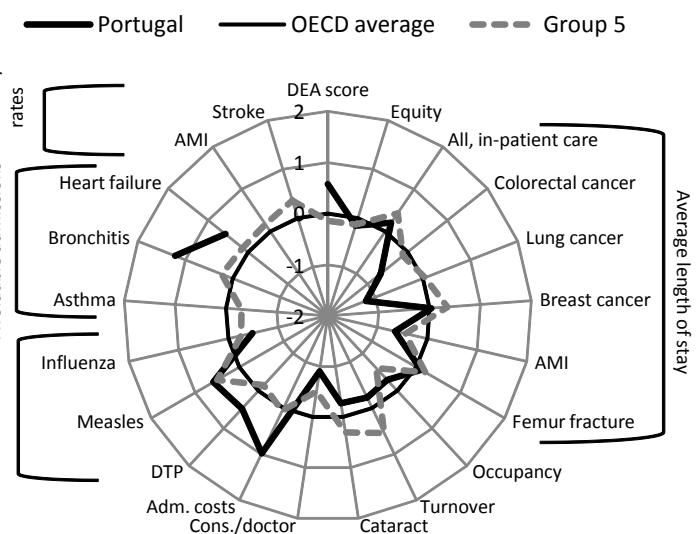

C. Prices and physical resources

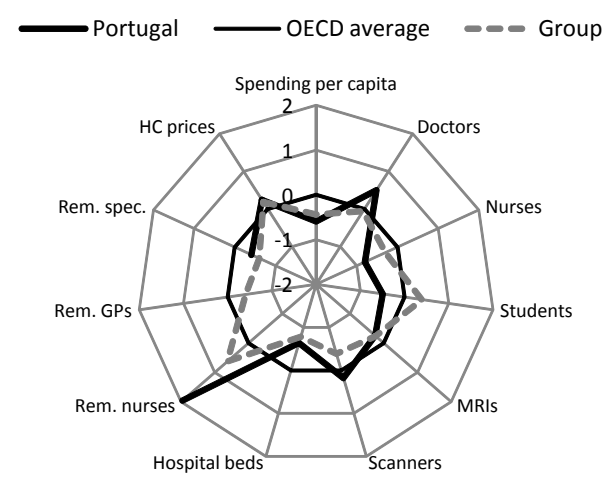

E. Financing and spending mix

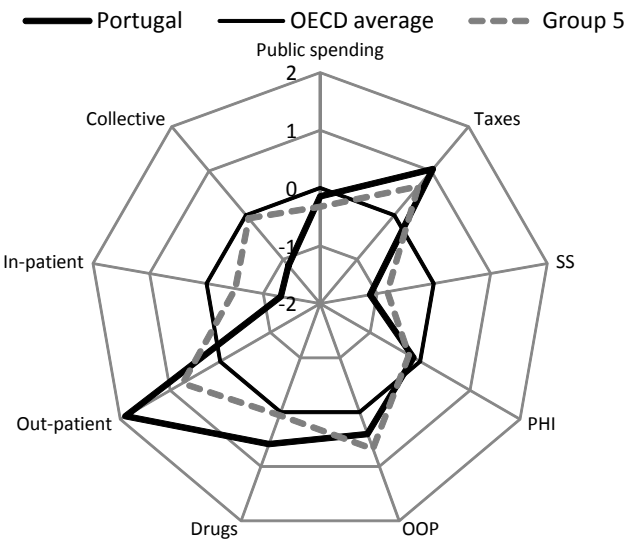

B. Amenable mortality by group of causes

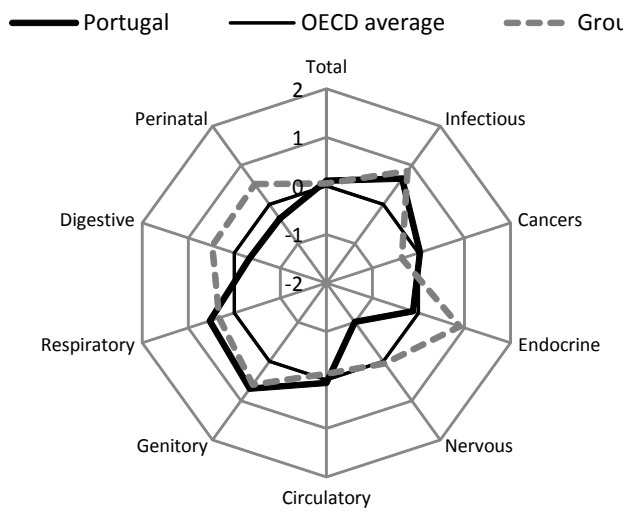

D. Activity and consumption

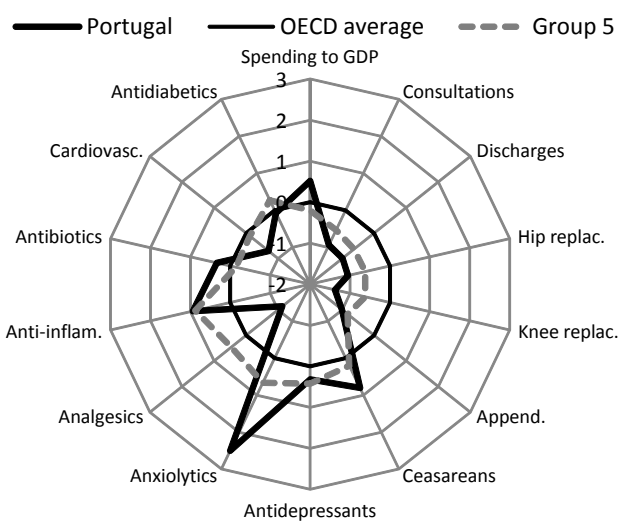

F. Policy and institutions

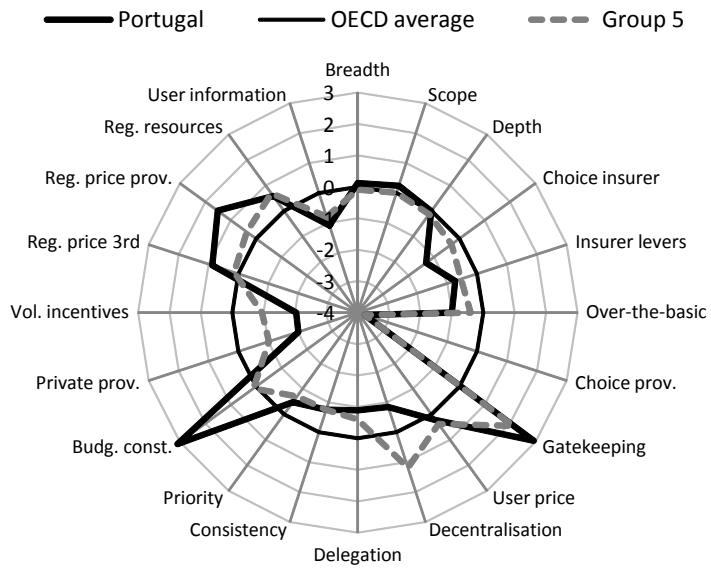

Note: Country groups have been determined by a cluster analysis performed on policy and institutional indicators. In all panels except Panel A, data points outside the average circle indicate that the level of the variable for the group or the country under scrutiny is higher than the average OECD country (e.g. Australia has more scanners than the OECD average country).

In Panel A, data points outside the average circle indicate that the group or the country under scrutiny performs better than the OECD average (e.g. administrative costs as a share of total health care spending are lower in Australia than on average in the OECD area). In all panels except Panel F, data represent the deviation from the OECD average and are expressed in number of standard deviations. In Panel $\mathrm{F}$, data shown are simple deviations from the OECD average.

Source: OECD Health Data 2009; OECD Survey on Health Systems Characteristics 2008-2009; Preliminary OECD work based on Nolte and Mc Kee (2008) 
ECO/WKP(2010)25

\section{Slovak Republic: health care indicators}

Group 1: Germany, Netherlands, Slovak Republic, Switzerland

A. Efficiency and quality

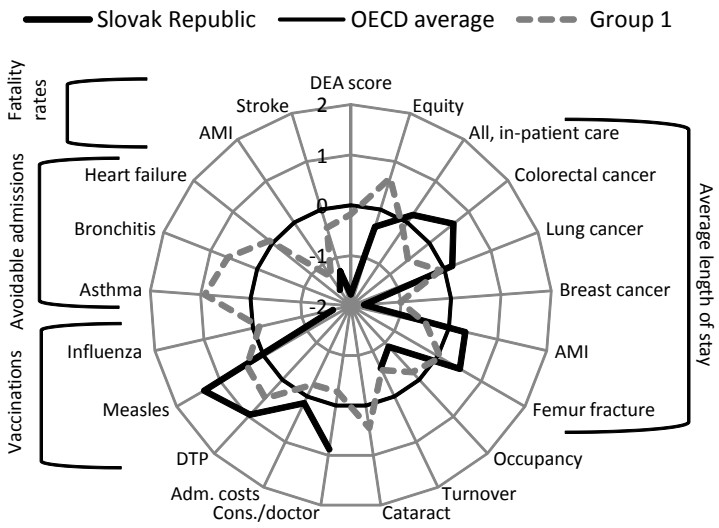

C. Prices and physical resources

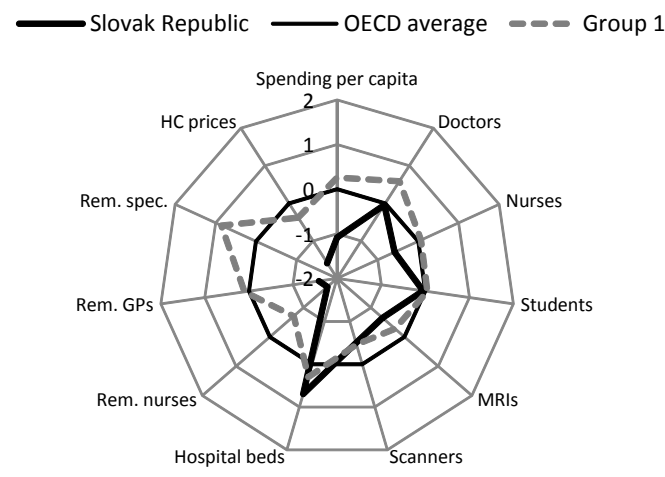

E. Financing and spending mix

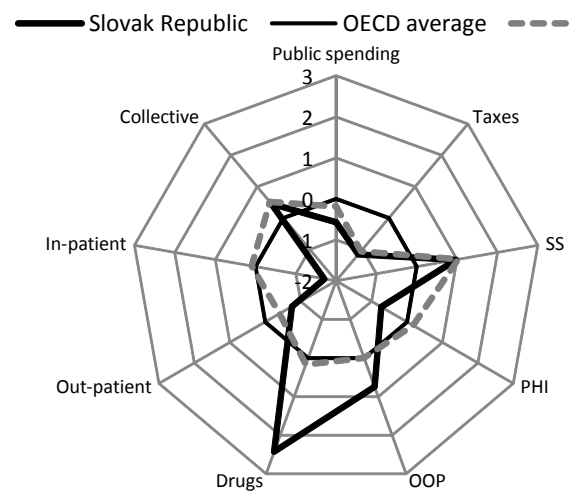

B. Amenable mortality by group of causes

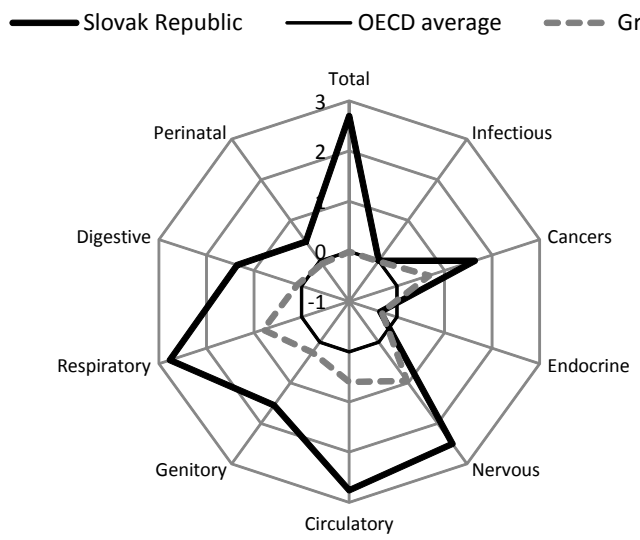

D. Activity and consumption

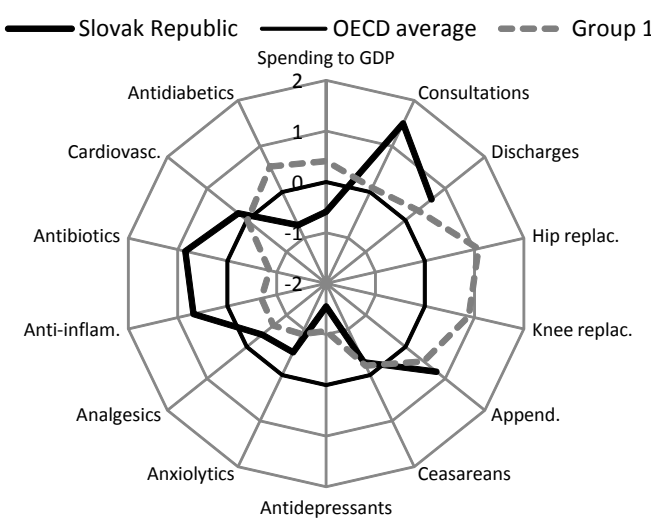

F. Policy and institutions

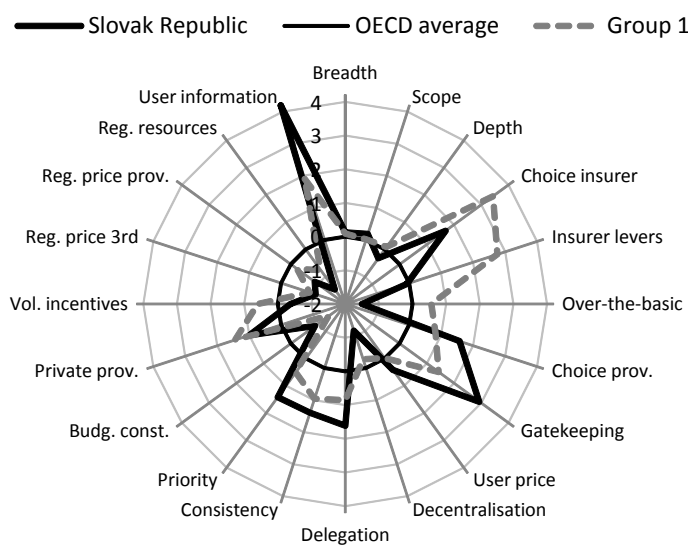

Note: Country groups have been determined by a cluster analysis performed on policy and institutional indicators. In all panels except Panel A, data points outside the average circle indicate that the level of the variable for the group or the country under scrutiny is higher than the average OECD country (e.g. Australia has more scanners than the OECD average country).

In Panel A, data points outside the average circle indicate that the group or the country under scrutiny performs better than the OECD average (e.g. administrative costs as a share of total health care spending are lower in Australia than on average in the OECD area). In all panels except Panel F, data represent the deviation from the OECD average and are expressed in number of standard deviations. In Panel $\mathrm{F}$, data shown are simple deviations from the OECD average.

Source: OECD Health Data 2009; OECD Survey on Health Systems Characteristics 2008-2009; Preliminary OECD work based on Nolte and Mc Kee (2008) 
Spain: health care indicators

Group 5: Denmark, Finland, Mexico, Portugal, Spain

A. Efficiency and quality

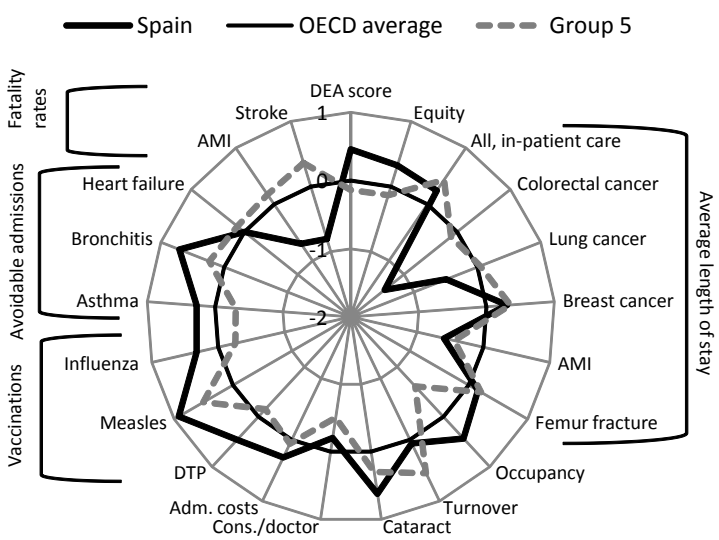

C. Prices and physical resources

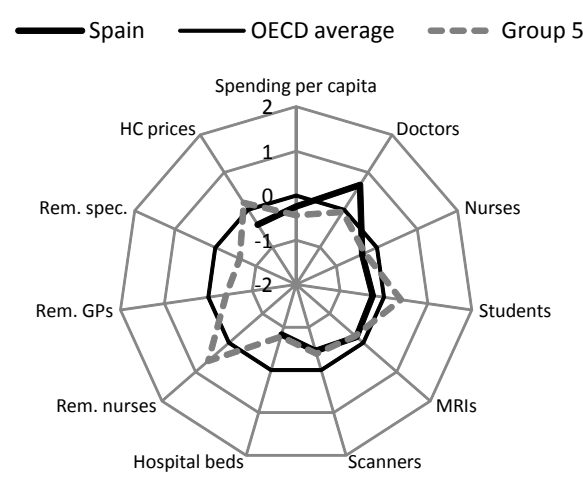

E. Financing and spending mix

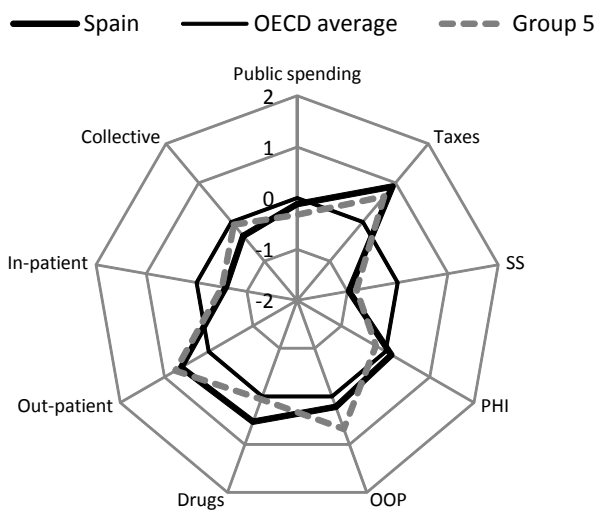

B. Amenable mortality by group of causes

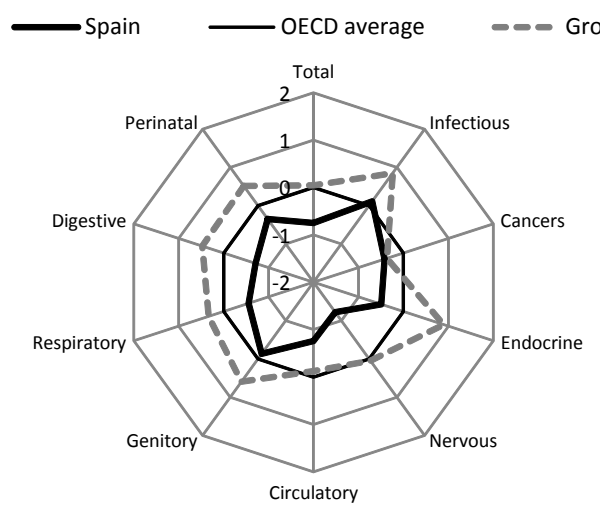

D. Activity and consumption

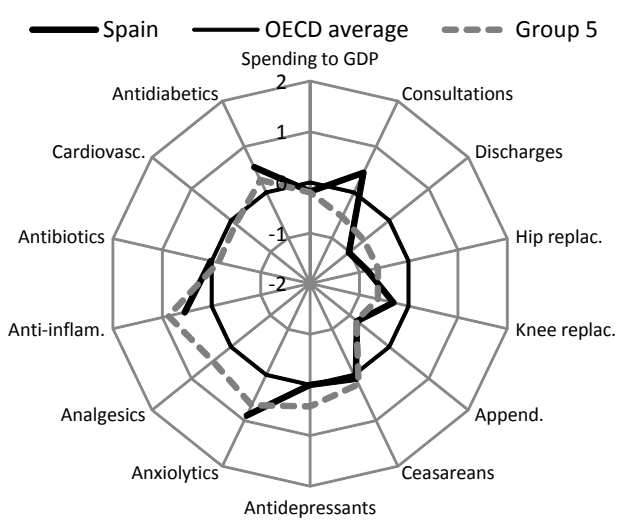

F. Policy and institutions

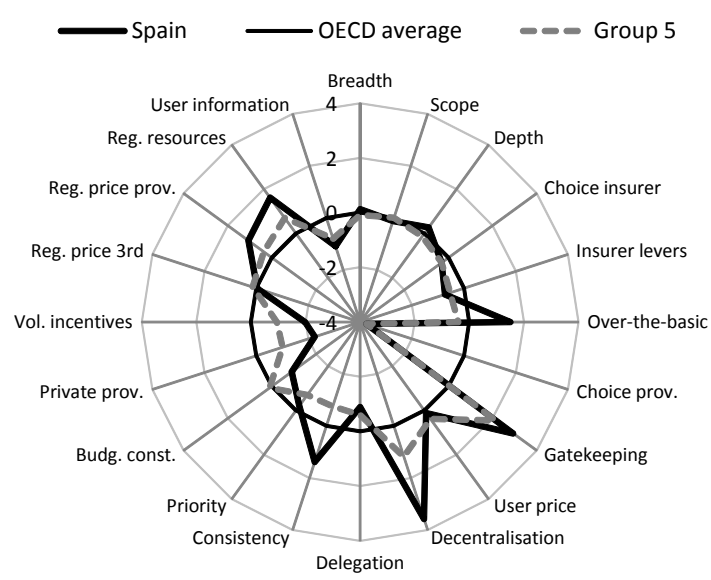

Note: Country groups have been determined by a cluster analysis performed on policy and institutional indicators. In all panels except Panel A, data points outside the average circle indicate that the level of the variable for the group or the country under scrutiny is higher than the average OECD country (e.g. Australia has more scanners than the OECD average country).

In Panel A, data points outside the average circle indicate that the group or the country under scrutiny performs better than the OECD average (e.g. administrative costs as a share of total health care spending are lower in Australia than on average in the OECD area). In all panels except Panel F, data represent the deviation from the OECD average and are expressed in number of standard deviations. In Panel $\mathrm{F}$, data shown are simple deviations from the OECD average.

Source: OECD Health Data 2009; OECD Survey on Health Systems Characteristics 2008-2009; Preliminary OECD work based on Nolte and Mc Kee (2008). 
ECO/WKP(2010)25

\section{Sweden: health care indicators}

Group 4: Iceland, Sweden, Turkey

A. Efficiency and quality

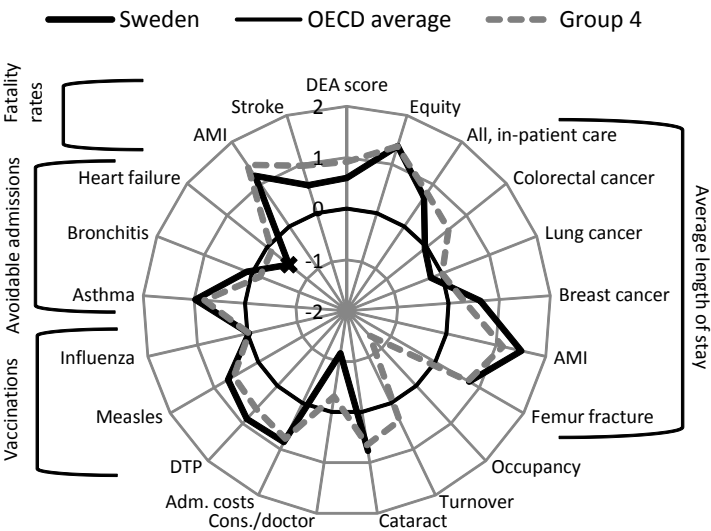

C. Prices and physical resources

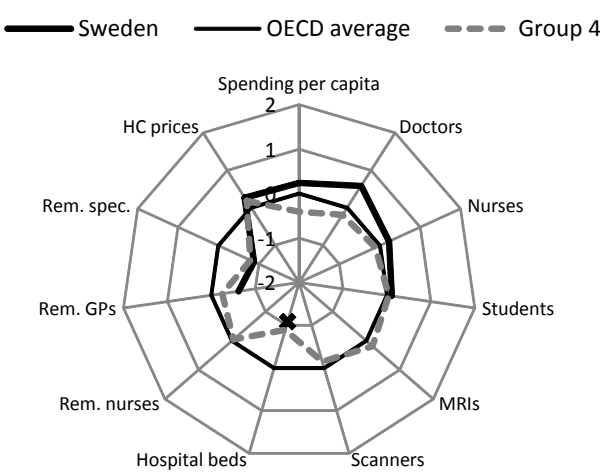

E. Financing and spending mix

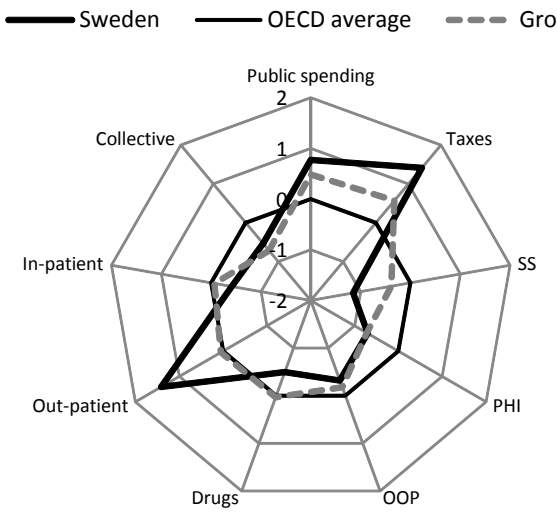

B. Amenable mortality by group of causes

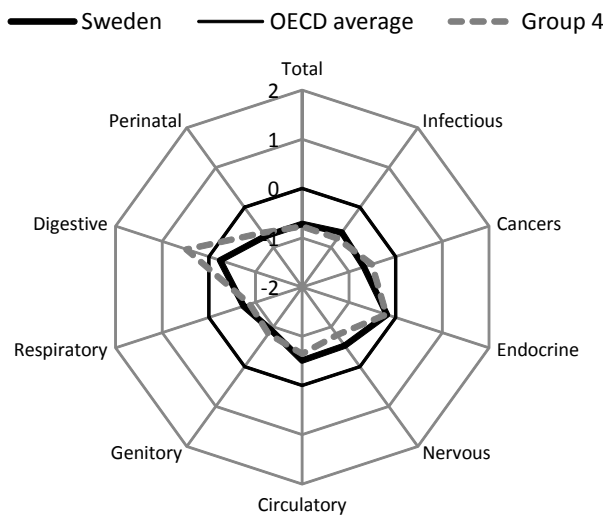

D. Activity and consumption

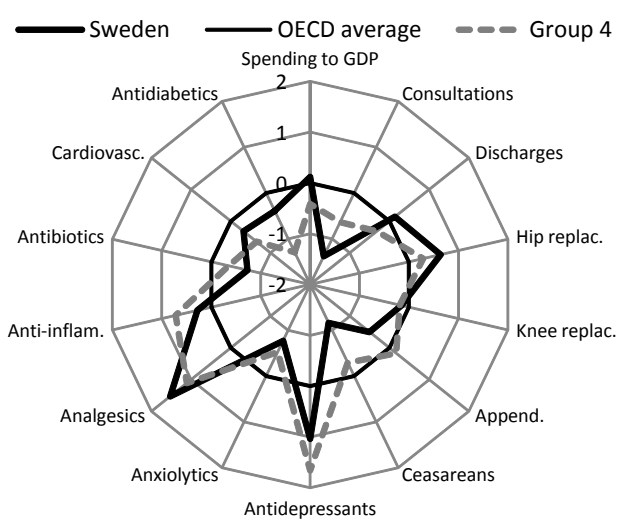

F. Policy and institutions

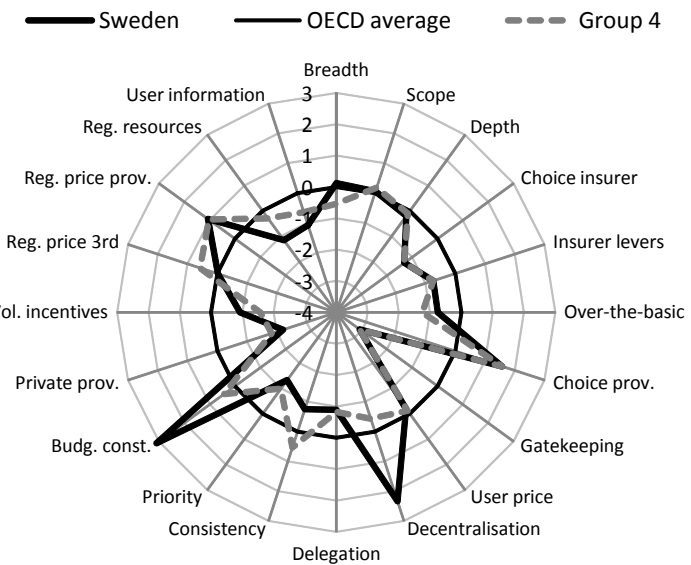

Note: Country groups have been determined by a cluster analysis performed on policy and institutional indicators. In all panels except Panel A, data points outside the average circle indicate that the level of the variable for the group or the country under scrutiny is higher than the average OECD country (e.g. Australia has more scanners than the OECD average country).

In Panel A, data points outside the average circle indicate that the group or the country under scrutiny performs better than the OECD average (e.g. administrative costs as a share of total health care spending are lower in Australia than on average in the OECD area). In all panels except Panel F, data represent the deviation from the OECD average and are expressed in number of standard deviations. In Panel $F$, data shown are simple deviations from the OECD average.

Source: OECD Health Data 2009; OECD Survey on Health Systems Characteristics 2008-2009; Preliminary OECD work based on Nolte and Mc Kee (2008) 


\section{Switzerland: health care indicators}

Group 1: Germany, Netherlands, Slovak Republic, Switzerland

A. Efficiency and quality

B. Amenable mortality by group of causes

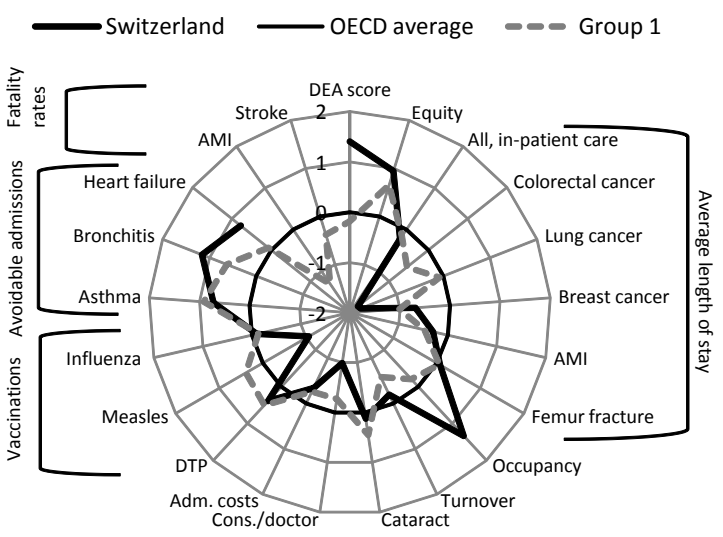

Data not available

C. Prices and physical resources

D. Activity and consumption
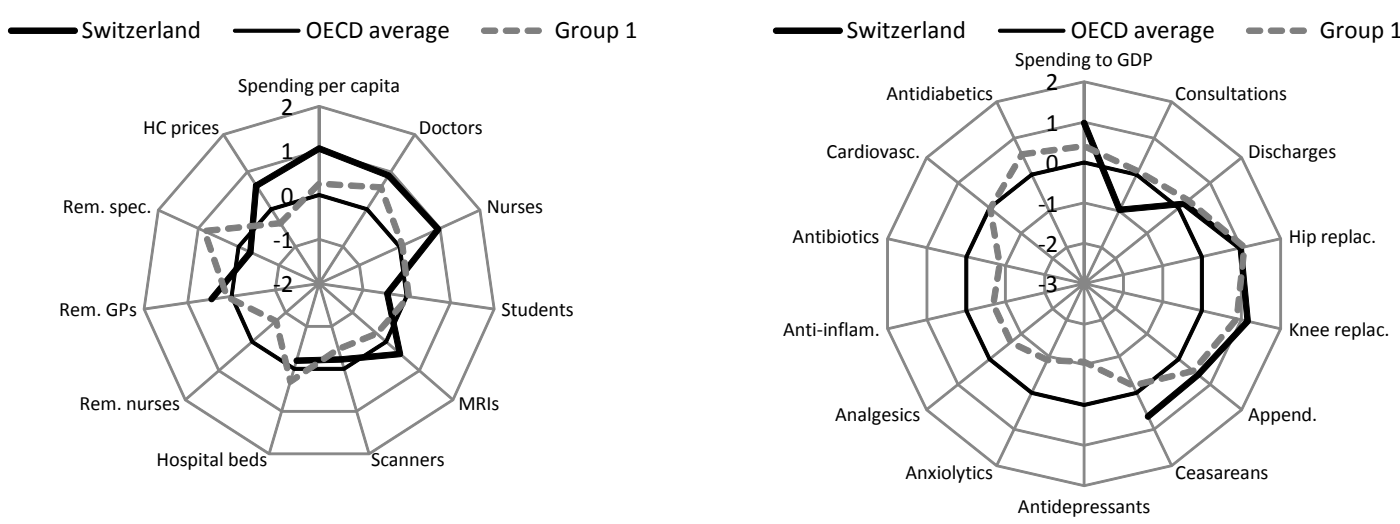

E. Financing and spending mix

F. Policy and institutions
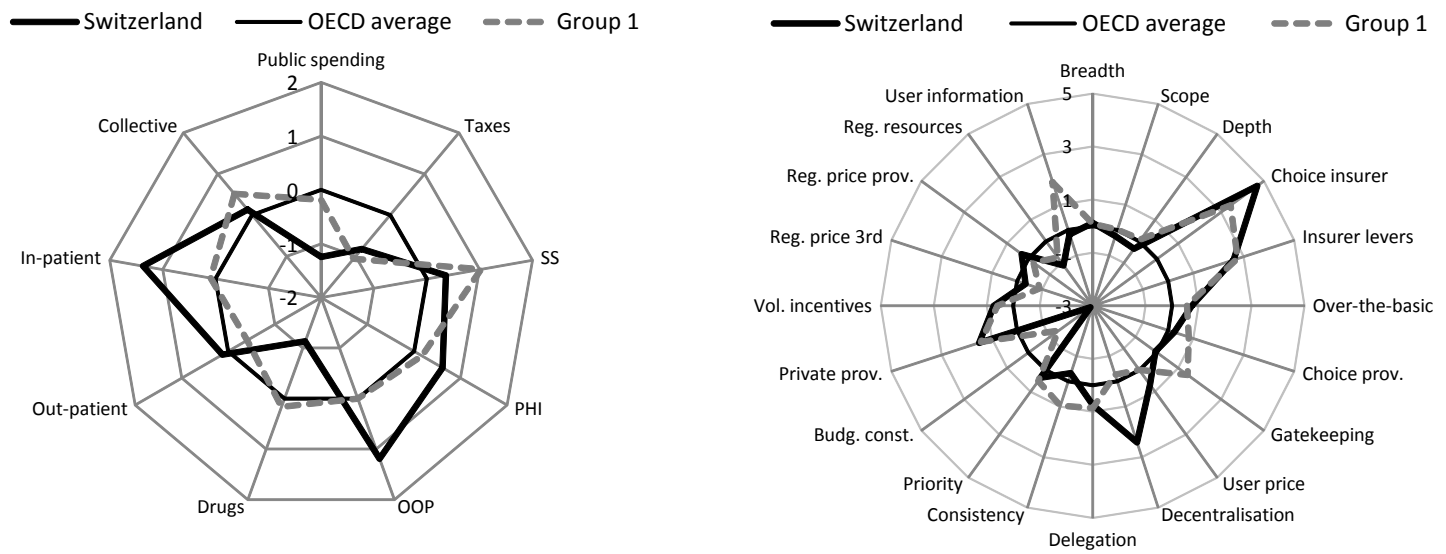

Note: Country groups have been determined by a cluster analysis performed on policy and institutional indicators. In all panels except Panel A, data points outside the average circle indicate that the level of the variable for the group or the country under scrutiny is higher than the average OECD country (e.g. Australia has more scanners than the OECD average country).

In Panel A, data points outside the average circle indicate that the group or the country under scrutiny performs better than the OECD average (e.g. administrative costs as a share of total health care spending are lower in Australia than on average in the OECD area). In all panels except Panel F, data represent the deviation from the OECD average and are expressed in number of standard deviations. In Panel $\mathrm{F}$, data shown are simple deviations from the OECD average.

Source: OECD Health Data 2009; OECD Survey on Health Systems Characteristics 2008-2009; Preliminary OECD work based on Nolte and Mc Kee (2008). 
ECO/WKP(2010)25

Turkey: health care indicators

Group 4: Iceland, Sweden, Turkey

A. Efficiency and quality

B. Amenable mortality by group of causes

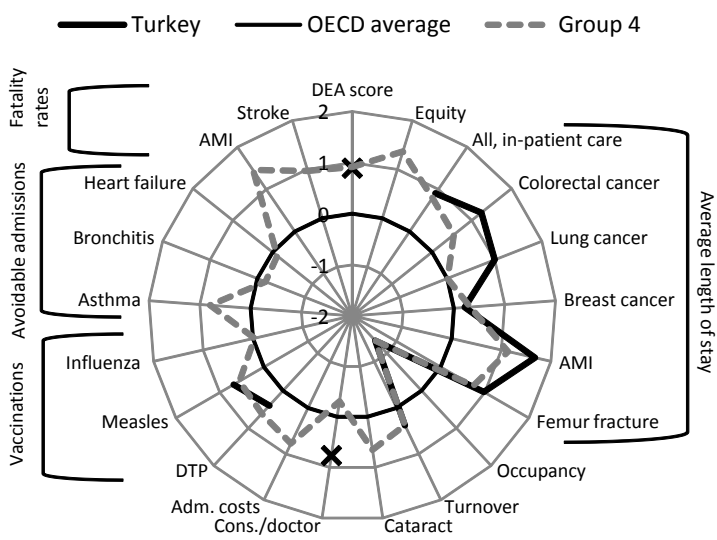

Data not available

C. Prices and physical resources

D. Activity and consumption

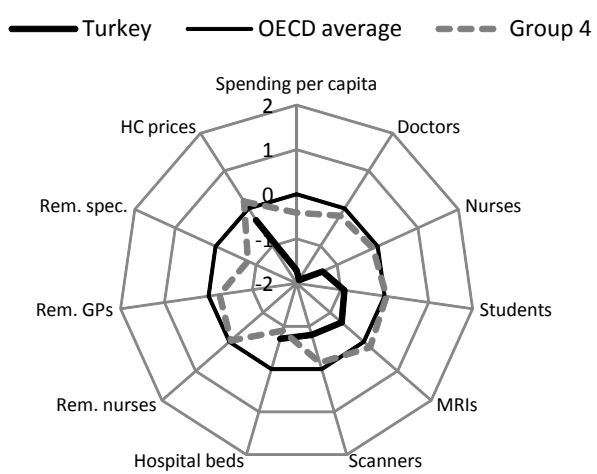

E. Financing and spending mix ${ }^{1}$

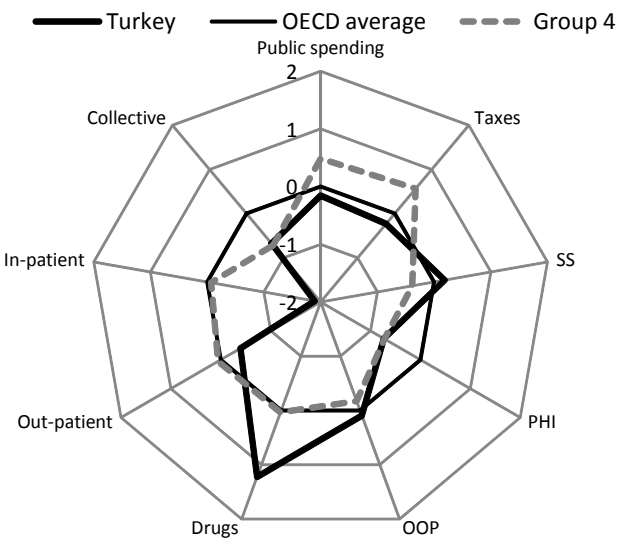

F. Policv and institutions

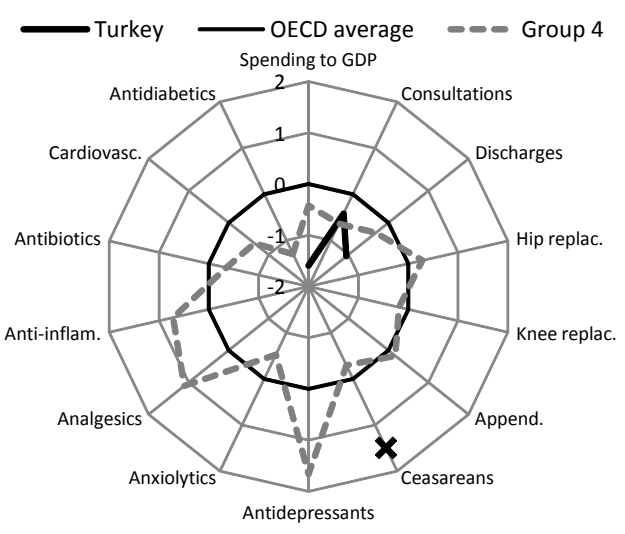

- OECD average - - Group 4

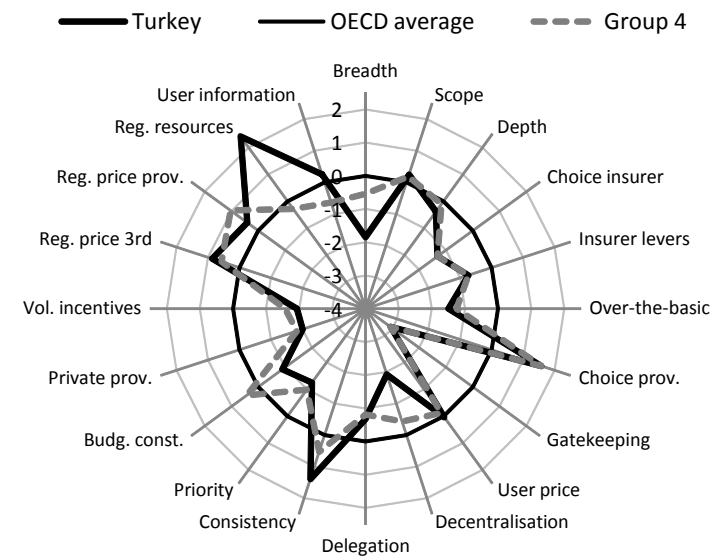

Note: Country groups have been determined by a cluster analysis performed on policy and institutional indicators. In all panels except Panel A, data points outside the average circle indicate that the level of the variable for the group or the country under scrutiny is higher than the average OECD country (e.g. Australia has more scanners than the OECD average country).

In Panel A, data points outside the average circle indicate that the group or the country under scrutiny performs better than the OECD average (e.g. administrative costs as a share of total health care spending are lower in Australia than on average in the OECD area). In all panels except Panel F, data represent the deviation from the OECD average and are expressed in number of standard deviations In Panel $F$, data shown are simple deviations from the OECD average.

Source: OECD Health Data 2009; OECD Survey on Health Systems Characteristics 2008-2009; Preliminary OECD work based on Nolte and Mc Kee (2008) 
United Kingdom: health care indicators

Group 6: Hungary, Ireland, Italy, New Zealand, Norway, Poland, United Kingdom

A. Efficiency and quality

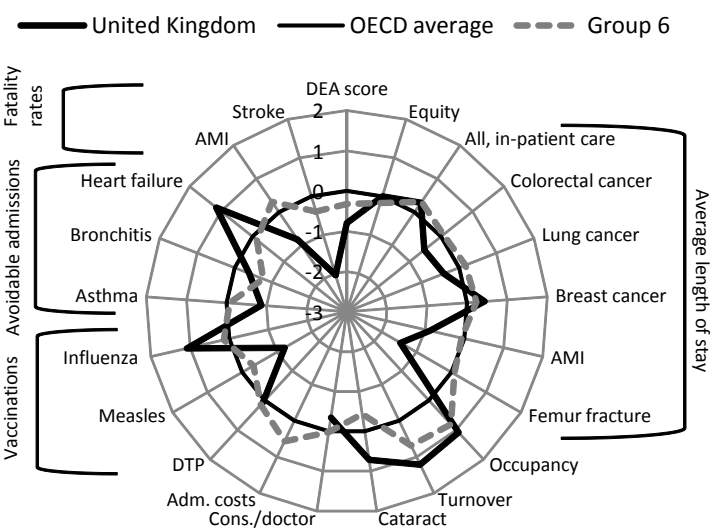

C. Prices and physical resources

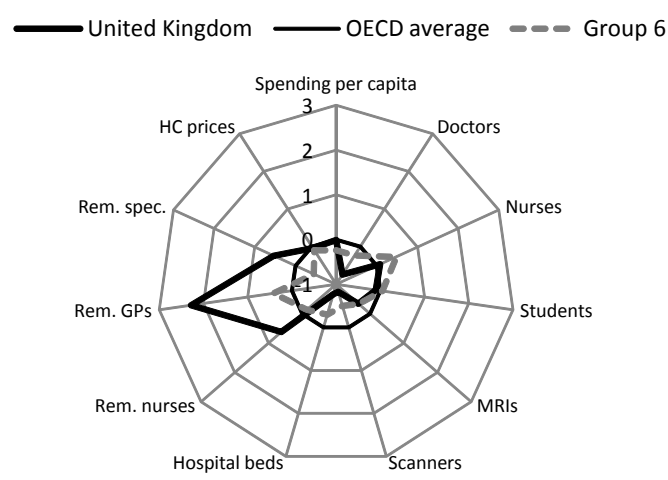

E. Financing and spending mix

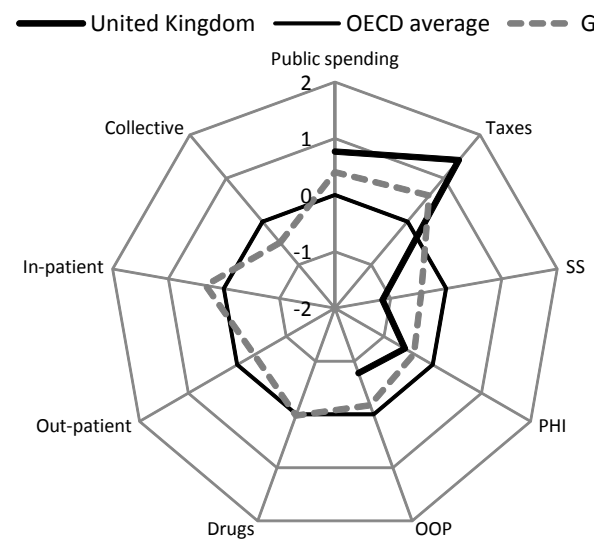

B. Amenable mortality by group of causes

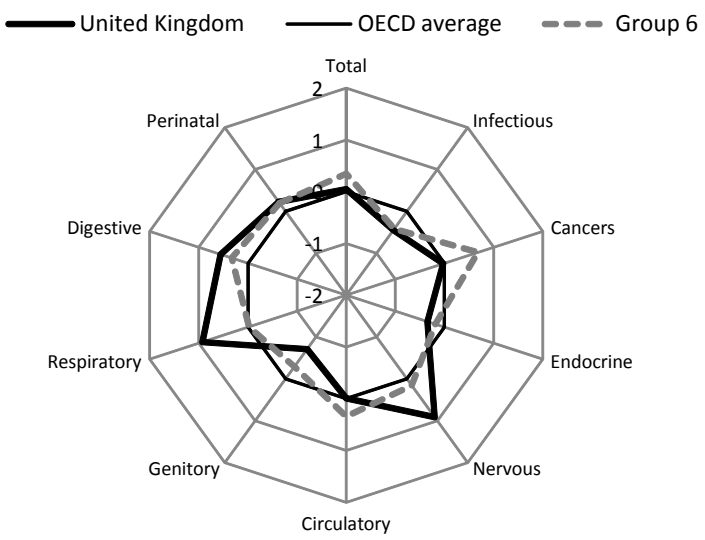

D. Activity and consumption

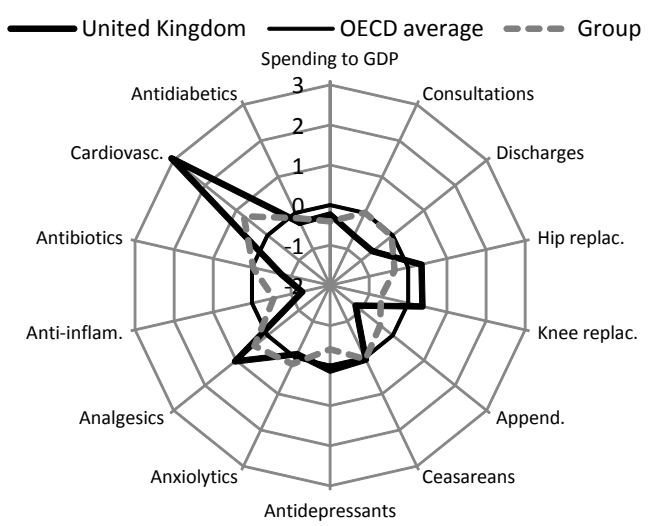

F. Policy and institutions

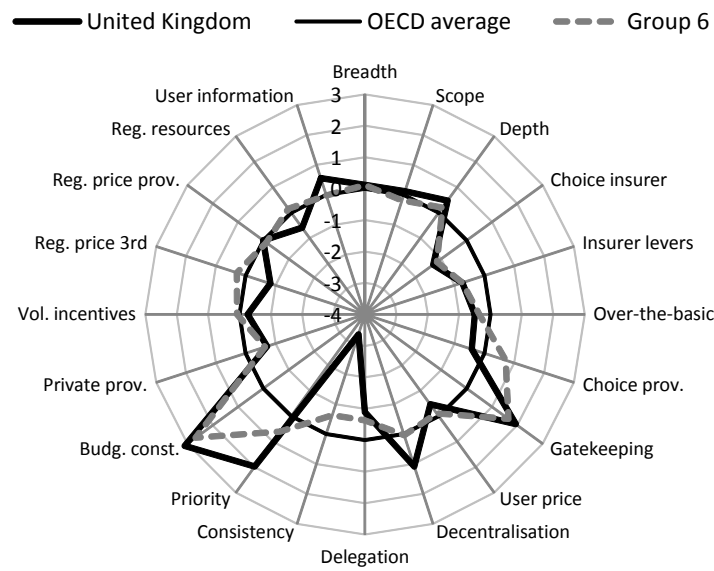

Note: Country groups have been determined by a cluster analysis performed on policy and institutional indicators. In all panels except Panel A, data points outside the average circle indicate that the level of the variable for the group or the country under scrutiny is higher than the average OECD country (e.g. Australia has more scanners than the OECD average country).

In Panel A, data points outside the average circle indicate that the group or the country under scrutiny performs better than the OECD average (e.g. administrative costs as a share of total health care spending are lower in Australia than on average in the OECD area). In all panels except Panel F, data represent the deviation from the OECD average and are expressed in number of standard deviations. In Panel $F$, data shown are simple deviations from the OECD average.

Source: OECD Health Data 2009; OECD Survey on Health Systems Characteristics 2008-2009; Preliminary OECD work based on Nolte and Mc Kee (2008) 
ECO/WKP(2010)25

\section{United States: health care indicators}

A. Efficiency and quality

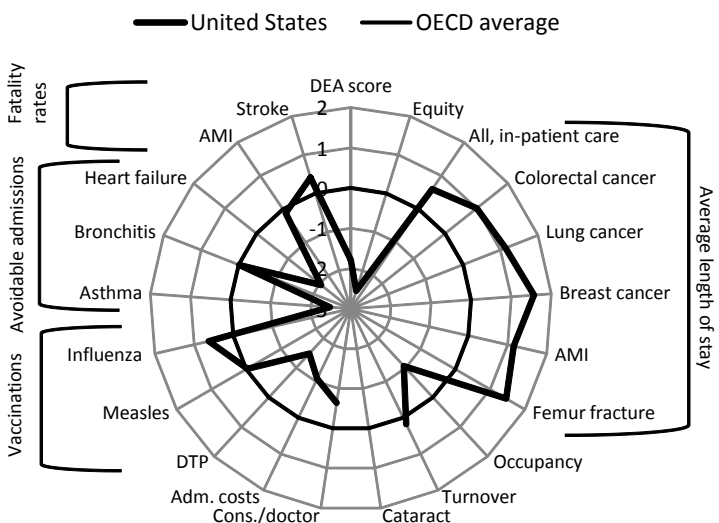

C. Prices and physical resources

- United States _ OECD average

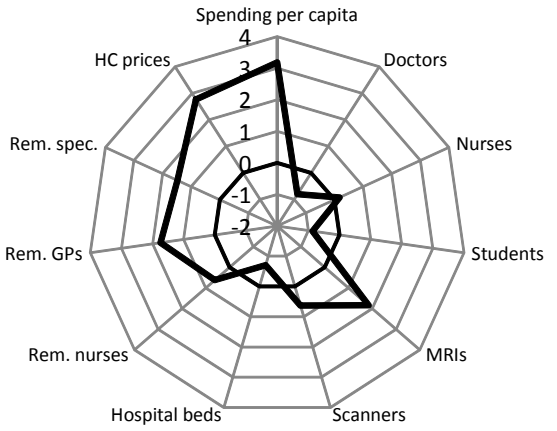

E. Financing and spending mix

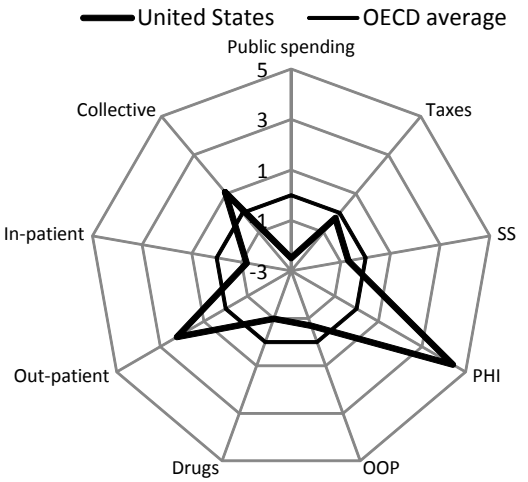

B. Amenable mortality by group of causes

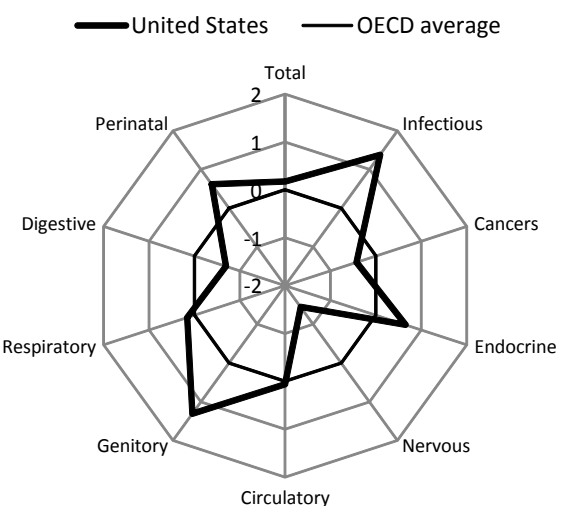

D. Activity and consumption

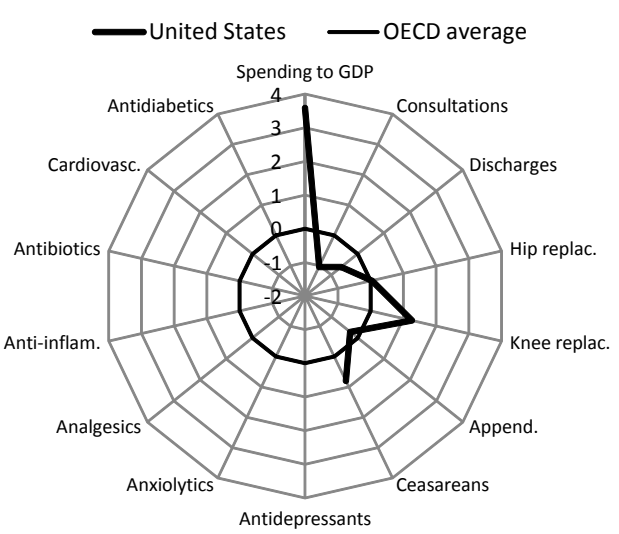

F. Policy and institutions

Data not available

Note: Country groups have been determined by a cluster analysis performed on policy and institutional indicators. In all panels except Panel A, data points outside the average circle indicate that the level of the variable for the group or the country under scrutiny is higher than the average OECD country (e.g. Australia has more scanners than the OECD average country).

In Panel $A$, data points outside the average circle indicate that the group or the country under scrutiny performs better than the OECD average (e.g. administrative costs as a share of total health care spending are lower in Australia than on average in the OECD area). In all panels except Panel F, data represent the deviation from the OECD average and are expressed in number of standard deviations. In Panel $\mathrm{F}$, data shown are simple deviations from the OECD average.

Source: OECD Health Data 2009; OECD Survey on Health Systems Characteristics 2008-2009; Preliminary OECD work based on Nolte and Mc Kee (2008) 


\section{Annex 4.}

\section{Market failures and imperfections in health care systems and government interventions}

Competitive markets have long been considered by mainstream economists as leading to an efficient allocation of resources and maximisation of social welfare in many situations. The neo-classical economic theory demonstrates that the equilibrium attained in a perfectly competitive market is optimal in the Pareto sense, i.e. no other allocation of resources can make all market participants better off. ${ }^{1}$ However, such a competitive equilibrium can only be achieved under certain conditions, many of which are violated in the health care sector. Since the pioneering work by Arrow (1963), a large body of literature has investigated the reasons for market failures in both health care services and insurance. This Annex provides an overview of these market failures and reviews government interventions designed to address them.

\section{Market failures and imperfections in health care services}

\section{Externalities}

The consumption of health care services can provide benefits not only for an individual but also to others. An obvious example is the treatment for communicable diseases and immunisation. In the presence of such externalities, consumption determined by the market is socially sub-optimal, calling for public intervention. In addition, some health-care related activities, in particular in research and development, have public goods characteristics (Smith, 2008).

\section{Informational asymmetries}

The assumption of consumer sovereignty is generally violated in health care markets, ${ }^{2}$ as providers often have a dominant market position over patients and payers (either insurers or government) because they have more information on the need for and appropriateness of medical care. Furthermore, there are limited opportunities for individuals to assess the quality of care from experience and individuals often have to make decisions while being vulnerable (Hurley, 2000). As a result, patients mainly rely on medical advice. Hence, demand can be supply-induced, eventually leading to over-consumption. ${ }^{3}$ A number of policies can mitigate informational problems. On the demand side, information on the quality of health care can be made available to patients. On the supply side, providers' autonomy can be limited through utilisation reviews, pre-authorization programmes, practice guidelines and promotion of prevention - as in

1. The Pareto-optimal allocation of resources might not be optimal from a social point of view. A change in allocation of resources which would greatly improve the situation of most market participants, while deteriorating modestly that of a few, would certainly be desirable from a social standpoint. In perfectly competitive markets, money transfers (tax and subsidies) can be used to achieve an equilibrium in line with social preferences (Arrow, 1963).

2. Consumer sovereignty refers to the fact that, in a perfectly competitive market, consumers ultimately dictate what is to be produced.

3. Behavioural economics suggests that a number of additional factors - e.g. limited ability of patients to process information or the desire to avoid regret-might contribute to what appears as demand inducements (Frank, 2004). 
managed care settings. Compensation systems can also be designed to limit incentives to increase the volume of care $-e . g$. paying physicians by capitation or wages rather than fee-for-service.

Informational asymmetries also exist between health regulators and providers. Medical expertise is required to assess the effectiveness of medical practice. Hence, governments have granted health professionals large powers of self-regulation, thereby strengthening their position. Similarly, health care providers have an informational advantage over insurers, limiting the ability of the latter to assess the value of health care.

\section{Barriers to entry and exit}

Competitive markets assume free entry and exit. In the health care sector, entry of providers is highly regulated to ensure the quality of care. ${ }^{4}$ In many cases, health care providers do not face a credible threat of closure. It is, for instance, politically difficult to close local hospitals (Smith, 2008).

\section{Monopoly power}

In many cases, health care providers enjoy some monopoly power, stemming either from technical characteristics of health care - e.g. economies of scale - or from government intervention aimed at guaranteeing the quality of care or by granting intellectual property rights. Economies of scale in the hospital sector imply that "in many specialties and geographic locations there exists little realistic choice of provider" (Smith, 2008). Patent laws grant a monopoly to new drugs and medical technologies (Hsiao and Heller, 2007).

\section{Market failures and imperfections in the insurance sector}

Uncertainty is a central feature of health care: individuals are facing uncertainties about the occurrence of a disease and the effectiveness of treatment. The ability to reach a competitive equilibrium in health insurance markets depends on the existence of a full set of markets covering these risks, but this proves impossible in practice because of a number of market failures, such as adverse selection and moral hazard. $^{5}$

\section{Risk selection}

The asymmetry of information between the consumer and the insurer about the former's health condition results in adverse selection - those with greater risks are more likely to subscribe to health insurance at a higher level than those in good health. Premiums set according to average risk will thus not be sufficient to cover claims. And rising premiums will lead low-risk individuals to cancel their insurance policies. Compulsory insurance is an obvious answer to adverse selection.

Cream-skimming or risk selection by insurers designates the ability of insurers to select low-risk individuals and avoid covering high-risk ones. Cream-skimming can be addressed through regulation limiting risk selection practices and/or by creating systems of risk-equalisation which allow redistribution between low- and high-risk insurance pools.

4. There may be technical obstacles to market entry: for instance, training doctors and building hospitals take a considerable amount of time.

5. Arrow (1963) argues that the fact that a full set of insurance markets does not exist explains the development of non-market social institutions. 


\section{Moral hazard}

When patients do not bear the full cost of medical care, they might be inclined to consume more than necessary. Similarly, health providers, knowing that their patients are well insured, might tend to prescribe more care than required, especially if they can derive a financial benefit. Avoiding compensation systems which provide incentives for providers to increase volumes of care and promoting evidence-based medical practice can mitigate moral hazard. Increasing cost-sharing can also reduce moral hazard, but with the risk of putting some individuals at risk financially and raising equity concerns.

\section{Economies of scale}

Fixed administrative costs and efficiency gains associated with risk-pooling generate economies of scale. Hence, having a large number of small firms will lead to technical inefficiencies, while having a small number of large firms will produce monopolistic positions. A single-payer is sometimes seen as a remedy in the presence of economies of scale (Hurley, 2000). 
ECO/WKP(2010)25

\section{Annex 5.}

\section{Principal component and cluster analysis}

Going beyond the analysis of simple (bilateral) correlations, Principal Component Analysis (PCA) can be used to identify those institutional features which most differentiate OECD countries and to assess empirically how various institutional features are combined across countries. Cluster analysis can be used to group countries with comparable policy settings, i.e. specific combinations of policy instruments.

\section{Principal component analysis (PCA)}

PCA condenses the information contained in a set of indicators into a smaller number of uncorrelated principal components, which are linear combinations of the original indicators. If $X$ is a $(n, p)$ matrix of $\mathrm{n}$ countries and $\mathrm{p}$ indicators, the first principal component (eigenvector) $\mathrm{v}_{1}$ is obtained by maximising the variance explained $\mathrm{v}_{1}{ }^{\prime} \mathrm{X}^{\prime} \mathrm{X} \mathrm{v}_{1}$ under a normalisation constraint $\mathrm{v}_{1}{ }^{\prime} \mathrm{v}_{1}=1$. The second principal component is obtained by maximising $\mathrm{v}_{2}{ }^{\prime} \mathrm{X}^{\prime} \mathrm{X} \mathrm{v}_{2}$ under the normalisation constraint $\mathrm{v}_{2}{ }^{\prime} \mathrm{v}_{2}=1$ and the condition that it is orthogonal to the first principal component $\mathrm{v}_{1}{ }^{\prime} \mathrm{v}_{2}=0$. Other principal components are derived in the same way. One can demonstrate that $\mathrm{v}_{1}$ corresponds to the eigenvector associated with the largest eigenvalue of the covariance matrix $\mathrm{X}^{\prime} \mathrm{X}, \mathrm{V}_{2}$ to the eigenvector associated with the second largest eigenvalue and similarly for the other principal components. The eigenvalues represent the percentage of variance explained by each principal component and the $\mathrm{p}$ elements of the eigenvectors reflect the weights attributed to each indicator in the calculation of principal components (e.g. Table 5 in the main text).

The circle of correlations is a standard way to illustrate the relations between principal components and indicators. The correlation coefficient between indicator $i$ and principal component $j$ is derived as $\sqrt{ } \lambda_{\mathrm{j}} . \mathrm{v}_{\mathrm{ij}} / \sigma_{\mathrm{i}}$, where $\lambda_{\mathrm{j}}$ is the eigenvalue associated with principal component $\mathrm{j}, \mathrm{v}_{\mathrm{ij}}$ the component of eigenvector $\mathrm{j}$ corresponding to variable $\mathrm{i}$ and $\sigma_{\mathrm{i}}$ the standard deviation of variable $i$. These coefficients sometimes referred to as factor loadings - are reported in the correlation circle (e.g. Figure 13, Panel A). The variables which exhibit the strongest correlations with the principal components, and hence have most weight in this analysis, are represented close to the circle. Variables situated in the centre of the circle have little significance on the dimensions identified by the principal components - they are little correlated with most of the other variables.

Country coordinates on principal components can be computed using the relevant eigenvectors $\mathrm{v}_{\mathrm{j}}$ to weight indicator values, showing how countries score relative to each other on the dimensions associated with the axes (e.g. Figure 13, Panel B). 


\section{Cluster analysis}

The cluster analysis carried out in this paper is a hierarchical and agglomerative (bottom-up) classification. The algorithm begins with each country as a separate cluster and successively groups countries into larger clusters, so as to minimise the within-cluster variance (Ward's Minimum-Variance Method). ${ }^{6}$ A tree diagram (Figure A5.1) showing successive clusters provides information on the loss of information resulting from each aggregation, allowing the partition of the sample into groups of countries which share common characteristics on the variables included in the analysis.

The robustness of the clusters identified can be assessed with the approximately unbiased (AU) p-values calculated using the pvclust package (Suzuki and Shimodaira, 2006). The calculation of AU p-values is based on multi-scale bootstrap re-sampling, which is more accurate than the simple bootstrap (Efron et al., 1996; Shimodaira, 2002, 2004). The p-value represents the percentage of occurrence of a given cluster when a large number of bootstrap replications (e.g. 10000$)$ are performed.

6. $\quad$ PCA and cluster analysis are often performed on standardised variables. This is necessary when variables are measured in different units, because non-standardised variables would be assigned weights proportional to their variance. The indicators on health policies and institutions are on the same scale (0 to 6). Standardising the variables would give the same weight to small differences in variables that vary little across countries (e.g. breadth of coverage) and to large variations in variables that vary widely across countries (e.g. gate-keeping). Therefore, PCA and cluster analysis on health policies and institutions have been carried out without prior standardisation of the variables. 
Figure A5.1. Dendogramme

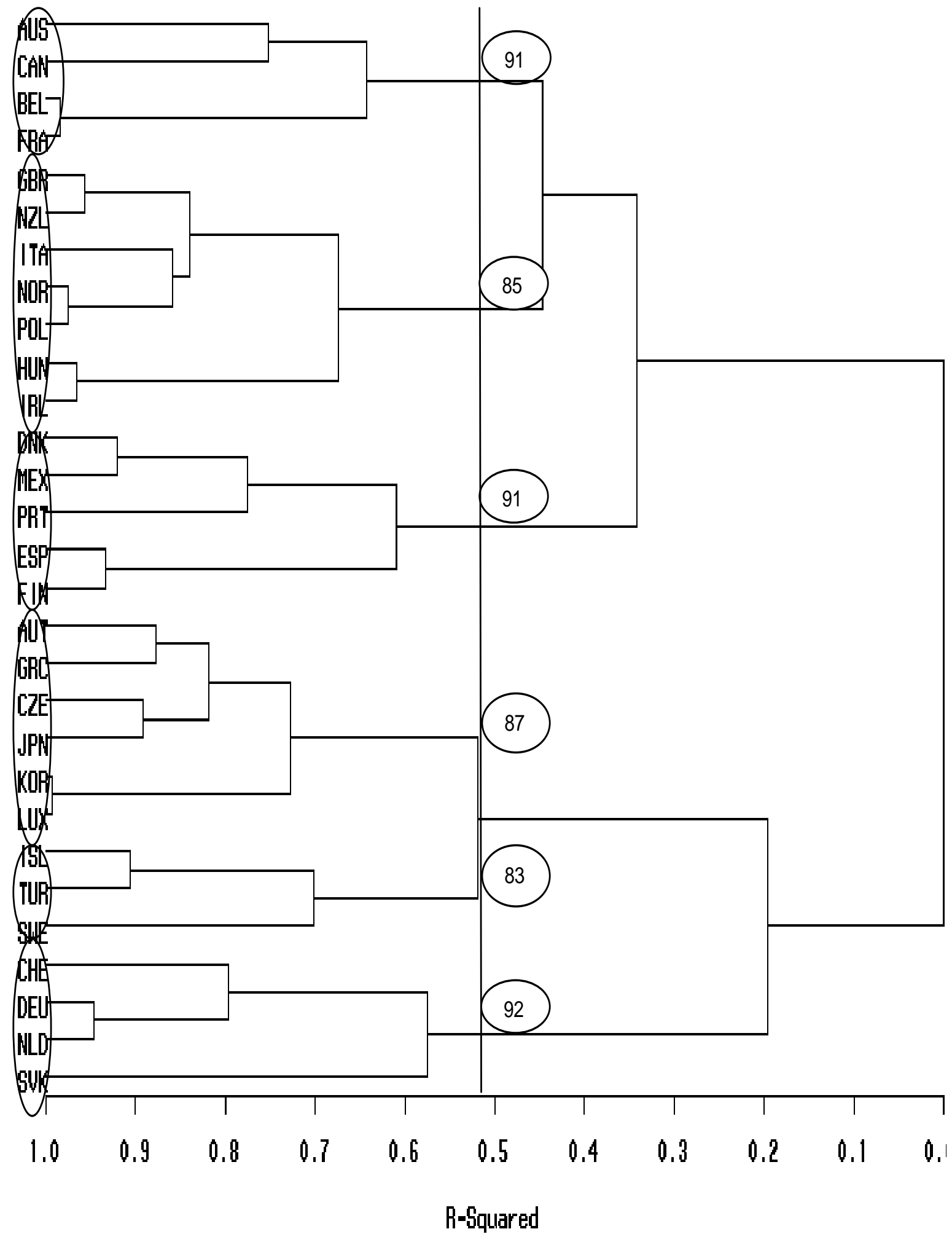

Note: This dendogramme reflects the results of the cluster analysis performed on the twenty institutional indicators (see Figure 9). The R-squared measures the ratio of the between-clusters variance to the total variance of the data. Hence, the reduction in the value of the R-squared resulting from each clustering step can be interpreted as the loss of information caused by the grouping of countries. The numbers in the circles represent the confidence level in percentage associated with each cluster, i.e. the Approximately Unbiased (AU) p-values generated through multiscale bootstrap resampling. 


\section{Annex 6.}

\section{Principal component analysis on budget and management approaches to control public spending}

A principal component analysis (PCA) on the budget and management indicators identifies two main dimensions along which countries can be differentiated. The first one is mainly driven by the intensity of the budget constraint and, negatively correlated with it, the degree of delegation to insurers and consistency in responsibility assignment across levels of governments (Table A6.1 and Figure A6.1, Panel A). The countries on the right of the first (horizontal) axis are those where health coverage is mainly managed at the government level, with a tight budget constraint (Figure A6.1, Panel B). Countries where the government has devolved health policy responsibilities to social security or individual insurance funds tend to be on the opposite side of the axis. The second important dimension relates to the degree of decentralisation across levels of governments. Decentralised countries score high on the second (vertical) axis. In most of them, coverage is mainly managed at the government level - i.e. they are situated on the right part of the chart - with Austria and Switzerland standing as exceptions.

Table A6.1. Principal component analysis on budget and management indicators

\begin{tabular}{lrrrr}
\hline & \multicolumn{4}{c}{ Principal components } \\
& \multicolumn{1}{c}{1} & 2 & \multicolumn{1}{c}{3} & \multicolumn{1}{c}{4} \\
\cline { 2 - 5 } Eigenvalue & 5.6 & 3.2 & 2.0 & 1.5 \\
Share of the variance explained (\%) & 39.5 & 22.9 & 14.3 & 10.8 \\
Cumulative share of the variance explained (\%) & 39.5 & 62.5 & 76.8 & 87.6 \\
& & & & \\
Eigenvectors & & & -0.57 & -0.21 \\
Priority setting & 0.06 & 0.02 & -0.07 & 0.21 \\
Budget constraint & 0.75 & 0.55 & 0.76 & -0.34 \\
Regulation of workforce and equipment & 0.17 & -0.09 & 0.14 & 0.08 \\
Regulation of prices paid by third-party payers & 0.00 & 0.19 & -0.05 & 0.48 \\
Decentralisation & 0.36 & -0.75 & -0.05 & -0.12 \\
Delegation & -0.32 & 0.03 & -0.18 & 0.73 \\
Consistency & -0.41 & 0.29 & 0.20 & \\
\hline
\end{tabular}


Figure A6.1. Budget and management approaches to control public spending Results of a principal component analysis

Panel A. Correlation circle ${ }^{1}$

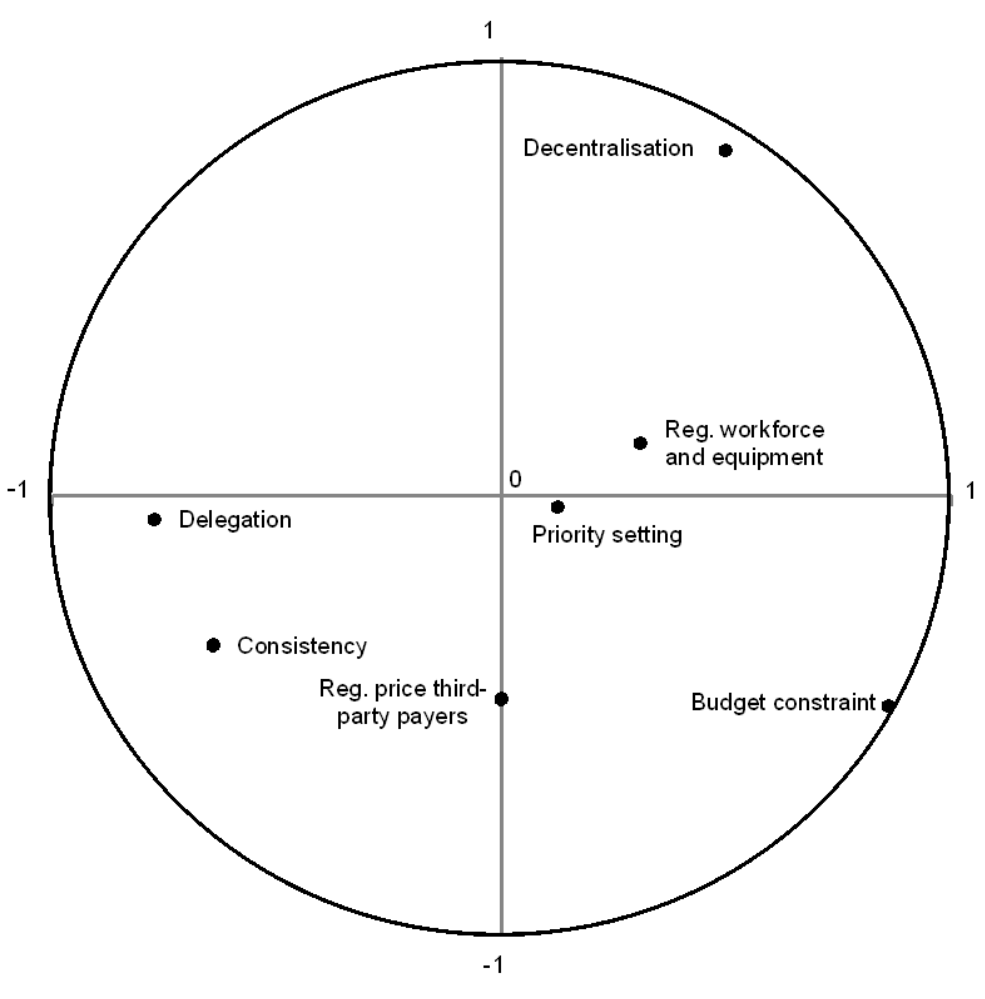

Panel B. Country relative position ${ }^{2}$

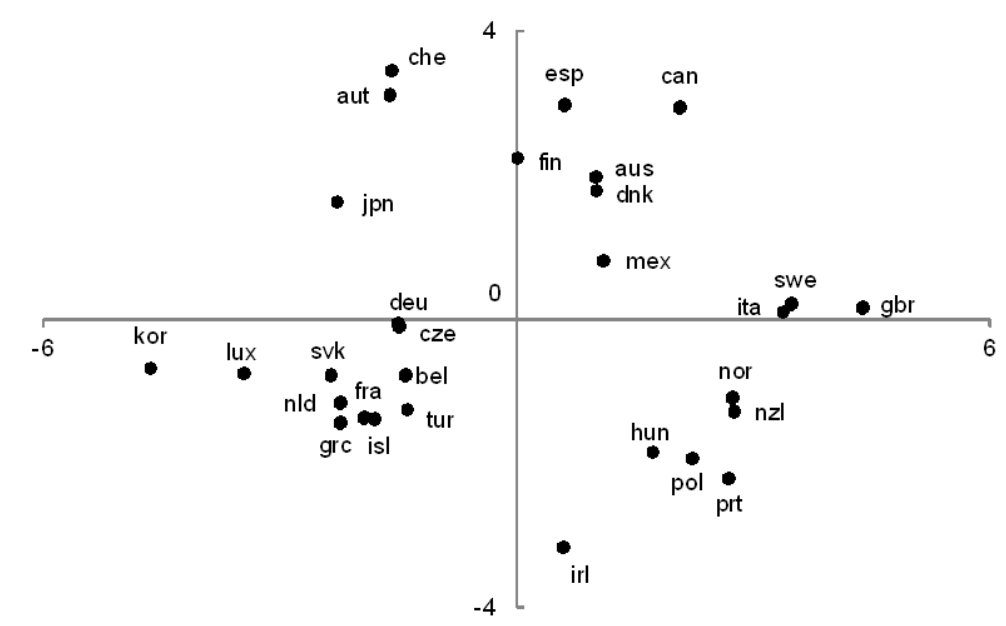

1. The axes of the chart correspond to the first two factors of the PCA, i.e. those that explain the greatest part of the cross-country variance of the policy instruments. The values on the hoizontal (resp. vertical) axis comespond to the correlation coefficients with the first (resp. second) factor of the PCA.

2. The values on the horizontal axis (resp. vertical) comespond to weighted averages of the policy instruments, the weights being determined by the eigenvector associated with the frst (resp. second) factor of the PCA

Source: OECD Survey on Health Systems Characteristics 2008-09. 


\section{Acronyms}

$\begin{array}{ll}\text { ALOS } & \text { Average length of stay } \\ \text { AMI } & \text { Acute myocardial infarction } \\ \text { AU } & \text { Approximately Unbiased } \\ \text { CHF } & \text { Congestive heart failures } \\ \text { COPD } & \text { Chronic obstructive pulmonary diseases } \\ \text { DALE } & \text { Disability Adjusted Life Expectancy } \\ \text { DEA } & \text { Data Envelopment Analysis } \\ \text { DFLE } & \text { Disability-Free Life Expectancy } \\ \text { DRG } & \text { Diagnosis Related Groups } \\ \text { DTP } & \text { Diphtheria, tetanus and pertussis } \\ \text { ESCS } & \text { Index of economic, social and cultural status } \\ \text { GP } & \text { General practitioner } \\ \text { HALE } & \text { Health Adjusted Life Expectancy } \\ \text { HCQI } & \text { Health Care Quality Indicator } \\ \text { HMO } & \text { Health maintenance organisation } \\ \text { MRI } & \text { Magnetic resonance imaging units } \\ \text { NHS } & \text { National Health Service } \\ \text { NICE } & \text { National Institute for Health and Clinical Excellence } \\ \text { OOP } & \text { Out-of-pocket payment } \\ \text { PCA } & \text { Principal Component Analysis } \\ \text { PHIs } & \text { Private health insurance } \\ \text { PYLL } & \text { Potential years of life lost } \\ \text { PISA } & \text { Programme for International Student Assessment } \\ \text { PPP } & \text { Purchasing power parity } \\ \text { QALY } & \text { Quality-adjusted life years } \\ \text { WHO } & \text { World Health Organisation }\end{array}$




\section{WORKING PAPERS}

The full series of Economics Department Working Papers can be consulted at www.oecd.org/eco/workingpapers/

768. The OECD's new global model

(May 2010) by Karine Hervé, Nigel Pain, Pete Richardson, Franck Sédillot and Pierre-Olivier Beffy

767. Assessing the impact of the financial crisis on structural unemployment in OECD countries (May 2010) by Stéphanie Guichard and Elena Rusticelli

766. After the crisis: bringing German public finances back to a sustainable path (April 2010) by Isabell Koske

765. Optimal monetary and fiscal stabilisation policies (May 2010) by Klaus Adam

764. Asset prices and real economic activity (May 2010) by E. Philip Davis

763. Fiscal policy reaction to the cycle in the OECD: Pro- or counter-cyclical? (May 2010) by Balázs Égert

762. New evidence on the private savings offset and Ricardian equivalence (May 2010) by Oliver Röhn

761. Monetary policy reaction functions in the OECD (May 2010) by Douglas Sutherland

760. Counter-cyclical economic policy

(May 2010) by Douglas Sutherland, Peter Hoeller, Balázs Égert and Oliver Röhn

759. Exports and property prices in France: are they connected?

(April 2010) by Balázs Égert and Rafał Kierzenkowski

758. Further Advancing Pro-Growth Tax and Benefit Reform in the Czech Republic (April 2010) by Zdeněk Hrdlička, Margaret Morgan, David Prušvic, William Tompson and Laura Vartia.

757. Advancing structural reforms in OECD countries: Lessons from twenty case studies (April 2010) by William Tompson and Thai-Thanh Dang

756. Labour markets and the crisis (April 2010)

755. Long-term growth and policy challenges in the large emerging economies (March 2010) by Paul Conway, Sean Dougherty and Artur Radziwill

754. Explaining household saving rates in $G 7$ countries: implications for Germany (February 2010) by Felix Hüfner and Isabell Koske 
753. Monetary policy responses to the crisis and exit strategies (February 2010) by Makoto Minegishi and Boris Cournède

752. Sub-central governments and the economic crisis: impact and policy responses (February 2010) by Hansjörg Blöchliger, Claire Charbit, José Maria Pinero Campos and Camila Vammalle

751. Improving China's health care system (January 2010) by Richard Herd, Yu-Wei Hu and Vincent Koen

750. Providing greater old-age security in China (January 2010) by Richard Herd, Yu-Wei Hu and Vincent Koen

749. China's labour market in transition: job creation, migration and regulation (January 2010) by Richard Herd, Vincent Koen and Anders Reutersward

748. A pause in the growth of inequality in China?

(January 2010) by Richard Herd

747. China's financial sector reforms (January 2010) by Richard Herd, Charles Pigott and Sam Hill

746. A bird's eye view of OECD housing markets (January 2010) by Christophe André

745. The automobile industry in and beyond the crisis (January 2010) by David Haugh, Annabelle Mourougane and Olivier Chatal

744 Towards a flexible exchange rate policy in Russia (December 2009) by Roland Beck and Geoff Barnard

743. Fiscal federalism in Belgium: Challenges and possible improvements (December 2009) by Willi Leibfritz

742. Product Market Regulation in Russia (December 2009) by Paul Conway, Tatiana Lysenko and Geoff Barnard

741. How to reform the Belgian tax system to enhance economic growth (December 2009) by Jens Høj

740. Improving the policy framework in Japan to address climate change (December 2009) by Randall S. Jones and Byungseo Yoo

739. Health-care reform in Japan: controlling costs, improving quality and ensuring equity (December 2009) by Randall S. Jones

738. Financial stability: overcoming the crisis and improving the efficiency of the banking sector in Japan (December 2009) by Randall S. Jones and Masahiko Tsutsumi 